\title{
unipress
}

Interfacing Science, Literature, and the Humanities / ACUME 2 Vol. 5 Anneke Smelik (ed.)

\section{The Scientific Imaginary in Visual Culture}

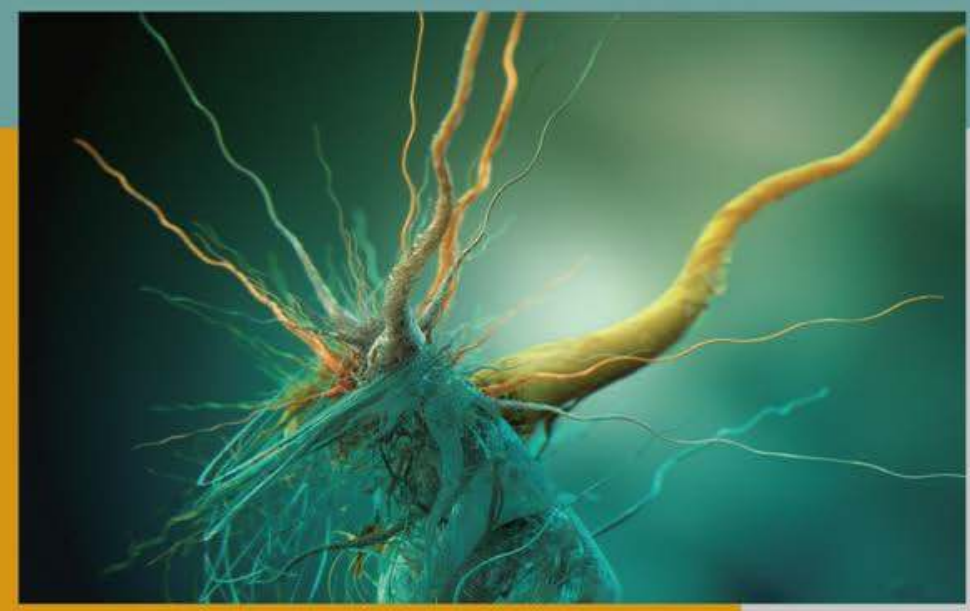




\section{VধRunipress}

Open-Access-Publikation im Sinne der CC-Lizenz BY-NC-ND 4.0

(C) 2010, V\&R unipress GmbH, Göttingen 


\title{
Interfacing Science, Literature, and the Humanities / ACUME 2
}

\author{
Volume 5
}

Edited by

Vita Fortunati, Università di Bologna

Elena Agazzi, Università di Bergamo

Scientific Board

Andrea Battistini (Università di Bologna), Jean Bessière (Université Paris III -

Sorbonne Nouvelle), Dino Buzzetti (Università di Bologna), Gilberto Corbellini

(Università di Roma »La Sapienza«), Theo D’Haen (Katholieke Universiteit

Leuven), Claudio Franceschi (Università di Bologna), Brian Hurwitz (King's

College, London), Moustapha Kassem (Odense Universiteit, Denmark), Tom

Kirkwood (University of Newcastle), Ansgar Nünning (Justus Liebig Universität

Gießen), Giuliano Pancaldi (Università di Bologna), Manfred Pfister (Freie

Universität Berlin), Stefano Poggi (Università di Firenze), Martin Prochazka

(Univerzita Karlova v Praze), Maeve Rea (Queen's College, Belfast), Ewa Sikora

(Nencki Institute of Experimental Biology, Warszawa), Paola Spinozzi

(Università di Ferrara)

Editorial Board

Kirsten Dickhaut (Justus Liebig Universität Gießen), Raul Calzoni (Università di Bergamo), Gilberta Golinelli (Università di Bologna), Andrea Grignolio

(Università di Bologna), Pierfrancesco Lostia (Università di Bologna) 
Anneke Smelik (ed.)

\section{The Scientific Imaginary in Visual Culture}

With 17 figures

\section{V\&R unipress}



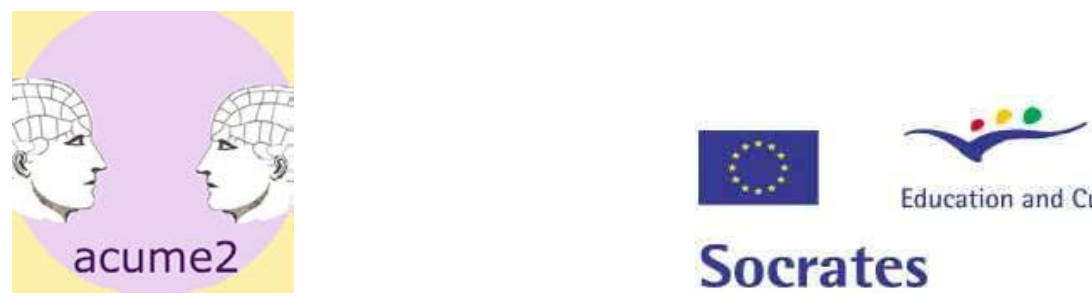

Education and Culture

\section{Socrates}

This book has been published with the support of the Socrates Erasmus program for Thematic Network Projects through grant 227942-CP-1-2006-1-IT-ERASMUS-TN2006-2371/001-001 SO223RETH.

This project has been funded with support from the European Commission. This publication reflects the views only of the author and the Commission cannot be held responsible for any use which might be made of the information contained therein.

Questo volume è stato pubblicato con il contributo del programma Socrates Erasmus per i progetti di reti tematiche - 227942-CP-1-2006-1-IT-ERASMUS-TN2006-2371/001-001 SO2-23RETH.

Il progetto è stato finanziato con il contributo della Commissione europea.

La presente pubblicazione riflette le idee del solo autore e la Commissione europea non può ritenersi responsabile per l'uso che potrebbe essere fatto delle informazioni contenute al suo interno.

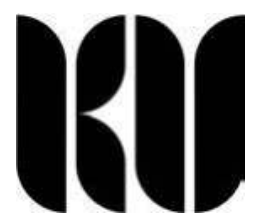

An electronic version of this book is freely available, thanks to the support of libraries working with Knowledge Unlatched. KU is a collaborative initiative designed to make high quality books Open Access for the public good. The Open Access ISBN of this book is 978-3-86234-756-8. More information about the initiative and links to the Open Access version can be found at www.knowledgeunlatched.org.

Bibliographic information published by the Deutsche Nationalbibliothek

The Deutsche Nationalbibliothek lists this publication in the Deutsche Nationalbibliografie; detailed bibliographic data are available in the Internet at http://dnb.d-nb.de.

\section{ISBN 978-3-86234-756-8}

(C) Copyright 2010 by V\&R unipress GmbH, D-37079 Goettingen

This publication is licensed under a Creative Commons Attribution-Non Commercial-

No Derivatives 4.0 International license, at DOI 10.14220/9783862347568. For a copy of this

license go to https://creativecommons.org/licenses/by-nc-nd/4.0/.

Any use in cases other than those permitted by this license requires the prior written permission from the publisher.

Cover image: 'Growth of Cubic Bacteria', 2008, @ by Vaclav Pajkrt, reproduced with the kind permission of the artist. 


\section{Contents}

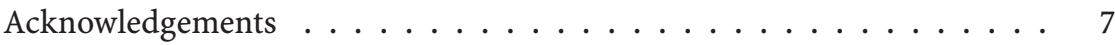

Anneke Smelik

Introduction - The Scientific Imaginary in Visual Culture $\ldots \ldots \ldots 9$

\section{Part I: History and Philosophy}

Robert Zwijnenberg

Chapter 1: How to Depict Life: A Short History of the Imagination of

Human Interiority $\ldots \ldots \ldots \ldots . \ldots \ldots$

Matteo Merzagora

Chapter 2: Reflecting Imaginaries: Science and Society in the Movies _. 39

Katia Pizzi

Chapter 3: Reappraising Futurist Mechanical Art $\ldots \ldots \ldots$. . . . 53

\section{Philosophical Interlude}

Rosi Braidotti

Chapter 4: The Posthuman Predicament . . . . . . . . . . . . 69

\section{Part II: Media}

Anneke Smelik

Chapter 5: Cinematic Fantasies of Becoming-Cyborg _ . . . . . . . 89

Paolo Granata

Chapter 6: Video ergo sum: Video Art as Symbolic Form . . . . . . . 105

Michel van Dartel

Chapter 7: Enactive Media: A Dialogue between Psychology and Art ‥ 117 
Edyta Just

Chapter 8: The Positive Potential of IVF in Visual Culture . . . . . . . 133

\section{Part III: Bioart}

Aline Ferreira

Chapter 9: Our Cells/Our Selves: Sexual Politics in Bioart . . . . . . . . . 149

\section{Trish Adams}

Chapter 10: Exploring Mixed Realities and Scientific Visualisations in Art/Science Collaborations . . . . . . . . . . . . . . . 163

Catherine Fargher and Terumi Narushima

Chapter 11: Knit Two Together: Art/ Science Collaborations in BioHome. The Chromosome Knitting Project . . . . . . . . . . . . . 181

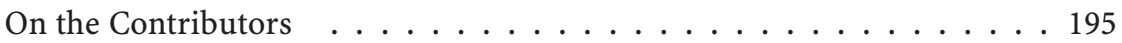




\section{Acknowledgements}

The Scientific Imaginary in Visual Culture is one of the outcomes of the European Thematic Network ACUME 2, "Interfacing Science, Literature and Humanities: an Interdisciplinary Approach", that was run from 2006 till 2009, and funded by the European Commission. The network could not have been successful without the creative and productive coordination by professor Vita Fortunati from the University of Bologna. I want to express my gratitude for her inspiring leadership and unceasing support, both intellectually and financially. The book is the direct output of the subgroup "The Human and the Posthuman". I want to thank the coordinators Brian Hurwitz, Max Saunders, Paola Spinozzi and Giorgio Turchetti for the exciting discussions in the workshops and conferences that they put together. This book is indebted to the intellectual contribution of all the participants, many of whom became an author of one of its chapters.

My invaluable research assistant Maarten Michielse helped to produce the book in its final stages, with his unfailing eye for detail and trustworthy account of the digital archives. I also want to thank Joyce Scheeren for her help in finalising the manuscript. Finally, I wish to thank the artist Vaclav Pajkrt for his kind permission to reproduce one of his wonderful bioart works for the cover of the book.

Every effort has been made to trace rights holders, but if any have been inadvertently overlooked the publisher would be pleased to make the necessary arrangements at the first opportunity. 
Open-Access-Publikation im Sinne der CC-Lizenz BY-NC-ND 4.0 (C) 2010, V\&R unipress GmbH, Göttingen 


\section{Introduction - The Scientific Imaginary in Visual Culture}

The volume The Scientific Imaginary in Visual Culture explores the ways in which visual culture represents and remediates science. The 'scientific imaginary' that is set out in the title of the book indicates that science has profound effects upon the imagination, and conversely, of the imagination in and upon science. Popular media, art and science have become intricately interlinked in contemporary visual culture. The development of new 'mediascapes' calls for an analysis of the ways in which visual culture and science interface. The Scientific Imaginary in Visual Culture is a collection of new essays in the interdisciplinary field of media studies, cultural studies and science and technology studies, exploring the mutual contaminations and hybridisations between visual culture and science.

The close relation between science and visual culture in western modernity has been widely commented upon. John Crary's (1992) seminal book, for example, shows the intersection, convergence and exchange of disciplines ever since the birth of modern science. José van Dijck (2005) explained how the advance of medical sciences was spurred on by visualisation techniques. Galileo Galilei's discoveries were not feasible without the invention of the telescope, just as the realist perspective in Johannes Vermeer's paintings was not possible without his fascination for the camera obscura. Skills of looking and observing belonged as much to the realm of science and technology as to the realm of the arts. Visual culture as we know it today, with its vast array of audiovisual technologies and explosion of images in both the private and public sphere, derived from the concerted effort of artists and philosophers as well as engineers and scientists. In contemporary text books of media studies the term 'visual culture' therefore not only pertains to images in the fine art, popular film and television, advertising or the internet, but also to fields that are often mistakenly thought to be distinct from culture, such as law, medicine and the sciences (Sturken \& Cartwright 2009, 347). Visual culture of today envelops a diverse range of images across previously separated but increasingly blurring disciplines. 
In the course of the last century it has become clear that much of our scientific knowledge actually depends on its representation in visual culture. One of the central points in the debate about the relationship between science and its visual representation was for a long time centred on the issue of 'truth'. The nineteenth century idea that truth is self-evident by visualising an object, gave way to the foucauldian idea that truth is an effect of discourse. The idea that to see is to know and to understand has been with us ever since the time of the Greeks; an idea that Foucault (1963) among others unravelled in his analysis of the construction of the medical gaze and clinical anatomy as an important tool for creating a certain truth in science. The development of a medical and clinical gaze was much helped by new technologies such as X-ray photography that could penetrate the surface and reveal the hidden inside of the body. Where photography and X-ray were easily coded as documenting visual evidence, imaging techniques of today, such as MRI scan, CI scan or PET scan, endoscopy, ultrasound, or computed tomography, require highly trained skills to be read.

While scientific truth may be 'complexified' through postmodern thought, science still holds a huge influence over the visual imaginary. There is, however, a certain equation between visualisation techniques and scientific truths, in the sense that in visual culture of today hierarchies may have been turned around and scientific images do not spell out a self-evident truth any longer. Postmodern culture has the effect of flattening out hierarchical differences between images, collapsing borders between science and popular media, and undoing strict boundaries between fact and fiction. In a witty and complicated argument that I cannot do justice to in this short introduction, W.J.T. Mitchell even claims that "images are like living organisms" (Mitchell, 2005, 11). At the same time artists increasingly engage with science in a growing body of artworks that does engage with 'real' living organisms, under the name of 'bio-art', 'sci-art', 'geneti-art' or the like. The postmodern turnover of hierarchies and the contemporary mutual engagement between art and science may pull together those two fields after they had radically diverged in the nineteenth century. The 'third culture' that C.P. Snow (1959) envisaged for the future may be closer than he imagined in his famous essay on 'the two cultures' of art and science. As Sian Ede points out, scientists talk more about 'beauty' than artists do today (Ede 2005, 1). She also claims that the public is better informed about contemporary science than it is about contemporary art. The question therefore shifts perhaps from issues of truth and evidence to issues of beauty and affect.

The Scientific Imaginary in Visual Culture not only addresses how visual represesentations of science persuade, move, worry or affect us, but also raises critical and ethical issues about contemporary science. The recurrent issues that surface time and again in the scientific imaginary in visual culture can be ranged in three categories: structures and processes of the human mind and body; new 
technologies in science; and ethical controversies (see also Ede 2005, 3). These elements return in many of the chapters of this book. To take just a few examples, the question of human mind and body return in the experience of video art and in experiments with perception in new media (chapters 6 and 7), as well as in the pervasive figure of the cyborg (chapter 5). Science's new technologies are discussed in the last three chapters of the book on experimental bioart as well as in the popular imagination in the movies (chapter 3). Ethical controversies are raised in the historical account of the imagination of human interiority (chapter 1), in the political aspirations of Futurism (chapter 3), in the critical discussion of the posthuman (chapter 4) and in the medical practice of in vitro fertilisation (chapter 8). This is by no means an exhaustive account, because in fact the three categories are not neatly distributed across the chapters and may often overlap and intertwine throughout the case studies that are discussed. The book thus presents a critical study of certain ways in which diverse cultural practices mediate scientific ideas and discourses.

The volume starts with a historical account of the scientific imaginary in visual culture, from representations of the human body in art and science, to cinematic or artistic representations of science and technology. Ever since scientific developments in genetics, information technology and cybernetics open up new possibilities of intervention in human lives, cultural theorists have explored the notion of the 'posthuman' (Hayles 1999). In a philosophical interlude the book re-traces the origins of the concept of the 'human' and opens up to the critical notion of the posthuman as a way to move towards a sustainable future. In the second part of the book several authors analyse figurations of the 'posthuman' in media and genres such as science fiction, 'videomorphic' culture, digital (or rather 'enactive') media and in scientific practices. Sometimes, the posthuman is figured as an uncanny 'other' and sometimes as an ethical imperative to a different kind of experience, perception or affect. The third part of the volume explores the relatively new phenomenon of 'bioart'. Through an engagement with scientific and technological developments, the bioartists address ethical issues that are either dominated or ignored by the sciences. From the chapters the reader will certainly get the idea that visual culture of today not only celebrates science but also exposes the scientific illusion of the ultimate mastery of life (cf. Mitchell 2005, 334).

The essays together interrogate the ways in which visual culture and science interface by using interdisciplinary methodologies. The blurring of boundaries between human/machine, nature/culture, technology/organism, sex/gender, heralded by the figuration of the cyborg (Haraway 1991), constitutes a theoretical point of departure for this book. The researchers question the idea of 'humanness' in a posthuman or even postnatural world. Many examples from visual culture and art show the permeable boundaries between art and science, 
and the authors engage likewise with current scientific and technological concerns. This volume highlights the search for tools and theories by which we can effectively analyse the complex interplay between textual, visual, imaginary, technological and biological dimensions of science and of the scientific imaginary.

\section{Part I: History and Philosophy}

The Scientific Imaginary in Visual Culture opens with three essays that provide a historical background to representations of science in Western culture, ranging from the fine arts in classical times, to popular cinema, to modern and postmodern art of today.

In the first chapter, Robert Zwijnenberg compares three historical moments of our knowledge of the human body's interior: first, the anatomical opening of our body's interior from the fourteenth century onwards and the depiction of human interiority in anatomical drawings and prints, by for example Vigevano, Da Vinci and Rembrandt; second, the representation of the body's interior by means of medical imaging technologies from the end of the nineteenth century onwards in X-ray technology, endoscopy, ultrasound, CT-scan, MRI-scan, and PET; and, third, the exposure of the interior human body at the cellular level, as it took off in particular in biomedical and genetic research after the Second World War. Zwijnenberg shows that in the early modern period anatomical knowledge was intertwined with broader philosophical and religious views about human life and the human body, which is no longer the case in the second and third phase of imaging physical interiority. In discussing contemporary bioart, such as Susan Aldworth and the Tissue Culture and Art Project, he shows that the philosophical, ethical and cultural implications of life-scientific reflection on life can be uncovered through artistic imagination. In other words, art can be critical about the cultural embedding of new technologies in ways that science itself is not, enabling art to act again as a participant in the public debate on the life sciences. Zwijnenberg argues that such participation by artists is crucial, if we value public discussions on these concerns that are not exclusively guided by life sciences experts.

In the second chapter, Matteo Merzagora gives a historical overview of science as a topic and of scientists as a character in popular cinema, arguing that films have contributed to the shaping of the image of science and scientists among the general public. The main characteristic of scientists on screen is their ambivalence: they are good guys in their desire to understand and improve life, but they become bad guys when they try to master and control the world. The most common plot involving scientists, therefore, concerns an unstable equilibrium 
between knowledge and power. Cinema recognizes that science has the power to both understand and to change the world, and it exploits this double edged power to satisfy its narrative goals. In addition to the classical science fiction topics such as encounters with alien worlds, Hollywood's scientific explorations tend to concentrate on natural catastrophes, man made disasters, manipulation of the living world, creation of artificial beings or intelligence, the relation between science and war (in particular the atomic bomb). Merzagora argues that these are the kind of topics where science can feature in its Jekyll and Hyde's suit: ambivalent and controversial. Science as portrayed in popular films is not a representation of real science, nor are popular films a faithful mirror of science in society. Cinema, therefore, reflects, constructs, and influences public perception of science and the interrelationships between science and society at large.

In the third chapter, Katia Pizzi, takes us back to the Italian Futurists and their indiscriminate endorsement of the machine, as laid down in the Manifesto of Futurism in 1909 by Marinetti. Pizzi explores how the movement of Futurism proposed and pursued an original aesthetic re-thinking of artistic practice, hinging on the contamination and hybridisation between visual, textual and scientific discourses. She does so by comparing the prominent figure of Marinetti to the lesser known artists Paladini and Pannaggi of the post-war Futurist avant-garde. Pizzi shows that these two artists both devised and circulated a lucid conceptualisation of machine aesthetics that was much more persuasive than Marinetti's own hackneyed reflections on machines. She claims that Marinetti's Promethean, fetishised, and sexualised machines failed to acknowledge the machine's social and economic reality. In her view, Marinetti does not resolve the relationship between man and machine, because he remains trapped in a prose that is redolent of sexual attraction and betrays latent fear and alienation. Instead, Pizzi argues that Pannaggi and Paladini's stance is in fact socially and politically embedded, and therefore heralds far more convincing and enduring cyborg alliances.

\section{Philosophical Interlude}

After the historical background in the first part of the volume, Rosi Braidotti gives the reader the necessary philosophical background to the notion of the 'posthuman'. This will help to set the philosophical grounding for parts II and III about contemporary practices in the visual cultures of media and bioart.

In the fourth chapter, Braidotti first offers a historical context for discourses on the posthuman. She discusses the poststructuralist critique of humanism, which denounces the view of the human subject as rational, autonomous, co- 
herent and endowed with self-consciousness. In spite of this poststructuralist attack on the human subject, Braidotti shows that certain forms of humanism lingered on, for example in its masculinist and eurocentrist perspectives, which needed to be undone by feminism, postcolonialism and anti-racism. In the context of the dominance of science and technology, however, another form of humanism is more relevant, and that is its persistent anthropocentrism. Braidotti argues that in the scientific imaginary of today the human has become posthuman, because biotechnologies, genetic engineering, and information and communication technologies have collapsed the boundaries between animals, vegetables, humans and machines. An anthropocentric view of the human can therefore no longer be maintained. This throws open the self-other relationship and demands a new ethics, which for Braidotti involves a return to the materiality of the body and the primacy of life itself. Only a bio-egalitarian perspective can lead to the social and ecological sustainability of the technologically and scientifically mediated world in which we live. Thus, Braidotti calls for an "embodied and embedded" accountability of the posthuman that we have become, embracing all that lives.

\section{Part II: Media}

The second part of The Scientific Imaginary in Visual Culture collects essays on the ways in which different kind of media represent and remediate science, ranging from science fiction movies, video art, 'enactive' digital technologies, to medical practices.

In the fifth chapter, Anneke Smelik, explores one of the prevailing figurations in a culture dominated by science and technology: the man-machine or the cyborg, a cybernetic organism. Starting from popular images of the cyborg in car commercials and videoclips, she traces the figuration of the hardware, software and wetware cyborg in Sci-Fi movies in the past few decades. While cinema may originally have seen science and technology as potentially threatening, for example in the figure of the mad scientist producing an evil cyborg, or machines as enslavers rather than liberators, Smelik claims that the cyborg is now no longer a figure that instils fear or anxiety. Instead, the figure of the cyborg points to deep-seated desires of posthuman men and women of today to fuse with science, machines and technologies. This is not only apparent in the popularity of the cyborg in visual culture, but also in cultural practices of enhancing and altering the human body, like in the military, sports, fitness and cosmetic surgery. Smelik therefore concludes that human beings of the twenty-first century take control of their own destinies by entering intimate relationships with the machines that they build and construct. The scientific imaginary has thus 
stimulated the self-fashioning of men and women as cyborgs, not only in popular cinema but also in everyday life.

In the sixth chapter, Paolo Granata looks at video art as the symbolic form that is best suited to represent a quintessential stylistic moment of the current scientific and technological imagination. He compares the perspective culture of modern age to the 'videomorphic' culture of the contemporary, postmodern, age. The process he calls videomorphosis is the result of the convergence of technologies of vision that were conceived over the ages, including the latest image processing technologies. Video art thus seems to re-run in slow motion many phenomena of contemporary visual culture. Granata argues that postmodern culture has replaced the perspective vision of the Renaissance with videomorphic vision, implying an involvement of the entire perceptive system. The manifold expressions in video art and video installations reveal the synaesthetic vocation of videomorphosis, reconnecting the sensorial - visual, sound, tactile - component of the aesthetic experience to the super-sensory, or cognitive, realm of ideas. As such, Granata argues, video art points to the continuing process of constituting contemporary man's Weltanschauung in a culture governed by visual technologies.

In the seventh chapter, Michel van Dartel continues a similar line of investigation by discussing new media applications, so-called 'enactive media', where the viewers become active users and the user's body is designated an active role in the media experience. Van Dartel claims that enactive media art is of particular relevance to a revised psychology of perception, which is based on the idea that a perceiver 'enacts' perceptual experiences, in other words, that perceptions are not mere passive processes but enactive actions. Enactive media artworks illustrate how the principle of enactive, or sensorimotor, coordination of the body, shapes our perception of new media. In a complex interaction between media art and psychology, he shows how some instances of media art allow for the remediation of recent theory of perception through art, while this same theory in turn opens up new horizons for artistic exploration. Enactive media thus do not only offer new directions for scientific research, but also new possibilities for artistic exploration through theoretical insight. A dialogue between the scientific discipline of psychology and the visual culture of 'enactive media' can connect body and media in new ways, remediate theory accumulated in the enactive approach, and also create new media art experiences. Therefore, Van Dartel strongly advocates a mutually beneficial dialogue between psychologists studying the enactive approach and media artists pursuing an enactive artwork.

In the eighth chapter we move from media to the medical practice of IVF, in vitro fertilisation. Edyta Just examines human-technology encounters in the practice of IVF, based on empirical data from interviews with IVF-patients and an analysis of visual representations of IVF procedures on the Internet. She 
shows that in visual culture the human body and technology are approached as two ontologically different, and radically opposite units, repeating the binary oppositions that are so prevalent in western culture. The modes of convergence that occur between visual culture and science can therefore not be assessed as positive. Using a deleuzean framework, Edyta Just argues that it is crucial to conceptualise human-technology interactions differently, allowing for an affirmative approach of human-technology encounters in terms of productive cooperation rather than in terms of defeat or surrender. To understand such cooperation as affirmative and productive, or in her words, as a space of transformative becoming, enables us to see that the interaction between the human body and its technological surrounding can be one of experiment and possibility rather than danger and stagnation. Thus, Just argues, we can leave behind the euphoria or melancholia of binary oppositions and instead engage with an empowered view of the human body in its affirmative relation to technology.

\section{Part III: Bioart}

The third and last part of the volume The Scientific Imaginary in Visual Culture opens up the more recent terrain of 'bioart'; the nexus between art and the 'wet' life sciences. Some of those projects involve collaborations between artists and scientists, experimenting with interdisciplinary and potentially transgressive methodologies. Bioart often focuses on a cultural critique of the genetically engineered human and implications of biomedical engineering. The bioartists that are discussed or presented in this book, Helen Chadwick, Julia Reodica, and of course Trish Adams, Catherine Fargher and Terumi Narushima, develop innovative modes of creative practice as they attempt to find new meanings in a posthuman or even postnatural environment.

In the ninth chapter, Aline Ferreira, explores how the artist and the scientist have increasingly come to inhabit contiguous or overlapping aesthetic and epistemological spaces. She concentrates on two different developments within bioart: the turn inwards of versions of self-portraiture, which emphasize the genetic decoding of one's genome, and the visibility conferred on the hymen and the placenta, female organs or membranes that function as thresholds. Issues of visibility and invisibility are thus central to the artworks that she discusses: Helen Chadwick's One Flesh and Viral Landscapes, and Julia Reodica's The hymNext Project. Ferreira argues that these bioartworks can be regarded as alternative attempts at self-portraiture, drawing as they do on the artists' cells, in an effort to reflect on the nature of identity and the increasingly permeable boundaries of the body. The artists explore the space beneath the skin, the occluded interiority of bodies, bringing to light organic elements traditionally 
not seen in such configurations. At the same time, the bioartworks make visible what has traditionally been hidden, such as the placenta and the hymen, opening up a 'matrixial gaze' that undoes the overriding male gaze. The turning inward to the body, away from external appearances, reflects a scientific and genetic imaginary reminiscent of a paradigm shift that took place in the last decades of the twentieth century. According to Ferreira, this cellular imaginary and poetics goes to the heart of contemporary biological developments suggesting that to a great extent we are defined by our DNA.

The last two chapters of the book are written by two Australian artist/researchers, who are creators and practitioners of bioart. In the tenth chapter, Trish Adams reinterprets scientific image data from the perspective of a visual artist and recontextualises contemporary biomedical research in interactive art installations. Adams explores the visual complexities and effects of developing technologies on both art and science, and the emergence of hybridisations and productive cross-disciplinary outcomes. In her essay she discusses two of her own experimental art/science projects, machina carnis and mellifera. Both mixed reality projects speculate on the effects that the convergent and divergent elements of art and science have on concepts of the natural and the artificial as well as objectivity and subjectivity. Adams probes the role of interactivity in new media art, through the interplay between the real-time installations, remote Internet access and virtual environments. Expanding upon the sites of exchange between digital technologies and the ambiguity of data flow and bodily 'presence', the artist/researcher questions contemporary notions of virtual identities and mixed realities. The developing relational systems that evolved during these projects suggest to her that the term 'corporeality' encompasses more than just a biological definition, and should instead be embedded within a wider network of notions of living and non-living and constructions of 'human' and 'posthuman'.

In the eleventh and last chapter, performer Catherine Fargher and musician Terumi Narushima present their installation BioHome: The Chromosome Knitting Project. This is a hybrid performance/installation incorporating live wet biology practices in a contemporary biotech display home. The artwork features video, interactive sound, live theatre and text to explore reproductive futures and biotechnologies. It was developed to exist in a range of contexts, such as scientific laboratories, conferences, galleries and museums, as well as theatrical and performance contexts. By 'wet biology' the artists refer to their work with live plant or animal material, including genetic modification of organisms as well as the creation of bio-products such as DNA fibres and live cell cultures. In the BioHome project they have tried to present this science live, rather than merely represent it through a mediated form. Previously, these technologies had been used by visual and installation artists under the label of 'bioart', but they have been rarely presented in a performance context. The artists therefore 
suggest to label this new form of performance as 'bio-performance'. In the case of BioHome, scientific concepts of evolution, mutation and hybridity influenced the form and content of the work. As a hybrid art form, the BioHome project shows how the meeting of science, technology and art produces creative chances for all involved.

The essays gathered here in the volume The Scientific Imaginary in Visual Culture testify to the liveliness of the interdisciplinary fields of media studies, cultural studies and science and technology studies. On the one hand, the writers highlight the possible promise of the modes of convergence that are emerging both within the fields of visual culture and science and between those two fields. On the other hand, the authors develop ethical and cultural reflections on new developments in science and its visualisation techniques. In that balancing act, the authors have tried to look for the sustainable connections between the human or rather the posthuman and their multiple others in a globalised world that is increasingly infused by technology and science.

\section{Bibliography}

Crary, J. 1992. Techniques of the Observer: On Vision and Modernity in the 19th Century. Cambridge: MIT Press.

Ede, S. 2005. Art and Science. London \& New York: I.B. Tauris.

Foucault, M. 1963. Naissance de la Clinique. Paris: Presses Universitaires de France.

Haraway, D. 1991 [1985]. A Manifesto for Cyborgs: Science, Technology, and Socialist Feminism in the 1980s. Reprinted in Simians, Cyborgs, and Women: The Reinvention of Nature, D. Haraway, 149-81. London: Free Association Books.

Hayles, K. 1999. How We Became Posthuman. Virtual Bodies in Cybernetics, Literature, and Informatics. Chicago and London: The University of Chicago Press.

Mitchell, W.J.T. 2005. What Do Pictures Want? Chicago: The University of Chicago Press. Snow, C.P. 1959. The Two Cultures. Cambridge: Cambridge University Press.

Sturken, M. \& Cartwright, L. 2009. Practices of Looking. An Introduction to Visual Culture. $2^{\text {nd }}$ ed. Oxford \& New York: Oxford University Press.

Van Dijck, J. 2005. Transparent Bodies. A Cultural Analysis of Medical Imaging. Seattle: University of Washington Press. 


\section{Part I: History and Philosophy}


Open-Access-Publikation im Sinne der CC-Lizenz BY-NC-ND 4.0 (C) 2010, V\&R unipress GmbH, Göttingen 


\section{Robert Zwijnenberg}

\section{Chapter 1: How to Depict Life: A Short History of the Imagination of Human Interiority}

\section{Introduction}

In anatomical images from the early-modern period anatomical knowledge is always interlaced with broader natural philosophical and religious views about human life and the human body. Since the late nineteenth century, however, such a wider philosophical and religious angle is no longer visible in scientific representations of the human body or life at the cellular level. This has to do with changing views on science, but also with the emergence of new medical imaging technologies that rendered the work of the anatomical draughtsman superfluous.

This is evident right away when we look at two images of life, an early-modern one and a contemporary one. The first image is a drawing from Vigevano's Anathomia from 1345 (Fig. 1.1). The second image, from our own time, is a micrograph of a human embryonic stem cell (Fig. 1.2). The differences between the two images are immediately apparent, not only in style but also with respect to the techniques with which they were produced. The fourteenth century drawing was made by hand by an individual, while the twenty-first century depiction of the stem cell is a machine-produced image. Although both images depict life, Vigevano's drawing primarily reflects a specific historical-cultural perception of life, in which anatomical knowledge plays an integral role. The stem cell image, on the contrary, primarily reflects a scientific perception of life, and as such the image implies a certain scientific knowledge and view of life.

The more philosophical questions concerning life are not intrinsic to the image, but are situated in its cultural context. Where Vigevano's drawing suggests a philosophical, ethical and religious dimension linked to early-modern anatomical knowledge, such a dimension is absent in the stem cell image. In this essay I will explore in more detail the question of what it means to us and to our culture that scientific images of life - whether at the cellular level or that of the human body - no longer express or invoke a broader cultural perception of life. I will then go on to show how this dimension, which has disappeared from con- 


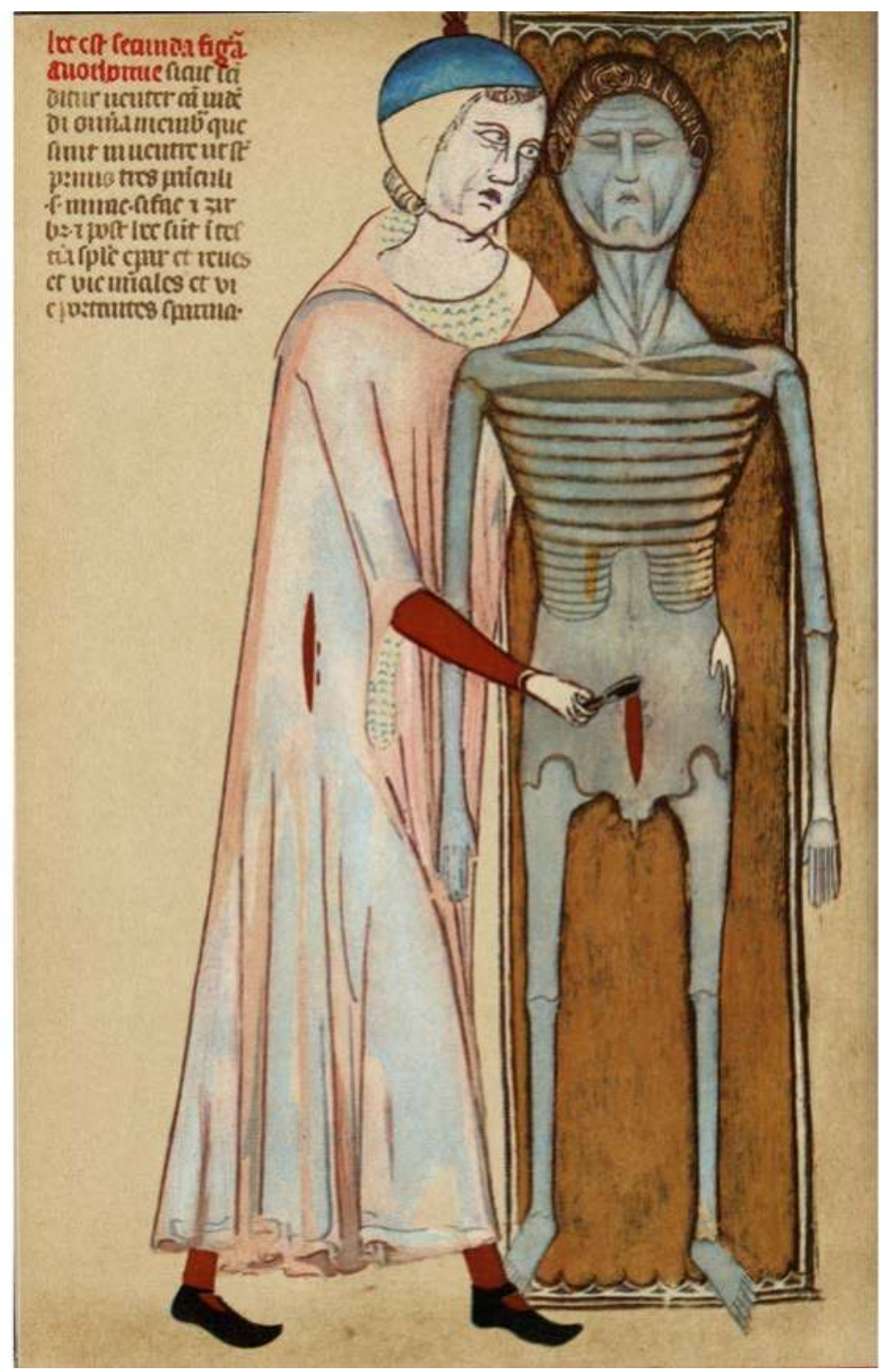

Figure 1.1: Vigevano, Anathomia, 1345. Courtesy Kunsthistorisch Instituut Amsterdam.

temporary scientific representations, is still represented by contemporary artists who work with such images.

Before I do so, I want to briefly clarify the thesis of my essay. There are three important historical moments in the development of our knowledge of the human body's interior: first, the anatomical opening of the body's interior from the fourteenth century onwards, and the depiction of human interiority in 


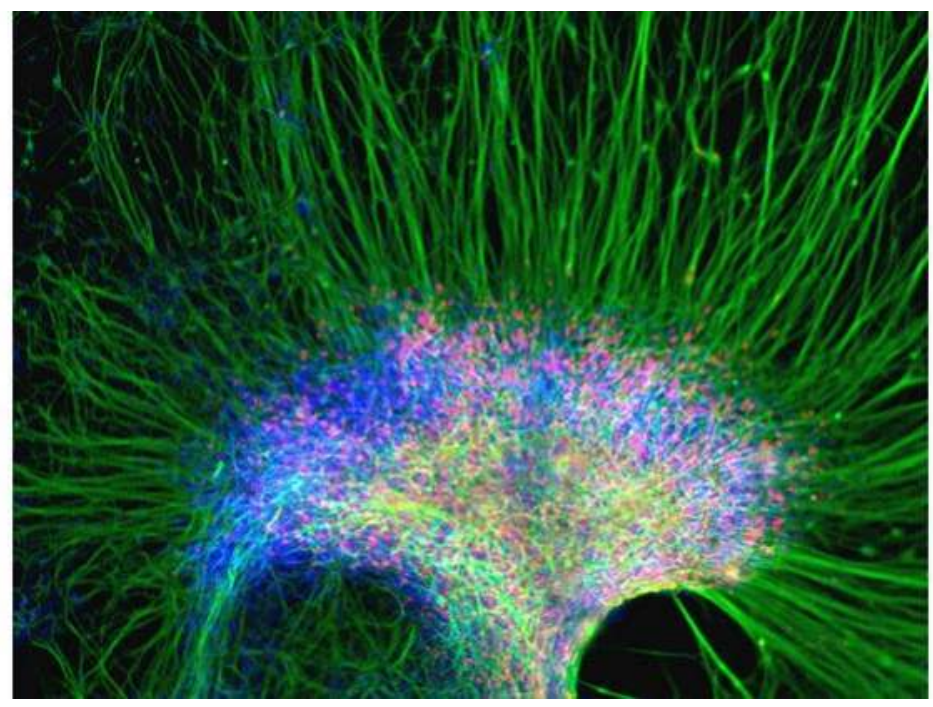

Figure 1.2: A cluster of neural cells were derived from human embryonic stem cells in the lab of UW-Madison stem cell researcher and neurodevelopmental biologist Su-Chun Zhang. Courtesy Su-Chun Zhang.

anatomical drawings and prints; second, the representation of the body's interior by means of medical imaging technologies from the end of the nineteenth century onwards (X-rays, MRI, etc); and, third, the exposure of the interior human body at the cellular level, as it took off in particular in biomedical and genetic research after the Second World War.

In the first period, the cultural embedding of new anatomical knowledge was structurally ensured by the close collaboration between artists and anatomists, as I will illustrate below by analysing a painting by Rembrandt. As a result of the increasing development of art and medical science as two separate domains since the late nineteenth century, however, the emotional complexity has vanished from medical images. This loss not only had a negative effect on the cultural embedding of new medical knowledge of the human body's interior, but it has also brought about a growing gap between medical science and society. Today, as a result of the technological exposure of the interior human body at the cellular level, this cultural embedding is realized no longer - as it was in the early-modern period - in close interaction and collaboration with the arts. The separation between art and science has drastic implications for the evaluation of the ethical implications of new biomedical and genetic knowledge. If we value the significance of a broad and sustained public debate on the ethical implications of new knowledge produced by the life sciences, I want to argue that 
the scientific representation of the body's interior, even at the cellular level, needs artistic imagination. In my view, science cannot do without art.

\section{Vigevano's Anatomy}

The practice of dissecting the human body emerged around $300 \mathrm{BC}$ among Greek anatomists and vanished again around $30 \mathrm{BC}$. Only toward the end of the thirteenth century would the human body be taken up again as a subject of anatomical research at Italian universities, in particular in Bologna. In the course of the fourteenth century anatomical dissection became a regular subject of medical education at Italian universities. Guido da Vigevano (1280-1349) belonged to the first generation of anatomists who once again started practicing the art of opening up the human body. Vigevano was among the first to depict the dissected body in a standing position. This became a standard feature in anatomical illustration (including the work by Vesalius). His drawing shows a rather strange and pathetic scene. As such it hardly seems to represent an actual dissection in the fourteenth century. I would argue, however, that the drawing represents a new phase in the history of anatomy.

The drawing (see Fig. 1.1) shows an anatomist - perhaps Vigevano himself who has just put his scalpel into a dead body that is standing next to him. While cutting, the anatomist carefully and closely holds his arm around the dead body to support it. Understandably, perhaps, the two do not seem to be in high spirits, and the anatomist's gaze can even be characterized as slightly apologetic. The scalpel's red incision in the dead body is mirrored in the anatomist's gown, as if to underline that cutting into a body also leaves a scar on the dissecting anatomist. Similarly, the facial expression of the dead man is reflected in the face of the anatomist, who looks attentively at the dead face, rather than at his own busy hands and the dead body. His posture suggests sympathy and empathy with the deceased. The reopening of the human body, which had been closed for many centuries, is represented here as a daring and frightening act that accordingly calls for a certain measure of restraint. Even to medical students today, making the first incision into a dead body still represents a threshold that most are unlikely to cross straight-faced. This particular image by Vigevano represents that special moment for a whole new generation of medical students. As we know, this renewed interest in the human body initiated in the fourteenthcentury had far-reaching consequences for the development of anatomical knowledge, as well as for our culture in general.

If we take a closer look at the drawing, it is striking that the dead body is depicted as nearly transparent. The bones of the chest, the muscles of the neck and the joints of arms, shoulders and legs are visible. We see in fact all the things 
we may identify once the body is cut open. Yet, we do not see the body's interior. In contrast to the anatomist, who is represented as moving around in the image's spatial realm, suggesting its three-dimensionality, the dead body seems more like a cardboard figure. This may stress that the living belong to our spatial realm, while the dead exist outside of it. The anatomist has not yet really discovered and explored the body's interior. The draughtsman, in other words, is not yet capable of representing the interior spaces of the anatomical body. In that sense, Vigevano's drawing suggests in particular the fragmentational and violent character of anatomy (Hodges 1985, 6). It reveals the uncontrollable urge of fourteenth-century anatomists to open up the human body again, regardless of all kinds of social, religious and cultural objections and despite their deep respect for the closed, intact body.

The drawing shows forth several issues. It is firstly meant to generate knowledge about the anatomy of the human body and about the technique of a dissection. This is also clear from the text accompanying the drawing: "This is the second plate of the dissection, which shows how the belly is cut open, so that all parts therein are visible; namely: the three layers of the abdominal wall: muscles, peritoneum and serous membrane, behind which there are the intestines, spleen, liver, kidneys and the urine and semen passage". Vigevano's drawing is secondly a cultural representation of what it means to open up the human body. The drawing's emotional appeal has a decidedly ethical dimension, which is expressed in the posture and face of the anatomist who is aware of the transgressive nature of his work. As the act of the dissection breaks open the integrity and the unity of the body, the drawing exposes the crossing of an ethical boundary. By depicting the emotion of this transgression, the drawing contributes to the cultural embedding of the new practice of anatomical dissection. The reader of Vigevano's Anathomia thus obtains major information about the technical ins and outs of opening bodies and about what is inside the body. Inextricably bound up with this factual, technical and anatomical knowledge, the reader also gains insight into the emotional and ethical dimension of dissection. The acquired knowledge, which is described in straightforward terms in the accompanying text, somehow justifies the ethical and emotional transgression that is part and parcel of any dissection. The draughtsman is in fact looking for a balance between knowledge and ethics. It is necessary to open up the body in order to obtain new anatomical knowledge, but it involves an activity that the beholder should not take too lightly.

1 "Hec est secunda figura anathomie, sicut scinditur venter causa vivendi omnia membra que sunt in ventre, ut sunt primo tres paniculi, scilicet mirac, sifac et zirbus et post hec sunt intestina, splen, epar et renes, et vie urinales et vie portantes sparma". 


\section{Leonardo and Human Interiority}

The long transition from the first to the second period of imaging the body's interior, involved a shift from hand-based imaging technologies to machinebased ones. Each phase had its own specific problems. Vigevano was faced with a quite practical pictorial problem: how to depict something for which there was no pictorial tradition yet, that is, the interior of the human body? In my view, a draughtsman can develop these technical skills only after he has comprehended the emotions that are associated with opening up the human body. He must have understood and processed the anatomist's subjective reaction to the body's interior. Vigevano's drawing shows that the draughtsman does not yet go beyond the emotions that precede the opening of the body. The draughtsman was unable to solve this pictorial problem in a convincing manner, as we can see from the still unopened body in this picture.

In contrast, over a century later Leonardo da Vinci (1452 - 1519) developed several new drawing techniques that enabled him to represent the human body's interior convincingly. Throughout his life Leonardo was actively engaged in anatomical research; he performed several dissections of both human and animal remains. Numerous anatomical drawings by Leonardo have survived, of which most are breathtakingly beautiful on account of his brilliant control of the art of drawing. Leonardo was the first anatomist who confronted the problems of depicting both the new anatomical knowledge and the emotions that resulted from the experience of dissections. The late medieval methods of anatomical representation by anatomists such as Vigevano, were still inadequate to depict the new anatomical knowledge of the interiority of the human body. Elsewhere, I have demonstrated in more detail how Leonardo represents the human body's interior, what new drawing techniques he developed to do so, and how he integrated emotions of the dissection and consideration for the body's interior into his anatomical drawings (Zwijnenberg 2009a). Here it suffices to draw attention to the pictorial problem that faced Leonardo (and Vigevano before him): the problem that the enclosed space of the human body becomes visible only when that space is opened. This implies that a closed anatomical space can only be represented through the surfaces concealing that space.

One of the best known drawings in which Leonardo realized a convincing depiction of human interiority is a drawing of a foetus in the womb from about 1511 (Fig. 1.3). He supposedly made this drawing after a real dissection of a pregnant woman. Based on our present knowledge, however, we know that the drawing is not entirely correct, because the cotyledons are those of a cow and not of a woman. The drawing's highly emotional impact is due to the way in which Leonardo pictured the full-grown foetus. It is in a stooped position, its hands before the eyes, in a tightly fitting cavity, which strengthens the impression of 


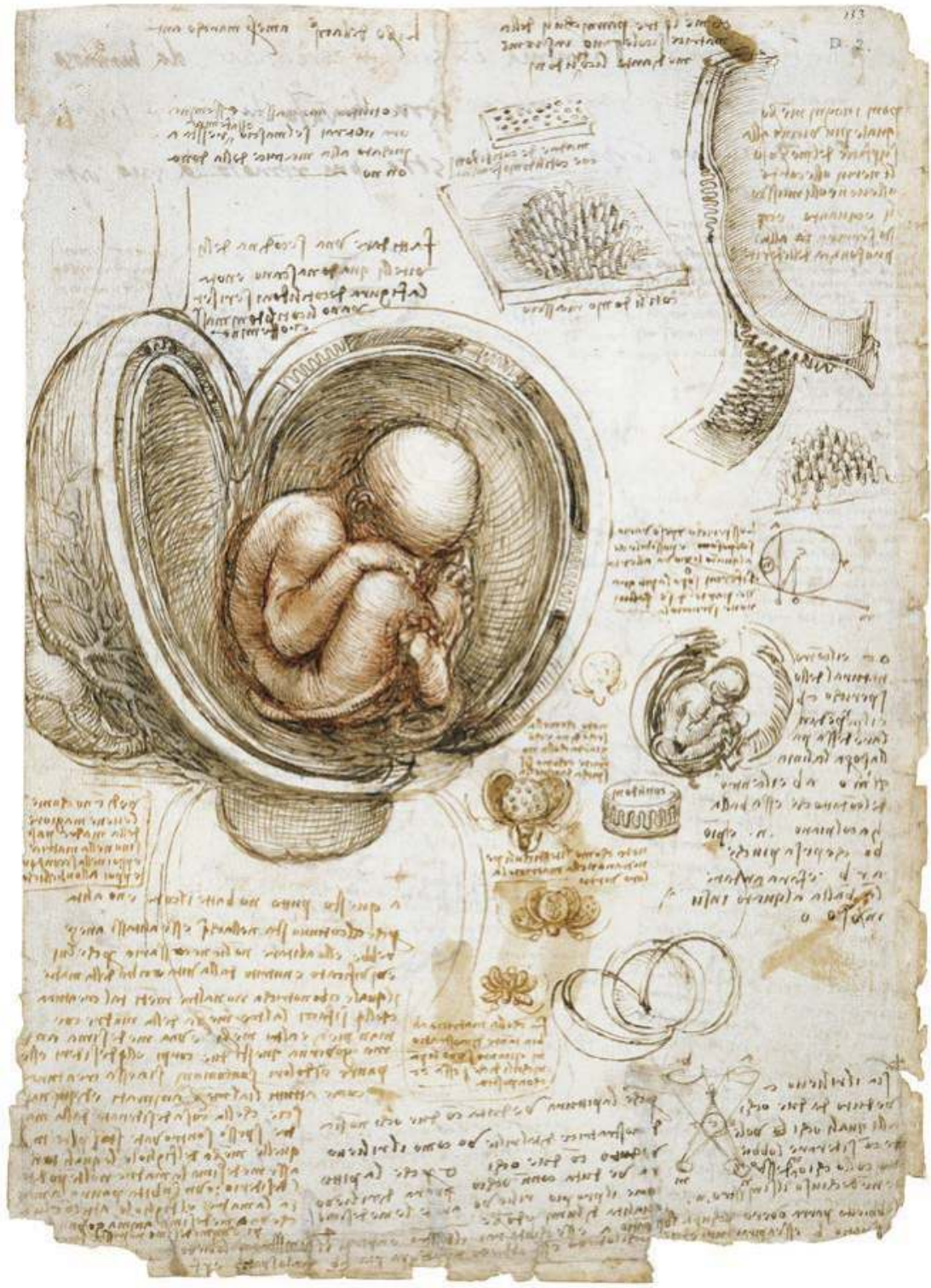

Figure 1.3: Leonardo da Vinci, The babe in the womb, c.1511, ink and chalk on paper, $305 \mathrm{x}$ 220 mm, RL 19102r. Courtesy The Royal Collection @ 2009, Her Majesty Queen Elizabeth II.

containment and seclusion. We could say that the foetus is depicted in such a way that the gestures and movements of its body seem to be an emotional response to its confinement in the enclosed space of the uterus. In this cut-away drawing 
Leonardo thus renders the inner space of the uterus visually accessible to the beholder. At the same time, the drawing presents us with the uterus as an enclosed anatomical space, because of our emphatic connection with the physical response of the foetus to its confinement.

In this particular drawing, Leonardo convincingly solved the pictorial problem of how to depict an anatomical interior, by suggesting the emotions of the foetus in its interior space. On the one hand, he demonstrates in both text and image his anatomical and physiological knowledge concerning the female body. On the other hand, his drawing contributes to cultural knowledge and understanding by offering a new perspective on the interior body. As such, the new anatomical knowledge about the foetus in the womb takes on an emotional and even ethical layer. The beholder is thus invited to integrate emotional and ethical aspects into more factual anatomical knowledge about pregnancy. Leonardo's drawing underlines my thesis that the integration of anatomical knowledge with its emotional and ethical dimensions in anatomical drawings, contributes to the cultural embedding of knowledge that is generated by the life sciences. Such images can thus help to induce and formulate a cultural response to the social and ethical consequences of scientific knowledge and its applications.

\section{Rembrandt and the Brain}

Leonardo's drawing is an anatomical drawing that he himself did not consider a work of art, unlike his Mona Lisa which he made as an artwork. Yet, there is earlymodern art that shows the cultural response to scientific knowledge of the human body. The case of the brain is quite interesting in this respect. Where in the early-modern period countless graphic representations of the brain can be found in anatomical handbooks or atlases, in artistic paintings from that same era this organ is virtually absent. Rembrandt's The Anatomy Lesson of Dr Deijman (1656) is one of the exceptions. It depicts a dissection of the brain and is quite a unique case, even when put in the tradition of anatomy pieces (Zwijnenberg forthcoming). ${ }^{2}$ To represent the brain, Rembrandt used an image from Vesalius's De humanis corporis fabrica (1543, book 8), which shows the various

2 Insofar as Esther van Gelder and I were able to determine - based on literature and collection study - there are only two other early-modern paintings depicting the brain. One of them is entitled Il Cervello (circa 1660), which is part of three 'educational' paintings for the anatomy museum of the Roman surgeon Guglielmo Riva (Museo Storico Nazionale dell' Arte Sanitaria, Rome). The other painting is an anatomy piece by the Delft painter Nicolaes Rijnenburg, entitled The Anatomy Lesson of Dr Theodorus Hoogeveen (1773), depicting a separate head with an opened-up brain (Museum Prinsenhof, Delft). I would like to thank Esther van Gelder for her help. 
steps of the brain's dissection in great detail in a number of woodcuts. Although Vesalius carefully depicted the brain's convolutions and also showed the ventricles, thus appearing to show the relationship between material structure and brain functions, the Fabrica text actually reveals that he did not understand the relationship between brain structure and function. Vesalius wanted to acquire insight into the higher mental functions of imagination, meditation, reflection and memory, in their relation to brain matter. But much to his dismay he ran up against the scientific limits of his era, such as a lack of research instruments. Rather than pursuing his efforts to investigate this relationship, Vesalius "simply lamented that anatomy has its limits and that he could not form an opinion about how the brain regulates imagination, reasoning, and memory" (Finger 1994, 23).

Put in this context, Rembrandt's use of a woodcut by Vesalius implied an attempt on his part, at an artistic and visual level, to get a grip on the still unknown anatomical of the functions of the brain and its cultural meaning. This is supported by the fact that in composing the image of the highly foreshortened body of the subject anatomicum, Rembrandt relied on a popular drawing of the dead Christ (1478 - 85) by Andrea Mantegna. The Dutch painter solidly situated the striking scene of a brain dissection, which had never been painted before, in a long artistic tradition of the representation of Christ. The contemporary beholder of Rembrandt's Dr Deijman viewed this painting as a group portrait of eminent Amsterdam scholars, while it also provided him or her access to earlymodern debates about the brain. Rembrandt achieved that by placing the disturbing images of a brain dissection within a more familiar frame of Christ representations. At the time there was an often fierce public theological debate in response to Cartesian philosophy in Rembrandt's Amsterdam about the mind's location: in the brain or in the heart (cf. Sawday 1995, 153-57). The beholder may therefore have interpreted the complex imagery with some knowledge of contemporary debates. Rembrandt's painting thus became an element in a wider cultural process, which helped to integrate anatomical knowledge of the brain and its implications into the public domain.

This cultural embedding of scientific knowledge was possible because in Rembrandt's era, unlike today, art and anatomy were interrelated practices rather than distinct ones. Early-modern art and anatomy shared similar 'ways of knowing' (Pickstone 2000). In the early-modern period, collaboration between anatomists and artists was necessary for developing and conveying anatomical knowledge. They worked within the same knowledge system and shared similar natural philosophical and theological assumptions. The transfer of anatomical prints to artistic paintings did not imply that these prints entered unknown or even hostile territory or that the original scientific meaning became unintelligible. Rather, it involved additional meanings from artistic perspectives 
which brought the anatomical drawings more firmly into a cultural and ethical context.

Rembrandt's use of a print by Vesalius within an iconography evoking dead Christ, granted his depiction of the brain dissection a more focused theological context. Rembrandt's artistic appropriation of Vesalius' original print thus opened up a religious dimension to a brain dissection that is not immediately visible in the woodcut. Through this shift in meaning vis-à-vis the original anatomical print, the painting could become a factor in the cultural embedding of natural philosophical knowledge about the brain, allowing the beholder to integrate anatomical knowledge in his or her available cultural and theological knowledge of man and nature. As such, Rembrandt's unique painting served as a contribution to a more pervasive cultural contextualisation of this specific knowledge from philosophy of nature.

\section{Brains and Art}

The close relationship and interaction between scientific insights and artistic imagination in the production of knowledge about the interiority of the human body drastically changed after the mid-nineteenth century. By the early twentieth century, the traditional close ties between anatomy and art in the production of anatomical knowledge were undermined by the invention of new medical imaging technologies. Essentially, the new imaging technologies rendered the visualizing role of artists in the production of anatomical knowledge superfluous. This had major effects on the relationship of artists to science and technology, while a hierarchical relationship between art and science unfortunately started to evolve. This development, in my view, has had dire repercussions for the cultural embedding of scientific knowledge and thus for the ethical and public debate on the implications of scientific knowledge.

Before 1895 it was impossible to have a visual experience of one's own inner body. In that year Wilhelm Röntgen developed a technique for rendering the inside of a living body visible without the need to cut it open. At that time, general knowledge about the inside of the human body had been available for centuries. By dissecting a dead body it became possible to see and gain knowledge of someone else's interior organs. Gaining direct knowledge or visual experience of the inside of one's own body, however, was usually - except under extreme conditions - beyond reach. A direct, visual confrontation with the inside of one's body involves one of the oldest taboos of human culture. Even modern surgeons are careful to shield off any possible sight of what is beneath the skin when performing an operation (cf. Sawday 1995, 6-15). As a result, the experience of our interior body still differs very much from the experience of the 
surface of our body. Paradoxically, we hardly have any direct knowledge of that what is most intimate; our own inner body. We feel our heart beating, we hear our blood singing, we experience fresh oxygen being sucked into our lungs, or we perceive the sounds produced by our digestive system, but we have no direct access to or exact knowledge of what is inside our body. This is why many of us consider this inside abject and uncanny (cf. Knoeff 2008 and for a contemporary view Nancy's $(1992 ;$ 2005) reflections on the interiority of the human body).

Through the development of modern medical imaging devices such as X-ray technology, endoscopy, ultrasound, CT-scan, MRI-scan, and PET, we now have ample visual access to the body's interior. This modern imaging equipment offers an experience that can be viewed as a new cultural phenomenon: a gaze into our own living body. The same is true of modern brain research that is conducted with the help of these new technologies and that make it possible to visualize brain activity as an active area in the brain, associated with, for instance, memorizing, seeing, and speaking. This 'gaze' into the living brain, too, is a new cultural phenomenon. More and more books and articles, notably from a sociological and anthropological perspective, have meanwhile described the effects of this look into the living brain on our views of who and what we are (see the bibliographies in Beaulieu 2000; Dumit 2004; also cf. Thomas Metzinger's 2003 concern for an 'ethics of consciousness'). The new (visual) dimension is bound to influence the experience of our body and physicality, as well as our notions of what or who we are as human beings. This inevitably raises new questions and problems with great cultural resonance: for example, where do we situate images of our body's interior in the overall image we have of our body? How do we integrate these images in our notion of self-identity?

It is therefore hardly surprising that in recent years many contemporary artists - including Zoe Leonards, Kiki Smith, Cindy Sherman, Mike Kelley, Mona Hatoum, Stansfield \& Hooykaas, and Richard Kriesche - have explored and interpreted this new visual experience in artistic ways. Using images that are generated by new medical imaging technologies, their artwork frequently centres on the experience of the body and of corporeality, of the body's interior, the boundaries between the body and the outside world, and the relationship between the body and technology. These artists thus try, among other things, to give meaning to a visual experience that has until now been devoid of meaning: the visual experience of our own inner body, including our brain.

However, the gradual separation between the traditions of artistic and scientific representation from the nineteenth century onwards, implies that contemporary artists relate differently to these images than early-modern artists related to anatomical drawings. As I argued above, early-modern artists and anatomists acted within the same system of knowledge production sharing the same philosophical and theological assumptions. If brain researchers and artists 
today start from quite different assumptions and use other methods of interpreting a brain scan, it does not necessarily mean that contemporary artists and scientists focus on completely different matters when looking at a brain scan. In fact, in modern brain research all sorts of problems - involving representation, the relation between structure and function, ethical issues concerning identity, and philosophical issues such as the Cartesian dualism of body and mind - play a role that are equally important to contemporary artists. But scientific treatises about the brain often betray an exclusively optimistic belief in progress regarding the uncovering of the secrets of the brain, while this confidence in the demystification of the secrets of brain and mind is interrogated in contemporary artistic practices. For instance, artworks by the British artist Susan Aldworth address the promise of transparency attached to brain images, the enigma of invisible thoughts arising from material structures, and issues involving identity and individuality (www.susanaldworth.com). By incorporating brain scans in her art, the work of Aldworth is pre-eminently suited for a study of the wider cultural ramifications of the insights generated in modern brain research about consciousness, the relation between brain and mind, and individual and identity. In this sense, she responds and provides answers to questions that are important to modern brain research as well. She thus provides brain scans with a cultural and ethical dimension, which is often glaringly missing from the medical domain.

\section{Art and Life Sciences}

Through her artworks, Susan Aldworth - just like Rembrandt before - contributes to a critical cultural embedding of scientific knowledge. However, because art and science have grown apart into two separate domains, this embedding no longer produces such cultural reverberation as in the days of Leonardo or Rembrandt. Art may still be considered an indispensable and necessary cultural activity, but effective answers to urgent social and political issues are mainly expected to come from science and technology. Although the cultural status and importance of the natural sciences are taken for granted, the cultural role or significance of the arts is much less apparent.

In this respect, the relationship of art with the life sciences is similar to that of the humanities. Scholars from the humanities seem increasingly less involved in the process of agenda-setting with regard to major issues and developments in science. This is even true of issues in society at large, where art and the humanities are equally absent in debates and areas where they traditionally played a large role, such as issues concerning our identity, the future, our goals and pursuits, and how to achieve them. Consider, for instance, the debates on genetic 
screening and predictive medicine, which both deeply affect our views on health and the relationship between present and past, as well as on death and human destiny, but which also have divergent economic and financial consequences (e.g. health insurance). These ethical issues and questions prompted by life sciences' research and products are more and more addressed or resolved within these sciences themselves. This happens, for example, in ethical commissions that rely on scientific expertise and standardized protocols. The life sciences have also assumed other relevant roles such as that of instigator and decisionmaker (cf. Zwijnenberg 2009b). The answers and solutions provided by such commissions, however, often seem to be strictly pragmatic and policy-oriented, while issues that require profound or fundamental ethical reflection are largely ignored.

Fortunately, a growing number of artists is sharply aware of the various implications of life sciences research. For example, the artist Eduardo Kac has written about the life sciences:

They affect the health of the individual but they also impact social relations. They dissolve species barriers and play a direct role in evolution. They create new life and unprecedented legal problems. They manufacture new products and redefine markets. Just as they influence notions of personal identity, they also change cultural patterns (Kac 2007, 3).

Artist Suzanne Anker speaks of the commodification of nature and the body: "Genetic engineering techniques transform living things - plants, animals, and human bodies - into marketable biomaterials. Animal bodies are engineered and cloned to serve as research tools. Human body tissue is turned into valuable raw material for pharmaceutical products" (Anker and Nelkin 2004, 153). These artists conclude that we hardly know as of yet where developments in the life sciences will lead. At least there is ample reason not to leave reflection on these developments up to life scientists alone, but to involve as many voices as possible - including those of artists - in public and academic debates. We need artistic imagination as much as life-scientific expertise to understand what life, in fact, amounts to and to find out which attitude our society ought to adopt in response to new life sciences knowledge.

In their artworks, many of these artists provide an artistic representation of the issues by infusing life sciences images with specific ethical and emotional dimensions. This applies in particular to a new form of art, called bioart, which is explored in the third part of this volume. Bio-artists are artists who actually participate in the practice of the life sciences; they literally create art in the laboratory. This means that they use living materials and the tools and technologies of the life sciences as artistic medium. Through this shift of materials 
from the life scientific domain to the artistic domain these artists are capable of evoking new meanings and ethical questions of the kind that emerge rarely within the life sciences themselves.

Of course, the early-modern practice in which the arts played a vital role in the cultural dissemination and embedding of anatomical and physiological knowledge will not return anymore. Yet bioartists, through their very participation in new scientific practices, are capable of bringing about a new relationship with the life sciences - one in which the increasing separation of art and science is not so much cancelled, but in which artistic reflection can become part of scientific practice. The work of bioartists, it seems, may serve as a counterbalance for the absence of ethical concerns or a wider cultural perception of life in views and representations put forward by the life sciences. Let me conclude this essay by turning to one such example of bioart.

\section{Tissue engineering and art}

A paradigmatic example of bioart is the Disembodied Cuisine project by the artists group Tissue Culture and Art Project (TC\&A). In Disembodied Cuisine, tissue engineering is deployed to grow a frog's muscle tissue on a biopolymer, eventually to serve as food for human consumption. During an international biological art exhibition, L'Art Biotech in Nantes in March 2003, the bits of meat grown in this way were marinated and roasted in calvados and eaten by a select gathering of artists during a theatrical banquet.

At universities worldwide, research is done on growing muscle tissue from stem cells of animals such as pigs to produce cultured meat. Unlike meat from the bioindustry, cultured meat (also called in vitro meat) is 'animal-friendly' and as a potential source of proteins it may be a solution for an increasing and hungry world population. The project's artists recognize the animal-friendly, ecological and economic advantages of cultured meat, but through Disembodied Cuisine they also seek to explore both the positive and negative implications of this technological development. In-vitro meat will change how we relate to living beings. In this respect, we should realize that by eating this meat we eat a new entity, also called Semi-Living. It is not life because its growth is fully controlled by people; but neither is it dead because it grows and is derived from animals. On their website the artists write rather dramatically: "However, by making our food a new class of object/being - a Semi-Living - we are risking of making the Semi-Living the new class for exploitation" (www.tca.uwa.edu.au/disembodied/ dis.html). By organizing a festive meal to eat laboratory-grown frog tissue in public, the project confronts the audience with the consequences of specific lifescientific technologies. In doing so, the artists raise ethical questions about 
tissue engineering that have so far been largely ignored within the scientific domain.

Another work by TC\&A is Victimless Leather, an installation in which a small leather jacket is grown in vitro, supported by a biodegradable polymer matrix shaped like a miniature coat. The work consists of laboratory glassware filled with nutrient media, tubes and a peristaltic pump. In this artwork, tissue engineering is used for an application that serves no scientific use or goal whatsoever, but is instead put in an ironic light, if not ridiculed. At the end of the exhibition of this work, the audience is invited to participate in the so-called killing ritual: to stop the growth of the leather jacket by touching the tissue by hand, which contaminates the tissue and stops its growth.

At first sight these projects hardly show more - also in terms of visual representation - than what we can see in a life sciences lab: the growing of tissue by means of tissue engineering. However, these artists have added a specific ethical dimension to tissue engineering and life-scientific imagery by framing their projects with artists' texts on websites and in catalogues, and by their performance in art galleries based on rituals such as the banquet and killing ceremony. In their artistic representation of tissue engineering, artists such as TC\&A have linked up a philosophic, ethical and cultural dimension with tissue engineering that the life sciences themselves have failed to generate so far. Bioart thus brings about a critical cultural embedding of this new technology, enabling art to again act as a participant in the public debate on the life sciences. Such participation by artists is crucial, if we value public discussions on these concerns that are not exclusively dominated or guided by life sciences experts. TC\&A is but one example of a growing number of artists who, by making art in laboratories, want to participate in the cultural reflection on the implications of research in the life sciences (Reichle 2009).

\section{Conclusion}

It is of course difficult to compare contemporary artists like Susan Aldworth and TC\&A with artists like Vigevano, Leonardo or Rembrandt, if only because today the gap between art and science has grown so large. But the work of these contemporary artists at least emphasizes that the arts can and must have a role in academic and public debates about the life sciences. As such, these artists offer a challenge to scholars in the humanities. The ways in which artists seek to incorporate artistic imagination into life-scientific reflection should encourage scholars in the humanities to add reflections from their specific angle to critical issues that are raised by developments in the life sciences.

When we now return to the micrograph of the stem cell introduced at the 
beginning of this essay, I hope to have elucidated that the philosophical, ethical and cultural implications of life-scientific reflection on life concealed in this image can be uncovered through artistic imagination. Art can do so in ways that differ fundamentally from how this is done in various standard forms of science dissemination, such as in an article in a newspaper's science section or in a life scientist's contribution to a public debate. Life sciences research has farreaching consequences for society and will be accompanied by shifting paradigms. Its various possible effects and repercussions are even hard to assess for the scientists who work on the development of new technologies in this field, and there is a risk of an even wider gap between science and society. By making the artistic imagination part of life-scientific reflection on life, this gap can perhaps be diminished again, if not closed. Art and science need each other when it comes to understanding, imagining and depicting life.

\section{Bibliography}

Anker, S., and D. Nelkin. 2004. The Molecular Gaze. Art in the Genetic Age. New York: Cold Spring Harbor Laboratory Press.

Beaulieu, A. 2000. The Space inside the Skull. Amsterdam: University of Amsterdam.

Dumit, J. 2004. Picturing Personhood. Brain Scans and Biomedical Identity. Princeton and Oxford: Princeton University Press.

Finger, S. 1994. Origins of Neuroscience. A History of Explorations into Brain Function. Oxford: Oxford University Press.

Hodges, D.L. 1985. Renaissance Fictions of Anatomy. Amherst: University of Massachusetts Press.

Kac, E., ed. 2007. Signs of Life-Bio Art and Beyond. Cambridge, MA: MIT Press.

Knoeff, R. 2008. Animals Inside. Anatomy, Interiority and Virtue in the Early Modern Dutch Republic. Medizinhistorisches Journal 43: 1-19.

Metzinger, T. 2003. Der Begriff einer Bewusstseinskultur. In Year Book 2002/2003 of the Wissenschaftszentrums Nordrhein-Westfalen, ed. G. Kaiser, 150-171. Düsseldorf: Wissenschaftszentrum Nordrhein-Westfalen.

Nancy, J.L. 1992. Corpus. Paris: Métailié.

Nancy, J.L. 2005. La Déclosion. Paris: Editions Galilée.

Pickstone, J. 2000. Ways of Knowing: A New History of Modern Science, Technology and Medicine. Manchester: Manchester University Press.

Reichle, I. 2009. Art in the Age of Technoscience: Genetic Engineering, Robotics, and Artificial Life in Contemporary Art. Wien/New York: Springer Verlag.

Sawday, J. 1995. The Body Emblazoned. Dissection and the Human Body in Renaissance Culture. London \& New York: Routledge.

Zwijnenberg, R. 2009a. Leonardo and Female Interiority. In The Body Within: Art, Medicine and Visualization, eds. R. van de Vall and R. Zwijnenberg, 15-30. Leiden: Brill Press. 
Zwijnenberg, R. 2009b. Art, the Life Sciences, and the Humanities: In Search of a Relationship. Preface to Art in the Age of Technoscience: Genetic Engineering, Robotics, and Artificial Life in Contemporary Art. I. Reichle, xv - xxxi. Wien/New York: Springer Verlag.

Zwijnenberg, R. Forthcoming. Brains in Art and the Humanities. In The Neurosciences in Contemporary Society: Glimpses into an Expanding Universe, ed. F. Ortega and F. Vidal. Cambridge/New York: Cambridge University Press. 
Open-Access-Publikation im Sinne der CC-Lizenz BY-NC-ND 4.0 (C) 2010, V\&R unipress GmbH, Göttingen 


\section{Chapter 2: Reflecting Imaginaries: Science and Society in the Movies}

\section{Introduction}

For the film industry, science and scientists are more than a topic and a character; they are the figures that have largely determined the technical and cultural origins of cinema itself. It is therefore no surprise that the 'seventh art' has featured rich portraits of science and scientists throughout its history. From the origins of cinema to the newest forms of distribution of moving images, scientists have populated the first (cinema), second (TV) and even the third (mobile \& web) technology of screens: dressed in their white coats, in a business suit or with the hat of the adventurer, scientists range from idealists full of hopes, to masters of evil powers threatening the safety of the world, to historical figures or science fiction characters. As science is part of popular culture (although not always in the forms that science itself would desire), movies cannot be neglected in investigating science and its relation to society. Movies are a wonderful tool to analyse how science permeates - and sometimes is permeated by - popular culture. Depending on what we define as a scientist or as a scientific topic (is any doctor in a movie a scientist?), and which corpus of data we consider (are all science fiction films about science?), it is possible to count between a few hundred (Merzagora 2006a) to several thousands of films (Martinet 1994).

In any case, these films certainly contributed to the shaping of the image of science and scientists among the general public. Indeed, popular films probably have a much larger impact on the public perception of science than attempts of science popularisation or dissemination of scientific culture:

Before reading a textbook or a popular science magazine, a citizen builds his own image of science and of scientists by smelling it out, more or less consciously, in soap operas, films, visual art, music. Studying scientific culture involves studying also these paths, and these contradictions, often embarrassing but terribly interesting (Castelfranchi 2003, 14, my translation). 
Following this indication, I will try in this article to sketch some of the pathways characterizing the representation of science and scientists on screen. ${ }^{1}$ I will do so by analysing how cinema reflected or influenced public perception of science and the interrelationships between science and society at large (Bucchi 2004). This analysis draws on a book that I published in Italian (Merzagora 2006a) where I analysed in detail some two hundred films, with science fiction films being just a minority restricted to science-based science fiction (see Lambourne et al. 1990). ${ }^{2}$

\section{Stereotypes of Science}

Like any form of narration, cinematographic tales select, retell and comment on themes of private and social lives. They are therefore part of those interpretative practices through which a society expresses its vision of the world (Buonanno 2002). Science is necessarily part of the story. Hollywood cinema, and to a lesser extent the European cinema, is probably the most important representative of what I define as 'implicit or unintentional science communication' (Merzagora et al. 2006). An example can help clarifying this aspect. In surveys analysing public attitudes toward science and technology (see Eurobarometer 55.2 and Special Eurobarometer 224 and 225), results consistently confirm that most Europeans perceive science as a positive, potentially beneficial activity, and scientists as trustworthy professionals, actually as the most trusted profession. However, when a more specific question is asked, a clear distinction emerges: scientists working for universities or publicly funded research centres are viewed much more positively than those working in a private company or for Ministries of Defence. A clear mistrust emerges when the idealistic objectives of science mingle with economic or military interests.

If we turn our eyes toward the screen, we see that this popular view is very much informed by the movies. Let us take as an example The Hulk. While some basic elements of the plot remain identical in the original comics and in all subsequent cinematographic versions, it is interesting to note how the scientific background is usually updated to follow current research as well as public

1 For reasons of space I limit myself to cinema, although there is obviously an increasing presence of scientific plots and characters in popular TV series such as CSI, ER, ReGenesis, Grey's Anatomy, House MD, Silent Witness, etc.

2 It can be useful to mention that since then two excellent books were published: in Mad, Bad and Dangerous? Christopher Frayling (2005) concentrates on archetypical representations of scientists, while in Hollywood Science Sydney Perkowitz (2007) focuses his analysis on Hollywood's science fiction productions. I also recommend Kirby, 2008 for an analysis of public communication of science and technology in popular films. 
anxieties. Thus, risks related to radiation in the remakes produced in the 1960s often turn into biotechnological risks in the 1990s. In Ang Lee's version of The Hulk (2003) all characters are scientists. The hero, Bruce Banner, is a biologist serving society: he works on a medical related project in a public laboratory. The origins of the genetic mutation combined with an overexposure to radiation that will eventually lead to his transformation into the green giant in shorts are to be traced back to his father. The father was both a biologist and a soldier who conducted research on tissue biology to create immortal soldiers. He was performing experiments on himself when he discovered that his wife was pregnant. Although he is responsible for the catastrophe of the son, he is not the bad guy of the plot, because his research was purely knowledge-driven. It only turned bad for an excess of ambition and for the external pressure of the military world. The bad guy is rather Bruce's ex-colleague and rival in love, who quitted the lab to work for a company where he is paid ten times more. This is indeed a familiar plot in movies about science: the scientist is a hero driven by humanitarian objectives whose good intentions are misdirected by a clumsy assistant, a greedy entrepreneur, the military, or the government.

The stereotypes depicted in the purely fictional film and in the objective enquiries of the surveys are strikingly similar. Did the screenwriters of The Hulk read the surveys on public perception of science before constructing the plot? I have no factual information on this, but I doubt it. ${ }^{3}$ Did The Hulk and other similar films influence public perception in constructing this specific image of science and scientists? Probably partly so, but it would mean attributing to popular cinema a greater power than I believe it actually has. Without constructing a one-to-one mirroring relation between cinema and the public image of science and scientists, I want to suggest that the cause for these converging representations is rather to be found in the fact that directors and scriptwriters of commercial cinema need to understand public feelings in order to move the audience. Similarly, Hollywood producers need to know and understand public desires, fears and expectations in order to sell their products. For filmmakers, then, understanding public perception of science is a matter of survival (Merzagora and Millington 2004; Merzagora et al. 2006). Popular films are thus a rich reservoir of the main fears and hopes that science has generated among the public throughout the years. Now that I have clarified the framework for my analysis of the representation of science and scientists on screen, it is useful to rewind and restart from the origins of cinema.

3 On the whole, however, scriptwriters tend to be well documented on the science involved in the plot, for example by taking advice from active science researchers (see for several, funny, exceptions Perkowitz, 2007; see Kirby, 2003 for an analysis of the role of science consultants on the set). 


\section{Scientific Origin of Cinema}

The history of the origin of cinema and its link with science has been well narrated by several authors (see Tosi 1984; Pesenti 2005). The three most important men who paved the way to the Lumière brothers' invention were an astronomer, a physiologist and a photographer serving scientific purposes. Pierre Jules-César Janssen was an astronomer famous for his discovery of the presence of helium in the solar spectrum, who set up a photographic revolver in order to record and study in detail the rare event of the passage of Venus in front of the Sun in 1883. Etienne Jules Maray was an eminent physiologist who devoted his research to the understanding of movement in birds and humans, for which he developed increasingly sophisticated systems of sequential imaging. Eadweard Muybridge was a photographer who was featured on the cover of the Scientific American in 1878 for his now world-famous sequence of photographs of a running horse. This series not only allowed to understand the horse's running technique, but also induced many to dream of moving images.

The birthday of cinema is now set at 28 December 1895. However, during the first years of its life, it was not clear whether it would become a scientific instrument for documenting and studying reality, or part of the entertainment industry as we know it today. Ironically enough, it was a fictional scientist that largely determined the fate of cinema as a storytelling device: professor Barbenfouillis, of the Academy of Improbable Science, project leader of the scientific expedition to the moon in Le voyage dans la Lune (Trip to the Moon) directed by Georges Méliès in 1902. The amazing success, both in Europe and America, of this astronomer's fourteen minutes dream, with its surprising special effects and visionary fantasy, influenced investors to finance the birth of the movie industry. In that sense, Méliès' scientific trip to the moon ended up posing the first stone of the Hollywood studios (Malthète-Méliès 1995).

\section{Scientists Populate Cinema}

One of the most interesting scientists in the history of silent movies is doctor Ics in René Clair's Paris qui dort (Paris that Sleeps 1923). Doctor Ics was responsible for the 'heavy ray' that set the entire world asleep, with the exception of groups of people who were high up on an airplane or on top of the Eiffel tower. Concentrated on his calculations, the scientist is oblivious to what he has caused: "I did not think about it!" Once he solves the problem by changing the equation, he asks to be left alone again and chases everyone from his laboratory.

Doctor Ics is a typical example of what can be referred to as the 'scientist in the ivory tower'. Pre-war cinema often features a clear separation between the sci- 
entist and the rest of society, which is signified by the isolated setting of the laboratory. The lab can be set in a castle, as in the film versions of Mary Shelley's Frankenstein, starting from the seminal 1931 Frankenstein with Boris Karloff in the role of the creature (Turner 1998); an island, as in the various versions of Herbert G. Wells' novel The Island of Doctor Moreau, starting from the 1932 version with Charles Laughton in The Island of Lost Souls (Joerg 2003); or even on a remote planet, as in Forbidden Planet (1956) where the scientist isolates himself on Altair- 4 to study the secrets of superior intelligence. All these physical places are set apart from society and the scientists are thus characterized by their distance and detachment from the world.

The representation of scientists in the movies gradually becomes more complex. The classic example of the interaction between science and social awareness is Fritz Lang's visionary film Metropolis (1927). As noted by Perkowitz: "Metropolis also portrays interactions among technology, society, and government: again, a theme in today's films that is important in the real world as well" (Perkowitz 2007, 6). Rotwang is one of the most influential cinematic representations of the mad scientist, who has inspired many screen scientists, even in details such as the black-gloved hand in Stanley Kubrick's Dr. Strangelove, (1964).

Yet, not all scientists are mad. Take for example the character of Sidney Stratton (Alec Guinness) in The Man in the White Suit (1951). He is an outsider genius squatting laboratory equipment in the chemical industries where he works as a cleaning man, who will eventually succeed in developing an indestructible and self-cleaning fibre. His invention does not provoke enthusiasm, as he imagined, but rather a sense of fear and anger. An unexpected alliance between the workers and the owners of the textile industry try to stop him from developing a product that would obviously transform the market and probably cause many of them to lose their job or their money. In a wonderful climax, the only person capable of stopping him is an old cleaning woman: "Why don't you scientists leave things alone? What about my little bit of washing, when there is no more washing to do". Without analysing the film in detail, it is sufficient here to note a more complex interaction between scientific discoveries and other social actors (Jones 1997; 2001).

We can carry on this thread by looking at David Cronenberg's The Fly (1986), a remake of the 1958 cult movie directed by Kurt Neumann (De Ceglia 2008). The physicist Seth Brundle (Jeff Goldblum) is depicted as an outsider, living in a separate world that only consists of physics. The development of the story is based on his professional and sentimental relationship with a journalist. $\mathrm{He}$ looks for her at the beginning of the film, and then tries to hide himself when he understands that she may write a story on him for a greedy editor. Here, we see 
the struggle of a scientist who wants to progress undisturbed, but realises at the same time the need to relate to society at large.

In the 1990s the separate boundaries between science and society are starting to disappear. In Gattaca (1997), for example, science is no longer isolated in an ivory tower, but has permeated the world to the extent that science is society. In the recent catastrophe film The Day After Tomorrow (2004), dealing with society has become an intrinsic component of the scientific work. At an international conference of climate change, professor Jack Hall (Dennis Quaid) explains the potential risks associated to a blockage of the Gulf current due to the melting of ice caps, to an audience of politicians, oil producers, representatives of third world countries, and scientists (Allen 2005). The 'economy versus environment' dichotomy, one of the themes that characterize the public debates on the Kyoto protocol, is explicitly introduced through a debate between the vice-president of the USA and professor Hall. Moreover, the film does not neglect the role of civil society because environmentalist protesters are portrayed outside the conference venue. Last but not least, the media participate in the game by covering the conference through a live TV event clearly portrayed at the end of the scene.

By embedding science so fundamentally in society, cinema seems to have perfectly integrated the notion of 'post-academic science' as developed in the field of science and technology studies - that is, a mode of production of scientific knowledge where key decisions are taken by a plurality of actors, also beyond those explicitly in charge of this role (Ziman 2000; Novotny 2001; Greco 2001). It is interesting to note that, thanks to the way in which the leisure industry functions, this integration is the result of a purely bottom-up approach.

\section{Mad, Bad and Dangerous?}

Several authors have studied the representation of the scientist in cinema and tried to draw a classification (Weingart 2003; Frayling 2005; Rutherford 2005; Pansegrau 2007). Despite the common stereotype of the 'mad scientist', most recent studies actually show that this is by no means the most common representation of scientists on screen: "in addition to the nerd and the villain, there's a third important category with lots of occupants: the hero" (Perkowitz 2007). Haynes $(1994 ; 2003)$ even proposes seven categories: the evil alchemist, the noble scientist, the foolish scientist, the inhuman researcher, the scientist as adventurer, the mad, bad, dangerous scientist, and the helpless scientist. Jouhaneau (1997) and Martinet (1994) prefer to classify them as scientists, heroes, humans, the ambivalent, the weak, the dangerous, and assassins. Their analysis of over three thousand films yielded interesting results: first, the more positive image of the scientist is by far the most frequent type (a finding confirmed in 
Merzagora 2006a); and second, the type of scientist that is represented is related to the level of realism with which he is depicted. If the movie is more realistic in its story and the representation of science, the scientist is more likely to be presented as a positive hero.

The interest of cinema for scientists is not surprising, as they embody many features which can only please screenwriters: they have access to information or insights that other people do not have; master a largely obscure power; are often able to foresee or even predict the events; experience moments of great excitement and discovery; are often ahead of their time and thus misunderstood by the establishment; have to fight hard to be listened and let the truth triumph; etcetera. They are thus very complex characters that carry the possibility for dramatic narratives.

The main characteristic of scientists on screen is, however, their ambivalence (Merzagora 2006a; Weingart 2007). They are 'good' in their desire to understand and improve the world, but they become 'bad' when they try to master and control the world. The most common plot involving scientists, therefore, concerns an unstable equilibrium between knowledge and power. The transformation of knowledge into power can lead to a positive outcome, as is the case of the 'scientist-Cassandra' anticipating and eventually facing a catastrophe (Volcano 1997; Deep Impact 1998; Twister 1996) or the 'stubborn' scientist who manages to establish contact with extra-terrestrials (Contact 1997; Close Encounters of the Third Kind 1977), or to the affirmation of a scientific truth (The Story of Louis Pasteur 1936). A specific subgenre is the biopic of great scientists of the past, where the narrative is usually based on the struggle of the scientist against an establishment that is incapable of accepting novelty; notable examples are the many films devoted to the lives of Louis Pasteur or Marie Curie (Elena 1993; Testa 2006). Obviously, the transformation of knowledge into power can also lead to catastrophe or tragedy, as in the case of the mad scientist (the many versions of Dr. Mabuse or Dr. Moreau), or in the various examples of stories in which scientific knowledge is not mastered and the scientist loses control (from the monster of Frankenstein to Outbreak 1995).

It is important to recall that while popular films can be an excellent tool to interpret public perception of science, filmmakers evidently stress those character traits of the scientists that better serve the cinematic narrative. In doing so, they tend to mix heavily stereotyped images with more realistic representations, in ways that the audience may not always recognize. For example, the scientist who wants to rule the world is easily identifiable by the spectator as a fictional character serving the plot. But the frequent representation of the moment of discovery as a sudden enlightenment giving rise to an Eureka! moment, tends to be seen by the audience as a more realistic representation of the work of a scientist. Yet, it is mainly a technique for the scriptwriter to achieve a narrative 
climax. In other words, the image of the scientist is a representation that does not merely reflect reality. Cinema also actively contributes to shaping public perception of science (Merzagora and Montfeuillard 2009). At the same time, I am convinced that the more the plot includes science-based, socially relevant issues, and the more serious these issues are, the more science in cinema has to be regarded as a tool for investigating public perception of science rather than as a driving force shaping this perception. This implies the recognition of a certain maturity of the public regarding the role of science in society, which is confirmed in studies on risk perception and communication (see Sturloni 2006).

\section{Which Science on the Screen?}

From the discussion above, it follows that the best definition of science as it is portrayed in fiction films is the one given by Collins and Pinch: "Science is a Golem. [...] Science is presented as a creature of mankind that can be useful and benign if kept under control, evil and disruptive if misguided, messy and sometimes irresponsible, never really responsible for its own mistakes" (Collins and Pinch 1993, 1). Indeed, as stated earlier, the most distinctive feature of science on the screen is its ambivalence. Cinema recognizes that science has the power to both understand and to change the world, and it exploits this double edged power to satisfy its narrative goals. This is why Dr Jekyll and Mr Hyde are present in so many films, either together in the same story, or wearing only one of the two hats. ${ }^{4}$ Collins and Pinch go on to explain that "for citizens who want to take part in the democratic process of technological society, all science they need to know about is controversial" (Collins and Pinch 1993, 4). It is indeed easy to observe that a second important feature of the representation of science on screen is its controversiality.

We need to combine the two main features of representations of science in cinema, ambivalence and controversy, with the need to take knowledge society seriously, as the European Union intends to (Felt et al. 2007). The main goal of explicit science communication should be a qualitatively higher participation of citizens in debates on science (Bucchi 2006). For science topics to become part of the cultural arena in media society, I then want to advance the argument that they need to be both ambivalent and controversial. This certainly does not imply a distorted representation of science. On the contrary, in a post-academic perspective, ambivalence and controversy are the most accurate representations of

4 This presence is not only metaphorical: there exist at least eight cinematographic versions of Stevenson's novel, the first dating 1908 and the last produced in 2004 (Merzagora, 2006a). 
the complexity of science in public eyes. In my view, these are also the noblest representations of science one can think of.

If we return to the actual practice of popular cinema, we can see that virtually every aspect of science has been dealt with in films (Merzagora 2006a). However, the feature of ambivalence outlined above leads to a recurrence of certain topics. This is particularly true of Hollywood mainstream cinema, which is often anchored in strictly defined genres. In addition to the classical science fiction topics such as encounters with alien worlds, Hollywood's scientific explorations tend to concentrate on natural catastrophes, man made disasters, manipulation of the living world, creation of artificial beings or intelligence, the relation between science and war (in particular the atomic bomb), and links between genius and madness (Perkowitz 2007). These are by far the most frequently discussed topics. And they are the kind of topics where science can feature in both its Jekyll and Hyde's suit: ambivalent and controversial.

Before concluding this article, I want to briefly refer to representations of science in European cinema. Contrary to Hollywood, European cinema tends to keep a distance from science, and scientists and scientific plots are much more difficult to find. The reasons for this remain to be elucidated. A simple answer would associate science in the movies with science fiction movies, a genre that for economic and cultural reasons is mainly US-centred. But as I pointed out earlier, science fiction is only part of the story, and not necessarily the most relevant. I suspect there are deeper cultural grounds behind this uneven geographical distribution, which also includes Asian, African, and Latino-American productions.

More surprisingly, science topics are also rare in European cinema. At the risk of being simplistic, I believe this mainly relates to the fact that European directors tend to focus their stories rather to their own sensibility than to public demand. Also, their educational background is rarely scientific. A least, such a conclusion was reached in a series of studies on the presence of science in TVdrama, based on interviews with directors and writers of fictional TV productions featuring science and technology. ${ }^{5}$ Although no specific research was carried out on cinema, it probably also applies to the large screen.

In the admittedly rare cases of European films that deal with science, in my view the story is usually told in a less stereotypical and more original way than in American movies. Of course, the comparison is not altogether fair, because of the distinct differences between popular Hollywood cinema and European au-

5 The topic of TV drama featuring science and technology was at the core of three projects funded by the DG Research of the European commission and carried out by the EuroPAWS initiatives in collaboration with other partners: Assend (2003), Eurowistdom (www.eurowistdom.eu), and Earthwake (www.earthwake.eu); see Merzagora and Millington, 2004. 
thor or art cinema. Most studies that draw large scale comparisons and classifications take into consideration a large number of American films, while analysis of European films mainly concentrate on a single production or on the works of one particular director. Yet, I want to briefly draw attention to the diversity and complexity with which European cinema has represented science, or a scientific topic or character (see Merzagora 2006a for a more extensive review). In the French film Le déjeuner sur l'herbe (Lunch on the Grass 1959), Jean Renoir portrays a caricature of a biologist so as to treat in a mildly surrealist way the ethical question of science controlling life, and more specifically birth. In Mon oncle d'Amérique (My American Uncle 1980), Alain Resnais conceives the story as an experiment on an experiment: how could Laborit's theories on behaviour be applied to the characters of a film (Serceu 1994)? More recently, Arnaud Desplechin discusses in Un conte de Noël (A Christmas Tale 2008) how statistics nowadays enters any discussion on life and death, by introducing the character of a Field Medallist (the equivalent of the Nobel prize for mathematics). In Germany, Werner Herzog strongly denounces the risk of obscuring the understanding of human nature by an overtly scientific approach in Jeder für sich und Gott gegen alle (Every Man for Himself and God Against All 1974). In Italy I ragazzi di via Panisperna (Via Panisperna Boys 1989) by Gianni Amelio and Morte di un matematico napoletano (Death of a Neapolitan Mathematician 1992) by Saverio Martone start from historical scientific events to construct very intimate stories. Other examples of European films on science include the cinema of Andrei Tarkovsky in Russia and of Krzysztof Zanussi (a director with a past in physics) in Poland.

\section{Conclusion}

In an interesting talk delivered at the 1999 meeting of the American Association for the Advancement of Science, novelist and scriptwriter Michael Crichton discussed criticisms of the common portrayal of scientists in feature films, including his own. He addressed the scientific community bluntly: "Scientists often complain to me that the media misunderstand their work. But, in fact, the reality is just the opposite: it is science that misunderstands media" (Crichton 1999, 1461). After reviewing some famous cinematic portrayals of scientists, he continued: "Don't these movie images provide some insight into the attitudes of the wider society? Don't they reflect society in some way?" His conclusion was clear: "No, they do not".

I entirely agree with Crichton. Science as portrayed in popular films is not and should not asked to be - a representation of real science. Neither are popular films - nor should they be - a faithful mirror of science in society. Cinema does 
not merely reflect society, but also helps to construct its views. The choices behind a box-office success, even if they may not follow specific strategies, are always intelligent choices, capable of grasping an element of public interest. For example, if it is true that Alan Grant in the film Jurassic Park (1993) is not necessarily a correct image of a scientist, Crichton's choice of having the plot sparking from a genetic-engineering laboratory (and a nanotechnology lab in the case of his novel Prey (2002), or a neuroscience and biotechnology lab in his 2006 novel Next) was based on his apt skills as a story-seller. That is, on Crichton's always bright intuitions about what raises interest and concerns in the public. Popular cinema can thus be a valuable tool to investigate the constantly changing public perception of science in the same way as cinema itself was born as a scientific instrument to capture a moving reality.

Crichton concluded his speech by pointing out to his audience of scientists that "our society is now dependent on technology, and dependent on science. With so much power, science will inevitably receive strong criticism. It comes with success. It's entirely appropriate. Take it as a compliment" $(1999,1462)$. I want to conclude my essay with a quotation from a TV-series that has analysed in depth and with intelligence the relationship between science and society: The Simpsons (Malaspina 2008). As is often the case, the 'family on the couch' has the capacity of turning upside down any common sense:

Lisa: "Isn't there any way I can change my DNA, like sitting on the microwave?" Dr. Hibbert: "Mmm, not according to any movie I've ever seen."

\section{Bibliography}

Allen, M. 2005. A novel view of global warming. Nature 433: 198.

ASSEND. 2003. Associating Science and Society in European New Drama (ASSEND): Research Report (www.europaws.org).

Bucchi, M. 2004. Science in society. London and New York: Routledge.

Bucchi, M. 2006. Scegliere il mondo che vogliamo. Cittadini, politica e tecnoscienza. Bologna: Il Mulino.

Buonanno, M. 2002. Le formule del racconto televisivo. Milano: Sansoni.

Campagnoni, D. P. 1995. Verso il cinema. Macchine spettacoli e mirabili visioni. Turin: Utet.

Castelfranchi, Y. 2003. Per una paleontologia dell'immaginario scientifico. Jcom 2 (3) http://jcom.sissa.it/archive/02/03/C020301/C020302 (accessed 08-07-2009).

Ceglia, F. P. de. 2008. Tutta la scienza di Cronenberg. Scienza e società 3(4): 125 - 30.

Clarke, B. 2007. The Self-Referential Scientists. In Science Images and Popular Images of the Sciences, eds. B. Huppauf and P. Weingart. New York: Routledge. 
Collins, H. and T. Pinch. 1993. The Golem. What everyone should know about science. Cambridge: Cambridge University Press.

Crichton, M. 1999. Ritual Abuse, Hot Air, and Missed Opportunities. Science 283(5): 1461 63.

Elena, A. 1993. Exemplary lives: biographies of scientists on the screen. Public Understanding of Science 2: 205-23.

Felt, U. et al. 2007. Science \& Governance - Taking European knowledge society seriously. EUR 22700. Luxembourg: Office for Official Publications of the European Communities.

Frayling, C. 2005. Mad, bad and dangerous? The scientist and the cinema. London: Reaktion Books.

Greco, P. 2001. Communicating in the post-academic era of science. Jcom 1. http:// jcom.sissa.it/editorial/edit0101.pdf.

Haynes, R. 1994. From Faust to Strangelove: Representation of the scientist in Western literature. Baltimore: The Johns Hopkins University Press.

Haynes, R. 2003. From alchemy to artificial intelligence: stereotypes of the scientist in Western literature. Public Understanding of Science 12: 243-53.

Kirby, D. A. 2003. Science consultants, fictional films, and scientific practice. Social Studies of Science 33: $231-68$.

Kirby, D. A. 2007. The Devil in Our DNA: A Brief History of Eugenics in Science Fiction Films. Literature and Medicine 26(1): 83-108.

Kirby, D. A. 2008a. Hollywood Knowledge: Communication Between Scientific and Entertainment Cultures. In Communicating Science in Social Contexts, New models, new practices, eds. D. Cheng, M. Claessens, T. Gascoigne, J. Metcalfe, B. Schiele, S. Shi. New York: Springer.

Kirby, D. A. 2008b. Cinematic Science: The Public Communication of Science and Technology in Popular Film. In Handbook of Public Communication of Science and Technology, eds. M. Bucchi and B. Trench. London: Routledge.

Jones, R. 1997. The Boffin: a stereotype of scientists in post-war British films (1945-1970). Public Understanding of Science 6: $31-48$.

Jones, R. 2001. 'Why can't you scientists leave things alone?' Science questioned in British films of the post war period (1945 - 1970). Public Understanding of Science 10: 365-82.

Jouhaneau, J. 1997. Un savant à Hollywood. Science et avenir special issue: 50 - 57.

Jörg, D. 2003. The good, the bad and the ugly: doctor Moreau goes to Hollywood. Public Understanding of Science 12: 297-305.

Lambourne, R., M. Shallis, and M. Shortland. 1990. Close encounters? Science and science fiction. Bristol and New York: Adam Higler.

Malaspina, M. 2008. La scienza dei Simpson. Guida non autorizzata all'universo in una ciambella. Milan: Sironi.

Malthète-Méliès, M. 1995. Méliès l'enchanteur. Paris: Ramsay.

Martinet, A., ed. 1994. Le cinéma et la science. Paris: CNRS Edition.

Merzagora, M. and A. Millington. 2004. Science and society in European TV drama, Proceedings of PCST 2004. www.pcst2004.org/ing/pdf/Parallel_Session_15.pdf.

Merzagora, M. 2006a. Scienza da vedere. L'immaginario scientifico sul grande e sul piccolo schermo. Milan: Sironi editore.

Merzagora, M. 2006b. Scienziati di celluloide. Quark 62: 60 -6. 
Merzagora, M. , A. Millington, and M. Scandola. 2006. Science in TV drama. Science as part of the story. In Science and the power of TV, eds. J. Willems and W. Goepfert. Amsterdam: VU University Press.

Merzagora, M. and H. Monfeuillard. 2009. La communication scientifique implicite: quelle image de la science au cinéma? In Actes JIES XXX - Journées Internationales de l'Education Scientifique, Chammonix, May 2009 (In press).

Novotny, H., P. Scott, and M. Gibbons. 2001. Re-thinking science: knowledge and the public in an age of uncertainty. Cambridge: Polity Press.

Pansegrau, P. 2007. Stereotypes and Images of Scientists in Fiction Films. In Science Images and Popular Images of the Sciences, eds. B. Huppauf and P, Weingart. New York: Routledge.

Perkowitz, S. 2007. Hollywood science. New York: Columbia University Press.

Rutherford, A. 2005. Scientists on screen. Nature 438: 25-26.

Serceu, D. 1994. Cinéma scientifique et fiction: Mon Oncle d'Amérique, Cinémaction 38: $102-07$.

Sturloni, G. 2006. Le mele di Chernobyl sono buone. Milano: Sironi.

Testa, A. 2006. Scienziati al cinema: le biografie scientifiche. In Governare la scienza nella società del rischio, Proceeding of the IV National Congress of Science Communication, ed. N. Pitrelli and G. Sturloni. Monza: Polimetrica.

Tosi, V. 1984. Le origini del cinema scientifico. IWF. Luce. CNRS.

Turney, J. 1998. Frankenstein's Footsteps. New Haven \& London: Yale University Press.

Weingart, P. and P. Pansegrau. 2003. Perception and representation of science in literature and fiction film. Public Understanding of Science 12: 227-28.

Weingart, P. 2007. The ambivalence Towards New Knowledge. In Science Images and Popular Images of the Sciences, eds. B. Huppauf and P. Weingart. New York: Routledge.

Weingart, P., C. Muhl and P. Pansegrau. 2003. Of power maniacs and unethical geniuses: science and scientists in fiction film. Public Understanding of Science 12:279-87.

Ziman, J. 2000. Real science. What it is and what it means. Cambridge: Cambridge University Press. 
Open-Access-Publikation im Sinne der CC-Lizenz BY-NC-ND 4.0 (C) 2010, V\&R unipress GmbH, Göttingen 


\section{Chapter 3: Reappraising Futurist Mechanical Art ${ }^{1}$}

\section{Introduction}

In E. M. Forster's story 'The Machine Stops' (1909) Kuno pleads emphatically with his mother Vashti:

"I want to see you not through the Machine," [...]. "I want to speak to you not through the wearisome Machine." "Oh, hush!" said his mother, vaguely shocked. "You mustn't say anything against the Machine." "Why not?" "One mustn't." "You talk as if a god had made the Machine," cried the other. "I believe that you pray to it when you are unhappy. Men made it, do not forget that. Great men, but men. The Machine is much, but it is not everything [...] (Forster 1984, 110).

The story is written, by its author's admission, in "reaction to one of the earlier heavens of H. G. Wells" (Forster 1984, 6). Forster's approach to technology centres on a mechanical entity first created and subsequently fetishised by human beings. He cautions readers against the temptation to worship technology as a deity in its own right, an all-controlling Machine holding 'unmechanical' humans under the threat of 'homelessness'.

Forster's apocalyptic stance could not be further removed from the indiscriminate endorsement of the machine, understood here as a motorized machine, informing the 'Foundation and Manifesto of Futurism', published by Filippo Tommaso Marinetti on the pages of the Parisian daily Le Figaro in the same year as Forster's story came out in print. Officially inaugurated by Marinetti on 20 February 1909, and existing, albeit in revised form, until Marinetti's death in 1944, the movement of Futurism proposed, promoted, and actively pursued a radically modern artistic theory and practice within the social sphere.

Indeed, Futurism both proposed and pursued vigorously an original aesthetic re-thinking of artistic practice, hinging on contamination and hybridisation

1 Acknowledgments are due to the British Academy who generously awarded me a Small Research Grant enabling me to carry out research for this chapter. 
between visual, textual and scientific discourses. This essay aims to illustrate the manners in which the Futurist movement imagined and carried out this convergence by focussing on some of its most prominent figures, such as Marinetti, Paladini and Pannaggi. It further aims to consider both its least persuasive (Marinetti) and its most convincing (Pannaggi, Paladini) intellectual and artistic articulations and outcomes.

In particular, Futurism's engagement with machine art and mechanical aesthetics was sustained from the very inception of the movement, as testified by the prominence given in the founding manifesto, to the motor-car crashed by Marinetti a year earlier, in 1908, an accident related in both graphic detail and bombastic tones. On a leisure outing in the countryside, young and daring, though under-experienced, Marinetti had swerved suddenly his shiny new racing car, in the vain attempt to avoid running over two cyclists who were blocking his way. The car crashed spectacularly when its inept driver was forced to steer it into a moat at the roadside. Unfazed, Marinetti emerged phoenix-like from the putrid industrial sludge, burning ever more fiercely with machinist intent and passion (Marinetti 1973, 19-24).

\section{A Serious Engagement with Machines}

The premises of a serious engagement with machines, together with the structures, processes and products of societies in rapid course to becoming industrialized, were laid out in the first Futurist phase, before the First World War. Its main agents were Umberto Boccioni, whose paintings and sculptures were forcefully informed with dynamism and 'force lines', as well as Giacomo Balla (1871 - 1958) and Gino Severini (1883-1966), whose machine-informed work was seminal, if not always sustained. In particular, Severini's early Futurist affiliations notably resulted in his essay 'Macchinismo nell'arte' ('machinism in the arts'), an early conceptualization centred on the role played by machines in the artistic practice, originally published in the journal Mercure de France in 1916.

In the prewar period, as well as immediately after the war, however, Futurist machines emerge most visibly and forcefully in the domain of theatre, as testified, in particular, by the stage designs of Giacomo Balla, the Plastic Ballets of Fortunato Depero, and the 1920s Pantomimes and Magnetic Theatre of Enrico Prampolini. Consisting of mechanically operated and colourful puppets, Depero's and Gilbert Clavel's Plastic Ballets were staged in 1918 and performed by wooden marionettes moving robotically (Berghaus 1998). Other prevalently visual artists joined the Futurist cohort at this time, including Ivo Pannaggi and Vinicio Paladini, who, in 1922, published an influential 'Manifesto of Mechanical 
Art'. The sustained, widespread, and ominous employment of technology in the First World War, together with the consolidation of industrial societies in the postwar, encouraged both artistic and intellectual reflections on machines. These reflections stimulated, in turn, serious individual conceptualisations and, occasionally, articulated formulations of machine aesthetics. The spectrum of positions ranged from a widespread macchinolatria (technophilia; an idiom whose paternity is generally attributed to Boccioni), to a frequently less explicit but nonetheless distinctive undercurrent of macchinofobia (technophobia).

As testified by his first, as well as various subsequent manifestos, Marinetti's position $v i s-\grave{a}$ - $v$ is technology consisted in an unapologetic endorsement spanning across his lengthy, unorthodox career. Since early on, Marinetti's endorsement had centred on the theme of 'electric power'. His thought echoed a smattering of disparate ideas, including Boccioni's dynamism, Rudolf Steiner's theosophy, spiritualism and the paranormal, William James' and Henri Bergson's theories, somewhat indiscriminately clustered together. The city of Milan, Marinetti's Futurist metropolis par excellence, had been endowed with 9,550KW's worth of electricity by the newly built power station at Paderno, near Varese, which became operative in 1898 and was the largest in Europe at the time. Powering public lighting, transports and local industry, the power station was pivotal in stimulating an Industrial Revolution in Italy, a belated development when compared with other western European countries, largely dating back to the years 1898-1913. The power station is one of the most visited themes in Marinetti's early work, beginning with his essay 'Futurism' of 1912. Marinetti views the power station as a rigorous, aseptic space, controlled by an elite of busy and efficient technocrats, wearing spotless white overalls. As such, Marinetti's brilliant, glamorous, and clean image of technology will seep into the collective imagination, resurfacing later on, in the 1930s and 1940s, under the guise of Aero-futurism. Most importantly, Marinetti appears to equate indiscriminately electricity with mechanics, employing the terms 'machine' and 'electricity' interchangeably, at least since his play Sexual Electricity.

Following Marinetti's early and indiscriminate enthusiasm for machines and electricity alike, considered as interchangeable markers of a generic modernity, the whole Italian Futurist group appears to have embraced technology unconditionally and even uncritically. This infatuation was not, however, without its problems, ambiguities and contradictions. Frequently a veneer of vociferous praise was painted over, disguising latent doubts, anxieties, and fears, as encapsulated, for instance, in Anguish of Machines, a 1925 play by Ruggero Vasari, first staged in 1927. 


\section{Pessimism versus utopianism}

In the wake of E. M. Forster's chilling technological prophecy, the whole modernist age seems to be riddled with pessimistic caveats. These include, most prominently, the crisis of positive values leading to the demise, the 'sunset', of Western civilisation foretold by Oswald Spengler in his Decline of the West (1918-22). In Man and Technics (1931), Spengler further proposed a re-elaboration of the Faustian pact: humankind may well have conquered technology, but at the cost of foregoing Beauty in the process. Another example are the nihilist, aggressive labourers in The Worker: Dominion and Gestalt (1932) of the conservative author Ernst Jünger. They are technological soldiers and mechanic workers at the same time; hybrid techno-beings bending machines to their superior will. Jünger's prospected onset of a technological age was widely influential. Amongst others, it is likely to have prompted his friend Martin Heidegger (1954) to reflect on technology's unique ability to remould our modes of engagement with the world, a world where humans have become part of a wider technological machine, along the lines of E. M. Forster's dystopian predictions. Walter Benjamin's fragmentary and ambivalent consideration of technology, particularly as it emerges in his renowned essay 'The Work of Art in the Age of Mechanical Reproduction' (1936), applauds the liquidation of aura and tradition brought about by the modern technologies of artistic reproduction. At the same time, however, Benjamin cautions his reader against the risk of understanding technology as a new humanistic ontology, denouncing technology's sinister capability to facilitate "abstract modes of engagement with the world", as argued by Simon Cooper $(2002,51)$.

Even today, postmodern theory is still largely cautious, if not downright sceptical and pessimistic, of technology. Jean-François Lyotard (1977) casts Duchamp's The Bride Stripped Bare by her Bachelors, Even (1915-1923), as the model of a radically different type of machine, a pointless 'bachelor machine', opposed to industrial mechanics and the capitalist system underlying it. Lyotard (1977; 1979) instead wants to reclaim the machine and would happily see it extended to the social realm. This uncomfortable angle is carried forward in Michel Carrouges's (1954) terrifying bachelor machines, understood essentially as instruments of alienation and/or torture, as featured in Edgar Allan Poe and Franz Kafka. More recently, Paul Virilio (1986; 1991a; 1991b; 1994) has also critiqued the cult of technology and 'techno-fundamentalism' he believes are ingrained in contemporary society, relying on pessimistic and apocalyptic tones that are reminiscent of Forster.

Further considerations regarding the theoretical import as well as social impact of technology, are necessary to understand the wider impact of machines. In the nineteenth century technology had been regarded widely as a 
primary agent of social change and progress. Machines were the cornerstones of the Industrial Revolution. In his seminal 1829 essay 'Signs of the Times', the Scottish essayist and historian Thomas Carlyle minted the idiom 'the age of machinery'. Proposing a reading in the negative, Carlyle intended the age of machinery to include the contemporary industrial arts, the empirical philosophy of Locke and Descartes and the hierarchical division of labour brought about by the advent of the machine. Notwithstanding widespread pessimistic stances, "the culture of modernity" is permeated by "a kind of technocratic utopianism", as Leo Marx remarked (Marx 1995, 20).

This 'technocratic utopianism' may well have prompted some of the warmest Futurist embraces with the machine. At the same time, however, the state of industrial modernity in Italy at this time must have acted as one of its propulsive forces, more significantly so than any theoretically informed position. In the first fifteen years of the twentieth century, and more precisely under Giovanni Giolitti's government, Italian industry was undergoing a structural and economic expansion, resulting in robust and unprecedented technological dynamism, fuelling the enthusiasm reflected in the works of the Futurists.

The Great War, of course, further propelled mechanic industry, in means and measures that were unprecedented in Italy at this time (Romeo 1963, 11). However, Italy's embryonic framework, comparatively with other western societies, rendered the pursuit of a machine utopia arguably more problematic, even more imprecise and vague, than it may have been the case in countries already familiar with the Industrial Revolution. It seems, for instance, hardly accidental that a number of Italian Futurists went into forced or voluntary exile, working for extended periods of time outside Italy, in close contact with the technical, economic and logistic facilities provided by industrially advanced societies. Depero, for example, lived and worked for two lengthy consecutive periods of time in New York, between 1928 and the end of the 1940s; Enrico Prampolini lived and worked mainly in Paris between 1925 and 1937; Ivo Pannaggi went into exile to Germany and Norway from 1923; and Vinicio Paladini lived and worked both in the USSR and the USA throughout the 1930s and 1950s.

\section{Marinetti's technophilia}

Unlike other western countries, Italy was yet to experience the employment of technology on a large scale. This relative underdevelopment impacted on the Futurist group, and on Marinetti in particular, whose understanding of technology remained at best, literary and lyrical, and at worst, limited and superficial. For all his vociferous technophilia, Marinetti approached machines in largely formulaic manners. As feared by Forster, the machine became fetishised, 
even sexualised, eschewing direct confrontation, in the words of Shirley Vinall, with its "social, economic and historic context" (Vinall 1985, 85). Evidence of imprecision can also be traced in the Futurist idiom. Here, the tangible, hackneyed term macchine (machines) is usually preferred to the more conceptual tecnologia (technology) or even tecnica (technics). Real, tangible, greased-up machines do not appear to cross the path of the Futurist artist. When they rarely do so, as witnessed in Marinetti's car crash, the interaction between human and the recalcitrant mechanical object is necessarily catastrophic.

Aware of the increasing impact of the new media, and dexterous at seizing opportunities wherever they may arise, Marinetti articulated his position frequently and vocally, alone or in collaboration with his acolytes, from the technology-savvy airplane pilot Fedele Azari, the co-author of a curious manifest 'Towards a Society for the Protection of Machines' (1927), to the poet Pino Masnata, who, in collaboration with Marinetti, drafted the manifest 'The Radio' (1933). However, as several critics have remarked, Marinetti was largely unable to translate his enthusiasm for technology in a competent and first-hand engagement, unlike his eternal rival, the charismatic poet Gabriele D'Annunzio, who not merely drove motorcars competently, but also flew small planes with seemingly effortless elegance (Vinall 1985; Schnapp 1994; Antonello 1999). In short, Marinetti remained wedded to a nineteenth century view of technology, rooted in powerful models drawn from Italian literature, and, equally importantly in the light of Marinetti's background and education, from the French literary tradition.

Italian nineteenth century models include, in particular, the popular poet Giosuè Carducci and his 'monstrous' (in the Latin meaning of technologically wondrous) steam train, satanic harbinger of industrial modernity looming large in celebrated poems such as 'A Hymn to Satan' (1863) and 'At the Station on an Autumn Morning' (1877) in The Barbarian Odes. In French, Marinetti's most influential precursors were the pre-symbolist Paul Adam, Joris-Karl Huysmans's Against the Grain (1884), and, in particular, Emile Zola (Vinall 1985). Born of an Italian family relocated to Egypt at the time of the construction of the Suez Canal, where his civil engineer father gradually amassed a fortune, Marinetti was educated in his native Alexandria at the Jesuit college Saint Francis Xavier. Prone to histrionics since an early age, Marinetti was expelled from school precisely for introducing forbidden works by Zola, as he himself records anecdotally at the beginning of his Critical Writings (n.d.). Zola, whose father was, as Marinetti's, also a civil engineer, may have provided the Italian with the most powerful model of an anthropomorphised and sexualised machine: la Lison, the mechanic, humanised locomotive and protagonist of his 1890 novel The Human Beast. Zola sexualised his locomotive, giving it a female name and enmeshing it with the personal and sexual trajectory of his protagonist, Jacques Lantier. Zola's an- 
thropomorphic and sexualised machine resurfaces audibly in Marinetti's later works, especially in The Steel Alcove, a 1921 war novel redolent with sexual imagery clustered round the iconic image of a war machine, a tank invested by its driver with erotic and patriotic desire.

Even closer to Marinetti's discourse, including the style, is the concurrent poem Prose of the Trans-Siberian and of Little Jehanne of France of 1913, composed by Blaise Cendrars (pseud. of Frédéric Louis Sauser) and illustrated by Sonia Delauney. Written after the opening of the Trans-Siberian line in 1905, a long-distance railway line connecting western Russia with the Pacific coast, the poem celebrates this major feat of modern mechanics and engineering. Built to complement the existing Trans-African and Trans-Andine lines, "the train itself appears to be a microcosm of the international technology of the 1910s: [...] the dizzying wheels churn, the train throbs, the poet invents comically grandiose aviation stories to entertain little Jehanne" (Perloff 1986, 17). Throbbing with sexual energy and appetite, expressed here through the conduit of warfare, Cendrars' train is particularly resonant with Marinetti's own fetishised and sexualised mechanical object, from the motor-car featured in his 'Founding and Manifesto' to The Alcove of Steel.

\section{The Social and Political Machine of Ivo Pannaggi and Vinicio Paladini}

Within Futurism, however, there also emerged positions that were alien, even radically contrary, to Marinetti's own. Some Italian Futurist artists, particularly Paladini and Pannaggi, acknowledged the development and increasing relevance of an industrial context, engaging with the machine's social and political significance. Concrete, as well as first-hand, Pannaggi and Paladini's world view was antipodean to Marinetti's own. Alone amongst Futurists of their age group, Pannaggi and Paladini rejected indiscriminate machine endorsements, such as Marinetti's own, together with the imperialist and belligerent war machines of the fashionable and influential journalists and essayists Alfredo Oriani, Mario Morasso, and Enrico Corradini, as well as the paternalist-socialist machines featured in the novels by Giovanni Cena (Tessari 1973). Despite working as a typesetter in a printing house, Martino Stanga, protagonist of Cena's novel, is largely portrayed as an artist and philosopher manqué, rather than a manual worker. Pannaggi and Paladini, on the other hand, developed a lucid and pragmatic programme that rejected and re-formulated Marinetti's generic and derivative discourse. In firm touch with the technical developments of industrial societies, frequently working in tandem, these two artists devised convincing 
theories rooted in their first-hand experience of factory work and centred on the role played by machines within the social sphere. At once intellectuals and manual workers, both Futurists and socialists, Pannaggi and Paladini disprove the stale, yet surviving, stereotype that sees Futurism as virtually synonymous with Fascism (Stone 1998, 52; Evangelisti 1986, 14; Lista 1995, 180; Berghaus 1996). They go further than any of their Futurist colleagues in conceptualizing machine aesthetics, beginning from their 'Manifest of Mechanical Art' of 1922, and experimenting with concrete applications in the fields of the visual and performing arts.

Born in Macerata in 1901, Ivo Pannaggi was ironically known in the avantgarde circle founded by the Bragaglia brothers in Rome, as 'the Moscovite from the Marche' (Carpi 1981; Lista 1988). The brothers Arturo Bragaglia, Carlo Ludovico Bragaglia and Anton Giulio Bragaglia were versatile avant-garde artists and intellectuals whose wide ranging interests spanned cinema, photography, theatre, and ballet. The Bragaglias were central to the Roman avant-garde movement, especially Anton Giulio who, in 1918, founded and directed the popular Bragaglia Art House, an art gallery and social and recreational space where Balla, Sironi, and the Dadaists, amongst others, exhibited their works. In 1922, Bragaglia founded the equally significant Experimental Independent Theatre, a hub of feverish avant-garde theatrical activity hosting performances by Marinetti, Luigi Pirandello, as well as lesser known, experimental artists. After his Roman experience, and shortly after Fascism's accession to power in 1922, Pannaggi trained at the Bauhaus from 1923. In 1926-27, his visual work became increasingly Constructivist, echoing the works of Malevich, Van Doesburg and El Lissitski. The Bauhaus provided Pannaggi with a platform. From Germany, he moved to Norway, where he worked as an architect and factory worker in Oslo, before retiring to Italy, where he died in 1981.

Vinicio Paladini (1902 - 1971) was born in Moscow of a Russian mother. His Italian father owned and managed several clubs and hotels in Rome, including the renowned Bal Tik Tak decorated by Balla in 1921. Still a teenager, Paladini became involved with anarchist politics. He joined the socialist movement, attending the Roman avant-garde circles more and more assiduously. Paladini came to regard the avant-garde as synonymous with social revolution, on the model of the Bolsheviks and the proletarian art movement Proletkult.

In fact, an article written by one of founders of Proletkult, Alexander Bogdanov, formerly a close collaborator of Lenin and staunch advocate of technology, published by Antonio Gramsci in his periodical Ordine Nuovo in October 1921, made a lasting and fruitful impression on the young Paladini. In this article, entitled 'Proletarian Poetry', Bogdanov argued that the integration between machines and the proletariat witnessed in modern factory work would bring about an anti-bourgeois culture, eventually led exclusively by the workers. 
The Futurists, he further maintained, were to facilitate this process, at least until such time as the proletariat was ready to take over. Paladini embraced Bogdanov's theories wholeheartedly, as testified by his own article on mechanical aesthetics published the following year in the review of the young Italian communist association, the journal Avanguardia. Machines are essential, he wrote, both historically and aesthetically. Machines alone will facilitate and effect collaboration between the working and the intellectual classes, he echoed in a 1923 article published in the socialist journal Pagine rosse (Red Pages) (Carpi 1981, 49, 58).

In June 1922, Paladini exhibited his paintings in a Futurist exhibition in Macerata, organized by Pannaggi. His canvases included The Proletarian of the III International (1922) and The Ninth Hour (1922), portraying the symbiosis between factory worker and machine, in a complex figural conflation where the worker struggles to emerge from the complex clockworks of machines surrounding and encapsulating him like a womb. Regrettably, neither canvas survives. However, this theme is repeated in later canvases dating 1926, such as Departure and Acrobatics. Still with Pannaggi, in June 1922, Paladini devised a Futurist Mechanical Ballet.

This ballet was first staged in Rome, at Bragaglia's theatre. Hardly any testimony remains: the script is lost, the sparse designs for costumes and choreography and extant images documenting the show are damaged or poor quality. Nonetheless, special mention is due to this compelling and influential dramatization of Paladini and Pannaggi's theories. The ballet was centred on the robotic movements of a mechanized man performed by a dancer wearing a mechanical costume designed by Pannaggi. Two professional dancers, the Russians Ivanov and Ikar, took turns wearing the heavy costume. This robot impersonated a factory worker, a hybrid of human and mechanical, a man mutated into the machinery he operates. Moving automatically, under a sheaf of white and multi-coloured lights, on the model of the automatisms afforded by the Taylorian and Fordist assembly lines, this mechanical dance alternated with the similarly robotic movements performed by a dancer impersonating a puppet designed by Paladini (Angelini 1996, 134). The soundtrack was described as a 'polyphony' obtained by two motorcycle engines revving up and down repeatedly, at great risk of gassing the audience tightly packed in the confined and airless space of Bragaglia's theatre.

In its attempt to integrate machine aesthetics with the working classes, indeed to merge machines physically with the workers who operated them, this ballet resonates with contemporary innovations on the European stage. The dancer's body working as a prop, a mere support to the mechanical costume that stiffen and mechanize his movement, is repeated in the contemporary Triadic Ballet by the Bauhaus artist Oskar Schlemmer, also dated 1922. Pannaggi and Paladini's 
ballet predated, and to some extent also arguably inspired, Nikolai Foregger's dance of machines of 1923, Fernand Léger's cubist film Mechanical Ballet of 1924, as well as probably lending ideas to Fritz Lang towards his film Metropolis (1927). In this context, it is worth noting that a similar integration of humans and machines was achieved outside Europe, namely the U.S.A., as demonstrated by popular cultural forms such as the heavy percussion rhythms of big swing bands, in tap dancing, and the Ziegfeld Follies. Technologically advanced societies such as the American one, had sought and practised integration between machine aesthetics and the working classes in the 1920s and 1930s (Dinerstein 2003). Cultural expressions that were extremely popular with the immigrant communities, such as tap dancing and big swing bands, achieved a successful integration, embedding machines in the everyday life of working class Americans.

Compared with Italy's embryonic industrial structure, Pannaggi and Paladini's focus on human-operated machinery was, unlike its American counterpart, not reliant on mechanised cultural forms that were genuinely widespread and popular. Instead, it drew essentially from Marxist theories, and, in particular, from Karl Marx's own emphasis on terms such as 'machines', 'machinery' and 'factory mechanism' (see L. Marx 1995, 26). These 'relics', as Leo Marx puts it, carried significant weight in the recently industrialized Italy of Paladini and Pannaggi's time. In their capacity for re-mapping social hierarchies, machines remained powerfully symbolic of the class predicament and struggle in 1920s Italy. Indeed, machines identified naturally with the proletarian revolution, as highlighted in the 'Manifesto of Mechanic Art', first published in the journal $\mathrm{La}$ Nuova Lacerba in 1922 (Pannaggi and Paladini 1922). This short yet punchy Manifest proposed a militant, indeed revolutionary, machine theory. Moving from the idea of 'modernolatria' (idolatry of modernity), attributed to Boccioni, and following in the footsteps of German and Russian Constructivism, it issued an imperative to embrace the machine, understood as the distinguishing feature of our age. The authors maintain emphatically: "we feel mechanically, we are made of steel, we are machines, mechanized by our age" (Pannaggi and Paladini 1922 , n.p.). These ideas are reiterated visually in the two illustrations included in their manifesto, one of which, designed by Paladini, features a be-goggled human figure, a 'proletarian' striving to emerge from the complex clockwork embroiling his form, a figure strongly reminiscent of the factory workers Paladini featured in his contemporary paintings. 


\section{Paladini's Downfall}

The 'Manifesto of Mechanical Art' could not be further removed from Marinetti's propositions. Threatened by its radical pronouncements and aggressive stance, the Futurist headquarters attempted to neutralise this short text. A year later, they issued a censored version, backdated to 1922, so as to appear contemporary to Pannaggi and Paladini's Manifest, including a preface by Marinetti and a bland attachment drafted by Prampolini, described by Carpi as "a wordy wash-down" (Carpi 1981, 88). This second Manifest, now entitled 'Mechanic Aesthetics', played down the identification between machine and the proletariat. As such, it was approved by Pannaggi alone. Issuing abrasive statements from the pages of radical periodicals, such as Rovente ('Scorching hot') and Pagine rosse ('Red pages'). Paladini not only excommunicated this revised draft, but also denounced the recent alliance forged between the Futurist headquarters and the Fascist movement. The final word rested with the leader of Futurism, Marinetti, who, in 1925, published a further counter-manifest in the periodical L'Impero ('The Empire'). Following Mussolini's accession to power and the authoritarian turn taken by Fascism in 1924, Marinetti's manifest demonstrated the irreconcilable and ever widening hiatus between Paladini's and his own position. The publication of Marinetti's piece signed Paladini's definitive dismissal, virtually forcing him into exile. As an anti-fascist avant-gardist close to socialist and anarchist circles, Paladini became increasingly marginalised. Eventually, he was ostracised, both by fellow Futurists, repelled by his radical ideology, but also by his socialist comrades who regarded his Futurist affiliation as a marker of flagging political integrity. Training as an architect in the late 1920s, Paladini eventually channelled his individual machine work into innovative architectural projects, though unsuccessfully in his homeland, due to the unsympathetic climate of Mussolini's dictatorship.

Paladini's Futurist excommunication failed, however, to diminish his loyalty to machines, as testified by the title of his new venture, the periodical La Ruota Dentata (The Cog-wheel). Factory grease, gears, and cog-wheels continued to inspire and feature in his work extensively. Paladini no longer situated machines within factories, understood as arenas of social conflict. Instead, he re-imagined machines in the markedly different setting of the amusement park, the circus, the recreation park. In short, he became progressively less militant, eventually replacing Marxism with Surrealism and Dada. Paladini's new aesthetic resulted in the two experimental films Traumatic Luna Park (1927) and The Last Enemy, released in the mid-1930s. Neither film survives and very little is known about them, other than that they echoed closely surrealist films of the time, such as René Clair's Entr'acte ('Intermission', 1924) and Buñuel and Dali's L'Âge d'or ('The Age of Gold', 1930). 
Paladini's machines were therefore destined to be useless, preparing the ground for the playful and carefree macchine inutili ('useless machines') of Bruno Munari (1907-1998). An architect and interior decorator, as well as former Futurist, Munari devised a long series of useless machines throughout his career, beginning from the 1930s. Moving from Duchamp's ironical and unproductive Large Glass, as well as from a plea for leggerezza ('lightness') resonating also in Italo Calvino's prose a few years later, Munari aimed to turn machines into useless and uncommercial art objects. Paladini would arguably have taken a similar direction, had he not re-directed his art in utopian architectural projects that were destined to fail, receiving no backing from the authoritarian state. Working in this frame, Paladini met some success in the U.S. in the late 1940s and early 1950s, but was nonetheless forced to repatriate to Italy under President McCarthy's anti-communist witch-hunt. Even though his radical political experience met a brutal end, there is little doubt that Paladini's imaginative mechanical art had a powerful, if indirect, impact on Futurism's attempt to hybridize visual art and science, both in Italy and internationally.

One of the last incarnations of Futurism, dated approximately 1930-1950, and known as Aero-futurism, failed to engage convincingly with machines. Artists such as Prampolini, Fillia (pseudonym of Luigi Colombo) and Tullio Crali pursued a disengaged machine aesthetics consisting predominantly of a 'cosmic', 'spiritual', and 'mystical' view of flying machines. Their intellectual stance encapsulated much of the starry-eyed infatuation with the technology of flying that was increasingly creeping into the public sphere. The air show was the most technologically advanced and spell-binding spectacle of the day (Schnapp 1994; Wohl 2005). As could be expected, Pannaggi and Paladini loathed Aerofuturism and steered well clear of it. Their objection was aesthetic but, principally, ideological. Machines may still be central within Aero-futurism, but neither in the mythical and erotic sense understood by Marinetti, nor in the social and political sense understood by Paladini and Pannaggi. Machines no longer seemed to raise apocalyptic fears as the ones embedded in Forster's story 'The Machine Stops' that I cited in the introduction. Backed up by the Fascist regime's substantial investments in the aviation industry, Aero-futurism concentrated instead on heightened individual sensitivity and the changes brought about by the new technology of flying in the individual experience and perspective of the viewer. The spiritual thirst for heavenly infinities of the individual artist and viewer were to prevail over the pursuit of a collective machine utopia. 


\section{Conclusion}

Starting from the views on the relation between society and technology in official Futurism and, especially, in the writings of Marinetti, this article then focused on the less-known mechanical artistic production of Pannaggi and Paladini. Alone within the post-war Futurist avant-garde, these two artists both devised and circulated a first-hand and lucid conceptualization of machine aesthetics, although they leaned partially on Constructivism. Achieving the goal of embedding machines in the social and political arenas of their time, Pannaggi and Paladini's view is lucid and persuasive. Such precise and coherent statements are alien to Marinetti's own reflections on machines. Relying on hackneyed nineteenth century models and failing to acknowledge the machine's social and economic reality, Marinetti's Promethean, fetishised, and sexualised machines do not pose a persuasive alternative. The relationship between man and machine is not resolved by Marinetti, whose prose, redolent of sexual attraction, betrays latent fear and alienation. Socially and politically embedded, Pannaggi and Paladini's stance is, in my view, a far more convincing and enduring herald of achieved cyborg alliances.

\section{Bibliography}

Angelini, F. 1996. Teatro e spettacolo nel primo Novecento. Rome-Bari: Laterza.

Antonello, P. P. 1999. On an Airfield in Montichiari, Near Brescia. Staging Rivalry Through Technology: Marinetti and D'Annunzio. Stanford Electronic Humanities Review 7.1, http://www.stanford.edu/group/SHR/7-1/html/antonello.html (accessed June 22, 2007).

Berghaus, G. 1996. Futurism and Politics: Between Anarchist Rebellion and Fascist Reaction, 1909-1944. Providence, RI and Oxford: Berghahn Books.

Berghaus, G. 1998. Italian Futurist Theatre. Oxford: Clarendon Press.

Carpi, U. 1981. Bolscevico immaginista: Comunismo e avanguardie artistiche nell'Italia degli anni venti. Naples: Liguori.

Carrouges, M. 1954. Les machines célibataires. Paris: Arcanes.

Cigliana, S. 2002. Futurismo esoterico. Naples: Liguori.

Cooper, S. 2002. Technoculture and Critical Theory. In the Service of the Machine? London \& New York: Routledge.

Dinerstein, J. 2003. Swinging the Machine: Modernity, Technology and African American Culture between the World Wars. Amherst: University of Massachusetts Press.

Evangelisti, S., ed. 1986. Fillia e l'avanguardia futurista negli anni del fascismo. Milan: Mondadori-Daverio.

Forster, E. M. 1984. The Machine Stops. In Collected Short Stories. Harmondsworth: Penguin, $109-46$. 
Heidegger, M. 1977. The Question Concerning Technology and Other Essays. New York: Harper and Row.

Lista, G. 1988. Dal Futurismo all'Immaginismo. Vinicio Paladini. n.p.: Il Cavaliere Azzurro.

Lista, G. 1995. F.T. Marinetti: L'anarchiste du futurisme. Paris: Séguier.

Lyotard, J.F. 1977. Les transformateurs Duchamp. Paris: Galilée.

Lyotard, J.F. 1979. La condition postmoderne: rapport sur le savoir. Paris: Minuit.

Macchina Monstrum del Moderno, La. http://www.inventati.org/owatta/cpm/mmm.pdf, 1-48. (Accessed March 18, 2008).

Marinetti, F. T. 1973. Futurist Founding and Manifesto. In Futurist Manifestos, ed. U. Apollonio, 19-24. London: Thames and Hudson.

Marx, L. 1995. The Idea of 'Technology' and Postmodern Pessimism. In Technology, Pessimism, and Postmodernism, eds. Y. Ezrahi, E. Mendelsohn, and H. Segal, 11-28. Amherst: University of Massachusetts Press.

Masoero, A., R. Miracco, and F. Poli, eds. 2004. L'estetica della macchina: da Balla al futurismo torinese. Milan: Mazzotta.

Pannaggi, I. and V. Paladini. 1922. Manifesto dell'arte meccanica futurista. La Nuova Lacerba. June 20, N.P.

Perloff, M. 1986. The Futurist Moment. Avant-Garde, Avant-Guerre, and the Language of Rupture. Chicago and London: University of Chicago Press.

Romeo, R. 1963. Breve storia della grande industria in Italia. Bologna: Cappelli.

Schnapp, J. T. 1994. Propeller Talk. Modernism/Modernity 3: 153 - 78.

Spengler, O. 1922. The Decline of the West. London: Allen and Unwin.

Spengler, O. 1931. Man and Technics. n.p.: Allen and Unwin.

Stone, M. S. 1998. The Patron State: Culture and Politics in Fascist Italy. Princeton, NJ: Princeton University Press.

Tessari, R. 1973. Il mito della macchina. Letteratura e industria nel primo Novecento italiano. Milan: Mursia.

Vinall, S. 1985. The Emergence of Machine Imagery in Marinetti's Poetry. Romance Studies 6: 78-95.

Virilio, P. 1986. Speed and Politics: an Essay on Dromology. New York: Semiotext(e).

Virilio, P. 1991a. The Aesthetics of Disappearence. New York: Semiotext(e).

Virilio, P. 1991b. The Information Bomb. London: Verso.

Virilio, P. 1986. The Vision Machine. London: B. F. I. Press.

Wohl, R. 2005. The Spectacle of Flight. Aviation and the Western Imagination 1920-1950. New Haven and London: Yale University Press. 


\section{Philosophical Interlude}


Open-Access-Publikation im Sinne der CC-Lizenz BY-NC-ND 4.0 (C) 2010, V\&R unipress GmbH, Göttingen 


\section{Rosi Braidotti}

\section{Chapter 4: The Posthuman Predicament}

\section{Introduction}

In order to sketch a definition of the posthuman, a number of critical parameters need to be established at the outset. The posthuman predicament, not unlike other illustrious examples of 'post' notions, implies both a chronological and a conceptual aspect. Thus a posthuman turn can only come after and build upon the legacy of the critical insights and the theoretical problems initiated by the postmodern and poststructuralist generations throughout the 1970s and 1980s. This basic sense of chronological continuity is necessary in order to establish some of the defining features of posthuman thought. It is not, however, sufficient in itself. In this essay I want to argue that one of the driving forces of the posthuman turn is precisely a conceptual revision of some of the core features of poststructuralist thought. Whereas poststructuralism was based on a linguistic frame of reference and on symbolic mediation - especially in the work of Lacan and Derrida - posthuman thought returns to the materiality of the body and the primacy of life itself. By implication, issues related to identity and identitarian politics are replaced by a new emphasis on impersonal and even a-personal interconnections and networks of relations.

This shift of perspective is relevant to the theme of this volume in so far as it relocates science and technology in the centre of the philosophical discussions about subjectivity. The main reason for this fundamental relocation is the challenges that have been thrown towards received notions of what constitutes the basic unit of reference for 'the human'. Whether we approach this issue from the angle of the contemporary biogenetic and information technology revolution, or whether we take the line of human rights and the destitute masses engendered by globalization, the posthuman turn forces upon us a reconsideration of the human itself.

As a result, whereas postmodern cultural critique and poststructuralist theory took their clues from and set their priorities round semiotic studies of popular culture, film and media, the forum for discussions on the posthuman is 
set by science and technology studies. Posthuman theory differs, however, from science and technology studies of the previous generation in engaging fully with the question of the subject, contrary to the anti-subjectivity stance taken for example by Latour's Actors Network Theory (2005). Subjectivity matters all the more in the light of the ethical and political issues raised by the power differentials and structural inequalities of our technologically mediated globalized world. In this respect, posthuman theory is less anti-foundational than its predecessors and introduces a strong ontological element.

Yet, the prefix 'post' is not a normative injunction and even less so in the case of the posthuman: it does not establish new targets, norms or desiderata. As an analytical tool, the posthuman turn is an attempt to account for the swift transformations of our historical conditions. As an inspirational concept, it invites us to stretch the boundaries of critical thought at a time of great transformations of the human within and without the individual, bounded self. Today more than ever, the 'life' we inhabit escapes the control of the single self, just as we - as a scientific culture - have managed to increase our cognitive mastery over the biogenetic codes of living matter. This is the paradox I will address in the second half of my essay, but first I will sketch the philosophical background of the posthuman turn, starting from a critique of the classical view of the human in humanism and moving to a new, post-anthropomorphic, view of the posthuman. Central to those discussions is the self-other relationship: who is the other of the human; and who is the other of the posthuman?

\section{The Anti-Humanist Legacy of Poststructuralism}

The term posthuman indicates that it has a different view than before on what constitutes the human, which means that it has undermined the humanistic view of the human subject. It is mostly the poststructuralist generation that bequeathed upon us incisive critiques of the liberal individualist vision of the humanist subject. This critique developed into a twofold project: a) attacking the basic tenets of classical humanism and b) targeting the residual humanism of allegedly radical theories such as Marxism and psychoanalysis.

In the first case poststructuralism criticized classical humanism for its vision of the subject as coinciding with rationality, universal moral agency, and selfregulating consciousness. These qualities and prerogatives came under critical scrutiny because of their exclusionary social applications and discriminatory implications. Thus, according to poststructuralist thinkers like Foucault and Irigaray, the humanist subject defines himself both by appropriating these qualities as his own entitlement, and by excluding a significant proportion of 'others' from gaining access to them. Projecting upon others pejorative differ- 
ence or negative otherness is consequently standard practice for the humanist subject: women, natives, machines, animals, and the earth are constructed as others who are necessarily excluded from the status of subject. The critical epistemologies since the 1970s single out the regulatory violence that is implicit in this hegemonic vision of the subject (Foucault 1966), as well as his phallocentrism (Lacan 1998), his Eurocentric bias (Said 1978; Spivak 1999) and his virulent patriarchal heterosexism (Irigaray 1974; Wittig 1992).

This takes us to the second aspect of the anti-humanist position: the charge that seemingly radical philosophies of the subject, such as Marxism and psychoanalysis - Marx and Freud revisited by Althusser and Lacan - continue to be related to humanism, albeit it by negation. They rely on a dialectical model for the constitution of the subject and hence also for the self-other relation, for which traditionally the three main embodiments of otherness are gender, race and nature. Again, Foucault's work (1975) on the links between reason, rationality and power and governmentality is essential to this debate. Poststructuralist philosophy produces a socially aware and politically infused rejection of humanism, which connects the practice of reason to the sovereign rule of dominant powers.

Poststructuralist anti-humanism, in a variety of forms that range from feminist theories to postcolonial theory, targets the implicit assumptions about the human that structure so much allegedly radical discourse. The tactics are as varied as the alternatives they propose: the feminists expose the androcentric, phallogocentric aspects of this notion of the human, arguing that it collapses masculinity with a falsely universal definition of 'Man' as the measure of all things (Lloyd 1985; Harding 1986; Griffin and Braidotti 2002). This image inflates the masculinised human and makes him coincide with a vision of rational self-reflexivity that is best expressed in the language and the practice of science and scientific reason. This standard vision of the human had been posited in a universal mode as Man, but this pseudo-universal has been widely criticized precisely because of its partiality (Fox Keller 1995). Universal Man, in fact, can be disclosed as the masculine, white, urbanized, speaking a standard language, heterosexually inscribed in a reproductive unit and a full citizen of a recognized polity (Deleuze and Guattari 1980). Anti-racism, postcolonial and race studies move in the same direction, exposing the white supremacist assumptions of the humanist idea of 'the human' (Hill Collins 1991; Gilroy 2000; Ware 1992). They challenge this profoundly Eurocentric vision of the subject and the virulent forms of ignorance of others that it engenders.

The poststructuralist critique of the human subject thus brings with it a new paradox: in repudiating the classical view of the human subject, it opened up more radical views that undermine even further the humanist stance. Under the cover of a master theory of historical materialism, or with the psychoanalytic 
theorization of the unconscious, the idea of the subject continued to be subjected to the regulating powers of universal reason. This assumes a unitary faculty of judgment, a hegemonic use of rationality, and the notion that the subject of knowledge is somehow in charge of his own (the gender is no coincidence) and of world history. This is then still a hegemonic view of the human subject, which needs to be destabilized by philosophical anti-humanism as it is developed in feminist, postcolonial and anti-racist theory. They free it from such universalizing postures by bringing to the surface the hidden power relations and the fantasies that sustain it.

\section{From Anti-Humanism to Post-anthropocentrism}

No sooner was this radical agenda partially acknowledged and discussed inside and outside the academic world throughout the 1980s, that a second and even more devastating attack on the notion of the human emerged through the compounded impact of globalisation and its technology-driven forms of mediation. Central to the dislocations induced by globalised culture is the convergence between different and previously differentiated branches of technology. Biotechnologies and genetic engineering on the one hand and information and communication technologies on the other are equally active in producing the spectacular effects of contemporary technological transformations. The biogenetic structure of contemporary capitalism profits from the control and the commodification of all that lives: the capital is the genetic code itself. This means that all species are implicated in advanced genetic engineering for the sake of research, development and profit.

The political economy of bio-genetic exploitation causes a phenomenon also known as 'biopiracy' (Shiva 1997). The distinction between the human and other species is erased when it comes to profiting from them: cells, seeds, plants, animals and bacteria fit into this logic of insatiable consumption of life itself. Thus, the categorical distinctions between animals, vegetables and humans collapse, resulting in a generic displacement of the centrality of the human (Haraway 2003). A post-anthropocentric shift takes place that encompasses not only the humans' relation to other species, but also the sustainability of our existence as a human species on this planet as a whole. The self-other relationship therefore radically changes, as the other now encompasses the earth or 'life itself' (Rose 2001). The emergence of the earth as a political agent opens up a planetary level in contemporary cultural geopolitics (Guattari 1992; Haraway 1997; Spivak 2003).

Advanced capitalism produces a global posthuman condition - in the sense of post-anthropocentrism - because it is a system that actively produces and cir- 
culates hybridity and transversal connections. These erase the qualitative lines of demarcation not only among categories such as male/female, black/white, human/animal, dead/alive, centre/margin, etc., but also within each one of them (Braidotti 2006). Postmodern critiques of representation and poststructuralist analyses of power as discourse had previously argued that advanced capitalism is a 'difference engine', that is to say a multiplier of differences, which are then packaged and marketed under the labels of cultural and social pluralism. The posthuman turn changes the scale of the problem by arguing that globalisation produces pluralism in the form of a multiplicity of centres in a world of scattered hegemonies (Kaplan and Grewal 1994). These proliferations are merely quantitative and hence they hardly change the structure of the power relations. The impact of globalised technological mediation is such that it triggers a ruthless consumption of 'otherness' in contemporary social and cultural practices. From fusion cooking to world music, the consumption of differences is a dominant contemporary cultural practice. In her analysis of the new organic food industry for example, Jackie Stacey (2000) argues that we literally eat the global economy, while Paul Gilroy (2000) reminds us that we also wear it, listen to it and watch it on our many screens, on a daily basis.

In this post-anthropocentric world, the human has been subsumed into global networks of control and commodification which have taken 'Life' and living matter as target. Science and technology, far from being tools of human emancipation and progress, are the leading forces behind this massive overturn of the basic tenets of both humanism and anthropocentric world views. It is no wonder then that we are confronted by a constant state of crisis, such as the crisis of human rights, of human values, bioethics, the environment and sustainability. As a matter of fact, the generic figure of the human itself is in trouble. Donna Haraway puts is as follows:

Our authenticity is warranted by a database for the human genome. The molecular database is held in an informational database as legally branded intellectual property in a national laboratory with the mandate to make the text publicly available for the progress of science and the advancement of industry. This is Man the taxonomic type become Man the brand $(1997,74)$.

That is to say that the transcendental structure of the Human and all the epistemic and cognitive privileges it entails, have been replaced by a rather utilitarian and instrumental approach to the genetic material provided by the embodied human subject.

Brian Massumi refers to this phenomenon as 'Ex-Man': "a genetic matrix embedded in the materiality of the human" $(1998,60)$. The Human has thus lost its integrity and has come to stand for the generative vulnerability of human 
matter. This loss of metaphysical privilege by the human results on the one hand in a sort of ontological insecurity and nostalgia for the lost sovereign position and on the other in a colossal hybridisation with other species. These effects can be seen as two faces of the same coin: a sort of "anthropological exodus" from the dominant configurations of the human we have inherited both from classical humanism and the residual humanism of Marxism and psychoanalysis that I discussed above (Hardt and Negri 2000, 215). It is interesting to note that postanthropocentrism is especially thriving in popular culture, propelled by the postmodern gothic, science fiction, horror and other genres that fuel what I have called the 'techno-teratological' imaginary of our societies (Braidotti 2002, see also the chapters of Merzagora and Smelik in this volume).

In surveying the posthuman predicament of today we can see that it does not function in a linear manner, but that it is rather web-like, scattered and polycentred. The notion of the posthuman is sustained by internally contradictory processes, the effects of which are differentiated geopolitically and along gender and ethnicity lines, to name only the main ones. This creates a few methodological difficulties for the social and cultural critic, because it translates into a heteroglossia of data, rendering both classical and modernist social theories inadequate to cope with the complexities of contemporary society. The paths of transformation engendered by the biogenetic, non-anthropocentric structure of advanced capitalism are neither straight nor predictable. They rather compose a zigzagging line of internally contradictory options. In my view, non-linearity is a major tool to develop cartographies of power that can account for the paradoxes and contradictions of the era of globalisation, without taking shortcuts through its complexities. In the following section I will explore the ethical path of understanding the self-other relationship in the posthuman predicament differently: how can we understand the human when its body is simultaneously caught in the spinning machine of multiple differences and has become a disposable commodity in late capitalism? And how can the human, or rather posthuman, still be an agent for political and ethical transformation?

\section{The Posthuman Politics of 'Life'}

In the second half of this essay I will explore the ethical and political consequences of the posthuman turn, in a perspective that I call 'new materialism' or 'non-essentialist vitalism'. Let me start by stressing that the posthuman condition clearly displays inhumane features in that it introduces ruthless power relations. Globalisation encompasses many dire aspects, such as the increase in poverty, especially among women, the disparity in access to the new technologies, world migration and massive human mobility. While science and 
technology may have increased health and produced cyborgs and cyborg-like bodies, there are also renewed forms of vulnerability for the human body. For example, epidemics have returned in the form of Ebola, TB, and HIV - so much so that health has become a public policy issue as well as a human rights concern. Depression and burnout are larger phenomena than ever and eating disorders affect over one third of the youth in wealthy countries. Wars and the uprooting of millions of people who turn into stateless asylum seekers are constant features of our social landscape. These issues deserve more space than I can grant them in this article.

Here I want to focus on the management of 'life itself' as a marketable commodity in a post-anthropocentric mode, which has taken centre stage in the political economy of advanced capitalism (Rose 2001). This includes the proliferation of practices, both scientific and social, which go beyond human life and are transversal to species and to generations. A phenomenon like Dolly the sheep is central to this discussion: neither truly animal, nor totally machine, she is the head of a new species without a progenitor (Franklin 2007). Alone of all her kind, she is mother to herself but also the product of a virgin birth. In other words, all time sequences get scrambled in the production of the non-reproduced entity that is Dolly. The mutual interdependence of bodies and technologies creates a new symbiotic relationship between them, which necessitates and encourages a radical critique of anthropocentrism in favour of the recognition of the entanglement of material, biocultural and symbolic forces in the making of both human and non-human subjects.

Contemporary genetics and biotechnologies are central to the end of temporal linearity and to the shift towards posthuman ideas of 'Life'. I refer to nonanthropomorphic life as 'Zoe' (Braidotti 2006). In my definition, Zoe is the 'other' of the anthropomorphic subject in its humanistic definition. It signifies the generative vitality of non- or pre-human or animal life and it consequently opens up to a new, materialist, understanding of life, of the human, and of the body. More importantly, it also forces a re-consideration of the interaction between the human and the non-human life. Primary among the non-human are the technologically mediated self-organizing structures of the intelligent machines that mark our era. Consequently, science and technology are endemic to contemporary posthuman reflections on issues such as agency, relations and the structure of the subject.

If we extend this analysis to cover the biogenetic area of research and its multiple technological applications - ranging from stem-cells to genetically modified food and everything in between - we can only conclude that contemporary scientific practices have forced us to touch the bottom of some nonhumanity that inhabits the human precisely in the immanence of its bodily materiality. With the genetic revolution we can speak therefore of a generalized 
'becoming infra-human' of life as a vital principle of technologically-enhanced, self-organizing matter. The category of 'life' has accordingly cracked under the strain, introducing new degrees of complexity in our understanding of living matter. The advanced and sophisticated level of biogenetic knowledge is the main factor in producing a posthuman turn in the ways we live and think about ourselves. The question now is whether philosophical, cultural and social theory can live up to this posthuman challenge (Haraway 1997; Halberstam \& Livingstone 1995; Hayles 1999).

Let me explore this query by relating it again to the self-other relationship. We have seen that in classical humanism the other has always functioned as the embodiment of difference that holds up the self in a dialectical relationship. Traditional dialectics tied self and other in an infernal embrace of mutual and resentful dependence, marked by varying degrees of familiarity between the centre and the margins. This intimate and projective relationship is framed by the dominant human masculine habit of taking for granted free access to and the consumption of the bodies of others. In the posthuman predicament of today this mode of relation is being re-set and re-structured. The previously dialectical relationship between self and other has become dislocated and redistributed along a rhizomatic, or multi-layered axis, in contrast to a dualistic axis of opposition. Now that complexity replaces dialectics, it causes the other to lose its metaphysical function of being the binary and specular opposite of the self. By extension, the other ceases to be the privileged term that indexes the European subject's relationship to discursive, social and symbolic power. The posthuman turn in its post-anthropocentric mode encourages us to engage in a radically other relationship with others (Ansell Pearson 1997). The challenge today is therefore how to deterritorialize, or nomadize the self-other interaction, so as to bypass the metaphysics of subjectivity and its corollary, the dialectics of otherness.

As a result, the three main dialectical axes that used to constitute otherness according to the unitary subject of classical humanism - gender, race, nature have shifted. With it the hierarchical scale of pejorative differences has also lost much - but not all - of its nasty sting. Now that the others are not merely the markers of exclusion or marginality, they have become the sites of powerful and alternative subject positions. The posthuman turn has allowed the other to be a decisive agent for political and ethical transformation (Braidotti 2002). The transformation of the axes of sexualised, racialised and naturalised differences forms intersecting patterns of change. As such, there is a new political economy of otherness which is of great ethical and political relevance to posthuman theory. Paradoxically enough, however, the relocation of otherness along a rhizomatic web of multiple differences seems to leave the century-old forms of sexism, racism and anthropocentric arrogance miraculously unscathed. 
Within the context of the subject of this book on science and technology, I want to focus here on the transposition of non-anthropomorphic or Earth others. The critique of anthropocentric thought poses a number of conceptual, methodological and practical complications. My suggestion is to recast the self-other relationship in terms of 'becoming', a concept that I take from Deleuze and Guattari $(1972 ; 1980)$ which refers to a constant process of transformation. The key notion here is that, as embodied and embedded entities, we humans are all part of nature, even though philosophy continues to claim transcendental grounds for human consciousness. Posthuman thought contests the arrogance of anthropocentrism and strikes an alliance with the productive force of Zoe - or life in its inhuman aspects. Thus, affinity for Zoe is a good starting point for what may constitute the last act of the critique of dominant subject positions, namely the return of animal, or Earth life in all its potency. The breakdown of species distinction between human and non-human as well as the explosion of Zoe power shift the grounds of the problem of the breakdown of categories along the axis of gender and race.

This recasts the political project of becoming into a planetary or worldwide dimension, the earth being not one element among others, but rather that which brings them all together. One way to come to terms with this challenge, then, is to emphasize the materially grounded and transformative processes of becoming. This is how I understand vitalism in the context of contemporary biogenetic sciences: the potency of multiple, self-organizing organisms, most of which are technologically mediated, from Dolly the sheep to multiple digital avatars, without forgetting genetically modified food, test-tube babies and complex information and communication technology networks. Central to the posthuman turn as I see it is the impact of material vitalism, or vitalist neo-materialism: Zoe-driven practices of non-human life forms.

\section{The Non-Human as Becoming-Planetary}

The materialist and vitalist perspective need not trigger the cognitive and moral panic that often affects humanistic-minded philosophers, Habermas' (2003) anxiety about the future of human nature being a case in point. On the contrary, the technologically mediated vitalist materialism of our times can both support and be strengthened by a non-unitary and post-identitarian vision of the subject. Complexity needs to be written in the inner structure of subjectivity itself, dispelling any residual notion of metaphysical unity so as to come to terms with the generative power of non-human and non-organic entities.

The biotechnical revolution of today entails by extension a redefinition of evolution in a distinctly less anthropocentric and less deterministic manner than 
most would expect. For instance, in his critique of the rhetoric of biotechnological vitalism Ansell Pearson (1997) warns us against the pernicious fantasy of a re-naturalized evolution led by biotechnological capitalism. He sees this as one of the master narratives of neo-liberalism and as a serious error in the assessment of our historical condition. The paranoid mode of presenting a totalising techno-future perpetuates the split between biogenetic non-human 'Life' and the human. This dichotomous opposition expresses the fear of loss of cognitive mastery by the human subject. The challenge is rather to rethink evolution in a non-deterministic but also a non-anthropocentric manner. Central to this non-essentialist vision of vitalism is the idea of transversal organizations of species and life-forms. These lines of interconnections among disparate organisms - human bodies, technological implants and plants - create a unity that is based on the affinity among different forces. Complexity being the operative word, this affinity is not a synthesis in any totalising sense of the terms. What we get instead is a set of connective disjunctions and productive unfoldings which bring about a recomposition of the matter in question.

In my view, a combination of organic and inorganic material, inherited and acquired, embodied and technological, lies at the heart of a posthuman system that works by flows, movements and self-organizing entities. This 'matter' is thus a biogenetic living entity. The hybrid structure of this matter provides a combination of vitalism and machinism, resulting in a redefinition of each term. At the heart of contemporary computational culture we shall thus find a hightech brand of neo-materialism, which we also know as 'intelligent machines'. This intelligence however, is not only cognitive, but mostly generative, in the sense that it is a form of complex self-organisation. Katherine Hayles' (1999) work on embodiment is part of this movement, which she aptly calls the posthuman life of codes and computing systems. How to reconcile bodily spaces and experiences with the possibilities afforded by the new computational technologies is at the heart of what Hayles describes as 'humanistic informatics'.

The new task for the philosopher or cultural critic is then to redefine the middle ground ('milieu') between entities that were previously defined by binary opposition: organic/inorganic; born or reproduced versus made or produced; biology and technology. The new middle terrain assumes a flat transversal kind of thinking, as opposed to hierarchical ontology. This is also known as 'biocentered egalitarianism' (Ansell Pearson, 1997), in that it posits the necessity of transversal, trans-species interconnections. By re-thinking the middle terms of the relation, posthuman theory forces a re-appraisal of relationality itself. Liberated from the hegemony of anthropocentrism, critical posthuman theory redefines not only the terms of former oppositions and hence the meaning of the human, but also the terms of their interaction.

In the remaining sections of this chapter I shall consequently address the 
paradox I outlined in the introduction, namely the extent to which scholarship on 'Life' bypasses knowledge about the superiority or even the specificity of the human. 'Life' is more than the single life of a defined and bounded self. Therefore the basic unit of reference for the function of subject of knowledge is no longer the defined and actualised human self. I want to argue instead that a transversal vision of subjectivity is best suited to the challenges of a post-anthropocentric vision of the subject. In the following I will give some examples of these interrelated redefinitions and their productive contributions to our understanding of the relationship to contemporary science.

\section{Chaosmosis}

In borrowing the neologism of 'chaosmosis' from Joyce's Ulysses, Deleuze and Guattari (1980) defend a transversal, posthuman vision of the subject as a selforganising and relational entity. The concept of chaosmosis allows us to understand the vital autonomy of material evolution in terms of the specific practices of self-organizing machinic production.

Chaosmosis can be defined as the radical immanence of life as a complex system, which bridges the divide between production and reproduction, machinic and generative powers, technology and biology. Concepts like 'chaosmosis', 'radical immanence' or 'becoming-Zoe', occupy the middle ground between old and classical dichotomies like organic and inorganic matter, and hence they add subtlety to the definition of life. Posthuman theory consequently allows for a complex and hence more adequate theoretical but also practical understanding of the topology and the ethology of forces involved in the evolution of life.

An other key term, adapted from Maturana and Varela (1972) is 'autopoesis', or process-oriented ontology. Machinic autopoesis means that the biogenetic recomposition of life forces and productive machinic processes constitute living matter by a variety of means, not all of which are simply inherited from our own species. Therefore the reproduction of life is a site of becoming, or the threshold to many possible worlds. In my own work I have referred to this processual ontology as 'nomadic becoming', with special emphasis on the productive, gratuitous and non-profit force of the process (Braidotti 1994). Humans need to review their schemes of representation of both the machinic processes and the idea of evolution by updating their appreciation of contemporary biogenetic sciences.

The assumption is that, as stated before, the subject does not coincide with the rational consciousness of a single individual, but rather rests with dynamic flows of multiple interactions. The subjects' fundamental aspiration is neither to make 
sense of life, that is to say to emit meaningful utterances within a signifying system, nor is it about discipline and conformation to ideal models of behaviour. The subject merely aims at self-actualisation, which means achieving singularity. An important new factor enters philosophy here, as Deleuze and Guattari were inspired by Spinoza, and that is: affect. The subject is an enduring, relational entity capable of affecting and of being affected by a multiplicity of others. As subject-in-becoming, s/he is a vector of subjectivation. Subjectivity for Guattari (2000) is 'pathetic' in the sense of empathic, affective, multiple, mediated and complex.

To understand such a transversal view of the posthuman subject we need to approach it through his/her three fundamental ecologies: that of the environment, of the socius, and of the psyche (Guattari 2000). More importantly, we need to create transversal lines through all three of them. It is crucial to see the interconnections among the greenhouse effect, the status of women, racism and xenophobia, and frantic consumerism. We must not stop at any fragmented portions of these realities, but rather trace transversal interconnections among them. In the culture of advanced capitalism, this complexity is misread and reduced to a logic of discourse where capital becomes the referent for labour and 'Being' becomes the great principle of reduction of the ontological multiplicity of transversal life.

Guattari argues that a qualitative step forward is necessary if we want subjectivity to escape the regime of narcissism and paranoia that is induced by advanced capitalism, through social processes of self-withdrawal, infantilisation through media information overload, and the fear or denial of alterity. A virtual ecology of posthuman transformations is necessary to engender the conditions for the creation and the development of unprecedented formations of subjectivity. Another term for it is 'ecosophy', which refers to the kind of thought that aims at crossing transversally the multiple layers of the subject, from interiority to exteriority, and everything in between. These flows of transversal connections are also found in Deleuze's notion of becoming, which can be understood as a process of differentiation and singularisation.

Guattari's scheme of the three ecologies provides an answer to the question of how to conceptualise the transversal interconnections among the lines of definition of different species. Guattari's answer involves a mixed semiotics combining the virtual (indeterminate) and the actual (determinate) domains of life. The non-semiotic codes, like the DNA or any genetic material, intersect with semiotic processes in a complex transversal assemblage of affects, and embodied practices and experiences. Parisi (2004) draws a convincing parallel between chaosmosis as autopoietic becoming and the new epistemology of Margulis (1995). She introduces here the concept of 'endosymbiosis', which like autopoesis, indicates a creative form of evolution. The vitality of matter is defined as 
an ecology of differentiation, which means that the genetic material is exposed to processes of non-linear becoming. This questions any ontological foundation for difference while avoiding the binary oppositions of social constructivism. The project is sustained by the assumption of Spinozist monism, which defines nature/culture as a continuum that evolves through variations or differentiations.

The punch line of this dense argument is twofold. The first point is that difference emerges within a continuum of creative evolution as pure production of processes of becoming. The transitions are internal to the constant process of formation and transformation, which are intensive or affective variations that produce semiotic and a-semiotic practices (Massumi 2002). In Deleuze and Guattari's (1980) work these variations of intensity in space-time are also expressed in the concept of the Body-without-Organs, with which some readers may be familiar. The second point is that priority is given to the relation over the terms. Parisi expresses this in Guattari's language as 'schizogenesis', by which she refers to the affective, relational being of the middle ground, the interconnection, the 'milieu'. The emphasis on the micropolitics of these relations results in a posthumanist ethics that traces transversal connections among material and symbolic, concrete and discursive lines or forces.

Transversality therefore actualises bio-centred egalitarianism as both an ethics and also as a method. This helps us to account for both material and immaterial forms of labour subjectivity in the age of late high-tech biocapitalism, which trades in all that lives and breeds. An ethics that is based on the primacy of the relation and on interdependence, however, values Zoe in itself. Deleuze and Guattari's transversal becomings and chaosmosis offer a relevant alternative to the more conventional discourses about the tensions between technology and biology. By focussing firmly on the middle ground of these relations, Deleuze and Guattari propose an eco-philosophical answer to the paradoxes of our biogenetic era.

\section{Becoming-world, or social sustainability}

In the last section I will further explore this eco-philosophical aspect, by focussing on the notion of 'becoming-world'. The becoming-world means to merge with the environment, or the Earth, as a multiple form of becoming, which is not based on the mere overcoming of a binary opposition (like the becomingwoman, that undoes phallocentrism; or the becoming-nomad, that undoes Eurocentrism). According to Deleuze and Guattari (1972; 1980), it is the only form of becoming which is qualitatively at a distance from the standard or norm of the dominant subject position or 'Majority' as they call it. As such it has the 
power to de-territorialize the Majority and its main categories and classifications. Becoming-world is then a qualitative shift that is immanent to all the others, concerning the movement of the totality of all that lives, of that great animal/machine that is the cosmos itself and the planet as a whole. In this sense, the becoming-world traces a general eco-philosophy of becoming that produces positive interconnections on a planetary scale. The process of becoming-world involves multiple ecologies of belonging.

The question is how we can achieve such a transformation: how to recompose some sense of pan-humanity amidst the scattered hegemonies and power differentials of globalisation? How can we think accurately about the complex singularity of the subject while taking into account the biogenetic materiality of our planetary interconnections? The phrase 'we are in this together' accurately sums up the global dimension of the problems we are facing when we take the power relations of bio-capitalism as the defining feature of our historicity.

I argued above that one of the consequences of the posthuman predicament is a bio-egalitarian turn, which has led to a new concern for an ethics that does not assume the centrality of the anthropocentric subject. This stresses the limitations of liberal individualism as a point of reference for the discussion of practices and discourses about life or Zoe. An emphasis on the unitary subject of possessive individualism is of hindrance, rather than assistance, in addressing the complexities of our posthuman condition. In this respect, I feel quite strongly that mainstream moral philosophy and conservative neo-liberalism should be targeted for two major fallacies: their deep-seated anthropocentrism and pretentious universalism. As I argued above, the anthropocentrism and universalism of the humanist Eurocentric subject is deflated in the light of race, postcolonial and feminist critiques of its partiality, self-serving sense of entitlement and historical decline. Here, the posthumanism of social and cultural theorists working within the West in a critical perspective can be set alongside the many contemporary forms of non-Western neo-humanism. In other words, post-anthropocentric or zoe-centred posthumanism on the one hand, and anti-western neo-humanism on the other can engage in productive axes of dialogue. The point of this alliance is not to flatten out all differences of location, but rather to align them along the same axis, so as to facilitate the impact of their respective political and affective forces.

In my terms, posthuman theory is the expression of anti-individualistic nomadic politics. As such it is a critique of the centre from the centre. Here I can refer back to the earlier mentioned multiplicity of centres in a world of scattered hegemonies (Kaplan and Grewal 1994). To this end, the reference or the return to a universal is neither inevitable nor necessary. On the contrary, posthuman thought argues for a more specific and grounded sense of singular subjectivities that are collectively bound and outward oriented. If it is indeed the case that 'we 
are in this together', 'we' need a redefinition of the subject position. More specifically, we need to revisit the notion of 'pan-humanity' from within a nonunitary and non-anthropomorphic understanding of the subject. This is what I call an embodied and embedded subject (Braidotti 2006). Such a subject is always transversally related to its multiple others.

An important reason for needing a new grounded, embodied and embedded vision of the subject as a transversal and relational entity, has to do with the second half of that crucial sentence: 'we' are in this together. What this refers to is a cluster of interconnected problems that touches the structure of subjectivity and the very possibility of the future as a sustainable option. By realising that 'we' are in this together, we get the sense of a collectively bound subject that is intimately connected to non-human agents, from our genetic neighbours the animals, to the earth and the biosphere as a whole. 'We', therefore, is not an anthropocentric construct, but an eco-philosophical marker of belonging to a commonly shared territory or habitat. In other words, 'we' are part of this immanent world of ours.

How to do justice to this relatively simple yet highly problematic reality requires a shift of ethical perspective. As Haraway suggests, we need to work towards "a new techno-scientific democracy" with new norms of ethical interaction based on bio-centred egalitarianism and not on species hierarchy (1997, 95). Because of the kind of complexities 'we' are facing, we need to review methodologies in social and cultural theory that have tended to underplay the role of biological or genetic factors. This calls for a new set of alliances of a more transversal and trans-disciplinary nature, with different communities of scholars, thinkers and activists. I propose the idea of 'social sustainability' as the rallying point for the arts, contemporary culture and science to strike a new alliance (Braidotti 2006).

In my view then, 'becoming-world' is related to social sustainability. What social sustainability stands for is a grounding of the subject in a materially embedded sense of responsibility and ethical accountability for the technologically mediated environments s/he inhabits. It is a concept that helps us rethink the very possibility of the future as both duration or continuity and extinction or discontinuity. Posthuman ethics rests on the sustainable shifts or changes undergone by nomadic subjects in their active resistance against being subsumed in the commodification of their own biodiversity. Their time frame is always the future anterior, that is to say a linkage across present and past, in the act of constructing and actualising possible futures. 


\section{Conclusion}

In this chapter I have provided some theoretical parameters to define the posthuman predicament. Building on the anti-humanist legacy of the poststructuralist generation, I have examined the post-anthropocentric turn in social and cultural theory. I have argued that the changing relationship to biogenetic sciences and technologically mediated culture lies at the core of the posthuman condition. This forces upon us the need to reconsider some leading concepts of subjectivity and self-other relations, in ways that respect the complexity of our scientific knowledge of the basic unit of the 'human'. In the second half of the chapter I have focussed on the ethical implications of these shifts in our understanding of the subject as a relational entity, embodied and embedded in the world, and related to multiple others.

As a conclusion, I would enlist, rather than dismiss, the contribution that philosophical theories of the posthuman can make to the debates on contemporary science, epistemology and the ethics of scientific research. Philosophical investigations of post-anthropocentric subjectivity offer alternative ways of accounting for the embedded and embodied nature of the subject. They are indeed relevant and generous allies in the ongoing efforts to develop an approach to subjectivity worthy of the complexities of our age. One needs at least some subject position, but it need not be either unitary or exclusively anthropocentric. Rather it must be the embodied and embedded site for the political and ethical accountability that we need to understand and sustain a fastchanging, technologically mediated world.

\section{Bibliography}

Ansell Pearson, K. 1997. Viroid Life. Perspectives on Nietzsche and the Transhuman Condition. London and New York: Routledge.

Braidotti, R. 1994. Nomadic Subjects. Embodiment and Sexual Difference in Contemporary Feminist Theory. New York: Columbia University Press.

Braidotti, R. 2002. Metamorphoses. Towards a Materialist Theory of Becoming. Cambridge: Polity Press.

Braidotti, R. 2006. Transpositions. On Nomadic Ethics. Cambridge: Polity Press.

Deleuze, G. and F. Guattari. 1972. L'anti-Oedipe. Capitalisme et schizophrénie I. Paris: Minuit.

Deleuze, G. and F. Guattari. 1980. Mille plateaux. Capitalisme et schizophrénie II. Paris: Minuit.

Foucault, M. 1966. Les mots et les choses. Paris: Gallimard.

Foucault, M. 1975. Surveiller et punir. Paris: Gallimard.

Fox-Keller, E. 1995. Reflections on Gender and Science. New Haven: Yale University Press. 
Franklin, S. 2007. Dolly Mixtures: The Remaking of Genealogy. Durham: Duke University Press.

Gilroy, P. 2000. Against Race. Imaging Political Culture Beyond the Colour Line. Cambridge, MA: Harvard University Press.

Grewal, I. and C. Kaplan, eds. 1994. Scattered Hegemonies: Postmodernity and Transnational Feminist Practices. Minneapolis: University of Minnesota Press.

Griffin, G. and R. Braidotti. 2002. Thinking Differently. A Reader in European Women's Studies. London: Zed Books.

Guattari, F. 1992. Chaosmose. Paris: Galilée.

Guattari, F. 2000. The Three Ecologies. London: The Athlone Press.

Habermas, J. 2003. The Future of Human Nature. Cambridge: Polity Press.

Halberstam, J. and I. Livingston, eds. 1995. Posthuman Bodies. Bloomington: Indiana University Press.

Hayles, K. 1999. How We Became Posthuman. Virtual Bodies in Cybernetics, Literature and Informatics. Chicago: The University of Chicago Press

Haraway, D. 1997. Modest_Witness@Second_Millennium.FemaleMan@_Meets_Oncomouse $^{\mathrm{TM}}$. London, New York: Routledge.

Haraway, D. 2003. The Companion Species Manifesto. Dogs, People and Significant Otherness. Chicago: Prickly Paradigm Press.

Harding, S. 1986. The Science Question in Feminism. London: Open University.

Hardt, M. and A. Negri. 2000. Empire. Cambridge, MA: Harvard University Press.

Hill Collins, P. 1991. Black Feminist Thought. Knowledge, Consciousness and the politics of Enpowerment. New York and London: Routledge.

Irigaray, L. 1974. Spéculum. De l'autre femme. Paris: Minuit.

Kaplan, C. and Grewal, I. 1994. Scattered Hegemonies. Minneapolis: University of Minnesota Press.

Lacan, J. 1998. The Seminar of Jacques Lacan, Book XX: Encore, On Feminine Sexuality, The Limits of Love and Knowledge 1972 - 1973, trans. B. Fink. New York: W.W. Norton

Latour, B. 2005. Reassembling the Social: An Introduction to Actor-Network-Theory. Oxford: Oxford University Press.

Lloyd, G. 1985. The Man of Reason. London: Methuen.

Margulis L. and Sagan Dorion. 1995. What is Life? Berkeley: Berkeley University Press.

Massumi, B. 1998. Requiem for our Prospective Dead! (Toward a Participatory Critique of Capitalist Power). In Deleuze and Guattari. New Mappings in Politics, Philosophy and Culture, eds. E. Kaufman and K.J. Heller. Minneapolis: University of Minnesota Press.

Massumi, B. 2002. Parables for the Virtual. Movement, Affect, Sensation. Durhman: Duke University Press.

Maturana, H. and F. Varela. 1972. Autopoesis and Cognition. The Realization of the Living. Dordrecht: Reidel Publishing Company.

Parisi, L. 2004. Abstract Sex. Philosophy, Bio-Technology, and the Mutation of Desire. London: Continuum Press.

Rose, N. 2001. The Politics of Life Itself. Theory, Culture \& Society. 18(6): 1-30.

Said, E. 1978. Orientalism. London: Penguin Books.

Shiva, V. 1997. Biopiracy. The Plunder of Nature and Knowledge. Boston: South End Press.

Spivak, G. C. 1999. A Critique of Postcolonial Reason. Toward a History of the Vanishing Present. Cambridge, MA: Harvard University Press. 
Spivak, G. C. 2003. Death of a Discipline. New York: Columbia University Press.

Stacey, J. 2000. The Global Within. Consuming Nature, Embodying Health. In Global Nature, Global Culture, eds. S. Franklin, C. Lury and J. Stacey. London: Sage.

Ware, V. 1992. Beyond the Pale. White Women, Racism and History. London and New York: Verso.

Wittig, M. 1992. The Straight Mind. New York and London: Harvester Wheatsheaf. 


\section{Part II: Media}


Open-Access-Publikation im Sinne der CC-Lizenz BY-NC-ND 4.0 (C) 2010, V\&R unipress GmbH, Göttingen 


\section{Chapter 5: Cinematic Fantasies of Becoming-Cyborg}

\section{Introduction}

In the last few years several TV-commercials have featured an appealing image of a man-machine. In 2005, a one minute commercial was edited in such a way that a young boy becomes a man while he is running through a modern city jumping from heights, crossing huge gaps, climbing buildings, and hanging from cables. At the end he changes into a car, a Renault Clio 3 . The suggestion is that the natural growth and evolution of a male subject culminates in a man-machine. The same year another one minute commercial of the man-car theme was issued, but this time the other way around: Citroën $\mathrm{C} 4$ showed a car becoming man. Citroën C4 commercials started in 2005 and continue the theme until now, with the car-man-machine skating on ice, dancing in the streets, or doing a warming up for fitness. The huge robot consisting of car parts is quite endearing in its human-ness. Those commercials are just one example of the popularity of the man-machine in contemporary visual culture, which can be found in commercials, music videos, fashion photography, television series, cinema, computer games and web 2.0 applications like Second Life.

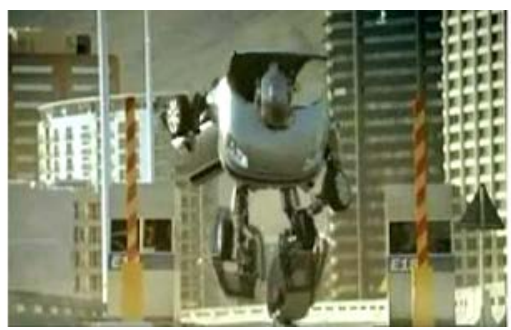

Figure 5.1: Car becoming man; image grab from Citroën C4 TV-commercial 2005.

The man-machine is clearly one of the prevailing figurations in a culture dominated by science and technology. Almost from its beginning cinema has seen science and technology as potentially threatening, for example in the figure 
of the mad scientist producing an evil cyborg, like Rotwang creating the robot Maria in Metropolis (1927) (see also Merzagora's essay in this volume). In the popular imagination, machines were enslavers rather than liberators, for instance the human masses enslaved by the colossal machines in Metropolis, or, more comically, Charlie Chaplin caught in the wheels and cogs of a giant machine in Modern Times (1936). The car commercials that I introduced above show that a major shift has occurred in the popular imagination: visual culture of today is not scared by science and technology but embraces it full-heartedly. The machine no longer enslaves man but happily fuses with man - or with woman, like in Björks innovative music video 'All is Full of Love' (1998).

\section{The Posthuman Cyborg}

I take the man-machine in its contemporary manifestation as a cyborg, a cybernetic organism, which indicates a feedback system between man and machine and is thus an updated version of earlier figurations such as the robot or android. The term was introduced by Donna Haraway as a utopian concept for posthuman identity in her famous 'Cyborg Manifesto' (1991). In popular culture, the figure of the cyborg projects a fantasy of the human who fuses with technology and becomes a superior being in the process. Especially the genre of science fiction, both literary and cinematic, explores the cyborg as a hybrid of human, science and technology in a posthuman world (Sobchack 1997). As scientific developments in genetics, information technology and cybernetics open up new possibilities of intervention in human lives, cultural theorists have explored the notion of the 'posthuman' (Zylinska 2002; Bell \& Kennedy 2000). The term posthuman indicates a historical period in which the technological factor is primary over a naturalistic assumption about the human subject. The notion thus helps to overcome the nature/culture distinction (Haraway 1991; Hayles 1999; see also Rosi Braidotti's essay in this volume). The posthuman cyborg points to deep-seated desires of fusing man with science and technologies as well as to equally deep-rooted anxieties about the dominance of science and technology over the fragile human body and mind. Popular images of the cyborg often reinforce the mind/body split in western culture, raising questions about artificial intelligence, mediated memory and fractured identity (Gray 1995). Those figures also have different, and often complex, relations to gender.

In this essay I will explore images of the human-machine cyborg in contemporary visual culture, mostly in science fiction movies, a genre with both its utopian and dystopian aspects. The cyborg is one of the ways in which popular culture has answered to the 'call' of science and technology. It is a figure probing 
what it means to be a human being in a time when science and technology can heal and enhance or on the contrary hurt and destroy the human species. The blurring of boundaries between human/machine, nature/culture, technology/ organism, sex/gender, heralded by the figuration of the cyborg, has proved to be a fruitful framework for studies of the posthuman and constitutes a point of departure for this essay. At the same time, I will use methods of analysis from film studies to investigate the particularly visual aspects of the cyborg figuration. I will finish the essay by pointing to cultural practices in contemporary society that are inspired by the figure of the cyborg.

\section{The Genre of Cyborg Movies}

The cyborg film is a hybrid genre with its roots in science fiction, horror and action movies (Roberts 2000; Perkowitz 2007). Some consider it therefore to be a postmodern genre (Kuhn 1990; 1999). The cyborg certainly is a postmodern configuration in its hybridity between human flesh and metal or digital material, its wavering between mind and matter, and its volatility between masculinity and femininity (Bukatman 1993; Dery 1996). The cyborg is thus a typical postmodern figuration of the 'in-between'.

Digital technology has recently provoked some significant transformations in the image of the cyborg, moving away from the hardware cyborg of the 1980s to the software and wetware cyborgs of the 1990s. This is not a neat evolution because the hardware cyborg still dominates the popular imaginary, as we have seen in the car commercials. The hardware cyborg combines a human body with technology in the form of implantations or prostheses: for example, the metallic figures of the Terminator (Arnold Schwarzenegger) and RoboCop (Peter Weller). In contrast, the software cyborg is a human who can hook up to a computer. For example, Johnny Mnemonic (Keanu Reeves) in the eponymous film can upload data into his brain by plugging in, while the mercurial T-1000 (Robert Patrick) in Terminator 2 (1991) can take on any form whatsoever because he consists of a computer programme and thus his substance is malleable. Finally, the wetware cyborg is a mixture of digital technology and a 'wet' humanoid inside, like Cash (Wynona Ryder) in Alien Resurrection (1997). The wetware cyborg often acquires generic traits of the horror genre, as the body can splatter into bloody or slimy fragmentation. I will first discuss the ways in which cinema shows that the cyborg is both human and machine at the same time, before going into issues of identity, memory and gender that are prominent in science fiction movies. 


\section{Point of View}

While commercials show us smooth transitions from man to car or vice versa, a Sci-Fi movie has to convince the spectator that the human figure she sees on the screen is in fact a cyborg. Apart from obvious narrative clues in dialogue and plot, cinema uses two visual strategies to make this clear to the audience: the subjective camera shot and the reparation scene. The cyborg is often introduced with a subjective point-of-view (POV) or over-the-shoulder shot. Bordwell and Thompson describe the POV-shot as "A shot taken with the camera placed approximately where the character's eyes would be, showing what that character would see; usually cut in before or after a shot of the character looking" (2008, 480 ). In the case of the cyborg, such a subjective POV-shot contains computerised elements within the frame, representing the cyborg's eye like a video camera that can zoom in and out, process data, check a target, and rewind or repeat the image. For example, when the Terminator (Arnold Schwarzenegger) lands nude on Earth from outer space in Terminator 2 (1991), he surveys his new surroundings with a piercing gaze. The film shows what he sees in a red, digitalised image through a sustained POV-shot. In RoboCop (1987) there are several scenes of long POV-shots in which the camera films as if it were the eye of RoboCop (Peter Weller) while it is being fabricated in the laboratory, giving the idea of a robot being imprisoned in a human body. In Eve of Destruction (1990) a female cyborg, Eve 8 (Renée Soutendijk), checks out the men in a café through a POV-shot with red lights and bleeping sounds, before beating them up when they harass her.

The function of the POV-shot in the Sci-Fi movies is clear: it has to prove to the spectator that the character is not a mere human being but a cyborg. The computerised elements within the frame emphasise the machine-like aspect of the cyborg, as its eye functions like a camera with superior vision enhanced by technology. Being embodied by a live actor or actress, the cyborgs at first sight look like 'normal' humans. Significantly, after having been introduced by the POV-shot to the spectator as a cyborg, the other characters in the film still have to be convinced. The cyborg therefore usually proceeds to fight in the next scene and show its crushing strength over humans.

While the POV-shot with its technological cues within the frame thus ascertains the 'cyborg-ness' of the character, typical techniques of the POV shot, such as mobile framing, close-ups and camera movement, are at the same time powerful cinematic cues for subjectivity. In film studies the impact of a POV-shot is taken to produce character subjectivity. Thus, another effect of the POV-shots is to simultaneously ascertain the subjectivity of the cyborg, which makes it partly - human. This allows for empathy and perhaps even identification of the audience with the 'human-ness' of the cyborg. 


\section{Reparation of Wounds}

Another visual topos in cyborg films is to systematically destroy the cyborg so as to repair it. Superhuman invincibility may be one characteristic of the cyborg proving the superiority of technology over the human body, but the cyborg is surprisingly vulnerable to assault and injury. After the cyborg is reduced to just a heap of shrapnel, it can be put together again either by itself or in the lab.

Such reparation scenes excel in ambiguity, because the once-unbeatable machine has become defenceless flesh. To give a few examples: in The Terminator (1984) the cyborg repairs his wounded eye in a typical horror scene that shows the wet inside of the body. When he takes out his eye and drops it in the washbasin, the socket not only shows a bloody wound, but also a camera that still functions by zooming in and out. In RoboCop, the cyborg drills into his head with a machine, taking off the metal prosthesis that reveals his human flesh. In Eve of Destruction Eve 8 undresses and exposes a gaping wound in her chest, which she enters with her own hand apparently restoring it and then gluing it over with red tape. While the scenes disclose wounded flesh, making the spectator shudder in her seat with horror, they show once again the superiority of the cyborg who can penetrate and repair its own body and continue as if nothing happened. Reparation scenes are thus a cinematic way of visualising the hybrid character of the cyborg.

Interestingly, the reparation scenes typically involve mirrors: the Terminator, RoBoCop and Eve 8 look into a mirror while they are tending their wounds. The mirror is a well-known visual theme in cinema where it functions as a moment of self-reflection for the character. In film studies, Mulvey (1975) and Metz (1977) have connected the look into the mirror to the psychoanalytic concept of ego formation in the mirror stage conceptualised by Lacan. Mulvey and Metz argue that the way in which the child derives pleasure from the identification with a perfect mirror image and forms its ego ideal on the basis of this idealised image, is analogous to the way in which the film spectator derives narcissistic pleasure from identifying with the perfected image of the hero on the screen. In the case of a literal mirror in visual culture, whether in paintings, cinema, music videos or fashion photography, there is then a double 'look': the primary one of the character looking into the mirror, and the secondary one of the spectator identifying with the character, mediated by the camera (or painter).

Self-reflection presupposes a degree of subjective consciousness. Thus, by putting the cyborg in front of a mirror, the films suggest that the cyborg is actually thinking about itself. A clear example is RoboCop, where the cyborg becomes emotional as he checks out the mirror for signs of his former, human, self. Landsberg (2004) has shown that the cyborg is often surrounded not only by mirrors but by reflective surfaces like a video monitor or computer screen. She 
argues that the mirroring surface allows for a moment of uncanny self-recognition and even self-reflection, in scenes that are reminiscent of the Lacanian mirror phase. On the one hand, the cyborg characters see a perfected image of the human figure reflected in the mirror, because as man/machines they are literally enhanced and thus perfected human beings. On the other hand, they see a distorted image in the mirror because they are wounded and disfigured. Quite significantly, the mirror scenes suggest that the cyborgs are quite confused about their hybrid identity: Who are they? Man or machine? Why do they experience pain or feelings? Do they have memories?

\section{Identity and Memory}

Now that I have explained two cinematic ways of ascertaining the character as a cyborg in Sci-Fi movies, the POV-shot and the wounding/repairing scene, it is actually surprising to find out that the cyborg is rather uncertain about its own status. In fact, the postmodern cyborg finds itself in quite the same predicament as 'real' people. Perhaps we could say that its postmodern hybridity, its inbetweenness, produces an identity crisis: is it a mere machine, or is it also a man, or both? The crossing and blurring of binary oppositions creates confusion. Sometimes such confusion leads to some comic relief: when Douglas Quaid (Arnold Schwarzenegger) in Total Recall (1990) finds out that he is not Mr. Quaid, but that his memory is implanted and that his whole life, including his marriage and his own wife, is fake, he calls out in desperation: "But if I am not me, who the bloody hell am I?" In a sadder example from the cult classic Blade Runner (1982) the cyborg Rachel (Joanna Cassidy) bursts into tears when she finds out she is a 'replica' (the term for the cyborgs in this film), because she was really convinced that she was a human being with her own personal memories and feelings. The ambivalent point here is that she cries while replicas are not supposed to have emotions.

Whether comic or tragic, the identity crisis is a stock theme in the science fiction films of the last twenty years of the previous century. The hybrid figures are confused about their own status, not unlike the Taoist question 'Am I a human dreaming that I am a butterfly, or am I a butterfly dreaming that I am human?' Moreover, the identity crisis is often not brought to closure, which is a rare ending for Hollywood cinema. Blade Runner suggests at the very end that Deckard, the main character, is actually a replica; and when Quaid has created a new earth and a new heaven on Mars in Total Recall his last words are: "And what if I have dreamt it all?" The films thus refuse to anchor human identity in the cyborg, maintaining its hybridity until the very end.

Early cyborg movies, such as Blade Runner, RoboCop, Total Recall and the 
Terminator-films (Penley 1991), tell stories about the crisis of identity often induced or increased by prosthetic memory. The identity crisis is mostly focused around issues of memory, because personal memories function as an index for subjectivity. Prosthetic memory is thus typical of the cyborg movies of the 1980s and 1990s, where implantations complicate the relation between memory, experience and identity (Landsberg, 2004). The visual clues for subjective memories are photographs, which are supposed to 'prove' the personal past of the cyborgs. But where photos usually function as documents of truth, in cyborg films they acquire an ambiguous and much darker status as they are wilful manipulations of the past and suggest that personal memories have been implanted. Such films focus on anxieties aroused by the paradoxical experience of remembering events that the character has not lived through (Radstone 2000). Silverman (1991) has argued that photography is thus used to expose the fragility of postmodern identity.

There is a significant shift in the treatment of the identity crisis in contemporary science fiction cinema, because the - now digital - technologies of memory shift to other grounds, away from implanted or prosthetic memory. In Sci-Fi films of the twenty-first century, the story centres more on the relation between the superior memory of the computer and the failing memory of the human being. Hence, the issues transfer from a superior body to manipulations of the mind. ${ }^{1}$ Digital media have created new ways of saving, retrieving, and archiving personal and collective memories (Van Dijck 2007). Science fiction writer William Gibson has claimed that for him, computers are no more than a metaphor for human memory (Cavallaro 2000). In contemporary science fiction, the fantasy has undoubtedly become one of control. Therefore, with digital technology the concern is no longer with the implantation of false memories, since the characters remember lived experiences. Rather, the utopian fantasy now centres on total recall that is enabled by the continuous enhancement of computer memory, while the dystopian fantasy focuses on the deletion and distortion of digitalised memories.

I will give the example here of one of the first films in its genre, Johnny Mnemonic (1995), based on a few short stories by cyberpunk writer Gibson. ${ }^{2}$

1 There are two other new themes in contemporary Sci-Fi movies: simulated reality as in The Matrix trilogy and genetic manipulations; for reasons of space I cannot pay attention to these kinds of films.

2 More examples of recent Sci-Fi films on digital technology as registering or deleting individual memories, are: Minority Report (2002), Final Cut (2004), The Butterfly Effect (2004 and its sequel in 2006), and the manga film The Ghost in the Shell (1995). Films on memory that skirt the borders of the science fiction genre include The Bourne Trilogy (2002, 2004, 2007), Eternal Sunshine of the Spotless Mind (2004) and the Chinese film 2046 (2004). An interesting mix of time travel and memory confusion can be found in the British television series Life on Mars (2006-2007) and its sequel Ashes To Ashes (2008-2009). 
The hero uploads certified data into his brain in order to bring them to people on the other side of the world. To make space for the data, Johnny (Keanu Reeves) has to temporarily download (and thus be deprived of) his personal memories of his deceased mother (as in Blade Runner the mother functions as the oedipal sign of human identity and memory; see Silverman 1991). If he is unable to download the computer data within 24 hours, he will die of 'information overload'. Only when he can discharge the data, is he able to reload the personal memories. Of course, Johnny is saved just in time to retrieve his early memories of his mother.

Contemporary Sci-Fi movies convey the futuristic fantasy that private memory can be captive of technology in such a way that it becomes transparent and visible, for example by projecting it as images on a screen. ${ }^{3}$ Identity gets fully shot through with technology, as individual memory can digitally be retrieved, represented, remediated, transformed or deleted. The films suggest that private memory is a prison that keeps the subject chained to the past and that technology can offer the character liberation from his or her memories, and thus from the past, opening up new vistas for the future. This Sci-Fi fantasy responds to cultural anxieties around digital technologies as pervading contemporary culture and transforming our relation to personal and archival memory.

\section{Women: Strong \& Sexy}

As feminist studies have shown, an important aspect of human identity is gender; the social and cultural role, construction and performance of one's biological sex. The question here is: do cyborgs have a sex or a gender? In her 'Cyborg Manifesto' Haraway (1991) introduced the cyborg as a new and enabling figuration for women. The manifesto's principle message to women was to take responsibility for the social relations of science and technology. The cyborg was attractive to Haraway, because it blows up dualities by melding the borders between the human and animal, between the organic and the mechanical/machine, and between the physical and the non-physical. The cyborg could figure as a fresh image for a hybridised, fragmented, postmodern, subjectivity.

As we have seen above, the cyborg is indeed a postmodern figure of the inbetween', who is in a quandary about its own hybrid identity. Does this also mean that the Hollywood cyborg represents a hybridized, flexible, postmodern

3 Elsewhere, I have shown how the technological digitalisation of memory and identity in contemporary science fiction films results in two different trajectories: on the one hand the spectacular visualisation of memories; and on the other hand a fragmented narrative in which past, present and future become confused (Smelik 2009). 
subjectivity of men and women? Hardly so, I am afraid; in fact, gender stereotypes are much repeated in the imagery of the cyborg. Firstly, there are many more male than female cyborgs; secondly, male cyborgs are characterised by their hard, strong and infallible body; and thirdly, the (few) female cyborgs are highly sexualised. To give a recent example: in 2008 the multinational Philips launched a campaign for a new shaver for men, Robotskin. In the one minute commercial a female, Asian looking cyborg, helps a nude man to shave under the shower. She is shy, subservient and attractive. The end of the commercial suggests that the man and the cyborg will have sex. The lighting is blue, the pace slow and languid, and the music is a mix of ambient techno that sounds vaguely Asian. While it is probably inspired by the popular videoclip 'All is Full of Love' (1998), the commercial could not be further removed from Björks radical message of (lesbian) love between human and machine. The erotic tone and setting of the Robotskin commercial could also not be more different from the two car commercials that I introduced at the beginning, which gave us the figure of an exclusively macho fusion between man and car/machine.

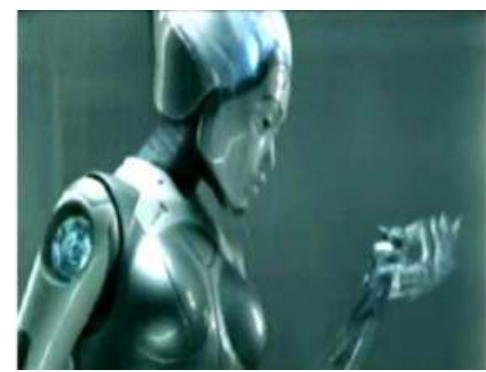

Figure 5.2: Eroticised female cyborg; image grab from Philips Robotskin TV-commercial 2008.

While there are few female cyborgs in the genre, it is interesting to note how often they are explicitly linked to female sexuality (Balsamo 1996). One of the most sexist examples is the film Cyborg II (1993) that opens with a scene of male scientists watching their new weapon in action: a female cyborg who seduces the enemy into sex and explodes at the moment of her orgasm. Another dire stereotype is the sex cyborg played by Melanie Griffith in Cherry 2000 (1987), a predecessor of Robotskin's female cyborg in the Philips commercial. The earlier mentioned cyborg Eve 8 in Eve of Destruction (1991) is a more complex image of a sexualised cyborg. Sexy in her red leather jacket, she is quite literally a castrating monster who bites off the penis of a man that tries to rape her and killing any man that bothers her. In a striking visual scene, the film exposes the physical position of her lethal weapon. After a car accident, the camera enters the cyborg's body through the mouth (in an anatomically incorrect camera move- 
ment), ending up in her womb where a nuclear bomb gets activated. Again, the female reproductive organs are represented as the site for lethal explosions.

Many Sci-Fi movies have intricate representations of the inside of the cyborg body or of cyberspace as a tunnel, a surging vortex of turning and twisting imagery. Elsewhere, I have explored this kind of tunnel imagery in both cyberpunk movies and medical documentaries (Smelik 2008); here it suffices to draw attention to the double meaning of the matrix as a metaphor that is frequently used for cyberspace while its literal denotation derived from Latin is 'womb' or 'breeding female'. By situating the nuclear bomb or the lethal weapon in the matrix, films like Cyborg II and Eve of Destruction repeat the cultural fears of the - literally - explosive powers of female reproduction and sexuality (Springer 1996; see Ferreira's essay in this volume for feminist reworkings of the matrix in bio-art).

The shift from the hardware to the software cyborg in the 1990s allowed not only for a different image of masculinity, as I will argue below, but also opened up to a greater diversity of female cyborgs, like Ripley 8 (Sigourney Weaver) as a woman of steel or the humane cyborg Cash (Wynona Ryder) in Alien Resurrection (1997). A.I. (Artificial Intelligence, 2001) is peopled with male and female cyborgs who look quite similarly plastic in their present form, and who become completely gender-less in their futuristic forms. In films like Gattaca (1997), Existenz (1999) or The Matrix trilogy (1999-2003) the actors and actresses are made up to look alike in their androgynous appearance.

I want to argue that the image of the female cyborg of today has retained the erotic appeal of female beauty, but without the concomitant fears and anxieties concerning female sexuality or reproduction. In contemporary cyber culture, computer games have taken over much of the gendered imagery from Sci-Fi movies. In the Tomb Raider films, for example, Lara Croft (Angelina Jolie) is stunningly beautiful, but also invincibly strong. Although Lara Croft is technically speaking not a cyborg, she is unrealistically strong as a man/machine and can conquer every man and every machine in her personal quest for justice (Kennedy 2002). Her fitness and her phallic weapons make her an insuperable warrior. It is noteworthy that as erotic object, she is not available for the male characters in the film (Mikula 2004). She is even markedly independent and does not maintain any sexual relations. The combination of beauty, strength and independence has been the characteristic of film heroines and cyborgs since the 1990s (Tasker 1993; Walden 2004). Lara Croft is thus exemplary of the ambivalent woman's image in recent Sci-Fi movies: eroticised as a woman and masculinised as a cyborg. 


\section{Gender (m): Virile Looks}

The hardware cyborgs of the 1980s like the Terminator and RoboCop were, of course, exaggeratedly masculine: hard, made of steel, and muscled. In short, they were phallic in a way that Tarzan could only approximate. Feminist critics have suggested that the hyper-masculinity of the cyborg points precisely to the fear and anxiety of the loss of manhood and thus reflects the anxieties of white men (Tasker 1993; Holland 1995). Jeffords (1994) described the development in American cinema of the 1990s where the white hero combines the superman icon with the image of the 'New Man', whose major role is to be the father and protector of his family. RoboCop, for example, is haunted by memories of his wife and child and quite overwhelmed by feelings when he finds out who he was before he became a cyborg. This leads to the comical complaint of the technicians in the lab that "the robot has emotional problems". Even the cyborg played by Schwarzenegger in Terminator II is seen by the main female character Sarah (Linda Hamilton) as an ideal father for her child who is more perfect than any male companion could be. The cyborg, then, becomes the unexpected image of the new family man ${ }^{4}$.

The steel armour of masculinity also showed other signs of wear and rust. From the 1980s onwards there has been a distinct change in the visual representation of men in popular culture, in that the body became the object of the voyeuristic gaze. The male body has gradually become fetishised in visual culture in much the same way as women traditionally were in Hollywood cinema. While most critics have commented on the changing image of men in commercials or music videos (Simpson 1993; Hall 1997), I maintain that the same trend happened in the cyborg movie. The voyeuristic gaze does not only pertain to male models or singers, but also to the hyper-masculine cyborg whose body gets fragmented, objectified and eroticised.

Take for example the following scene from Universal Soldier (1992), in which a cyborg and a woman are fleeing from the enemy. She has to look for a computer chip in his body so that they cannot be traced. The cyborg, played by Jean-Claude van Damme, strips naked and asks her to check his body for "something hard". She is quite embarrassed and comments on his good physique, while the camera languishes on his impressive torso, glides across his biceps, revels in his hard nipples and zooms in on his leg. Looking down he asks her whether "that hard thing" belongs there and she coyly tells him that it is rather normal. Then she finds the chip in his leg, cuts it out, and faints at the gush of blood. The joke on the hard and erect penis recalls a scene in one of the few cyborg films made by a

4 This took a rather funny twist with Schwarzenegger as a nanny in Kindergarten Cop (1990) and a decidedly absurd turn with him as a pregnant woman in Junior (1994). 
woman (Susan Seidelman), Making Mr. Right (1987), where the cyborg (John Malkovich) asks what his big penis is for. The scientists who constructed him answer not to worry because it is there to give him confidence.

Such - admittedly feeble - jokes point to the fragility of the cyborg's manhood that is simultaneously celebrated by the camera, eroticised for the spectator's gaze, and undermined by the narrative. As a rather physical genre of battle and action, Sci-Fi movies illustrate how the male body is equally the object of relentless visualization as the female body. Odd narrative motivations help to display the masculine, constructed, body-built, body in al its naked triumph, for example the Terminator landing nude on Earth from outer space in Terminator 2 (1991), or the terrorist attack on Bruce Willis who happens to be in the bathroom, causing him to fight in his underpants throughout the first Die Hard movie (1988). While the trend was ambivalent at first, because it puts the male character in the position of the spectacle, a structurally feminine position, in the course of the last two decades the audience has grown more familiar with the scopophilic gaze at the male body as 'to-be-looked-at-ness' (Mulvey 1989), especially in the videoclips from music television. ${ }^{5}$ Moreover, the development of the objectification and eroticisation of the male body fits perfectly with the wound-and-reparation scenes that I discussed above. As many a cyborg movie shows, the male cyborg can be eroticized by the camera and tortured in the very core of his masculinity, while retaining his virility. Contemporary images of men, even of male cyborgs, combine feminine attributes of beauty and vulnerability with macho characteristics of hard muscles and invincibility. ${ }^{6}$

The image of the male cyborg, then, has undergone some transformations. The shift from the hardware to the software cyborg, and from issues of the body to the mind, also contributed to a different image of masculinity. Hardware cyborgs of the 1980s were typically played by heavy bodybuilders like Schwarzenegger, Lundgren, Van Damme or Stallone, while software cyborgs of the 1990s are performed by less macho actors, like Keanu Reeves in Johnny Mnemonic (1995) and in The Matrix trilogy (1999-2003), or Jude Law in Gattaca (1997), Existenz (1999) and A.I. (Artificial Intelligence, 2001).

Recently, visual culture seems to advance a renewed celebration of the man/ machine. We already saw the happy man/car cyborgs of the Renault and Citroën commercials. In 2008, several blockbusters were launched that show men per-

5 As Mark Simpson (1994) has argued, the eroticised look was initially taken from homosexual culture. He introduced the term 'metrosexual' to indicate that heterosexual men can no longer permit to be careless about their looks and are allowed and required to be as narcissistic as women. As Simpson argues, the metrosexual mediates his masculinity. See 'Here come the mirror men', in: The Independent, November 15, 1994: www.marksimpson.com

6 Examples of such 'metrosexuals' in popular culture abound, from Daniel Craig as James Bond in Casino Royale (2006) to the Armani ads of David Beckam. 
fectly in synch with the machines that they build for themselves, and eventually incorporate into themselves: the Sci-Fi films Iron Man and Speed Racer and the fantasy film Batman; The Dark Knight. Speed Racer even imitates the car commercials in that the main character becomes one with the T180 that he drives. The movies continue the by now well-established tradition of men fusing with their machines, and they are remarkably upbeat about that symbiosis. ${ }^{7}$ While The Dark Knight may be as dark as its title in its treatment of the morals of contemporary politics, it is certainly not dwelling in the vaults of anti-scientific dystopia. It seems to me that contemporary visual culture full-heartedly embraces the figure of the cyborg.

\section{Becoming-cyborg}

In this article I have traced reconfigurations and remediations of the human body through the figure of the cyborg in Sci-Fi movies. I want to conclude by speculating how images of the cyborg in visual culture spill over into social practices of 'real' human beings. In my view, there are at least four, overlapping and interlocking, practices that are inspired by the cyborg figuration: the military, sports, fitness and cosmetic surgery.

Firstly, cyborg imagery has recently become familiar with a global TV-audience through the gear of soldiers in the wars of Irak and Afghanistan. The western troops look uncannily like cyborgs from Sci-Fi movies or computer games. Secondly, while the bodies of soldiers are enhanced through gear and technology, sports is a terrain where the actual physiques of men and women have become enhanced beyond the standard boundaries of the human body. The recurring stories of doping suggest that the bodies of sportsmen and women are indeed artificially improved. Commercials for sportswear play into the cyborg imagery, as for example in the ad 'Puma Football Until Then' where the football players look like animals with cyborg legs that turn into Puma sneakers. This image is in turn taken from the handicapped runner Aimee Mullins, often dubbed 'cyborg', who has become famous for her prosthetic legs, both as a sportswoman and as a model and actress.

The third example of cyborg imagery leaping over into real life is related to sports: the practice of fitness. From school kids to presidents, from housewives to managers, from celebrities to princes/ses, affluent people across the globe jog, do sports, or go to the gym, to keep fit and slim. A fit, strong and muscled body, then, is no longer the prerogative of a bodybuilder who plays a cyborg. Especially in visual culture, the body shape of actors and actresses, singers and performers,

7 See Richard Corliss' review of Iron Speed and Speed Racer in Time, May 19, 2008: 57-58. 
has changed considerable in the last few decades. Bodies have become much more fit and muscled over the last few decades, as can be easily traced through the range of actors that played James Bond or the Batman from the 1960s till now. The positive image of the cyborg $(\mathrm{m} / \mathrm{f})$ as strong and sexy is in keeping with popular culture of today celebrating fitness and sexiness. The new standard of beauty fits in with the fourth cultural practice that makes contemporary men and women more posthuman: cosmetic surgery. No longer an exclusive privilege for the rich and famous, cosmetic surgery is by now established as a huge industry to keep up an image of fitness, beauty and youth for men and women alike. TV-shows like Extreme Makeover play into the desire of people to alter and transform their face and body and eradicate any signs of wear and tear (Sobchack 2004).

What links these four social practices together, is the contemporary belief that the human body can be controlled, altered and perfected. In that belief, and in the process of incorporating technologies of warfare, sports, fitness or cosmetic surgery, humans are becoming cyborgs.

\section{Conclusion}

Having explored the cyborg in Sci-Fi movies and having traced some cultural practices of enhancing and altering the human body, I conclude that the cyborg is no longer a figure that instils fear or anxiety. Rather, the figure of the cyborg points to deep-seated desires of the post-human to fuse with science and technologies. This is not only apparent in the popularity of the cyborg in visual culture, but also in the practices of everyday life. Human beings of the twentyfirst century take control of their own destinies by entering intimate relationships with the machines that they build and construct. Thus, they are posthuman in the sense that the body is no longer a category of nature that can be kept separated from culture, i. e. from science and technology. The social and cultural practices of the military, sports, fitness and cosmetic surgery show the extent to which the scientific imaginary has penetrated the self-fashioning of human beings as cyborgs, male and female alike. The shiny couture of the cyborg becomes us all too well.

\section{Bibliography}

Balsamo, A. 1996. Technologies of the Gendered Body. Reading Cyborg Women. Durham and London: Duke University Press.

Bell D., and B. Kennedy, eds. 2000. The Cybercultures Reader. London: Routledge. 
Bordwell, D., and K. Thompson. 2008. Film Art. An Introduction. New York: McGraw Hill. Bukatman, S. 1993. Terminal Identity: The Virtual Subject in Postmodern Science Fiction. Durham: Duke University Press.

Cavallaro, D. 2000. Cyberpunk and Cyberculture. Science Fiction and the Work of William Gibson. London: Athlone Press.

Dery, M. 1996. Escape Velocity. Cyberculture at the End of the Century. New York: Grove Press.

Dijck, J van. 2007. Mediated Memories in the Digital Age. Stanford: Stanford University Press.

Gray, C.H., ed. 1995. The Cyborg Handbook. London: Routledge.

Hall, S. 1997. Representation. London: Sage.

Haraway, D. 1991 [1985]. A Manifesto for Cyborgs: Science, Technology, and Socialist Feminism in the 1980s. Reprinted in Simians, Cyborgs, and Women: The Reinvention of Nature, D. Haraway, 149-81. London: Free Association Books.

Hayles, K. 1999 How We Became Posthuman. Virtual Bodies in Cybernetics, Literature, and Informatics. Chicago and London: The University of Chicago Press.

Holland, S. 1995. Descartes Goes to Hollywood: Mind, Body and Gender in Contemporary Cyborg Cinema. Body and Society 1(3-4): 157-74.

Jeffords, S. 1994. Hard Bodies. Hollywood Masculinity in the Reagan Era. New Brunswick. Rutgers University Press.

Kennedy, H. W. 2002. Lara Croft: Feminist Icon or Cyberbimbo? On the Limits of Textual Analysis. The International Journal of Computer Game Research II(2).

Kuhn, A., ed. 1990. Alien Zone: Cultural Theory and Contemporary Science Fiction Cinema. London: Verso.

Kuhn, A., ed. 1999. Alien Zone II: The Spaces of Science Fiction Cinema. London: Verso.

Landsberg, A. 2004. Prosthetic Memory: The Transformation of American Remembrance in the Age of Mass Culture. New York: Columbia University Press.

Metz, C. 1977. Le signifiant imaginaire: psychanalyse et cinéma. Paris: Union générale d'éditions.

Mikula, M. 2004. Lara Croft: Between a Feminist Icon and Male Fantasy. In Femme Fatalities. Representations of Strong Women in the Media, eds. R. Schubart and A. Gjelsik, $57-70$. Göteborg: Nordicom.

Mulvey, L. 1989 [1975]. Visual Pleasure and Narrative Cinema. In Visual And Other Pleasures. L. Mulvey. 14-26. London: Macmillan.

Penley, C., E. Lyon, L. Spiegel, and J. Bergstrom. 1991. Close Encounters. Film, Feminism, and Science Fiction. Minneapolis: Minnesota University Press.

Perkowitz, S. 2007. Hollywood Science. Movies, Science, and the End of the World. New York: Columbia University Press.

Radstone, S., ed. 2000. Memory and Methodology. Oxford: Berg.

Roberts, A. 2000. Science Fiction. London and New York: Routledge.

Silverman, K. 1991. Back to the Future. Camera Obscura 27(September): 109-32.

Simpson, M. 1993. Male Impersonators. Men Performing Masculinity. London: Cassell. Smelik, A. 2008. A Tunnel Vision. Inner, Outer and Virtual Space in Science Fiction Film and Medical Documentaries. In Bits of Life: Feminism at the Intersections of Media, Bioscience, and Technology, eds. A. Smelik and N. Lykke, 129-46. Seattle: University of Washington Press. 
Smelik, A. 2009. The Virtuality of Time: Memory in Science Fiction Films. In Technologies of Memory in the Arts, eds. L. Plate and A. Smelik, 52-68. Basingstoke: Palgrave/ Macmillan.

Sobchack, V. 1997. Screening Space. The American Science Fiction Film. New Brunswick, Rutgers University Press.

Sobchack, V. 2004. Carnal Thoughts: Embodiment and Moving Image Culture. Berkeley: University of California Press.

Springer, C. 1996. Electronic Eros. Bodies and Desire in the Postindustrial Age. Austin: University of Texas Press.

Tasker, Y. 1993. Spectacular Bodies. Gender, Genre and the Action Cinema, London: Routledge.

Walden, K. 2004. Run, Lara, Run! The Impact of Computer Games on Cinema's Action Heroine. In Femme Fatalities. Representations of Strong Women in the Media, eds. R. Schubart and A. Gjelsik, $71-90$. Göteborg: Nordicom.

Zylinska, J., ed. 2002. The Cyborg Experiments: The Extensions of the Body in the Media Age. London: Continuum. 


\section{Chapter 6: Video ergo sum: Video Art as Symbolic Form}

\section{Introduction}

By explicitly hinting in my title at Erwin Panofsky's essay "Perspective as symbolic form" (1991 [1927]), I try to understand in this article if it is possible to develop a discourse on the situation of contemporary visual culture that echoes the one proposed by the German art historian. The following arguments try to prove that it is indeed possible to do so, by referring to the relations currently binding art, aesthetics and the new media, from the interdisciplinary perspective as developed by the field of cultural studies.

Although, as correctly noted by René Berger, "neologisms are irritating" (Berger 1991, 113), they may sometimes be essential as semantic tools to build or prove a certain case. One of such neologisms is 'videomorphosis', that I will use in this article in order to validate the assumption that video is now the prevailing symbolic form of contemporary visual art. In my view, it is the symbolic form best suited to represent a quintessential "factor of style" - to use Panofsky's words $(1991,40)$ - of the current scientific and technological imagination.

In order to better define the term 'video' in this context, it could be best described as a device; a technological but also and foremost a cultural device acting in the relation of reciprocal mediation that traditionally exists between humankind and the world. A technological-cultural device with an aesthetical value is nothing but a medium, as it has been defined almost unanimously by the media studies. Yet, it is important to understand the aesthetics of video in its own right; as a way of feeling and perceiving the world, an extra-somatic extension of the human sensory network - as conceived by McLuhan - with a consequent feedback effect on humans and their 'vision of the world'. It thus pertains to the set of historical-cultural factors that twentieth century philosophers have defined as Weltanschauung.

The video-form - video as a symbolic form, or videomorphosis in this context - is moreover to be perceived as a meta-medium, a system of expressive forms, a seamless media surface shared by the different material and intellectual 
components that shape the entire contemporary cultural system. From cinema to TV broadcasting, from computers to portable devices, from video games to the electronic displays disseminated across the urban space, everything is video. Not coincidentally, the video-prefix is common to many expressions of daily language such as video-games, video-phone, video-surveillance, etc., where 'video' always stands for images shaped by movement. They form, in fact, a whirl of images flowing in a single visual stream, an unstoppable and fluid visual continuum, a form of exchange, relation, interaction between viewer and object that Nicholas Mirzoeff has defined as 'visual event' (Mirzoeff 1999, 13). Others have created even more original neologisms for this phenomenon such as 'vidéosphère' (Debray, 1992) and 'videoscape' (Canevacci 1995).

In this essay I will compare the perspective culture of the modern age and the videomorphic culture of the contemporary, postmodern, age. I thus hope to be able to highlight the specific characteristics of videomorphic culture. But let me first set out the argument of video culture as the convergence between science and visual art.

\section{Videomorphosis}

What is the role of video art today? On the basis of the arguments illustrated in this essay, I can affirm that the role of video art today is its bringing to light, its revealing the relation between symbolic culture and material culture in our age. In fact, explaining this relation, achieving this connection represents a mission shared in various ways by the entire history of art of the twentieth century; and perhaps it is a role that belongs to art tout court. In particular, video art represents a border area between several contemporary art languages. It is a constantly evolving realm within which the symbolic workings of this perceptive stream, this continuum, this visual event - vidéosphère, videoscape or whatever name one chooses for it - is revealing itself to us.

In fact, video art seems to re-run in slow motion many phenomena of contemporary visual culture that are evidence of the videomorphosis process now under way. The process I call videomorphosis is the result of the convergence of the technologies of vision conceived over the ages; it is a process that may take on any kind of form, and video art includes almost all of these forms. The symbolic value of these different artistic forms, performed in many different ways, becomes the foundation of the argument inspired by Panofsky's essay that forms the centre of this text.

Panofsky's notion of symbolic form - indebted by the positions of the Marburger Schule and its main proponent, Ernst Cassirer - has the well-known merit of having elevated a geometric-philosophical process of visual representation to 
the status of symbol. Resulting from the convergence of several theoreticaltechnical disciplines, the perspective may be viewed as a symbol in that it is an expression of a cultural construct, an arbitrary conceptual structure resulting from a historically defined and defining vision of the world. Panofsky wrote: "Indeed, [perspective] may even be characterized (to extend Ernst Cassirer's felicitous term to the history of art) as one of those 'symbolic forms' in which 'spiritual meaning is attached to a concrete, material sign and intrinsically given to this sign" (Panofsky 1991, 40 - 41). In this way a spiritual (or 'super-sensible') meaning becomes sensible, a material sign that can be experienced, a technical fact. The symbolic form has the specific advantage of reconnecting the sensible, etymologically aesthetic component of the material culture to the super-sensible (or symbolic-spiritual) component pertaining to the realm of ideas, concepts, thought or culture tout court. Moreover, the symbolic activity - or the 'symbolic faculty', as it was defined by Leslie White $(1949,33)$ - is the particular element that enables man to exist in that specifically human substrate that is culture; we may refer here to the well-known definition of man as animal symbolicum proposed by Cassirer himself (1944). The most reliable researchers on this issue (for example Durand 1964) have also suggested that symbolic forms have an arbitrary character - since their value is conferred within the cultural system that defines them as such - that is markedly historicized, or dependent on spacetemporal factors connected to a certain age or civilisation. In other words, any symbolic form is connected to, or shaped by, the cultural subsoil that produces it. As explained by René Berger: "The symbolic systems are devices that help a concept of the real become the very object of a perception from which it gets in turn its validation as a concept." (Berger 1991, 165, translation mine). For this reason, the perspective space - or, in Panofsky's words, “a fully 'perspectival' view of space" $(1991,27)$ - is not just a visual process but also a cultural device in that it connects the material dimension of Renaissance culture to the corresponding symbolic dimension, at the same time amplifying the potential of both and also influencing the entire season of Western civilisation known as the Modern Age.

If then, for the above mentioned reasons, the entire conceptual construct of perspective can be considered as a qualifying, and founding, cultural device of the Modern Age - the expression of a vision of the world and not just a visual process of technical-material nature - there is probably a similar device playing the same functional role in relation with the contemporary, or postmodern, age. In this sense, there could be no better device, no better symbolic or material form, no better synthesis of conception and perception than the video form, so much more than a technical device and so defining in its specific linguistic features. And there could be no better replacement of the perspective vision than 
the kind of vision we may precisely define as 'videomorphic', the symbolicperceptive prosthesis of contemporary man.

In order to provide evidence for this assumption, I will now indicate some functional points in common shared by the perspective vision and the videomorphic vision as well as some circumstantial differences that may support the role of video as the symbolic form of the contemporary, or postmodern, age.

\section{Similarities between perspective and videomorphic cultures}

Starting with the functional points in common, it is important to note that both perspective and videomorphic vision share a similar technological-structural dimension. In other words, visual culture of the last few centuries is deeply indebted to, and has been made possible by, scientific and technological developments. As field experts know, even the most up-to-date digital devices scanners, video- and photo-cameras used by most video makers who work with live broadcast - are based on the old principle, at least as old as perspective, of the camera obscura. It was already used by artists as early as the fifteenth century, and its principles were known since the time of Chinese philosopher Micius and of Aristotle. Today, the optical-light signals channelled in one focal point are transformed in electromagnetic impulses and then codified in the system of digital representation, essentially sharing the same basic principle that led to the invention first of photography and then of cinema. In the case of traditional photography and cinema these signals are fixed on film rather than on the electromagnetic devices used by digital products. Also, we should not forget that even the more up-to-date techniques of 3D simulation and modelling - frequently used in the production of video art - are essentially based on perspective rules and principles.

What appears evident is the common dimension shared by old and new technologies of vision, a bearing principle rooted in the governing and rationalising impulse typical of the Modern Age. The fundamental difference is that, while the perspective representation of the Modern Age relies on the artist's painterly-manual skill, with the invention of photography this process becomes mechanized, automated, relying on the intrinsic possibilities of the technical device. There is, as suggested by Lev Manovich, an additional element of continuity with the past that should not be forgotten. Even the most refined techniques of digital image processing may be interpreted as nothing but a sort of electronic painting, a technologically advanced version of the pictorial elements typical of the early expressions of cinema developed in the nineteenth century interestingly defined by Manovich as 'cinegratography' (Manovich 2001, 312). Following Manovich's arguments, we may add that a further element of con- 
tinuity between perspective and videomorphic vision is to be found in what he calls "a general tendency of the Western screen-based representational apparatus" $(2001,104)$. In fact, the screen, viewed as an interface of the videomorphic vision, as well as a mere technical device, is well-suited to represent an up-todate version of that powerful metaphor conceived during the Renaissance that is the frame/painting/window. In this regard, I can quote as example the work entitled From Alberti to The Thief created by Belgian artist Francis Alÿs in 1999 for Dia Art Foundation in New York.

A further point in common related to the cultural substrate that led to the birth of both perspective and video forms, each in its particular historical context, is the fact that both express themselves as transdisciplinary forms (Berger 1991, 165). They are the result of the intersection, convergence and exchange of disciplines and skills belonging to the technical-scientific realm as much as to the art-humanities realm and deriving from the concerted effort of artists, philosophers, engineers, scientists, mathematicians. This becomes even clearer when Jonathan Crary suggests that optical devices such as the camera obscura and the stereoscope are "points of intersection where philosophical, scientific, and aesthetic discourses overlap with mechanical techniques, institutional requirements, and socioeconomic forces" (Crary 1992, 28). In all these cases, they are not one-off inventions but the result of a shared need to express a new vision of the world. This is made clear by a series of close collaborations - also widely illustrated by Martin Kemp $(1990 ; 1999)$ - between the arts and sciences fields. If what Panofsky defines "an intuition of 'real' space" is the result of a coincidence of aesthetic taste and the particularly Italian synergy between the world of science - Leon Battista Alberti's rationalistic, geometricmathematic vision - and the world of art - the role of the Florentine Innovators, Brunelleschi, Donatello, Masaccio or Piero della Francesca -, a similar process takes place in the years of the early experiments about video. In this regard, we should not forget that video technology began with the scientific researches developed in Europe at the end of the nineteenth century; the Elektrisches Teleskop, the first electronic device that mechanically scanned moving images, was patented in 1884 by Paul Nipkow, a science student in Berlin (Briggs and Burke $2000,141)$. From that moment onwards, the following technological development proceeded in parallel with the season of Italian divisionism and French pointillisme, two movements that, while belonging to the art field, first interpreted the same processes of breakdown and scanning of the image visual and chromatic components underlying the video technology.

Having quoted Martin Kemp (1999), I want to make a brief digression on the convergence of science and visual art in the history of the Western scientific thought. Kemp underlined the paramount function of images, particularly since the Modern Age, in the processes of knowledge formation and construction. 
This role is all the more important today. As an example, we may indicate the cutting-edge techniques of simulation mostly used in the scientific field - but also in the entertainment, video game and cinema industries - to reconstruct and simulate extremely complex phenomena, models and processes. The field of simulations effectively reflects the possibility, but most of all the need, to translate, observe, manipulate in visual form what is not visual to begin with. This field has proved essential in the observation, understanding, study but also the modification of reality and its possible manifestations (Parisi 2001). During the 1990s, this area of study has evolved into the so-called 'information visualisation' (Card, Mackinlay, and Shneiderman 1999), which is the visual and interactive representation of information, data and knowledge, either real or abstract, or of not directly verifiable theories. Its field of interest is not simply visualisation - the use of images to represent existing or abstract forms of reality - but cognitive manipulation. This implies the use of images as tools for thought processing, as a sort of cognitive maps for a shared visual language; using vision to think, as suggested by Stuart Card and other researchers of the PARC (Palo Alto Research Center; see also the next essay by Michel van Dartel on recent developments in this field). We could say, instead, using video to think, as a way of reconnecting all this to the concept of videomorphosis proposed at the beginning and recognise the cognitive usefulness of video - in terms of symbolic forms on one side and of the scientific imagination on the other side - as a knowledge device typical of contemporary visual culture. This is certainly a sui generis kind of knowledge expressing itself in self-representative form that can in many ways be related to what the anthropologist Johannes Fabian has defined 'visualism', or the translation into a visual form of the experience, knowledge and understanding of a certain culture or society (Fabian 1983, 106). Here, I want to stress again the convergence between science and visual technologies.

\section{Differences between perspective and videomorphic cultures}

Let me now move on to point out the differences between the perspective and videomorphic cultures. A first important element can be found in the abandonment of the single point of view, or the renunciation of the perspective illusion first anticipated by Cubism. As Edmond Couchot (1982), among others, has remarked with reference to the ontological status of the electronic image, the expressive trend inaugurated by the Cubist school, aimed at eliminating all kinds of optical-perspective representation, conveys the reflection of a more general cultural significance. The loss of perspective was the result of a wider aesthetic research driven by the need to penetrate the essence of things and present them in their fragmentary nature. Rejecting the rationalising and totalising aspira- 
tions of the perspective culture - a single point of view - the art interventions performed in the context of video art show the typically contemporary need for visual fragmentation - several point of views; historical videos as Slow Angle Walk (1968) or Revolving Upside Down (1969) by Bruce Nauman express this concept well - resulting in the breakdown and fragmentation of the aesthetic experience in many different meaningful units. The fragments, like the pieces of a mosaic or the faces of a cube, enable the explorative and cognitive dimension of the eye to form a coherent view of space. In this regard, a perfect example is the video Sunstone (1979) by Ed Emshwiller or TV Cubisme (1985) by Wolf Voltell.

To pay homage to Cubism's conceptual heritage, what I have just described could be summarised by the antinomy between the so-called 'exogenous' function of vision - the vision from the outside - and its opposite, 'endogenous' function - the vision from the inside. In his photographic book The Medium is the Massage (1967), McLuhan wrote: “The Renaissance legacy. The Vanishing Point $=$ Self-Effacement. The Detached Observer. No Involvement! The viewer of Renaissance art is systematically placed outside the frame of experience. A piazza for everything and everything in its piazza" (McLuhan and Fiore 1967, 53). Following this intellectual stimulation, we might say that video art - as the expression of videomorphosis and the endogenous function of vision - appears to offer the viewer endless opportunities to 'get into the frame', in the sense that the visual experience, with all its aesthetic implications, becomes an exploration rather than a simple interpretation. If the perspective culture belongs to a symbolic universe where space is narrated, portrayed or represented, videomorphosis transforms the symbolic universe into something that can be accessed, explored and interacted with. Keith Sonnier expressed this concept in several video works as Positive/ Negative (1970), Tv in and Tv out (1972), Color Wipe (1973).

With regard to this, it is interesting to refer to Crary's research on optical devices and techniques, and on the forms of visual imagery in the nineteenth century, and on the stereoscope in particular. Crary sees in the stereoscope the first tool that began to express the activity of observation as an action, and more precisely as a process of immersion in what one sees, a real merging of viewer and object. "No other form of representation in the nineteenth century - Crary categorically affirms - had so conflated the real with the optical, an object with its image" (Crary 1992, 124). Therefore, the appearance of the stereoscope may represent the crucial moment of passage from the real to the optical, or from an objective kind of vision that aims at giving order to reality (perspective vision) to a subjective kind of vision that aims at building forms of thought and knowledge not constrained or necessarily subjected to reality (videomorphic vision). In this sense, I particularly refer to the study Expanded Cinema (1970) by Gene 
Youngblood and to the idea of 'expanded consciousness' he illustrates there, precisely as the result of an expanded vision (Youngblood 1970, 41).

A further element of difference between perspective and videomorphic cultures concerns the ontological status of the image itself as it is filtered, processed, mediated by a technological viewing device. In other words: the frame/painting/ window versus the screen/monitor/display. If, to quote Albrecht Dürer's words in the incipit of Panofsky's essay, the symbolic significance of perspective is based on the process of "a fully 'perspectival' view of space", when "the entire picture has been transformed into a 'window', and when we are meant to believe we are looking through this window into a space" (Panofsky 1991, 27), the video operates instead as a space that requires to be looked into in itself. The frame/ painting/window symbolising the perspective universe is an inclusive, all-embracing medium that tends to normalise and bring order to the chaos. Videomorphosis, as represented by the screen/monitor/display, acts, instead, by excluding, by cutting, thus proceeding in the opposite direction, from order to chaos. Therefore, while the theoretical approach of perspective culture hinges on the concept of representation, the foundation of videomorphic culture is reification. The former implies the transformation of one thing into an image (or video), the latter implies an image (or video) becoming a thing. This is one of the essential meanings of the videomorphosis process, that is the above mentioned connection between symbolic culture and material culture of our age. With their works, the video artists more or less voluntarily give shape to this transformation: they create new things from images. Again we can remember Vasulka's works Artifacts (1980), or Cartographie des Contrées à venir (1979) by Swiss artist Silvie Defraoui.

The comparison between perspective and videomorphic cultures would not be complete without the most significant oppositional couple expressed by sequentiality versus simultaneity. A step backwards is required at this point. McLuhan is well-known for having indicated the technological-material context where the printing process was developed as the epiphanic moment of the perspective culture. In fact, he has underlined the specific contribution given by the printing medium to the collective acceptance of the symbolic values inherent in the visual canons of the perspective space. The linearity, sequentiality, seriality, uniformity of the printed page, together with the whole set of material values related to the so-called Gutenberg Galaxy appear to be perfectly attuned to the expressions of the Renaissance Weltanschauung that gave birth to perspective. As McLuhan explained on several occasions, the printed book "intensified perspective and the fixed point of view. Associated with the visual stress on point of view and the vanishing point that provides the illusion of perspective there comes another illusion that space is visual, uniform and continuous" (McLuhan 1964, 172). The symbolic value of sequentiality in the perspective 
culture finds its counterpart in the simultaneity that is the primary element of the electronic and postelectronic galaxy. It is therefore in McLuhan's term a 'cold' medium, that is a highly participative medium like television. Simultaneity and participation are the quintessential expression of the videomorphosis process. A famous video by Urs Luthi, Self Portrait (1974), seems to show so clearly the symbolic value of simultaneity, as well as Primarily Speaking (1981) by Gary Hill or Juste le temps (1983) by Richard Cahen.

\section{Haptic visuality}

The comparison between the two symbolic universes I am considering here perspective culture (Modern Age) and videomorphic culture (contemporary age) - is also supported by several other antinomies such as natural vision versus artificial vision, manual skills versus mechanical skills, or even figuration versus abstractionism. Perspective painting is intrinsically related to the idea of natural vision, while this relation does not necessarily apply in the case of video. The automatic nature of perspective's geometric-painterly processes aims at the reconstruction of a visual experience. The video, instead, is a visual experience in itself not constrained by figuration; the well-known Global Groove (1973) by Nam June Paik is perhaps the best example of this.

Another antinomy is distance versus proximity; the former is one of the symbolic values related to the perspective culture, the latter represents an essential value of videomorphosis. I will therefore explore more fully this characteristic of video culture. Just as detaching oneself from one object and approaching it are two opposite actions, the strategy of detachment - the world seen from far away, the vanishing point as perspective's main element - has its counterpart in the approaching strategy inherent in video, the world seen from up close, in full scale, or even the intrusion that looks for the detail, the foreground, the zoom, the visual fragment, the pixel. Examples here are the first video performances by Vito Acconci, such as Open-Close (1970) or Theme Song (1973). We can find something quite similar in the emphatic and relational dimension expressed by the definition of vision or haptic space introduced further in the past by Riegl (1893) - the Latin word apto, 'touching', as opposed to traditional optical vision -, implying a vision that can even touch and establish a contact surface that is highly interactive, exploratory, penetrating. With regard to this - especially considering the Studio Azzurro's 'sensitive enviroments' as Tavoli (1995) - we could quote Deleuze and Guattari, who insist on the distinction between close-touching-vision (haptic) and disembodied-distance-vision (optic). And it is interesting to quote here their terminological clarification: "Haptic" is a better word than 'tactile' since it does not establish an opposition 
between two sense organs but rather invites the assumption that the eye itself may fulfil this monoptical function" (Deleuze and Guattari 1987 [1980], 492).

Further developing the longer critical tradition of phenomenology and sensory theory stemming from Riegl, Deleuze and Guattari, the Canadian media theorist Laura Marks proposes an updated version of the concept of haptic visuality. Her intention is:

restoring a flow between the haptic and the optical that our culture is currently lacking [...] An ancient and intercultural undercurrent of haptic visuality continues to inform an understanding of vision as embodied and material. It is timely to explore how a haptic approach might rematerialize our objects of perception, especially now that optical visuality is being refitted as a virtual epistemology for the digital age (Marks 2002, xiii).

Derrick de Kerckhove, among others, has explored this line of interpretation and, following in McLuhan's footsteps, has defined the process of almost tactile, as well as visual, intrusion brought about by the new electronic technologies. To that end he has introduced the concept of 'point-of-being' as a new type of environmental, and thus inclusive, aesthetic involvement: "My point-of-being, far from distancing me from reality as my point-of-view used to do, is my point of entry into the sharing of the world" (Kerckhove 1991, 192). Régis Debray has also chosen entry and sharing as fundamental values of a new media environment, the above mentioned vidéosphère, which marks

The end of the 'society of the spectacle' (...). We used to be in front of the image, now we are in the visual (...). The term 'landscape' was related to the eye and the term 'environment' was related to the ear. Now the visual has become an almost resounding atmosphere, while the ancient 'landscape' is a synaesthetic and embracing environment (Debray 1992, 229, my translation).

The synaesthetic vocation of videomorphosis in its manifold expressions, the first of which could rightfully be considered the production of video art and in particular of video installations, implies an involvement of the entire perceptive system, with a consequent recognition, as explained by Merleau-Ponty phenomenology, of a reciprocal subsistence of the tactile and visual spheres - " $L a$ vision est palpation par le regard" (Merleau-Ponty 1964, 177). Not coincidentally, intimacy, contact, physical dimension, corporeal involvement have long been core issues of video art production and are still its main concerns. Video art would thus seem to decree the end of visual perception's hegemony in favour of a plural, global, embracing involvement of the senses, including, according to Debray, the sense of smell $(1992,179)$. This is an evolution from the idea of (visual) landscape to that of (sound, tactile, corporeal) environment. "We are 
back in acoustic space", explained McLuhan (1969), for whom the acoustic realm had a particularly tactile, corporeal value capable of directly touching the skin and even reach the nerve-endings.

Video art's 'palpation par le regard' marks its emancipation from the mere status of moving image. It absorbs, overcomes, integrates and mocks the simply narrative dimension that is still at the core of both the cinema medium and the television environment in all its entertainment and information declinations. Instead, in its incompleteness and imperfection, in its arbitrarily low definition, it offers itself as a hybrid surface that needs to be completed, touched, interacted with, that seduces us at the sensorial rather than cognitive level. It almost fulfils the failed forecasts that were at the basis of the entire debate developed during the 1980s and 1990s about the oxymoron represented by the so-called virtual reality. The best examples of video art can be defined as virtual realities in the sense of the above mentioned reification process that transforms images into things. Such video images can generate realities that are not supposed to be seen or represented, but explored and interacted with and that stimulate all our senses, not just our cognitive functions. One example among many is The Reflecting Pool (1977) or Anthem (1983) by Bill Viola.

\section{Conclusion}

This last passage leads us back to the key concept of the videomorphosis process and the assumption that forms the core of this essay. If we accept that video is the prevailing symbolic form of the contemporary technological-cultural cycle, video art and its operators are necessarily called to reify its corresponding 'spiritual contents'. Video art can thus connect the symbolic and material dimensions of contemporary science and technology culture by using the ever changing forms and experimentations offered by the medium itself and allowed by the expressive opportunities induced by the latest image processing technologies. Video art is additionally tasked with deliberately reconnecting the sensorial - visual, sound, tactile - component of the aesthetic experience to the super-sensory, or cognitive, realm of ideas, thought, culture tout court, within the delicate, continuing process of constitution of contemporary man's Weltanschauung unavoidably related to the individual and to the self. This is precisely what the American artist and video maker Peter Campus seems to have captured in 1999 with his brilliant expression video ergo sum, that sounds laconically as 'We are what we see'. 


\section{Bibliography}

Berger, R. 1991. Téléovision. Le nouveau Golem. Lausanne: Iderive.

Briggs, A. and P. Burke. 2000. A Social History of the Media. From Gutenberg to the Internet. Blackwell, Cambridge-Oxford: Polity Press.

Canevacci, M. 2001 [1995]. Antropologia della comunicazione visuale. Feticci, merci, pubblicità, cinema, corpi, videoscape. Rome: Meltemi.

Card S.K., J. Mackinlay, and B. Shneiderman. 1999. Readings in Information Visualization: Using Vision to Think. San Francisco: Morgan Kaufmann.

Cassirer, E. 1944. An Essay on Man. Introduction to a Philosophy of Human Culture. New Haven-London: Yale University Press.

Couchot, E. 1982. La synthèse numérique de l'image: vers un nouvel ordre visual. Traverses 26: $56-63$.

Crary, J. 1992. Techniques of the Observer: On Vision and Modernity in the 19th Century. Cambridge: MIT Press.

Debray, R. 1992. Vie et mort de l'image. Paris: Gallimard.

Deleuze, G. and F. Guattari. 1987 [1980]. A Thousand Plateaus, trans. B. Massumi. Minneapolis: University of Minnesota Press.

Durand, G. 1964. L'imagination simbolique. Paris: Presses Universitaires de France.

Fabian, J. 1983. Time and the Other. How Anthropology makes its Objects. New York: Columbia University Press.

Kemp, M. 1990. The Science of Art. New Haven and London: Yale University Press.

Kemp, M. 1999. Immagine e verità. Milan: Raffaello Cortina.

Kerckhove, D. de. 1991. Brainframes. Technology, mind and business. Utrecht: Bosh \& Keuning.

Manovich, L. 2001. The Language of New Media. Cambridge, MA: MIT Press.

Marks, L.U. 2002. Touch: Sensuous Theory and Multisensory Media. Minneapolis: University of Minnesota Press.

McLuhan, M. 1964. Understanding Media. New York: McGraw-Hill.

McLuhan, M. 1969. Counterblast. Toronto: McClelland \& Steward.

McLuhan, M. and Q. Fiore. 1967. The Medium is the Massage. An Inventory of Effects. London and New York: Bantam Books.

Merleau-Ponty, M. 1964. Le visible et l'invisible. Paris: Gallimard.

Mirzoeff, N. 1999. An Introduction to Visual Culture. London: Routledge.

Panofsky, E. 1991 [1927]. Perspective as Symbolic Form, trans. C.S. Wood. New York: Zone. Parisi, D. 2001. Simulazioni. La realtà rifatta nel computer. Bologna: il Mulino.

Riegl, A. 1893. Stilfragen. Grundlegungen zu einer Geschichte der Ornamentik. Berlin: Siemens.

White, L. 1969 [1949]. The Science of Culture. A Study of Man \& Civilization. New York: Farrar, Strauss and Giroux.

Youngblood, G. 1970. Expanded Cinema. New York: P. Dutton \& co. 


\section{Chapter 7: Enactive Media: A Dialogue between Psychology and Art}

\section{Introduction}

Art has a long history of interaction with psychology. This is not surprising given the observation by Friedlander that "Art being a thing of the mind, it follows that any scientific study of art will be psychology" (in: Gombrich 1977, 3). A notable example is the dialogue between the visual arts and the psychology of perception. In this dialogue, however, art serves a merely instrumental role in the support and development of theory on perception; pictorial artworks are for instance discussed in support of representational theory of perception. Examples of the inverse - artistic work that utilises theory of perception for the development of new artistic experiences - are very scarce. I do believe that a mutually beneficial dialogue between art and psychology is nevertheless possible and I hope to illustrate this through a discussion of artistic research and development (aRt\&D) in the field of media art (Brouwer et al. 2005). The essay will show how some instances of media art allow for the remediation of recent theory of perception through art, while this same theory in turn opens up new horizons for artistic exploration.

\section{The Enactive Approach and Media Art}

Recent theory of perception is based on the idea that a perceiver enacts perceptual experiences, i. e. that perceptions are actions (Noë 2004). This approach is referred to as the 'sensorimotor coordination approach' (O'Regan and Noë 2001) as well as the 'enactive approach' (Varela et al. 1991), which I will use interchangeably in this essay. ${ }^{1}$ The approach takes the basic premise that: "To be a perceiver is to understand, implicitly, the effects of movement on sensory

1 Putting aside several differences that were recently revealed between the two notions (Taraborelli and Mossio 2008). 
stimulation" (Noë 2004, 1). This idea is a radical paradigmatic shift away from the conception that perception is based on the passive processing of information (Marr 1982) and the construction of internal representations (Pylyshyn 2007), which has dominated the psychology of perception for many decades.

The sensorimotor coordination approach attributes a fundamental role to the body of the perceiver during perception, whereas in prior theories of perception most emphasis was placed on the brain and its internal processes. Although empirical support for the enactive approach is steadily growing within the cognitive sciences community (see, for example, Noë 2004, O’Regan and Noë 2001, and Van Dartel 2005), the approach remains generally unnoticed within many of its potential application domains, such as the field of media art. This is remarkable, given that in media theory and design much emphasis is placed on the interfacing between media and its users. In new media for instance, which transforms viewers into active users (Manovich 2001), the user's body is designated an active role in the media experience (Wegenstein 2006; Munster 2006; and Hansen 2006). A few exceptions can be found where the enactive approach is related to media art, such as Hansen's 'New Philosophy for New Media' (2004). Hansen argues that new media's interactive qualities allow for the body to serve as a framing function, which yields what he calls 'the digital image': the entire process by which information is made perceivable. In Hansen's view, this process is determined by our sensorimotor embodiment in interaction with new media, rather than by passive reception (here he refers to Varela's notion of embodiment; Varela et al. 1991). In other words, Hansen claims that new media experiences are shaped by the bodily actions that constitute our perception, that is, by our sensorimotor coordination. This implies that new media experiences cannot be considered separately from the body and the sensorimotor processes in the interaction between body and media. Therefore, insight into the enactive approach is crucial to the understanding of new media experiences.

On the basis of a series of new media designs, Krueger (2007b) recently demonstrated that the reverse is also true: media design can play an important role in the construction of the enactive approach. He argues that "design work based on enactive cognition [...] can re-inform and reinforce the theory by the introduction of novel perceptual phenomena that cannot be accommodated within the standard view of perception" (Krueger 2007b, 1393).

Taken together, Krueger and Hansen's claims, briefly outlined above, indicate that a mutually beneficial dialogue is possible between psychologists, studying the enactive approach, and new media artists. A dialogue in which media artworks can be made instrumental to the enactive approach, while theory on the approach is simultaneously employed to open up new horizons for artistic research and development into media experiences. Such a mutually beneficial exchange may connect body and media in ways that would be inconceivable 
without a dialogue between the divergent disciplines of psychology and media art. After a brief introduction of the principles underlying the enactive approach, this essay will describe several important examples that clearly illustrate how media art and the enactive approach come together in what I will coin as 'enactive media'.

\section{Sensorimotor Coordination}

Sensorimotor coordination, the main principle underlying the enactive approach, has been intensively researched in recent years, producing a wealth of important studies and literature on the subject. A brief discussion of the general mechanism will however suffice for the purpose of this article. Theory on sensorimotor coordination states that conscious perception emerges from interaction with the environment. More precisely, it says that we make sense of the world around us by exploiting the consistencies in the perceptual changes that result from our own physical interactions with our surrounding environments. An example discussed by O'Regan and Noë (2001) illustrates what this means exactly.

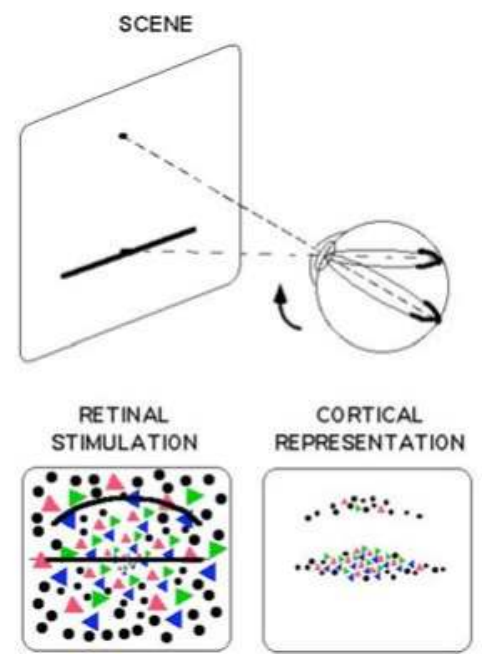

Figure 7.1 Courtesy O'Regan and Noë (2001). Re-printed with permission from author (O’Regan).

"The eye fixates the middle of a straight line and then moves to a point above the line. The retinal stimulation moves from a great arc on the equator of the eye to a different, smaller great arc. [...] If the eye moves along the straight line instead of 
upwards, there would be virtually no change at all in the cortical representation. [...] This is the idea underlying the theory that shape in the world can be sensed by the laws obeyed by sensorimotor contingencies" (Noë 2004, 941).

Let us presume that the eye in Fig 7.1 (top right) is one of your eyes. If you move your eye's focus upward a little, from fixating your eye on a straight line to fixating it at the space just above that straight line (top left), then you will still see a straight line although the stimulation of your eye's retina is now actually bent. Since the light-sensitive cells on the back of your eye (that make up your eye's retina) are positioned on the curved inner surface of your eye, the focal shift of your eye resulted in a change of retinal stimulation from a great arc on the equator of your eye (if we would flatten our retinas this would form a straight line, as in Fig. 7.1) to a different smaller great arc above it (bottom left). (The triangles and dots in Fig. 7.1 represent colour sensitive and light sensitive cells on the retina.) The stimulation of neurons in our brain, i.e. the 'cortical representation' (bottom right), changes accordingly.

After looking at Fig. 7.1, an obvious question may arise that has puzzled many psychologists and philosophers in the past: if the retinal stimulation bends, when moving our eye's fixation upwards from the line, then why don't we perceive a bent line? The answer to this question illustrates the most important and fundamental principle of sensorimotor coordination: we (still) perceive a straight line when moving our eyes' fixation, because the motor action - the upward motion of our eye - results in this change in stimulation of our retinas. If we had moved our eye sideways instead, this change would not have occurred; in fact, in that case, no change would have occurred. Or, if the line had been curved instead of straight, then the relation between our eye's movement and the sensory change that movement produced would have been completely different. Hence, we would not have experienced 'straightness'. When we move our eyes over a straight line in a certain way, it always consistently results in sensory changes typical for straightness.

This means that the change in sensory information is invariant to the movement of our eyes. Such invariant relations between our motor behaviour (e.g. moving our eye) and the resulting sensory changes (e.g. changing retinal stimulation) are therefore referred to as 'sensorimotor contingencies'. By acting in the world we gain implicit understanding of the sensorimotor contingencies that typically occur in interaction with physical characteristics (such as colours, shapes and movements). It is this implicit understanding that results in conscious experience of these characteristics whenever our senses interact with them again. In the straight-line example above, the sensorimotor contingencies that typically occur in interaction with straight lines are exploited to experience straightness. 
One particularly strong empirical finding, which shows the importance of eye movement for visual perception, is that when eye movement is prevented completely (stabilising a scene on the retinas), vision fades away (Ditchburn and Ginsberg 1952). In accordance with the sensorimotor coordination approach described above, this blinding effect follows logically from stabilising a retinal image, because such stabilisation takes the bodily action (eye movement) out of the sensorimotor interaction with our surroundings. In other words, retinal stabilisation takes the action out of the sensorimotor loop: no eye movement means no sensory change resulting from movement, and therefore no sensorimotor contingencies to be exploited.

Although in the above the focus is on visual perception, it is important to note that the principle of sensorimotor coordination is also relevant for explaining perception through all other sensory modalities. For instance, try feeling a surface by only pushing your fingertip against it. It will not work. The surface can only be perceived through the tactile sensors on your fingertip when rubbing your finger over the surface. The reason for this is exactly the same as for the blindness effect that occurs when images are stabilised on our retinas: perception is active, it requires movement of the senses (or, alternatively, movement of the stimulus) and its resulting sensory change to allow exploitation of sensorimotor contingencies.

\section{Examples from Artistic Research and Development}

As mentioned above, Krueger (2007b) recently argued that artistic research and development into media experiences could play a critical role in the construction of the enactive (or sensorimotor coordination) approach. He supported this argument with the design of a series of new media devices. Hansen (2004) also grounded his 'new philosophy for new media' in examples from artistic research and development, and finds his most illustrative examples in the field of virtual reality (VR) art. Therefore, I will discuss two examples from the domain of VR art to illustrate which type of media is of interest to the scientific study of the enactive approach: DEVMAP and Exercise in Immersion 4 (EI4).

DEVMAP was developed by the artist collective Workspace Unlimited and was commissioned by V2_Institute for the Unstable Media for the Dutch Electronic Art Festival (DEAF) in 2004. The VR installation of DEVMAP and its users' interaction with the installation are typical for many VR artworks: a user stands in front of a screen that is placed a few meters away from him or her and controls the movement (walking) of an avatar in a projected virtual world by moving a mouse (walking direction) and by pressing the left or right mouse buttons (forward or backward walking, respectively). The structure of the 
DEVMAP virtual world is made up of data (audio, video, and text), which can be streamed live into the virtual world, as was done during the DEAF 2004 (see Fig. 7.2).
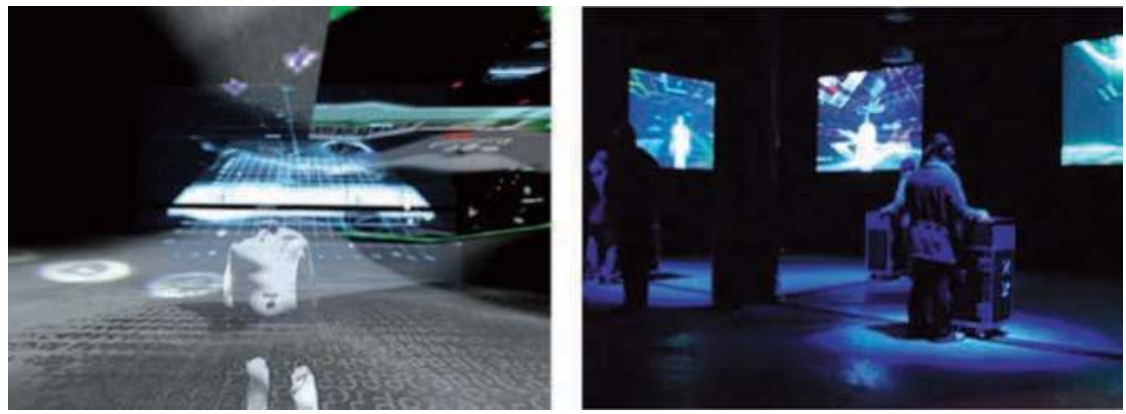

DEVMAP by Workspace Unlimited. Left (7.2a): A data landscape of live fed media. Right (7.2b): Users explore the DEVMAP virtual world by moving avatars on the screen from one of the installation's consoles. Courtesy Workspace Unlimited, 2004.

Upon a user's first interaction with the DEVMAP virtual world, navigation through the environment feels more like scrolling through a text document than like walking through a landscape. The sensation of reality experienced while interacting with the DEVMAP virtual world, eventually does grow on a user after a period of actively engaging with it. Nevertheless, even after long periods of interaction with the DEVMAP virtual world, the experienced sensation is still not comparable to the sense of reality experienced in the real world. The reason for this can be found in the principle of sensorimotor coordination described above: the only sensorimotor relation that is controlled by the DEVMAP installation, is the relation between a user's hand movement (moving the computer-mouse) and the resulting changes on the screen in front of him or her. If any sensorimotor contingencies can be found in this limited interaction, they will likely be quite different from the contingencies that our perceptual systems exploit on a daily basis.

Without implying any judgment on the aesthetical quality of DEVMAP, the example shows how poor use of the principle of sensorimotor coordination in media art leads to a lack of experienced realism by the user. Consequently, media installations such as DEVMAP (a typical VR set-up) are of little interest to the scientific study of the enactive approach. I will now further justify this statement by using a counterexample.

My second example of VR art, EI4, is of interest to the scientific study of the enactive approach. EI4 is a spectacular artistic endeavour into creating an artgame using augmented reality (AR). AR is a particular instance of VR, in which a user's real surroundings are only partially overlaid with virtual elements. EI4 
was first demonstrated as a prototype at the Dutch Electronic Art Festival (DEAF) 2007, where a deserted storage building was used as the real surrounding to overlay with simulated elements (see Figures 7.3a and 7.3b).

In EI4, a player wears a specially designed Head-Mounted Display (HMD) and a crash-suit. The HMD has a sensor system that connects the position of a player with previously modelled visuals. A player starts the game in common reality (see Fig. 7.3a, left), but as he/she progresses in the game the common reality is increasingly taken over by virtually simulated elements. The goal of the game is to collect 'bionts', small virtual balls that float around in the air (see Fig. 7.3b, right). The collected bionts gather in front of the player, and bounce off real and virtual obstacles. When enough bionts are collected, the player progresses to a next level in the game. With every subsequent level, the player is more exposed to a virtual world, which means that the virtual reality gradually takes over from the common reality. At later stages in the game, the virtual world even completely occludes the real world, and real-world obstacles are no longer visible to the player. At this point in the game, the bionts serve as a navigational aid to the user to avoid crashing into obstacles (such as walls and pillars) in the real world.
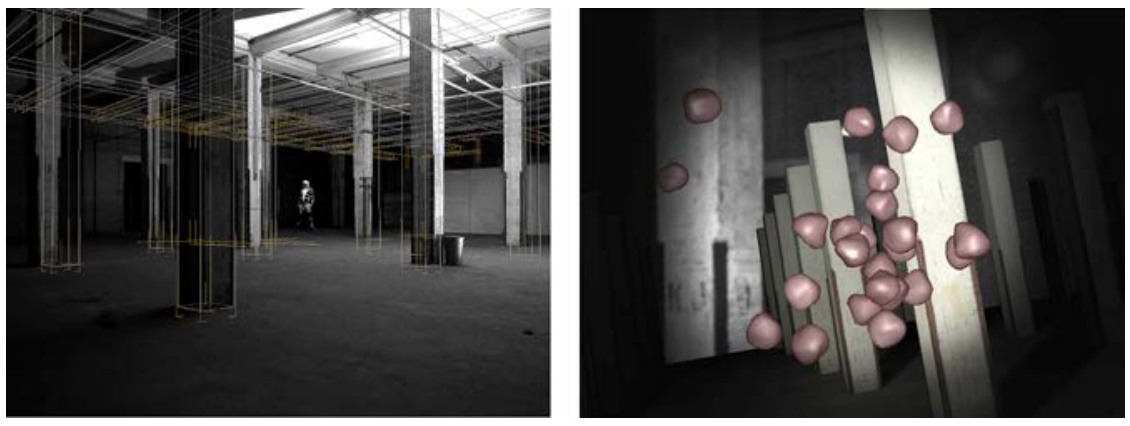

Exercise in Immersion 4 by Marnix de Nijs and V2_Lab. Left (7.3a): The common reality is modelled in a 3D model. Right (7.3b): Simulated elements, called 'bionts', overlay the common reality. Courtesy: V2_.

Upon entering the EI4 augmented game world, it becomes clear that the Augmented Reality environment provides a much stronger sense of reality than the Virtual Reality environment of DEVMAP. Of course, the rather sophisticated technology used in the installation, such as the $3 \mathrm{D}$ engine and the immersive projection technology, can be taken as the reason for this difference in experience. However, the AR technology itself does not explain the experience. The technology used in EI4 can only establish such a realistic experience because it allows for sensorimotor invariants to exist in the user-system interaction. In other words, the technology establishes invariant relations between the movement of a user and the resulting changes projected inside the HMD. Hence, it 
allows exploiting sensorimotor contingencies which are either learned anew or that users are already familiar with from the real world, as we will see below.

The main problem with AR, however, is that the sense of reality in AR artworks strongly depends on the level of synchronisation between the simulated elements and the real world. If the overlay of simulated elements runs asynchronous with the real world, then the invariants that the user relies on to make sense of reality become variant; all contingencies in the sensory change resulting from movement are gone. In that case the sense of reality is immediately lost (Van Dartel 2009; Van Dartel et al. 2007). Synchronisation of the simulated elements with the real world also poses the main technical challenge to AR, since in order to do so the movement of a user needs to be very precisely tracked. However, when the modelling is detailed and correct and the synchronisation is successful, then the virtual elements overlaying the real surroundings in EI4 are perceived exactly as they would be, were they objects in the real world. This is the case because a user's sensorimotor interaction can exploit the same contingencies as in interaction with comparable objects in the real world. The next section will explain this in more detail and will discuss why in this case we may call the media 'enactive'.

\section{Enactive Media}

The difference in new media experience between DEVMAP and EI4 can best be explained using an elementary example: perceiving a red ball. Explained in terms of the principle of sensorimotor coordination described above, we perceive a red ball using our implicit understanding of the visual sensory changes that occur when moving our eyes' fixation over red round surfaces: the change in stimulation of our retinas as a result of a certain eye, head and body movement obeys the contingencies typical for 'redness' and 'roundness'.

To perceive a red ball on either the DEVMAP screen or the displays inside the HMD of EI4, a user exploits sensorimotor contingencies between eye movement and the visuals on the screen(s). These contingencies are however typical for 2D representations of a red ball, rather than contingencies typical for a real red ball. ${ }^{2}$ Nevertheless, a virtual red ball is also perceived in EI4 through the change in stimulation of our retinas resulting from additionally moving our head and body around the object, given that head and body movement also change the focus of

2 According to Hesslow's (2002) 'simulation hypothesis', one may however need to internally simulate the sensory effects of moving his/her eyes over a real red round surface to interpret a textual or 2D representation of a red ball. Empirical evidence in support of this hypothesis can be found in Van Dartel and Postma (2005). 
our eyes. The contingencies in this sensorimotor relation are (modelled to be) similar to those typical for redness and roundness in the real world. Therefore, a virtual red ball in EI4 would, at least in part, be experienced similarly to how a red ball in the real world is perceived. In contrast, DEVMAP does not obey any of these real-world invariants for redness and roundness. The only co-determinant of retinal sensory change in DEVMAP is the computer-mouse movement that changes the user's viewing angle. This sensorimotor eye-hand relation is however nonexistent in the real world, and arguably without invariants. ${ }^{3}$

To summarise, the main difference between the new media experiences of DEVMAP and EI4 is that EI4 obeys sensorimotor invariants that occur in the real world, whereas DEVMAP does not. The latter explains why users experience the augmented reality of EI4 as much more realistic than the virtual reality of DEVMAP (Van Dartel et al. 2007). In this sense, EI4 may be said to make particularly good use of the principle of sensorimotor coordination; its new media design facilitates experiences that in terms of enactive processes are similar to perceiving the real world, and are therefore experienced as realistic (Van Dartel 2009).

Real-world sensorimotor invariants can be obeyed in EI4, because the installation's technology controls the sensory change resulting from a user's body movement, and uses this control to mimic the visual changes that would occur in the real world. Media that have such control over sensory changes resulting from bodily movement may be called 'enactive media' because they can mediate the enactive processes taking place in perceiving their content. While other types of media merely control the output of content, enactive media can establish invariant relations between bodily movement and this output.

Traditional media, such as books and films, are also perceived on the basis of sensorimotor contingencies, occurring in interaction with respectively words and moving images, but they do not qualify as enactive media, because they do not mediate enaction. When a reader or viewer of the medium moves his or her eyes over a page or image, the medium has no control over the changes that this movement results in on the user's retinas. The DEVMAP example showed that even new media with tangible interactive interfaces might not qualify as enactive media. Such interactive interfaces may control the display of content in response to movement, but that does not automatically mean that they can establish invariant relations between this movement and the output displayed. From the display onwards, such media moreover have no (or poor) control over the changes that bodily movements result in on the retinas, ears, skin, etc. of the user, and therefore do not mediate the enactive processes taking place.

3 Since a user's position relative to the screen will always slightly vary, the same motor actions (mouse movement) will likely result in variant sensory changes (changes on the retina). 
The control over sensory change that is typical for enactive media does not, however, necessarily have to be used to mimic real-world sensory changes (as in the case of EI4). Such control can also be applied to create new invariant sensorimotor relations between a user's body and the medium. In that case, a user should be allowed time to gain implicit understanding of the new sensorimotor invariants occurring in the interaction, after which the medium can mediate enaction on the basis of these newly learned contingencies. I will illustrate how enactive media can be used as such, by describing the classic 'vision substitution' experiments conducted by Bach-y-Rita and his colleagues (Bach-yRita et al. 1969; Bach-y-Rita 1972). In these experiments, vision is substituted by vibration on the skin. This is done by precisely translating contours in video images, received through small cameras attached to glasses, into vibrations on the skin, produced by a matrix of small vibrators (see Fig. 7.4).

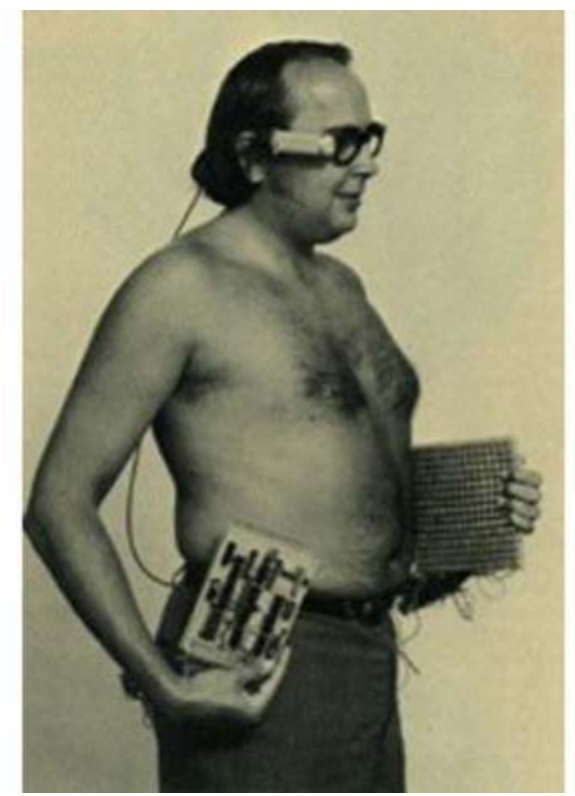

Figure 7.4: Sensory substitution device for haptic vision by Bach-y-Rita (1972).

The result is a phenomenon often referred to as 'haptic vision'; the experience of seeing with one's skin, which was reported by Bach-y-Rita's experimental subjects after sufficient training. The medium used in these vision substitution experiments (the substitution device) controls the conversion of visual into tactile stimulation in such a way that it allows for the exploitation of consistencies in the relation between head movement and stimulation by the tactile display. Particularly interesting about Bach-y-Rita's substitution device is that 
the device establishes a sensorimotor relation that is nonexistent in the real world. However, the sensorimotor relation between head-movement and tactile sensory change (contours translated into vibrations) established by Bach-yRita's substitution device is straightforward enough to only require some training (typically 10-15 hours) to implicitly understand the sensory effects (changes in tactile sensory stimulation) of head movements (Krueger 2007a). In this case, a user can in several hours time gain an implicit understanding of the sensorimotor contingencies that the medium obeys, and immediately afterwards exploit these contingencies for haptic vision. ${ }^{4}$ The medium thus mediates enaction on the basis of these newly learned contingencies, and therefore qualifies as enactive media. ${ }^{5}$ DEVMAP, for example, cannot mediate enaction on the basis of newly learned contingencies, because there are (arguably) no invariants in the computer mouse interaction, which implies that there are no new contingencies to be implicitly learned.

On the basis of the above, we can establish that enactive media use their control over sensory change resulting from bodily movement to mediate enaction. In other words, enactive media establish invariant relations between bodily movement and sensory change for the user to exploit. Such media can either mediate enaction by establishing user interaction that obeys firstly sensorimotor contingencies that occur in the real world, or secondly sensorimotor contingencies that are straightforward enough for an implicit understanding within the time a user is typically engaged with the medium. In both cases, the media experience will feel realistic, because the sensorimotor contingencies exploited to perceive the medium are either commonly exploited in real-world perception or can be implicitly understood. Such enactive media are of interest to scientific experimentation into the enactive approach, because they establish real-world perception under controlled conditions.

\section{Directions for Scientific Experimentation with Enactive Media}

To create enactive media basically means to design the sensory consequences of a user's bodily movement in interaction with the medium. As the previous section showed, in a successful enactive media design, a user can either exploit sensorimotor contingencies that are commonly exploited in real-world per-

4 Haptic vision can now also be experienced almost instantly using a device called The Enactive Torch (Froese and Spiers 2007; Grespan et al. 2008). This device establishes a relatively straightforward relation between changes in physical distance (measured through ultrasonics) and variations in vibration of the torch.

5 More examples of tactile enactive media can, for instance, be found in the domain of forcefeedback systems research (Burdea 1996). 
ception, or the design allows the user to gain implicit understanding of new sensorimotor contingencies. In both cases, the designer or artist achieves this on the basis of control over the sensory consequences of a user's movement in interaction with the medium. These sensory consequences of movement are typically controlled through computer hardware and software, which moreover provides very detailed control. To cognitive psychologists, such detailed control over sensory change as a result of movement is highly desirable, as research has shown that much can be learned about enactive processes by manipulating the sensory consequences of movement (Bompas and O'Regan 2006a; 2006b; Kohler 1961).

Most of the devices currently in use to conduct such manipulations, share strong similarities with those used in a range of classic experiments reported by Kohler (1961). In these experiments, Kohler for instance equipped goggles with mirrors that altered the visual consequences of moving the eyes: reversing left and right, or down and up perspectives (see Fig. 7.5a, left). The adaptation to the reversed perspectives that Kohler's goggles resulted in (and recent reproductions of Kohler's goggles, such as Carsten Höller's Umkehrbrille in Fig. 7.5b, right), are now widely taken as proof that perceivers "must possess and make use of sensorimotor knowledge" (Noë 2004, 10). Also, experimentation with such goggles has provided much insight into the nature and acquisition of sensorimotor contingencies (see Bompas and Regan 2006b).

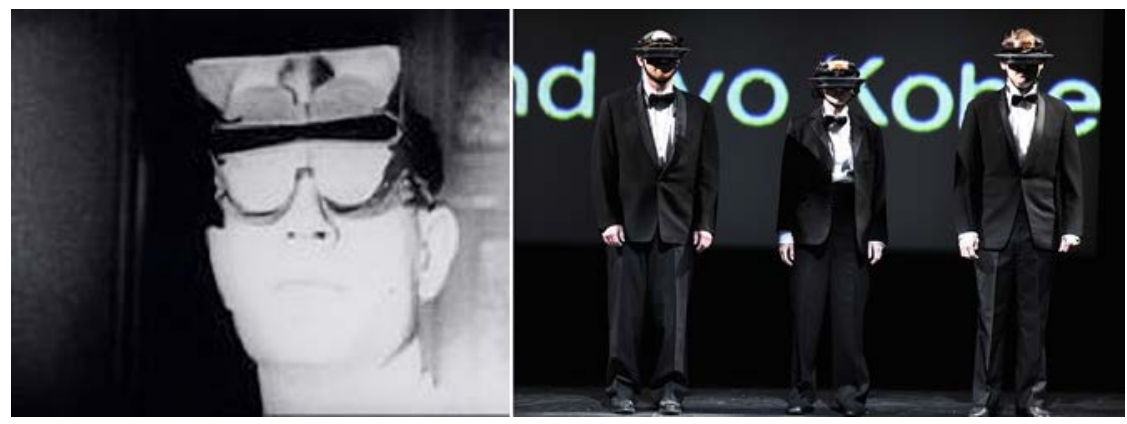

Inverting glasses by Ivo Kohler (1962, 7.5a, left) and Upside Down People by Carsten Höller (2009, 7.5b, right). Il Tempo del Postino, Basel 2009. Photo by Peter Schnetz. Courtesy Carsten Höller.

Enactive media such as the AR installation EI4 can be amended fairly easily to create such 'reversed world' experiences. In addition, such enactive media applications may allow for a much more refined control over when and at which angles the reversion of perspectives occurs. The latter aspect could, for instance, realise the desire expressed by O'Regan and Noë's (2001) to have subjects in reversed world experiments gradually learn to invert their mental picture of the 
world, in contrast to the immediate shift in perspectives established by current (analogue) inverting glasses. In theory, all of Kohler's goggle experiments could be reproduced using enactive media, with much more control over the experimental parameters.

In 2001, Susan Blackmore reported three experiments that could subject the sensorimotor coordination approach to direct verification: scrambled vision, manual vision, and blinded vision (Blackmore 2001). Although received with much enthusiasm, the experiments proved difficult to conduct due to the technologically complex installations required for their realisation. The main obstacle to their realisation seems to be the problem of controlling sensory changes resulting from bodily movement. Given the above, this obstacle could be tackled by establishing a dialogue between media artists and cognitive psychologists in the creation of enactive media.

On the basis of these opportunities for empirical experimentation into the enactive approach, it seems that enactive media artworks should be of great interest to the scientific community concerned with the enactive approach. However, would this (again) result in a dialogue in which art is merely made instrumental to the sciences?

\section{New Horizons for Artistic Exploration}

Krueger states that what I have termed 'enactive media' "may also open new aesthetic territories to investigation" $(2007 \mathrm{a}, 136)$. This means that scientific insight into the enactive approach could also be made instrumental to the arts rather than only the other way around. Examples of enactive media in the scientific realm indicate that theoretical insight into the enactive approach may lead to the creation of tools that could easily be adopted in the arts to create novel artistic experiences. Such experiences may range from visually realistic AR experiences (Munster 2006) to revealing unperceivable real-world information (Krueger 2007a) and the substitution of our senses (Bach-y Rita et al. 1969; Froese and Spiers 2007; Grespan et al 2008). However, artists do not have to use theoretical insight into the enactive approach to recreate real-world experiences, as the control over sensory change in enactive media could just as well be used to create surreal sensory experiences through creative experimentation. In fact, the latter is much more common in artistic practices than the first (Kroker 2004). In the remainder of this section, I will propose an enactive media project to illustrate how this can be done.

We have seen above that when someone's eyes are completely refrained from movement, resulting in the stabilisation of an image or scene on the retina, the person's vision fades away. Such stabilisation takes the action out of the sen- 
sorimotor loop that constitutes our perception. No action results in no effects of movement on sensory stimulation. In theory, the reversal should have the same effect in the following case: when one would move an image in perfect correlation to the movement of a person's eyes, this image is also stabilised on the person's retinas, and should therefore become invisible to that person. This method is named 'Image Fixation' (Van Dartel 2009), and its basic idea is depicted in Fig. 7.6.
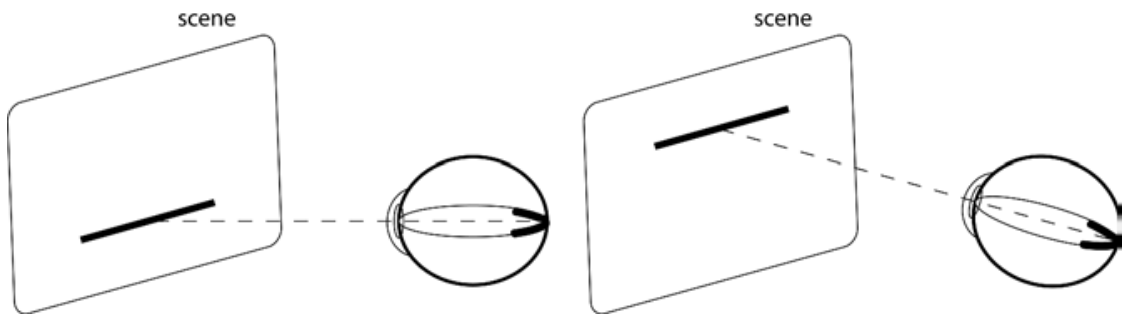

Adapted from Fig. 7.1 by Michel Van Dartel.

Example of 'Image Fixation'. An eye fixates the middle of a straight line (7.6a, left) and then moves to a point above the line (7.6b, right). When the line is subjected to 'Image Fixation', the line moves accordingly and is repositioned at the new point of fixation. The retinal stimulation remains unchanged; a great arc on the equator of the eye occurs in both fixations. Following the sensorimotor coordination approach, the line will be invisible to the perceiver, because the action has no effect on the sensory stimulation received.

The enactive media design that I propose in Fig. 7.6 is one that establishes a oneto-one mapping between the movement of a user's eyes and the coordinates at which an image is projected, i.e. between eye movement and received visual sensory change. The sensory change in this design is always zero as long as we reposition the same image according to the eyes' focus. Such a one-to-one mapping can be achieved by precise tracking of the user's eye movement, using an eye-tracking device and software that continuously repositions the image to the new coordinates on which the user's eyes are focused. When the eye tracking and the repositioning of the image are carried out in a speed that is near to realtime, then the user will be blind to the projected image. At the same time, anyone else observing the same scene will witness a moving image. In practical terms, such a media design could for instance censor certain visual content for one specific user, while keeping it accessible for others, while all are looking at the same screen.

Following Kroker $(2004,205)$ in that "media art is about enhanced perception" and that its point is "not to mimic mass media aesthetics, but to break its spell", 
we may consider this hypothetical project to illustrate the strong potential of theoretical insight into the enactive approach for media art.

\section{Conclusion}

In line with Hansen's view (2004) that sensorimotor embodiment plays a crucial role in the perception of new media content, the media artworks discussed in this essay illustrate how the principle of sensorimotor coordination and hence, of the body, shapes our perception of new media. It was also revealed that a subset of new media applications, enactive media, are of particular relevance to the psychology of perception, and that useful examples can be found in the field of media art. Enactive media thus do not only offer new directions for scientific research, but also new possibilities for artistic exploration through theoretical insight. Therefore, I strongly advocate a mutually beneficial dialogue between psychologists studying the enactive approach and media artists, which could be established through a collaborative study and design of enactive media. Such a dialogue may achieve three things: connect body and media in new ways, remediate theory accumulated in the enactive approach, and create new media art experiences.

\section{Bibliography}

Bach-y Rita, P., C. Collins, F. Saunders, B. White, and L. Scadden. 1969. Vision by Tactile Image Projection. Nature 221(5184): $963-64$.

Bach-y-Rita, P. 1972. Brain Mechanisms in Sensory Substitution. New York: Academic Press.

Blackmore, S. 2001. Three Experiments to Test the Sensorimotor Theory of Vision. (Commentary on O'Regan and Noë) Behavioral and Brain Sciences 24(5): 977.

Bompas, A. and J. O’Regan. 2006a. More Evidence for Sensorimotor Adaptation in Colour Perception. Journal of Vision 6(2): 145-53.

Bompas, A. and J. O’Regan. 2006b. Evidence for a Role of Action in Colour Perception. Perception 35(1): $65-78$.

Brouwer, J., A. Mulder, and A. Nigten, eds. 2005. aRtઐD, Research and Development in Art. Rotterdam: NAi / V2_.

Burdea, G. 1996. Force and Touch Feedback for Virtual Reality. New York: Wiley Interscience.

Dartel, M. van. 2005. Situated Representation. Maastricht: Maastricht University Press.

Dartel, M. van. Forthcoming. Truth in Media Art through Sensorimotor Coordination. In Monitoring scenography 2: Space and Truth, eds. T. Brejzek and W. Greisenegger.

Dartel, M. van, and E. Postma 2005. Symbol Manipulation by Internal Simulation of Perception and Behaviour. In Proceedings of the Fifth International Workshop on Ep- 
igenetic Robotics: Modelling Cognitive Development in Robotic Systems, eds. L. Berthouze, F. Kaplan, H. Kozima, H. Yano, J. Konczak, G. Metta, J. Nadel, G. Sandini, G. Stojanov, and C. Balkenius, $121-24$. Lund: Lund University Press.

Dartel, M. van, J. Misker, A. Nigten, and J. van der Ster. 2007. Virtual Reality and Augmented Reality Art Explained in Terms of Sensorimotor Coordination. In Proceedings of $4^{\text {th }}$ International Conference on Enactive Interfaces, eds. Luciani, A. and C. Cadoz, 417 - 20. Grenoble: Association ACROE.

Ditchburn, R. and B. Ginsberg. 1952. Vision with a Stabilized Retinal Image. Nature 170: $36-37$.

Froese, T. and A. Spiers. 2007. Toward a Phenomenological Pragmatics of Enactive Perception. Cognitive Science Research Papers 593.

Gombrich, E. H. 1977. Art and Illusion: A Study in the Psychology of Pictorial Representation. London: Phaidon Press.

Grespan, L., T. Froese, E. Di Paolo, A. Seth, A. Spiers, and W. Bigge. 2008. Investigating the Role of Movement in the Constitution of Spatial Perception Using the Enactive Torch. In Enactive/08: Proceedings of the 5th International Conference on Enactive Interfaces, 105 - 10. Pisa: Edizioni ETS.

Hansen, M. 2004. New Philosophy for New Media: A New Philosophy for a New Media. Cambridge, MA: MIT Press.

Hansen, M. 2006. Bodies in Code. New York: Routledge.

Hesslow, G. 2002. Conscious Thought as Simulation of Behaviour and Perception. Trends in Cognitive Science 6: 242-47.

Kohler, I. 1961. Experiments with Goggles. Scientific American 206: 62 - 72.

Kroker, A. 2004. The Will to Technology and the Culture of Nihilism. Heidegger, Nietzsche, and Marx. Toronto: University of Toronto Press.

Krueger, T. 2007a. Devices for the Perception of Magnetic Fields. In Proceedings of $4^{\text {th }}$ International Conference on Enactive Interfaces, ed. A. Luciani and C. Cadoz, 133-36. Grenoble: Association ACROE.

Krueger, T. 2007b. Design and Prosthetic Perception. Kybernetes: The International Journal of Systems \& Cybernetic 36(9-10): 1393-1405.

Manovich, L. 2001. The Language of New Media. Cambridge, MA: MIT Press.

Marr, D. 1982. Vision: a Computational Investigation into the Human Representation and Processing of Visual Information. San Francisco: Freeman and Co.

Munster, A. 2006. Materialising New Media: Embodiment in Information Aesthetic. Hanover: University Press of New England.

Noë, A. 2004. Action in Perception. Cambridge: MIT Press.

O'Regan, K. and A. Noë. 2001. A Sensorimotor Account of Vision and Visual Consciousness. Behavioral and Brain Sciences 24(5): 939 - 1011.

Pylyshyn, Z. 2007. Things and Places: How the Mind Connects with the World. Cambridge, MA: MIT Press.

Taraborelli, D. and M. Mossio. 2008. On the Relation Between the Enactive and the Sensorimotor Approach to Perception. Consciousness and Cognition 17(4): 1343-44.

Varela, F., E. Thompson, and E. Rosch. 1991. The Embodied Mind: Cognitive Science and Human Experience. Cambridge, MA: MIT Press.

Wegenstein, B. 2006. Getting Under the Skin: Body and Media Theory. Cambridge, MA: MIT Press. 
Edyta Just

\section{Chapter 8: The Positive Potential of IVF in Visual Culture}

\section{Introduction}

The encounters between the human body and technologies that take place within medical situations have evoked various discussions among academics. ${ }^{1}$ These debates regard not only the very nature of those encounters, but also stand for deliberations on the contemporary status of the human subject and, so to say, a general condition of living humans. Technology and the human body are regularly approached as two ontologically different, thus radically opposite units, and as such human-technology interactions are usually seen in terms of binary oppositions.

This logic leads to two kinds of approaches. On the one hand, human-technology encounters are enthusiastically approached as enhancing the possibilities of the human body. The technology becomes glorified and the body runs the risk of, or is already undergoing, degradation and a peculiar abandonment. The body appears to get a status of nothing more than an unnecessary burden, an imperfect relic, and at best, the object of jokes, whereas the techno-world appears to bring great solutions and be all about perfection. When such a perspective is promoted, the human easily becomes posthuman with no regrets or mourning. On the other hand, human-technology interactions can also be seen as representing an "artificial invasion" (Duelli Klein 1985, 6) or "technological supremacy" (Donum Vitae 1987), and as leading to dehumanisation. Those who come up with such assessments do not want to say goodbye to the human, as the price for the 'loss of the human' is believed to be very high. Similarly, the possible fall and abandonment of the body is not accepted with ease. It makes some academics such as Balsamo (1996) or Sobchack (1995) rather angry and puts them on 'body-rescue expeditions'. In their counterpolemic, the body becomes

1 Different scholars have been deeply engaged in debates on techno-human relationships, and among them some feminists. To mention only a few: Rosi Braidotti, Anne Balsamo, Donna Haraway, Katherine Hayles, Vivian Sobchack, Mike Featherstone and Roger Burrows. 
described as the inevitable materiality, the grounding reality, the memento mori and the sine qua non of one's existence. Although technology is not entirely condemned and rejected, the body is granted a superior status.

To leave behind such binary oppositions of either euphoria or melancholia, I believe there is a need for new concepts regarding human-technology interactions. Within the deleuzean framework that I advocate, such concepts should be positive and affirmative by which I mean that they should stand for an expression of abilities and becoming, but at the same time should set limits to both technology and the human body. In my view, abilities and limits add to the empowerment of the human body, and can thus be useful for a proper navigation in the present techno-world that humans are immersed in.

Human-technology interactions do not only take place in medical centres every day, but are also ubiquitously represented in contemporary visual culture. Visual representations play a significant role in establishing concepts of various important issues and phenomena (Van Dijck 2005, Franklin 2000). In this article I will explore if visual representations of human-technology encounters in medical landscapes can open doors to affirmative and positive concepts of those encounters as well as of the human body and of the 'human' per se. At the same time, I will investigate the potential of the modes of convergence that occur between visual culture and science. In order to meet these objectives, this article focuses on the particular human-technology interactions referred to as in vitro fertilization' (IVF) and its visual representations proliferating and circulating on the Internet. Firstly, based on empirical data from interviews with IVF-patients, I will present what occurs between participating bodies and technology when IVF is applied. ${ }^{2}$ Secondly, I will examine what appears to occur in IVF procedure when these human-technology interactions get visually represented on the Internet. ${ }^{3}$ Thirdly, inspired by Deleuze and Guattari, I will investigate what positive and affirmative concepts of human-technology encounters are possible and how they renegotiate our understanding of the human body and of the human being.

2 The data have been gathered from in-depth interviews conducted in 2005 and 2006 with twenty-six Polish and Dutch heterosexual couples. For lack of space I do not refer here to the interviews in great detail; see Just 2008 for the empirical data.

3 Nowadays, Internet is treated and used as one of the major suppliers of many kinds of information and as the site of public debates. On countless numbers of websites human assisted reproduction is explained and the assistance itself visually represented. Those representations are usually short movies or various photographic images. As the latter are the most common, I chose them for my analysis. 


\section{The IVF Scenario in Medical Wards}

Nowadays, hospitals, private clinics and medical centres represent territories that are crowded with various available techniques, methods and treatments. These are applied in order to measure, check, diagnose and possibly fix the body of the human subject. Every technique and every method has a particular toolbox to do so. The presence of technology is visible, audible and tangible, and, though it may sound like an exaggeration, it even has its own particular scent. In short, medical centres form technological landscapes that are highly populated with non-human actors. Undoubtedly, the medical territory, enclosed in various buildings scattered all over the world, is not just a place of pills, liquids and persistently operating machines. Contemporary medicine is also a space where human existence can easily be traced and where various techniques become practices with widely opened toolboxes. In addition, medical staff forms an intrinsic part of the present medical institutions. To complete the picture, one must include those for whom the institutions have been created in the first place: the patients. The medical centres are thus territories where both human and non-human actors simultaneously coexist and interact.

The first tools used from the IVF toolbox are the hormones that the female participant is injected with. The hormones are supposed to first suppress the natural cycle and then stimulate the growth and development of more than one egg cell (see for a critical analysis, Roberts 2008). In order to observe the maturation of the follicles, the female participant must remain under constant observation and have blood tests and ultrasound scans done. The moment the doctor decides that the size and number of egg cells are satisfactory they must be removed from the woman's ovaries. The aspiration is done with a needle, which the doctor inserts into the vagina with the guidance of ultrasound. The liquid removed from the ovaries is put into a test tube and sent to the laboratory where sperm is mixed with (classic IVF) or inserted in (IVF-ICSI) the egg cells. Embryos that possibly develop from the fertilized eggs are placed by a medical practitioner into the uterus through the cervix with the help of a plastic catheter.

From my interviews with patients it has become clear that in the practice of IVF, various elements are brought together in human-technology encounters. Technologies with their tool boxes, medical staff, female and male bodies constantly connect, interact and affect one another. The female body feels the needle going through her skin into the vein to fill the syringe with blood for hormonal analysis, senses the gel spread over her abdomen to facilitate the ultrasound scans, perceives the tool pricking the ovaries and transferring the embryos, hears the voice of a doctor or feels the touch of a nurse. The technology (needle, gel or plastic catheter) and the medical staff (the audible vibrations of the doctor's voice or the tangible warmth of the nurse's touch) literally become part 
of the female body. These sensations are followed by a wide range of various affects. I take affect here in the Deleuzean sense: "Affects are (...) nonhuman becomings of man (...)" (Deleuze and Guattari 1994, 169). As Colman explains: "Affect is the change or variation that occurs when bodies collide, or come into contact. As a body, affect is the knowable product of an encounter (...)" (Colman $2005,11)$. In a Deleuzean vein, we could say that the different machines, metallike shapes, plastic-like configurations, tubes, liquids, pills, doctors, nurses, technicians and female bodies start making alliances and producing linkages. Drawing information from the interviews, it appears that all these actors connect and affect one another.

As the female body experiences various sensations, pain, discomfort, happiness, joy or sadness, the encounter of the human body with the medical staff and technology produces affects. Depending on the success or failure of the intervention, the types of affect are never easily anticipated. These affects may get transformed into various actions of that body, for example talking with doctors, looking for advice among friends, or on the contrary, refusing treatment or making 'reproductive' jokes. I propose to understand these reactions in terms of potentia and potestas. Potentia is an active power that "maximises its potential, pushes itself to its limit and affirms the life of which it is but one expression" (Colebrook 2005, 216). Power understood as potentia allows life to expand. It is a positive force as it enables the embodied subject to act; it increases its abilities to be, to live. It is about affirmation and empowerment. Potestas is a reactive power that "turns back upon itself" (Colebrook 2005, 216). Potestas frames life. It decreases the embodied subject's possibilities of acting, being and living in affirmative and empowering ways.

To come back then to the reactions of the women who underwent IVF, some can be understood as potentia (e. g. joy or happiness) and other as potestas (e.g. despair, stagnation or withdrawal). From my interviews it has become clear that not only the patient's bodies are affected, but also those of the medical staff. This may result in particular reactions towards patients (e.g. empathy, support or advice) or have influence on the way in which the technology is applied (e. g. use of anaesthesia during egg cells aspiration or not). In any case, my point here is that neither the body nor the subject, whether patient or medical staff, remains mute and passive.

If we look further, we find that in the human-technology interaction of the IVF technique, the tool box, the medical staff putting it into practice, and the participants of female and male bodies, are not separate entities. In fact, it seems that their borders become mutually penetrable and they appear to be affirmatively dissolving into one another. This becomes clear if we realise that in IVF the female body becomes enriched with new organs assisted by technology. The ovaries produce egg cells, but only in a duet with hormones. The fallopian tubes 
allow 'eggs out', though only in joined cooperation with an aspiration needle. The uterus hosts embryos, but only after the encounter with a plastic catheter. Interestingly enough, in IVF practice the hormones do not always stimulate ovaries; connections between female and male corporeal fragments do not always result in fertilisation; and the transferred embryos do not always grow and develop. The body has its particular, sometimes incomprehensible, ways of negotiating technology. While the body interacts with technology on many levels, it expresses its potentia by preserving its organic unity, complexity and singular capabilities.

From my analysis of the data that I collected through interviews, I conclude that every human-technology encounter is about production; the body, technology and medical staff produce together through their interaction. The products are physical entities like cells, eggs, and embryos, but also immaterial ones such as sensations and affects. The final outcome of this production cannot be anticipated with certainty nor can it be established a priori as positive or negative. However, I do want to conclude here - perhaps optimistically - that in the practice of IVF all participating elements in the human-technology interactions are of equal importance with no hierarchy implied between them.

\section{Visual Representations of the IVF Scenario}

Let me now move on to the visual representations of IVF on Internet, which usually consist of three types of images. Firstly, the most common images, those of the interior design of infertility clinics. The images represent cabinets in which the observation of stimulated ovaries and retrieval of egg cells take place; the laboratories with microscopes, plastic dishes with collected genetic material, controlled rate freezers, straws to freeze embryos in, and storage tanks for sperm and embryos; and the rooms where fertilisation is performed with the help of highly sophisticated machines. Often, such images show medical staff at work, operating various apparatuses, controlling their application, checking the progress, and monitoring the whole process. Secondly, images on the internet show the human's bodily interior: dark and greyish shadows of ovaries; black and white balloon-like stains of egg cells; grey dots of spermatozoids in different shapes and sizes with long, winding lines behind them. These dots and stains are sometimes accompanied by the thin or thick black-or-white lines of visualised medical tools. Thirdly, there are Internet images of clover-like, Mickey-Mouseface-like and antic-clepsydras-likes embryos.

In visual representations of IVF, technology and the human body generally remain on two different sides of the barricade. Technology, with its quite heavily packed tool box, is omnipresent vis-à-vis the human body. It is everywhere, 
significantly filling up space, spreading over an indefinite number of rooms, and getting into the smallest and most intimate components of the human body. Technology seems to have its own identity of plastic, metal and other unknown materials, which remains ontologically different in the encounter with a human body. It stands for the 'other', separated from the carbon and water based existence of a human. While it does not operate by itself but is put into motion by medical staff, technology acquires its own adequate and accurate logic. At the same time, the medical staff appears to actually form a part of the toolbox. It is as if technology and medical staff belong to the same tool box, functioning as one actor on the body of a patient.

Visually, the human-technology interactions are about separate entities coming into contact and preserving their identities when the encounter occurs. In the images, the interactions between a patient and technology are reduced to the level of small, corporeal components. The body of a patient becomes fragmented and reduced to its reproductive bits and pieces. The body thus loses its organic unity together with its complexity and particular capabilities. There is no visual sign of the human body feeling, acting and interacting with and being affected by its environment. The effect of such visual representations is that technology, tightly coupled with the medical staff, seems not only to be omnipresent but also omnipotent. It is represented as a tool box that can act precisely, solve problems, offer solutions and deliver desired results. At the same time, the images show the human body, or rather its fragments, as in need of enhancement. The human body, together with its corporeal bits and pieces, is represented as mute and passive, speechlessly forming a surface for experimentation and improvement with no resistance or power of its own. All we see is a limited number of cells and tissues that have at best a very narrow margin for negotiation. The body appears not to participate actively in anything, but dissolves into invisibility under the law of potestas.

The images on the Internet thus seem to suggest that technology, forming a unity with medical staff, can prolong the existence of human species almost by itself. The generation, and even creation, of life is brought into the technological sphere. In visual representations of IVF human-technology interactions, then, the body and technology do not interact on the same level, in contrast to my findings in the interviews with the patients. From my analysis of the images, it follows that there is a hierarchy implied with technology on top, in line with the dominant logic of western culture that I mentioned in the introduction. 


\section{Bodies Meeting Technology; or Technology Meeting Bodies}

In this paragraph I want to theoretically reflect on the visual representation of IVF, before returning to the actual practice of IVF in the next paragraph. The scholars who have been deeply engaged in debates on techno-human relationships, generally assume a fusion between the human body and technology, for example in the figure of the cyborg (Haraway 1991). Rosi Braidotti writes that "The merger of the human with the technological, or the machine-like (...) results in a new compound, a new kind of unity (...) [which] is neither holistic fusion nor Christian transcendence - it rather marks the highlight of radical immanence" (2002, 225). By radical immanence Braidotti means "the field of forces, a quantity of speed and intensity" $(2006,126)$.

However, the human-technology interactions of IVF as they come across in visual representations do not easily allow approaching the phenomenon in terms other than these of radical ontological difference. The IVF technique with its tool box and medical staff on the one hand and human corporeality on the other hand can only be conceptualised as separate entities. They may brush and stroke each other, but their borders remain impenetrable. Even when interaction occurs, the wholeness and prescribed identity of all the parties involved remain unchanged and untouched. The mutual encounters may be understood as an event where things, differentiating in matter, meet and yet remain bordered. The human body and medical technology stay separate, discrete and tightly enveloped in their obvious distinctions. They do certainly interact, yet they maintain their separateness. Even if the human body and technology are brought together, their clearly defined and drawn borders protect them from creating a space of variable difference and production of positive and affirmative affects. The interactions can therefore not be defined as productive negotiations and transformations.

I would therefore argue that the concept of human-technology interactions as emerges from visual representations of IVF, inevitably sets forth the idea of ontological difference, binary oppositions and a lack of external influences. It thus creates an either-or relationship, in which either the technology or the body is going to be defined as superior vis-à-vis the unconquerable otherness of the 'other'. Clearly, the technological 'other' appears to be in a more superior position. The steel, the metal, the plastic, do not have a conscience or sentience and remain immune to that which the organic, carbon and water based entity is not. This implies that in the IVF procedure, the body can but be understood in terms of a burden and failure, an imperfect and dysfunctional relic in need of repair. The repair, of course, will almost certainly take place. As a result, technology can be defined either as an enhancement, a promise and saviour or as an invasion, destruction or intruder.

In my view, this binary opposition of ontological difference prevents the 
recognition of the capabilities of both technology and the human body in their mutual encounters. We also need to consider the important influence of the surrounding environment on human-technology interactions. The ontological difference, the invincible distinctiveness of bordered identities, and the lack of external influences do not allow for a conceptualisation of the human body as connective, external, affective and able to experience metamorphoses. In these images, the human body seems to be unable to affirmatively interact, get affected and become-together with its surrounding reality. It does not appear to become what Braidotti calls an "eco-logical entity" (2006, 182), where it constantly connects with its environment. In this scenario, the result of the human-technology interactions is predictable: the organic tissues, the living material, will probably surrender when faced with the alien components of technology.

From my analysis of the images of IVF on the Internet, it follows that technology and the human body are always approached as two ontologically different, and radically opposite units, repeating the binary oppositions that are so prevalent in western culture. While the human is certainly posthuman in its becoming open to technological mediation and presence within the carbonwater-based landscapes of the body, this posthuman condition carries the message that, at present, the human can only survive when coupled with omnipotent and infallible technology. The problem here, in my view, lies in the fact that the posthuman being cannot become-together with technology, but it can only become because of technology. That is why in the following paragraph I attempt to leave behind such binary oppositions of body and technology, and look for new concepts for understanding and redefining human-technology interactions.

\section{The Space of Becoming}

Let us try a completely different angle to human-technology interactions like IVF. It is high time to stop conceptualising the human body and technology as ontologically different and to stop seeing the techno-human interactions in terms of binary oppositions. Perhaps it can be difficult to accept the erasure of ontological differences, but, as Braidotti emphasises, "postmodernity is the historical time when such ontological distinctions collapse (...)" (2002, 225). She also stresses that:

The cyborg (...) breaks down the dualistic barriers between the body and its technological and technical supports (...) The cyborg functions rather as a counterparadigm for the bodily intersection with external reality; it is an adequate reading 
not only of the body, not only of machines but rather of what goes in between them (Braidotti 1994, 108).

My question then is whether the encounters between the human body and technology in the practice of IVF can be approached as the emergence of the changeable plenitude of difference and as a space of becoming. Let me explain what I mean. Becoming is a term from Deleuze \& Guattari:

Becoming is neither an imitation nor an experienced sympathy, nor even an imaginary identification. It is not resemblance. Rather becoming is an extreme contiguity within coupling of two sensations without resemblance or, on the contrary in the distance of a light that captures both of them in a single reflection (...) It is the zone of indetermination, of indiscernibility, as if things, beasts and persons (...) endlessly reach that point that immediately precedes their natural differentiation $(1994,173)$.

Becoming, then, in the context of my topic is an affirmative process of transformation that links the different actors in human-technology encounters.

In IVF practice different machines, tubes, liquids, pills, patients, doctors, nurses, technicians, female and male bodies start connecting, make alliances and produce linkages. It is a process of becoming-together that allows for differences to exist, defying an ontological difference of binary oppositions. As Grosz argues, in referring to Deleuze:

Subject and object are series of flows, energies, movements, strata, segments, organs, intensities-fragments capable of being linked together or severed in potentially infinite ways other than those which congeal them into identities. Production consists of those processes which create linkages between fragments, fragments of bodies and fragments of objects $(1994,167)$.

As I have argued above in my analysis of IVF practices, the shapes and borders of participating actors become blurry if not in fact partially effaced. There are no more separate entities with their own distinct identities, but a "zone of indetermination" and "a new compound, a new kind of unity" (Braidotti 1994, 225). Without ontological distinctions and binary oppositions, the space of becoming opens up.

The space of becoming that gets created is about affects and flows, containing various intensities. It is usually enriched by the presence of other humans significantly adding to and influencing the kind of becomings that follow the human-techno encounters. To look at the human-techno interaction as the emergence of a space of the variable multitude of difference, means that the hierarchy of the actors involved can no longer be valid. With no borders between 
blurring identities, ontological difference collapses. Thus, in this postmodern tango, technology can no longer claim priority or superiority and we should leave behind words like 'artificial invasion' or 'technological supremacy' that I quoted in the introduction. At the same time, it is important not to fall into the trap of reversing the binary opposition and give the body any status of superiority. In this sense, a logic that wants to establish which of the two, body or technology, is superior or inferior lacks any sense. The point here is that in the space of becoming ontological distinctions are erased and binary oppositions are transgressed.

The next step in creating new concepts regarding human-technology interactions is to ascertain whether such a space of becoming is negative or positive. Of course, the final outcome of the interactions, thus the probability of positivity or negativity, can never be a priori anticipated. The criterion of positivity here is affirmation in the sense of potentia; that is to say what makes the encounter possible. If one's power to act is increased and if one's action does not block the flows and the intensities of the others, then the interaction can be described as positive. The new conceptualisation of the human-techno encounter as a space of productive becoming indicates the connective, external and affective nature of the human body. As the human body remains in constant interaction with its surrounding reality, it gets affected by various sensations of experiencing the non-human becoming, in this case of technology and of medical landscapes (Deleuze and Guattari 1994, 169). We could say that in the case of IVF practice the body is in ceaseless processes of transformations and metamorphoses.

As we have seen, the contemporary landscapes of medicine are crowded with various human and non-human actors. Countless medical centres and wards intrinsic to those landscapes bring the actors together in order to launch desired interactions and to eventually reach the hoped for conclusions and achievements. Medical procedures invite the various actors of technology and human bodies for a full participation. As I mentioned above, the many different actors in IVF-practice connect, ally and link up, blurring the boundaries between them. This is not to say that these actors-participants lose their agency or particular singularity. Rather, it indicates the becoming-like and process-like characteristics of the human body and technology alike. It emphasises that any encounter is in fact about metamorphosis, consisting of affects, flows and intensities.

The specificity of the human-technology interactions works as an indication and, at the same time, a confirmation of the fact that the human body is external and affective, prone to transformations and experiences of non-human becomings. What it will become, what kind of further production it will be capable of, is not always easy to predict. As Braidotti writes: 
Being environmentally bound and territorially based, an embodied entity feeds upon, incorporates and transforms its (natural, social, human, or technological) environment constantly. Being embodied in this high-tech ecological manner means being immersed in fields of constant flows and transformations. Not all of them are positive, of course, although in such a dynamic system this cannot be known or judged a priori (Braidotti 2006, 41).

This very fact of unpredictability regarding what the encounters will lead to, of what the human body will be able to do, makes the techno-human interactions be about experiment and possibility rather than danger and stagnation. The carbon and water based entities do have limits, yet in the process of becoming they may produce various forms or turn into positive shapes that increase their potential to act and to be - or rather to become. This can then be understood in terms of mutual negotiations, becoming-together and productive cooperation, rather than in terms of defeat or surrender. Thus, there is a certain egalitarianism and lack of hierarchy that allows for "the provisional linkages of elements, fragments, flows of disparate status and substance: ideas, things-human, animate, and inanimate (. . .)" (Grosz 1994, 167).

If human-technology interactions can be conceptualized in terms of becoming where separate entities become one another, lose their distinct identities and reach the level of 'indetermination' and 'indiscernibility', the concept of the human can be redefined in terms of "inhuman" in the Deleuzean sense: "In truth, there are only inhumanities, humans are made exclusively of inhumanities, but very different ones, of very different natures and speeds" (Deleuze and Guattari 1987, 190). Although the term may be confusing at first sight, to understand the human body in its interaction with technology as a form of inhumanity, allows for an understanding of the affirmative abilities of any human being to link with, embrace and become together with its surrounding technological environment.

\section{Conclusion}

In this article, I have first examined human-technology encounters in the practice of IVF based on empirical data from interviews with IVF-patients, on the basis of which I forwarded the idea that every human-technology encounter is about creative and interactive production. Also, I suggested that - contrary to the western logic of ontological difference and binary oppositions - all participating elements in the human-technology interactions in the actual practice of IVF are of equal importance with no hierarchy implied between them.

I then proceeded to look at visual representations of IVF procedures on the 
Internet. Here I argued that in the images on the Internet the body and technology do not interact on the same level, confirming a hierarchical position for technology over the human body. In visual culture, then, the human body and technology are approached as two ontologically different, and radically opposite units, repeating the binary oppositions that are so prevalent in western culture.

In the third part of my article, I have attempted to leave behind such binary oppositions of body and technology, by investigating new, positive and affirmative, concepts of human-technology encounters. Here, I used a Deleuzean framework to understand the human-technological encounter as an affirmative space of becoming where transformations and metamorphoses are possible, and where ontological distinctions are erased and binary oppositions are transgressed.

As visual representations of the encounters between the human body and technology fail to establish affirmative concepts of such interactions, I conclude that the potential of the modes of convergence that have occurred between visual culture and science cannot be assessed as positive. However, it must be kept in mind that only one form of medical practice (IVF) and one form of visual representation (images on Internet) have been addressed in this article. To definitively assess the potential of convergence between visual culture and science, analysis of more and different medical procedures and its visual representations is necessary. Furthermore, it is important to realise that affirmative visual representations of IVF scenarios are possible. To properly use the positive potential of the visual culture and science 'combo' is crucial, if we want to abandon the over-familiar rhetoric of ontological difference and binary oppositions between the human body and medical technology.

In a Deleuzean approach to IVF-practice, I hope to have shown that it is possible to conceptualise human-technology interactions differently, i. e. affirmatively. This allows for an approach of human-technology encounters in terms of productive cooperation, rather than in terms of defeat or surrender. To understand such cooperation as affirmative and productive, or in other words, as a space of transformative becoming, enables us to see that the interaction between the human body and its technological surrounding can be one of experiment and possibility rather than danger and stagnation. Thus, we can leave behind the euphoria or melancholia of binary oppositions and instead engage with an empowered view of the human body in its affirmative relation to technology. We can then properly navigate in the present techno-world that we inhabit. 


\section{Bibliography}

Braidotti, R. 1994. Nomadic Subjects. New York: Columbia University Press.

Braidotti, R. 2002. Metamorphoses. Towards a Materialist Theory of Becoming. Cambridge: Polity Press.

Braidotti, R. 2006. Transpositions. On Nomadic Ethics. Cambridge: Polity Press.

Balsamo, A. 1996. Technologies of the Gendered Body. Durham and London: Duke University Press.

Colebrook, C. 2005. Power. In The Deleuze Dictionary, ed. A. Parr. Edinburgh: Edinburgh University Press.

Colman, F.J. 2005. Affect. In The Deleuze Dictionary, ed. A. Parr. Edinburgh: Edinburgh University Press, 2005.

Deleuze, G. and F. Guattari. 1987. Thousands Plateaus, Capitalism and Schizophrenia. London and New York: Continuum.

Deleuze, G. and F. Guattari. 1994. What is Philosophy? New York: Columbia University Press.

Deleuze, G. 2001. Pure Immanence. Essays on A Life. New York: Zone Books.

Donum Vitae: Instruction on Respect for Human Life in its Origin and on the Dignity of Procreation Replies to Certain Questions of the Day. Congregation for the Doctrine of the Faith, Rome, February 22, 1987.

Duelli Klein, R. 1985. What's 'New' about 'New' Reproductive Technologies. In Man-Made Women. How New Reproductive Technologies Affect Women, ed. G. Corea. London: Hutchinson.

Featherstone, M. and R. Burrows. 1995. Cyberspace/Cyberbodies/Cyberpunk. Cultures of Technological Embodiment. London: SAGE.

Franklin, S., C. Lury, and J. Stacey. 2000. Global Nature, Global Culture. London: Thousand Oaks, New Delhi: Sage.

Grosz, E. 1994. Volatile Bodies. Toward a Corporeal Feminism. Bloomington, Indianapolis: Indiana University Press.

Haraway, D. 1991. Simians, Cyborgs and Women: The Reinvention of Nature. New York: Routledge.

Just, E. 2008. New Reproductive Assemblages: Understanding, Managing and 'Using' Human In Vitro Fertilization (IVF). Unpublished Doctoral Thesis. Utrecht University.

Roberts, C. 2008. Fluid Ecologies.Changing Hormonal Systems of Embodied Difference. In Bits of Life. Feminism at the Intersections of Media, Bioscience, and Technology, eds. A. Smelik and N. Lykke, $45-60$. Seattle: Washington University Press.

Sobchack, V. 1995. Carnal Thought: Embodiment and Moving Image Culture. Berkeley: University of California Press.

Van Dijck, J. 2005. Transparent Bodies. A Cultural Analysis of Medical Imaging. Seattle: University of Washington Press. 
Open-Access-Publikation im Sinne der CC-Lizenz BY-NC-ND 4.0 (C) 2010, V\&R unipress GmbH, Göttingen 


\section{Part III: Bioart}

Open-Access-Publikation im Sinne der CC-Lizenz BY-NC-ND 4.0

(c) 2010, V\&R unipress $\mathrm{GmbH}$, Göttingen 
Open-Access-Publikation im Sinne der CC-Lizenz BY-NC-ND 4.0 (C) 2010, V\&R unipress GmbH, Göttingen 


\section{Chapter 9: Our Cells/Our Selves: Sexual Politics in Bioart}

\section{Introduction}

The artist and the scientist have increasingly come to inhabit contiguous or overlapping aesthetic and epistemological spaces. As Andrea Duncan remarks, many works of contemporary art, in particular bio-art, slip "from a neutral dialogue with the scientific into the metaphysical, provoking fundamental questions about the nature of identity, and, ultimately, of being" (2000, 144). My purpose in this essay is to look at selected artworks by two artists, Helen Chadwick and Julia Reodica, who, through the use of their own cells which are made to grow and interact with other materials in particular ways, offer a pointed commentary on the sexual politics attached to specific parts of the female body, such as the hymen and the placenta. I will consider Helen Chadwick's One Flesh (1985) and Viral Landscapes (1988-89), as well as Julia Reodica's The hymNext Project (2005) as examples of art that interfaces with the body, making the latter's cells, viruses and DNA the object and vehicle of artistic practice as well as social intervention and critique. Indeed, by focusing on the physical and cultural functions of the hymen and the placenta, these artists call attention to the ways in which these organs have been made complicit with male domination. In these works they also investigate issues of identity by exploring the nature of individuality, inextricably linked to the cells which are shown to be inescapably our selves. Issues of visibility and invisibility are thus central in the works I will be analysing here. There are two main foci in this essay: the turn inwards of versions of self-portraiture, which emphasize the genetic decoding of one's genome; and the visibility conferred on the hymen and the placenta, female organs or membranes that function as thresholds. 


\section{Viral Aesthetics}

Helen Chadwick's Viral Landscapes (1988 - 9) consist of five photographs of the coast of Pembrokeshire in Wales, each of them three metres wide, overlaid by computer-enhanced images of her own cells. In Viral Landscapes cells from her cervix, vagina, ear and mouth are superimposed on other sources, such as paint and sea water in multi-layered compositions. Chadwick herself described Viral Landscapes as a "vital relation of incompatible elements co-existing in gentle friction (...) the between of nature - patterns of desire in symbiosis" (2004). According to Chadwick, her Viral Landscapes should be regarded as "territories of a prolific encounter, the exchange of living and informational systems at the shoreline of culture", a symbiotic encounter that Chadwick sees as emancipatory since it abolishes unyielding boundaries $(1989,97)$. Indeed, the layering of the landscape shots with the photographs of scrapings from her own cells hints at the interconnectedness of self and world, at the porosity of bodily boundaries. It also reminds us of the context of fear of disease, specifically of HIV and other viruses, of widespread concern at the time they were made. As Chadwick comments, "we have become a viral condition in the landscape" (in Kent 1990, 32). Her cells are unavoidably her/self, her work becomes her cells/self in an embodied practice which she regards as evoking the permeable, porous boundaries between her body and the natural world, as well as other bodies. Chadwick describes photography, a technique used in her Viral Landscapes, as nothing less than "my skin" $(1989,109)$, as a "membrane separating this form from that", fixing the "point between, establishing my limit, the envelope in which I am. My skin is image, surface, medium of recognition" (109), a "permeable screen" (109), and, in terms relevant to Viral Landscapes, she comments that "inside is outside is inside" (109).

Chadwick describes her Viral Landscapes with recourse to a semantic register that repeatedly emphasizes borders, envelopes, membranes, inside/outside, ideologies of domination. Musing on the abolition of boundaries and dogmatic dualisms, departing from the cell all the way to complex systems, Chadwick ponders the dynamics of this process of viral infection:

The last vestige of autonomy is the self-sufficiency of the cell, separated from all around by that first boundary, the protoplasmic envelope. It is the original frame. But it will yield to the impetus of a virus and surrender its sovereignty. In return a process begins. On the threshold of living, the virus highjacks the replication material of the cell to effect its continued proliferation (Chadwick 1989, 95).

Chadwick's 'viral aesthetics' $(1989,97)$ thus rehearse a productive encounter which stresses rhizomatic becomings, to use Deleuze and Guattari's terms 
(1992), emphasizing the potential for interaction and unexpected, non-hierarchical connections. As Chadwick elucidates:

At its most intimate, the abolition of frontiers renders my body up as cells and tissue, vulnerable to manifold incursions. Released from the bonds of form and gender, flesh is volatile and free to wander in an aetiology of complete abandon. (...) The living integrates with other in an infinite continuity of matter, and welcomes difference not as damage but potential (Chadwick 1989, 97).

Chadwick is tentatively looking for an alternate concept of the self that does not depend on static, inflexible borders, but that is more in tune with the deep-seated symbiotic affinities underlying all the beings in the world and their environment. If on the one hand the penetration of membranes and bodily barriers leaves one open to the invasion of harmful bacteria and viruses, on the other hand, despite concerns about contagion, our age is predicated precisely on the abolition of borders, on the obliteration of imperialism. According to Donna Haraway, life is a "window of vulnerability" (1991, 224), while the "perfection of the fully defended, 'victorious' self is a chilling fantasy (...) whether located in the abstract spaces of national discourse, or in the equally abstract spaces of our interior bodies" (224), a scenario Chadwick seems to illustrate in her Viral Landscapes. Chadwick's aim was to "create an image of simultaneous penetration, of the sea and the body" $(2005,19)$, which she describes as "disturbing, but also a possibility, a new shift in the relation of things that could offer some expanding potential" (19), clear of boundaries and borders, beyond the skin, in keeping with the symbiotic matrix of our surrounding world.

\section{Placental Poetics}

In One Flesh (1985), loosely based on a Van Eyck-like Madonna and Child, Chadwick engages with and subverts entrenched, traditional images and symbols. In this case she draws on the Virgin Mary, depicted with unconventional visual representations, with the irruption of unexpected, feminine symbols, including the placenta, which can be seen as a pertinent example of Chadwick's disruption of the then still dominant male gaze. Both One Flesh and Reodica's The hymnNext Project confer added visibility to the placenta and the hymen, female organs usually hidden inside the body and playing somewhat ambiguous roles.

Chadwick's One Flesh represents a Madonna and Child, with a number of transgressive differences from the traditional iconic religious renditions. In Chadwick's work, Jesus is replaced by a female baby, an aspect made abundantly 
apparent through the Madonna's deliberate pointing to the baby's labia, in a boldly transgressive move. Another meaningful subversion has to do with the Madonna's halo, which in this case is substituted by a gilded placenta. Chadwick's acknowledged aim was to "subvert [the] docile domestic image" (in McKellar 2007, 264). ${ }^{1}$

One Flesh (1985), although a very modern rendition of a Madonna and Child, is however clearly inscribed in a long iconographic tradition of representation of the Virgin and Child even as it subverts it, recalling in its shape and colouring an altarpiece. One Flesh calls insistently attention to the physical aspects of birth, the placenta figuring as a profane halo, the hanging umbilical cord which has just been cut by the mother, who is still holding the scissors, severing the visceral connection between mother and child. Chadwick's One Flesh, where the Madonna's halo has been substituted by a placenta, can also be inscribed in a line of continuity with Max Ernst's mildly sacrilegious painting The Virgin Spanking the Infant Jesus with Three Beholders (1926). In the latter, a strongly-built Virgin Mary dressed in a tight, bright red dress, not the blue mantel usually associated with the Virgin, is portrayed beating the infant Jesus, astride on her knees. Apart from the fact that this is not an iconographically traditional representation of Madonna and Child, Jesus's halo is lying on the floor, a desecratory, irreverent, impious, provocative gesture.

Chadwick herself describes the placenta, with a part of the umbilical cord still attached to it, as an "uncanny object", a "somatic and profane halo" which forms a kind of "biological trinity" jointly with mother and baby (unpublished interview with Mark Haworth-Booth; see Herles 1997). In addition, the Madonna's robe, instead of the traditional blue associated with the Virgin Mary, is bright red, while at the very top of the altarpiece can be seen a drawing of a vagina, which Chadwick describes in the same interview as "pierced with jewellery" and "taking up the usual lofty position of a cherub or perhaps an allegorical sun and moon", thus stressing, even though with recourse to subversive imagery, her work's inscription in a long tradition of religious artistic iconography.

Luce Irigaray's examination of and development of new readings of the feminine morphology might hold new, positive connotations for a number of organs that, like the womb, the placenta or the hymen, have tended to be burdened with conflicting symbolism and interpretations. In words that can offer an apt commentary on Chadwick's placental halo in One Flesh Irigaray wonders how the "relationship with the placenta, the first house to surround us, whose halo we carry with us everywhere, like some child's security blanket, (...) is represented in our culture" $(1991,40)$, and she concludes that there really is no

1 Chadwick's annotations to her copy of Marina Warner's Alone of All Her Sex: The Myth and Cult of the Virgin Mary (1976). See Leila McKellar 2007, 264. 
representation of it. The placenta can be seen as occupying an in-between position, this time between the embryo and the mother, to some extent like the ambiguous location of the hymen, at a bodily threshold. Indeed, for Irigaray, the placental economy would be predicated on mediation, not fusion, since the placenta, as a formation of the embryo and made up of egg and sperm cells, fosters transference between mother and child, keeping their difference, an aspect validated by medical science. ${ }^{2}$ Biologist Hélène Rouch, interviewed by Irigaray, explains what the placenta is as well as its functions:

It's a tissue, formed by the embryo, which, while being closely imbricated with the uterine mucosa remains separate from it. This has to be reiterated, because there's a commonly held view that the placenta is a mixed formation, half-maternal, halffetal. However, although the placenta is a formation of the embryo, it behaves like an organ that is practically independent of it (Irigaray 1993, 38-39).

Furthermore, as Rouch elucidates, the placenta "plays a mediating role on two levels. On the one hand, it's the mediating space between mother and foetus, which means that there's never a fusion of maternal and embryonic tissues. On the other hand, it constitutes a system regulating the exchanges (...) but also modifying the maternal metabolism" (Irigaray 1993, 39). Irigaray's discussion of a placental economy, where prominence and a greater visibility is conferred on the placenta, contributes, like Chadwick's One Flesh, to the reappraisal of the cultural and medical roles played by this ephemeral organ, which tends to be mostly unseen and unrepresented.

In an analogous vein, Bracha L. Ettinger's revisionary readings of Freud and Lacan can be fruitfully applied to the works I am analysing here, which can all be seen as part of a larger reinscription of feminine sexuality and its symbols in the cultural and scientific imaginary. Chadwick's One Flesh signals a change in the gendered economy of the dominant androcentric episteme by evoking a "matrixial Gaze" to use Ettinger's term $(2006,41)$, Ettinger also suggesting that we go "beyond criticism and deconstruction of the phallic gaze, to elucidate another gaze at the horizon of the aesthetic experience" (1999). According to Ettinger, the matrix (from matrice, womb) is:

modelled upon certain dimensions of the prenatal state which are culturally foreclosed, occluded, or repressed. It corresponds to a feminine dimension of the symbolic order dealing with asymmetrical, plural, and fragmented subjects composed of the known as well as the not-rejected and not-assimilated unknown, and to unconscious processes of change and transgression in borderlines, limits, and

2 For a further discussion of the placenta and the maternal-fetal relation see Kelly Oliver 1997. 
thresholds of "I" and "not-l" emerging in co-existence (Ettinger 1992, 176, emphasis mine).

Ettinger considers that this matrixial borderline space can be perceived alongside the phallic dimension, thus allowing for the emergence of a female desiring subject. Indeed, Chadwick's heretical Madonna with Child emphasizes the mother's role and desire, bringing into relief the often occluded and repressed maternal jouissance and her corporeality, a matrixial substratum and gaze, nonphallic and non-oedipal, as well as a new placental economy, borrowing Irigaray's words. According to Hillary Robinson, Irigaray makes available for us a "number of strategies, both pragmatic and philosophical" $(2006,200)$ which start from a "recognition of the limits of the present Symbolic structures" (200), a tactic which will "inevitably involve a repossessing of images and a refiguration of our sexuate subjectivity" (200), as well as a reconfiguration of the gaze in a matrixial register; a strategy that I believe is operative in all the artistic pieces looked at in this essay. In this framework, Griselda Pollock's query goes to the heart of Chadwick's practice: "What is involved in a nonphallic, matrixial reading of an artistic text?" $(1996,204)$, a question with which these artworks engage in polemical ways. Indeed, for Pollock, the matrix "reveals the sexual difference at work in our forms of knowledge, interpretation and curatorship" (1996, 81).

All the art works I analyse here seem to me to conform to this metramorphic practice of exploring thresholds and boundaries, interstitial spaces and borderlines, allowing for new perspectives to emerge and transformative practices to occur. These works are also intimately engaged with issues of liminality, of questioning thresholds, intermediate, transitional states, the in-between, the transgressive and the hybrid, in a probing investigation of spaces where the feminine can be inscribed in its own right, not instead of the phallic territory but in a contiguous terrain. As Mary Horlock asserts, the "great strength of Chadwick's art lay in how it explored the ambiguous and the in-between" $(2004,44)$.

One Flesh also implicitly draws on the notion of the (unbroken) hymen in the Virgin Mary's conception and birth of the baby Jesus, a long-standing anxiety which has strongly contributed to the subordination of women to patriarchal dictates and exploits perceptions of leaking, unclear, indistinct boundaries, a thematic area which is also addressed by Reodica's installation of designer hymens, The hymNext Project (2005). 


\section{Hymeneal Politics}

Julia Reodica is an American artist whose work interfaces between art and science. She is particularly interested in the social influence of new scientific technologies, including the ethical issues that her own art works raise, since she uses live materials, namely her own vaginal cells, which she grows in particular shapes, such as hymens, to raise awareness of the profound cross-cultural differences that apply to views of the hymen as well as the overriding impact they have on people's lives. As Reodica explains, in relation to her The hymNext Project:

My cells are part of the sculptures because I want myself to be new art media, thus 'giving myself away' to the art process. In each sculpture with my cells, my DNA is a personal signature (...). In biological and philosophical modalities, I am, like the hymen, in between the artistic and scientific disciplines. The resulting art pieces are a conjuration of new symbols to encourage discussion about scientific research and body politics (Reodica 2008, 73).

Reodica's art project of growing hymens in the laboratory environment that can then be used for medical purposes offers a pointed commentary on the sexual, cultural and political practices at work in the contemporary world, inevitably calling attention to the still deeply embedded patriarchal worldview that shapes and directs women's decisions about their hymens. Reodica's undertaking of growing the hymens outside the body to a great extent removes the ambiguity of borders, of the "in-between-ness" of this membrane, in Derrida's word (1991, 186), evoking the multiple connotations and symbolic freight that have accrued around it. ${ }^{3}$

Referring to the mediality of skin and endogenous design of tissues Nicole Karafyllis regards skin as not a "mere surface nor a physical container but instead as a hybrid of constantly rearranging natural and social orders" (2008, 43), an assertion that also prompts reference to Chadwick's Viral Landscapes. Reodica's hybrid hymens, in turn, remind us not just of the porosity and intermediality of all creatures, on account of the mixed provenance of their tissues but also, inevitably, of their in-betweenness, as thresholds in the controversial Derridean sense. In that context they can also be perceived as symbolic of the

3 Susan E. Stiritz and Britt-Marie Schiller consider that virginity is premised on "phallocentric conceptions [which] disadvantage women by mirroring back to them male desires, fantasies, and experiences rather than their own" (134). However, as they further maintain, in tune with my argument and with Reodica's installation, "what has been historically constructed can be reconstructed along new trajectories, with different possibilities and conceptions opening up" (155). 
cultural and religious barriers erected by some ideologies between women and their attainment of a state of social and legal equality with men. Reodica's installation challenges the traditional function and symbolism of virginity in a number of ways: these hymens are designed to grow and re-virginize, thus signalling their status as a commodity which can be traded and purchased. Hymenorrhaphy, or hymen reconstruction surgery, is carried out by gynaecologists in private clinics, willing to accede to the pressures placed on them by the cultural and religious traditions their clients are submitted to and surgically reconstruct their hymens. ${ }^{4}$ As Reodica herself maintains, in The hymNext Project the "celebration of the recreated hymen is emphasized - and repeatable if desired. (...) By creating hymens that are based on the remnants of traditional cultures, antiquated gender rules are disengaged, new iconographies are associated, and the symbolism once again goes into flux" $(2008,73)$.

Another fundamental aspect of Reodica's designer hymens is that they are unisex, independent of the fluctuation and instability of gender roles in society. For Reodica, the artificial replacement hymen

symbolizes the redefining of new, sexual beginnings for women and men. Treating the hymen as a replaceable object and creating a piece that implies repeated events of defloration may be abhorrent to some but celebratory to others. Women can mentally re-virginize their sexual being despite the rupture of a hymen due to an unsatisfactory sexual past or trauma. Men can re-virginize too, for the similar reasons. The hymens are intended as symbolic gifts to lover counterparts (Reodica n.d., emphasis in original).

As Reodica further elucidates: "The creative intent is to work with the skin or tissue separate from the gendered body; therefore the work process and final piece challenge or de-emphasize the idea of assigned gender. The technical research and manipulation of cells in a novel environment does not include gender at all, but purely the cell as a living, architectural being" $(2008,73)$. These artistic pieces thus vividly express the intersections and the intermedial work between art and science, focusing attention on individual organic material as the vehicle used for artistic expression as well as on the increasingly porous boundaries between our bodies, our cells/selves and other bodies and environments.

Reodica's artistic visual representations of manufactured hymens resonate with some of the vexed questions alluded to by Derrida and Irigaray in their respective readings of the hymen. In the context of his reading of Mallarmés short fiction Mimique, Derrida deploys his analysis of the hymen, which for him

4 For a detailed account of traditional rituals and perspectives on the hymen, including reconstruction, both in the West as in the Muslin and Hindu worlds, see Jelto Drench 2005. 
functions as a figure of the "undecidable" (1991, 185), of the in-between, a membrane that stands between inside and outside, suggesting simultaneously a joining and a separation, a rupture and a fusion. According to Derrida, the hymen can be inscribed alongside a semantic register that includes such concepts as mimicry, appearance, imitation, traces, all of which can be assigned to the hymen's presence or lack thereof, its remaining vestiges faint memories of the original. In the context of my discussion of Reodica's hymeneal art, the concept of copy and original, of mimicry and simulation, will be seen to shed light on the artist's installations.

For Derrida, the hymen constitutes a "presence both perceived and not perceived, at once image and model, and hence image without model, neither image nor model" $(1991,184)$. In words that recall Reodica's jewel boxes where the hymens are placed, as commodities, consumer items, maybe even trophies, Derrida refers to the hymen as "protective screen, the jewel box of virginity, (...) the fine, invisible veil which, in front of the hystera, stands between the inside and the outside of a woman" (1991, 186, first emphasis mine; second emphasis in original). While, for Derrida, the stress falls on the invisibility and inbetweenness of the hymen, Reodica, by contrast, gives it a prominent, highly visible position outside the body, removing long-held beliefs and prejudices associated with it.

As a counterpoint to Derrida's masculinist vision of the hymen, in turn, Irigaray proposes a hymeneal politics that does not consider the woman's virginity as a commodity, as exchange value among men, since it is the circulation of women among men that structures patriarchal society. For Irigaray, a woman, as a virgin, is "pure exchange value. She is nothing but the possibility, the place, the sign of relations among men. In and of herself, she does not exist: she is a simple envelope veiling what is really at stake in social exchange" $(2000,186$, emphasis in original). Referring specifically to the hymen, Irigaray observes that the

ritualized passage from woman to mother is accomplished by the violation of an envelope: the hymen, which has taken on the value of taboo, the taboo of virginity. Once deflowered, woman is relegated to the status of use value, to her entrapment in private property; she is removed from exchange among men (186, emphases in original).

Reodica brings to the fore the ambiguous nature of the hymen, as tissue and membrane that is both natural and manufactured, gift or commodity, depending on its location in the hymeneal economy of exchange value, a symbolic economy which often still turns women's bodies into objects to be exchanged and circulated amongst men. 
As a relevant counterpoint to Reodica's The hymNext Project can be cited Futurist poet and essayist Mina Loy's advocacy of the surgical elimination of virginity in pubescent girls in her daring 'Feminist Manifesto' (1914). Loy's manifesto provides a radically different perspective from the practice, alluded to by Reodica, of surgically reimplanting new hymens on women who had theirs ruptured and who wish to pass as virgins again. Loy is scornful of the value attached to women's virginity, which turns woman into a commodity, an object to be purchased by men, while also criticising the generalised passive feminine stance as far as this widespread situation is concerned, regarding marriage as a life insurance, a guarantee of personal and financial security. In her manifesto, which she considered as "an absolute resubstantiation of the feminist question" $(1997,216)$, Loy is deeply critical of the "fictitious value of woman as identified with her physical purity" (154) and argues:

the first self-enforced law for the female sex, as a protection against the man made bogey of virtue - which is the principal instrument of her subjection, would be the unconditional surgical destruction of virginity through-out the female population at puberty - (Loy 1997 154-155, emphases in the original). ${ }^{5}$

Loy goes on to reflect on man's intrinsic value as compared to woman's, dependent "entirely on chance" (155) and on her relation to a man, as well as on the sexual politics of marriage, which Loy regards as often an absurd arrangement consisting of a man's "thank offering" (155) to a woman "for her virginity" (155). In keeping with her feminist views, Loy proclaims that "there is nothing impure in sex" (156, emphasis in the original) and that the abolition of the idea that sex is impure and immoral "will constitute an incalculable \& wider social regeneration than it is possible for our generation to imagine" (156). ${ }^{6}$ Nevertheless, almost one hundred years later, Reodica still feels the need to call attention to the many ingrained and widespread inequalities attached to the hymen and its myths in today's world.

\section{Conclusion}

As I argued earlier, the drive to make visible what has traditionally been hidden, such as the placenta and the hymen, suggests the impulse to dephallicize the overriding patriarchal gaze which becomes, in terms of the works examined here, a matrixial gaze. Operating alongside a parallel axis, the urge inwards, to

5 For a literary contextualization of Loy's "Feminist manifesto" see the Introduction and notes by Roger L. Conover, especially $216-217$.

6 See also Paul Peppis, "Rewriting Sex: Mina Loy, Marie Stopes, and Sexology". 
the interior of the body and its cells, invokes novel ways of asserting individuality in a paradoxically always already symbiotic world, where borders are defused and thresholds privileged, evocative of metramorphic interactions and encounters.

In this context, then, the works by Chadwick examined here exhibit a turning inward to the body, away from external appearances, suggestive of a scientific and genetic imaginary reminiscent of a paradigm shift that took place in the last decades of the twentieth century. This cellular imaginary and poetics, which interfaces the body and the external world, since there is a constant trafficking between bodies and environment, goes to the heart of contemporary biological developments which propose that to a great extent we are defined by our DNA: we are our genetic information. Culture and the environment do, however, have some impact on the expression of those genes, an intermediality that Chadwick addresses when she uses sea water on her Viral Landscapes, as well as when Reodica grows her own cells into hymen-like structures to comment on the sexual politics of virginity.

In addition, these works can also be regarded as alternative attempts at selfportraiture, drawing as they do on the artists' cells, in an effort to reflect on the nature of identity and the increasingly permeable boundaries of the body. As Donna Haraway muses: "Why should our bodies end at the skin, or include at best other beings encapsulated by skin?" (1991, 178). Chadwick and Reodica explore precisely the space beneath the skin, the occluded interiority of bodies, bringing to light and placing in artistic contexts organic elements traditionally not seen in such configurations, which by dint of those novel frameworks and interfaces suggest new avenues of relationality in a symbiotic world.

\section{Bibliography}

Chadwick, H. 1989. Enfleshings. New York: Aperture/A New Images Book.

Chadwick, H. 1999. Re-in/de-fuse. Other Voices. 1(3) http://www.google.com/search?client $=$ safari\&rls $=$ en $\& \mathrm{q}=$ ettinger + threatens + the + phallic + narcissism,$\&$ ie $=$ UTF $8 \&$ oe $=$ UTF-8 (accessed 26 June 2009).

Chadwick, H. 2004. The Art of Helen Chadwick (DVD).

Chadwick, H. 2005. Helen Chadwick: Of Mutability, ed. N. P. James. London: CV Publications.

Deleuze, G. and F. Guattari. 1992. A Thousand Plateaus: Capitalism and Schizophrenia, trans. B. Massumi. London: The Athlone Press.

Derrida, J. 1991. The Double Session. In A Derrida Reader: Between the Blinds, ed. P. Kamuf, 171 - 99. New York and London: Harvester Wheatsheaf.

Derrida, J. 1992. The First Session. In Acts of Literature, ed. D. Attridge, 127 - 80. New York: Routledge. 
Drench, J. 2005. The Origin of the World: Science and Fiction of the Vagina, trans. A. and E. Pomerans. London: Reaktion Books.

Duncan, A. 2000. Inside - Outside - Permutation: Science and the Body in Contemporary Art. In Strange and Charmed: Science and the Contemporary Visual Arts, ed. S. Ede, 144-63. London: Calouste Gulbenkian Foundation.

Ede, S. 2005. Art and Science. London and New York: I. B. Tauris.

Ettinger, B.L. 1992. Matrix and Metramorphosis. Differences 4(3): 176-208.

Ettinger, B.L. 1993. Woman-Other-Thing: A Matrixial Touch. In Matrix-Borderlines (catalogue), ed. D. Elliott and P. Ferris, 11-8. Oxford: MOMA.

Ettinger, B.L. 1996. Metramorphic Borderlinks and Matrixial Borderspace. In Rethinking Borders, ed. J. Welchman, 125 -59. Minneapolis: University of Minnesota Press.

Ettinger, B.L. 1999. Re-in/de-fuse. Other Voices. 1(3) http://www.google.com/search?client $=$ safari\&rls $=$ en $\& \mathrm{q}=$ ettinger + threatens + the + phallic + narcissism,$\& i e=U T F-$ $8 \&$ oe $=$ UTF-8, 30/4/09.

Ettinger, B.L. 2006. The Matrixial Borderspace, ed. B. Massumi. Minneapolis and London: University of Minnesota Press.

Haraway, D. 1991. Simians, Cyborgs, and Women: The Reinvention of Nature. London: Free Association Books.

Hauser, J. 2008. Sk-Interfaces: Exploding Borders - Creating Membranes in Art, Technology and Society. Liverpool: Fact \& Liverpool University Press.

Hauser, J. 2008. Who's Afraid of the In-Between? In Sk-Interfaces: Exploding Borders Creating Membranes in Art, Technology and Society, ed. J. Hauser, 6-17. Liverpool: FACT \& Liverpool University Press.

Herles, E. 1997. Helen Chadwick: One Flesh. Exposure 2(3) http://members.lycos.co.uk/ exposuremagazine/helen.html (accessed April 24, 2009).

Horlock, M. 2004. Between a Rock and a Soft Place. In Helen Chadwick, ed. M. Sladen, 33 46. London: Barbican Art Gallery and Hatje Cantz Publishers.

Irigaray, L. 1991. The bodily encounter with the mother. In The Irigaray Reader, ed. M. Whitford, 34-6. Oxford: Basil Blackwell.

Irigaray, L. 1993. Je, tu, nous: Toward a Culture of Difference, trans. A. Martin. New York and London: Routledge.

Irigaray, L. 2000. Women on the Market. In French Feminism Reader, ed. K. Oliver, 211 - 26. Lanham and New York: Rowman \& Littlefield.

Karafyllis, N.C. 2008. Endogenous Design of Biofacts: Tissues and Networks in Bio Art and Life Science. In Sk-Interfaces: Exploding Borders - Creating Membranes in Art, Technology and Society, ed. J. Hauser, 43 - 58. Liverpool: FACT \& Liverpool University Press.

Kent, S. 1990. Border Territory. In Lifelines: Four British Artists. Liverpool: Exhibition Catalogue, Tate Gallery Liverpool.

Loy, M. 1997. Feminist Manifesto. In The Lost Lunar Baedeker: Poems of Mina Loy, ed. R. L. Conover, 153 -5. Manchester: Carcanet.

McKellar, L. 2007. The Word Made Flesh: Re-embodying the Madonna and Child in Helen Chadwick's One Flesh. In The Sacred and the Feminine: Imagination and Sexual Difference, ed. G. Pollock and V.T. Sauron, $202-12$. London and New York: I B Tauris \& Co Ltd.

Peppis, P. 2002. Rewriting Sex: Mina Loy, Marie Stopes, and Sexology. Modernism/modernity 9(4): $561-79$. 
Pollock, G. 1996. Inscriptions in the Feminine. In Inside the Visible: An Elliptical Traverse of $20^{\text {th }}$ century Art in, of and from the Feminine, ed. M. Catherine de Zegher, 67-88. Boston: MIT Press.

Pollock, G. 2001. Looking Back to the Future: Essays on Art, Life and Death. Amsterdam: Overseas Publishers Association.

Pollock, G. 2006. Femininity: Aporia or Sexual Difference?, int. to B. L. Ettinger. The Matrixial Borderspace, ed. B. Massumi, 1-38. Minneapolis and London: University of Minnesota Press.

Pollock, G. and V.T. Sauron, eds. 2007. The Sacred and the Feminine: Imagination and Sexual Difference. London and New York: I B Tauris \& Co Ltd.

Reodica, J. 2008. Feel Me, Touch Me: The hymNext Project. In Sk-Interfaces: Exploding Borders - Creating Membranes in Art, Technology and Society, ed. J. Hauser, 73-5. Liverpool: FACT \& Liverpool University Press.

Reodica, J. n.d. Sacred and Sacrilege: Body Symbolism in Art and Culture. http://phoresis.org/index.-

php?option $=$ com_content\&view $=$ article $\&$ id $=16$ :sacredsac\&catid $=36$ : artresear $\quad($ ac cessed 26 June 2009).

Robinson, H. 2006. Reading Art, Reading Irigaray: The Politics of Art By Women. London and New York: I. B. Tauris.

Stiritz, S.E. and B.M. Schiller. 2005. Transforming Feminine Categories: Genealogies of Virginity and Sainthood. In Journal of the American Psychoanalytic Association 53(4): $1133-59$.

Warner, M. 2000. Alone of All Her Sex: The Myth and Cult of the Virgin Mary. London: Vintage. 
Open-Access-Publikation im Sinne der CC-Lizenz BY-NC-ND 4.0 (C) 2010, V\&R unipress GmbH, Göttingen 


\section{Chapter 10: Exploring Mixed Realities and Scientific Visualisations in Art/Science Collaborations}

\section{Introduction}

As an artist/researcher whose practice has been located at the art/science nexus since 1998, I have consistently interrogated the ways in which visual culture and science interface. This research has involved reinterpreting scientific image data from the perspective of a visual artist and recontextualising contemporary biomedical research in interactive art installations that probe constructs of 'humanness'. In this essay I outline my experimental art/science projects, machina carnis (www.wavewriter.net) and the mellifera initiative (www.mellifera.cc), since they exemplify innovative methodologies and groundbreaking interdisciplinary strategies. Both mixed reality projects speculate on the effects, comparatively speaking, that the convergent and divergent elements of art and science have on concepts of the natural and the artificial as well as objectivity and subjectivity. Hence, the works also critically address the limitations of an androcentric worldview, sentience, consciousness and self-creation (autopoiesis). This critique will explore the visual complexities and effects of developing technologies on both art and science, and the emergence of hybridisations and productive cross-disciplinary outcomes.

\section{Science and Art}

It is pertinent to begin with a - necessarily brief - overview of the relationship between science and art. Historically, the conception of art and science as discrete disciplines arose in the nineteenth century when the more distinct epistemological foundation of science developed and the term 'scientist' was introduced. In earlier times investigators had adopted the evocative and all-embracing term 'natural philosopher' to describe themselves and their wideranging field of interests. Some natural philosophers met in groups that included diverse individuals like provincial manufacturers, professional men and gifted 
amateurs. An example of one such group of eighteenth century English renaissance men, united by a love of varied and imaginative scientific discussion, was the Lunar Society (Uglow 2002). As so-called scientific rigour subsequently emerged, the disciplines of art and science began to separate. Notions privileging objectivity developed with the burgeoning belief that the analytical sciences, with its more defined parameters, could accurately explain the workings of the universe. In this situation, the modern era was characterised by specialisation and professionalisation. These distinct and normative discursive formations affected both art and science. The scientific model during this period was an objective model, whilst art was object-based for the static and passive consumer. Consequently, both disciplines were restricted and influenced by the prevailing social constructs of their epoch.

The critical debate on the epistemological status of science emerged with John Dewey and others as early as the 1930s and can be seen as an extension of contemporary attempts in the humanities to broaden the disciplinary parameters. Dewey questioned "issues of how our various knowledge claims were warranted, and [...] that there was no difference in principle between the warranting of scientific and other types of claims (including aesthetic and moral ones)" (Phillips 1988, 38). His theories were generally ignored until the 1950s when a "gradual erosion of the credibility of logical positivism took place" (Phillips 1988, 38).

Feminism, too, has sought to broaden the epistemological status of science. Feminist critique has noted that the hard sciences are still frequently typified by a pure search for hidden truth in nature and matter that can be resistant to the intervention of other discourses. Nina Lykke cites the divide that exists between university faculties as an example of this. She points out that nature in literature is "inscribed in the world of art and language and supposed to be human" whilst nature in the biomedical sciences and physics is "described as non human and subject to natural laws" (Lykke 1996, 15). An important outcome of intellectual work by feminists such as Lykke challenging scientific notions of "universal and objective truths", is their contribution to the emergence of more flexible discursive spaces (Lykke 1996, 15). These insights have fostered increasingly open paradigms and are proving crucial to how artists think about the spaces within which to research and practice art.

Atists have had a continuous involvement in the visualisation of scientific representations of the body (Stafford 1993). However, as Robert Zwijnenberg argues in the opening chapter of this volume, this engagement was inevitably influenced by the cultural constructs of its era. The catalogue for the exhibition Spectacular Bodies at the Hayward Gallery in London also points to the historical and social implications of the intersections between medicine and art: 
The purpose of anatomical images during the period from the Renaissance to the nineteenth century had as much to do with what we would call aesthetics and theology as with the narrower intentions of medical illustrations as now understood [...] Rather, the disclosing of the 'divine architecture' that stood at the summit of God's Creation remained the central goal of anatomical representation across at least three centuries (Kemp \& Wallace 2000, 11).

Nowadays, artists are released from such constraints. They are no longer the main source of medical images for research purposes nor are they called upon to validate man's position at the pinnacle of 'Divine Creation'. Rather, at the beginning of the twenty-first century, artists are free to engage in interdisciplinary projects, assume a critical role and probe the implications of developing scientific discoveries upon a wide range of social, ethical and conceptual issues. Despite this increasing flexibility, at this point in time, the disciplines of art and science are still habitually regarded as divergent. This may be due to the fact that, realistically speaking, artists are set apart from scientists. They do not customarily possess the acumen nor have access to the high-end technologies with which the contemporary scientific researcher is, by definition, equipped. In the light of these specificities, it is evident that any artist who undertakes art/science collaborations will require apposite research strategies and methodologies.

\section{Art/Science Collaborative Methodologies}

Given that art/science collaborations are in their infancy, emergent methodologies are at the developmental stage and the parameters are still evolving. Increasingly open scientific research models and broadening epistemologies are enabling interested artists to research within receptive scientific contexts. Other expanded, interdisciplinary fields are also proving rewarding in the search for productive models and extended paradigms. For example, the introduction of qualitative research methods in some areas of the social sciences has prompted a shift from deductive to inductive methods. Differences are here defined as being "not in the percentage of structured and unstructured questions but in how open-ended the research process itself is" (Kidder and Fine 1987, 60). Patti Lather heralds this "decline of the absolutes" as 'postpositivism', which has "cleared methodology of prescribed rules and boundaries" (Lather 1986, 259). Lather's findings suggest that artist-researchers who adopt the role of independent investigators are in the position to bring different perspectives, complementary skills and contemporary methodologies to the habitually reified field of established scientific research practice. It is therefore logical to propose that participants in interdisciplinary collaborative research are navigating the 
spaces of what might be regarded as a mixed reality that represents more than the sum of its parts, thus creating outcomes that are best described as 'hybrid entities'.

The construct of a hybrid entity is invaluable to artists, such as myself, who engage with cutting-edge scientific research developments since it offers liberating alternative strategies for collaborations that facilitate imaginative, openended project outcomes. When I initially considered collaborating with a leader in the field of biomedical engineering, I had misgivings about the potential of my participation to generate a meaningful contribution. I was concerned that this potential would be perceived to be quite limited if it were measured in terms of more proscribed research paradigms. As Stephen Wilson points out in his assessment of the extent to which artist-researchers might contribute to technoscientific debates, "scientists and technology researchers who have devoted their entire professional lives to educating themselves about topics being investigated might be sceptical [...] [. Can] artists learn enough to engage in research at a non-dilettante level?" (Wilson 1996, 3). However, when both artist and scientist engage in less constrained interdisciplinary collaborations, they contribute to expanded imaginings. Furthermore, the outcomes of these collaborations represent the hybrid entity construct, mentioned above. This parameter shift is described by my former scientific collaborator, biomedical scientist, Dr. Victor Nurcombe:

I don't see the collaboration between you and I as anything like as quotidian as 'research at a non-dilettante level'. It could only really be considered as 'research' as I understand it, at a much more esoteric level; I would have thought we set out to do something quite 'other', something more open-ended. Research with other scientists is usually extremely focused and conducted within tight parameters; it's not about possibilities so much as progressively excluding as many possibilities as possible. Our work was conducted much more in the spirit of 'what if?' (Nurcombe 2005 , n.p.).

Consequently, this hybrid, experimental methodology enables an artist to enter a very different, specialist domain - in my case that of pioneering biomedical engineering - bringing to it the creative, disparate skills of a visual artist. Rather than seeking to emulate the established, modernist, scientific model, an openended flexible dialogic research relationship affords a reinterpretation of the research paradigm and a reappraisal of the structuring and meaning of 'knowledge' in this situation. This strategy fosters the production of a shared space for the mutual exchange of skills, leading to new understanding about, and appreciation of, the contribution of the hybrid entity in the wider disciplinary, collaborative context. 


\section{Machina Carnis}

One of the motivating factors behind my interest in working collaboratively in the scientific context has been my curiosity about culturally situated frameworks underpinning scientific enquiry and discovery. For the machina carnis project I entered the specialised laboratory environment, with the aim of exploring previously established scientific paradigms and research data from the perspective of a visual artist. I made a decision to complicate the so-called "Cartesian dualism of the disembodied eye" (Jay 1993, 81) by using my own cells as the material for experimentation, and also by carrying out the scientific processes myself. My strategy of direct participation in both the scientific processes of cell collection and the experimental laboratory techniques overcame the position of a passive observer.

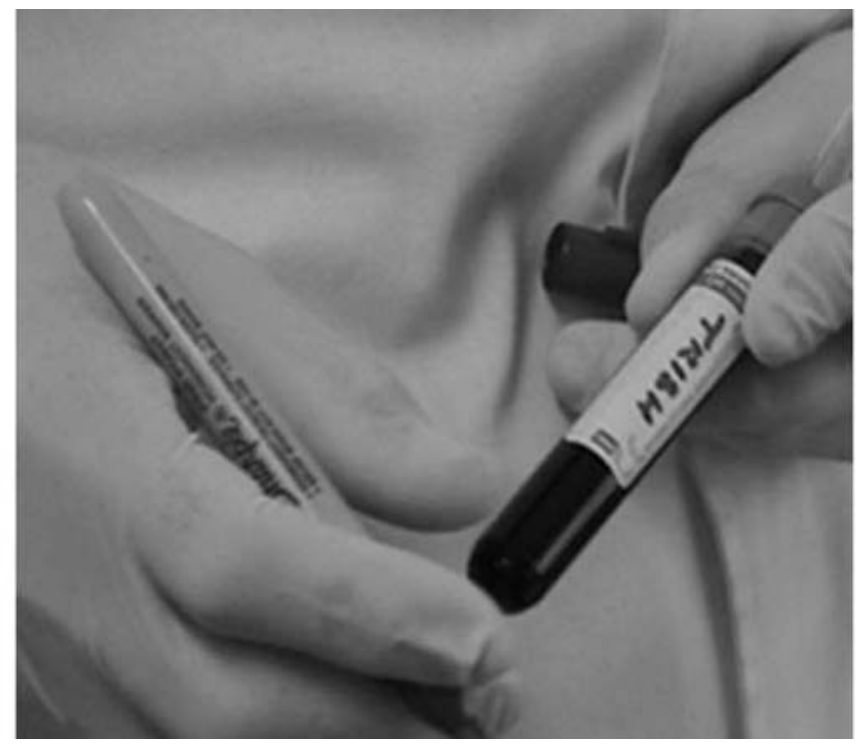

Figure 10.1: A doctor takes a sample of Trish Adams' blood for her experimental project. Photo Prof. V. Nurcombe. Courtesy Trish Adams.

It contravened the accepted norms of so-called objective research practice through the use of my own cells as the focus and site for my experiments, resulting in the hybrid amalgamation of research practice and research subject. I believed that my immersive, first-person participation in the role of artist/researcher would allow me to "probe the technology whilst existing in the new contexts created by it" (Wilson 1991, 433). In 2002, under strict ethical guidelines, a sample of my blood was taken and stem cells were collected from it. Then, with the direction and support of my scientific collaborator - in what was a first 
for a visual artist - I separated the adult stem cells from my blood sample and changed them into beating cardiac cells in vitro through the addition of a patented chemical growth-mix. The overall process took seven days and the beating cardiac cell images were captured by time-lapse digital video-microscopy.

In the laboratory phase of the machina carnis research project I became a human 'guinea pig' and also, in a sense, what might be regarded as a representative of generic humanness. My aim was to generate empathy through this evocative human link by incorporating the time-lapse digital video-micrograph documentation of the beating cardiac cells, cultured from my adult stem cells, into the machina carnis installation. Through the interactive, immersive structure of the installation viewers were positioned in the role of participants who brought the installation to life through their engagement with it. Due to the incorporation of discrete, interactive new media technologies installation visitors were able to engage with the artwork from the position of participants who were thus implicated in recontextualising the scientific data, mediated through art. This process of individual connection also encouraged installation participants to address underlying issues such as consciousness and sentience and what it might mean to be human at the beginning of the twenty-first century.

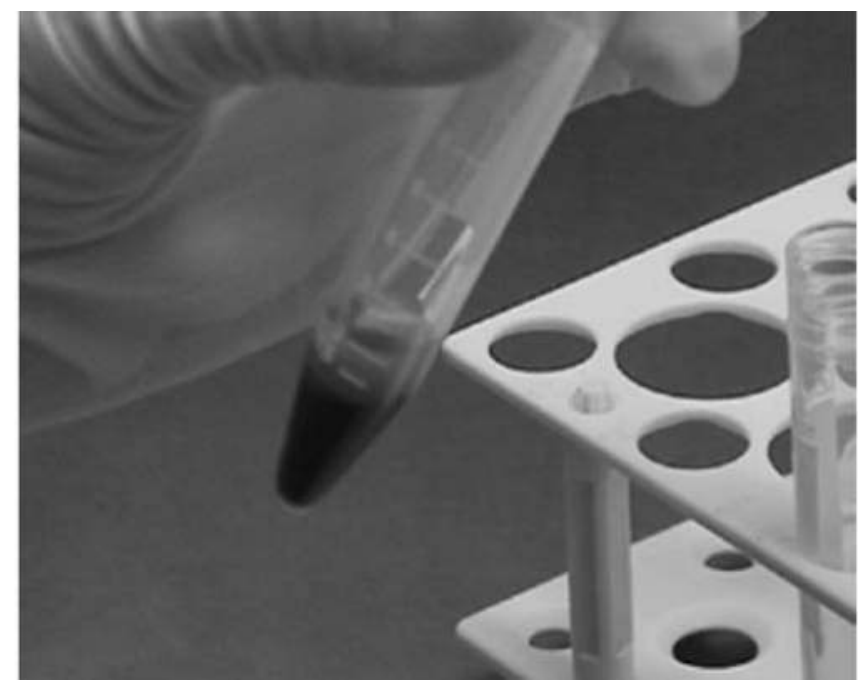

Figure 10.2: Trish Adams separates the stem cells from her blood in the laboratory. Photo Prof. V. Nurcombe. Courtesy Trish Adams. 
Mellifera

My observations of cellular behaviours during the machina carnis project raised many questions related to levels of consciousness in microscopic organisms. Research in this field is a central focus at the Queensland Brain Institute (QBI) of the University of Queensland in Australia. This is the location of the purposebuilt bee house, where I am currently collaborating with Professor Mandyam Srinivasan and the Visual and Sensory Neuroscience Group. Honeybees have "relatively simple nervous systems [that] nevertheless display a rich behavioural repertoire" and this group of scientists believe that there is much to be learned by exploring "the limits of the 'cognitive' capacities of small brains" (Srinivasan 2005 , n.p.). This initial collaboration has expanded to become a part of the mellifera initiative, which also includes fellow artist/researcher Dr. Andrew Burrell. Mellifera consists of terrain in the massively multi-user virtual environment (MMUVE) Second Life ${ }^{\circledast}$ (SL), which will subsequently be linked with interactive artworks situated at real-time installation nodes. Our direct engagement with various aspects of honeybee behaviour during our collaboration with the scientists is central to mellifera's methodology. Consequently our initial research processes involve hands-on data gathering, scientific interactions and observations.
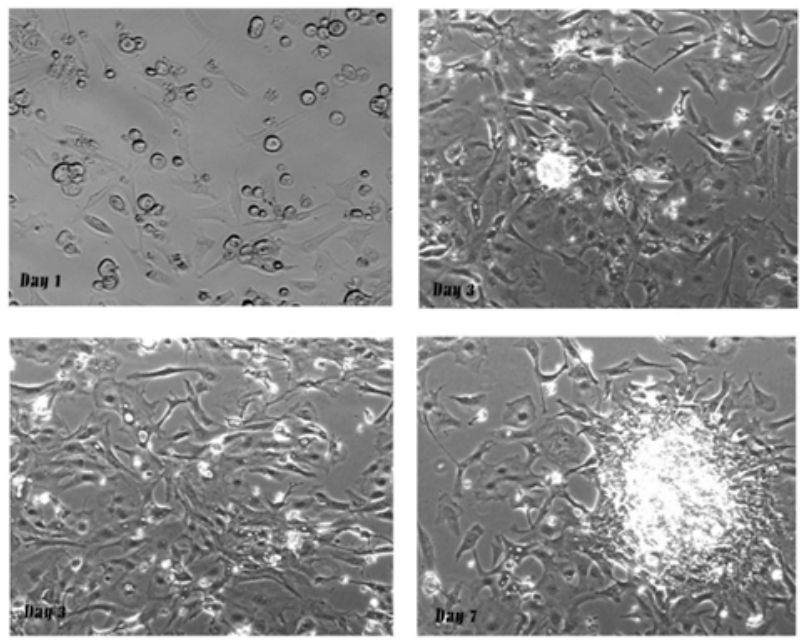

Figure 10.3: The stem cells from Trish Adams' blood sample shown 'changing fates' into beating cardiac cells over 7 days in culture. Courtesy Trish Adams. 
At the bee house we are collecting source material for our imaginative and technical reinterpretations in artworks. Of particular interest to us are the aspects of bee training, cognition, navigation, individual and hive communications, and the human readable language of the bee dances. We are focusing on possible links between mellifera's virtual organisms and the honeybee's cognitive processes and interactions. These will also inspire programming systems for the human/computer interfacing integral to mellifera's virtual and real-time interactive artworks. Mellifera's unique structure represents an important step forward in mixed-reality art works, challenging accepted templates of creative practice and multimedia representations. This is an ambitious project that takes both art/science collaborative methodologies and interactive technologies to new levels of complexity and, in the words of Ricardo Peach, Programme Manager at the Inter-Arts Office, Australia Council for the Arts, it is "about spaces opening up room for practices to flourish that are not limited to the physics of the natural universe" (Peach 2008, 36). In fact, the use of experimental methodologies enables both mellifera and machina carnis to interrogate contemporary constructs of humanness. They probe notions of identity and the ambiguities of embodiment through shifting the activity of viewing from a transparent relationship of meaning and expression to an immersive encounter with the 'self'. Reflecting upon relativistic constructs of the observer, these groundbreaking projects examine expressions of corporeality and moments of perception which exceed habitual boundaries.

\section{Concepts of Humanness and the Posthuman}

Concepts of humanness and perceived understandings of the structure of the human body are being rendered increasingly slippery and ambiguous by the rapid developments in biotechnological research. For instance, adult stem cell research is having an impact on our understanding of corporeality at the beginning of the twenty-first century. When I cultured my adult stem cells for the machina carnis project I aimed to probe the discourses surrounding genetic manipulation and the orthodoxies of being. The laboratory processes raised various ethical questions relating to the rights of organisms as living entities, for whom classification as human or non-human may be a matter of degree. When grappling with the complexities inherent in categorising my cells once they had been removed from my body and scientifically modified, I realised the extent of today's cultural fusion of the biological and the technological. As Smelik and Lykke put it: 
As life bits, whether carbon- or silicon-based, are transformed, the body threatens to fall apart into "components", to decompose down to its molecular structures, which can be reassembled in new and unexpected ways and remediated in endlessly changing shapes. The human body can no longer be figured either as a bounded entity or as a naturally given and distinct part of an unquestioned whole that is itself conceived as the "environment". The boundaries between bodies and their components are being blurred, together with those between bodies and larger ecosystems (Smelik and Lykke 2008, ix).

Different forms of interactions and cross-disciplinary connections have developed, resulting in the dematerialisation of the self and the material world. Monsters and cyborgs are seen as the inevitable 'others' that modernity would like to suppress, but cannot (Lykke and Braidotti 1996; Latour 1993; Haraway 1991). Donna Haraway famously blurs the boundaries between human and machine still further: "Perhaps cyborgs inhabit less the domains of 'life', with its developmental and organic temporalities, than 'life itself", with its temporalities embedded in communication enhancement and system redesign" (Haraway 1997, 12). As a trained biologist, Haraway frequently thinks in biological metaphors. This is exemplified in her stimulating question "How do technoscientific stem cells link up with each other in expected and unexpected ways and differentiate into entire worlds and ways of life?" (Haraway 1997, 130). She has selected stem cells as a symbol for rhizomatic pathways, connections and articulated systems. The depth and multiplicity of such pathways of technoscientific bodies "form nodes from interactions where all the actors are not human" (Meyer 2005, 1). Haraway uses technoscience as "materialized semiosis" (Haraway 1997) to explore the depths and multiplicity of relationality that distinguishes her critical practice, where "not all the actors have language, but they nevertheless can be caught up in signification" (Sofoulis 2003, 87). This construct of 'materialised semiosis' has impacted upon my attempts to clarify the status of my stem cells and also on my interrogation of multidisciplinary links and open-ended encounters that query conceptions of 'humanness' and 'selfhood'.

Such queries lead one to question how we can differentiate between the machine and the human being if some attributes are shared by both. The computer, for instance, is a language system that is separated from the human, while it also has characteristics that are identified with humans. Computergenerated avatars are an example of the various aspects of humanness that are blurred in this technological context. Whilst a comprehensive discussion of avatars in virtual worlds does not fall within the scope of this essay, it is informative to look beyond an avatar's immediate visual characteristics in order to consider notions of embodiment and online selfhood. In the case of avatars, and 
indeed that of computers in general, developmentally and ontologically we appear to be "addressing the space in which the human comes into being [...] [, that is] not only calling into question what language might be but also what it might be to be human" (Biggs 1998, n.p.). This is a significant reflection upon the fragile and permeable constructs of humanness from which it is only a small step towards notions of the 'posthuman'. These speculations have been extensively interrogated by Katherine Hayles, who introduces notions of the posthuman that instantiate the material body to such an extent that it is seen as informational patterns in which biological embodiment becomes accidental rather than inevitable (Hayles 1999). Rosi Braidotti, however, stresses the material roots of the posthuman as "an organic assemblage of forces that exceeds and challenges the boundaries of morphology" (Braidotti 2002, 159).

In response to contemporary research into digital technologies and the status of computer generated organisms in virtual worlds the mellifera initiative problematises constructs of the self. Drawing upon the 3D virtual environment and operating at the interface of transhumanism and cyborgology, mellifera explores the convergent spaces of biology and artifice. Through a series of human/computer interfaces that go towards providing a platform for adopting posthuman technologies and modes of sensory delivery, mellifera moves between virtual and real-time locations. In this way it increases viewer/participant fluidity and encourages further speculation about humanness and the nature of embodiment. Its conceptual focus on narratives, the role of the physical body and the implications of the tripartite relationship between the self, the avatar and artificial life, enables the mellifera initiative to provide opportunities for investigating various facets of identity. For example, the on-line audience interacts with Second Life through the portal of the SL screen view, whilst the gallery going audience interact via a completely new custom-built interface. This evolving process allows audiences to develop a relationship with the artificial life through the formation of their narratives, bringing the viewer face to face with the issues raised.

Conceptually speaking, in the context of living organisms, the virtual environment of mellifera's programmed self-generating systems and the microscopic cellular behaviours observed during the machina carnis project intersect with each other. The historical roots of the connections between biology, cybernetics and information theory are long established (Weiner, 1948). Therefore it is towards biology that we look for definitions and descriptions of living systems that move beyond the "Cartesian division between mind and matter" (Capra 1996, 170). In order to gain a practical understanding of life in biological terms, it is necessary to define the different levels at which organisms can exist. In the case of microscopic cellular organisms these may be regarded as "merely different aspects, or dimensions, of the same phenomenon of life" (Capra 1996, 
170). In other words, though different in scale, the macro and the micro resemble each other closely. Theories have developed seeking to explain cellular behaviours that appear to demonstrate levels of cognition and consciousness. These speculations differentiate between 'mind' as distinct from 'brain'. A prevailing example is the 'Santiago' theory:

The brain is not necessary for mind to exist. A bacterium, or a plant, has no brain but has a mind. The simplest organisms are capable of perception and thus of cognition. They do not see, but nevertheless perceive changes in their environment - differences between light and shadow, hot and cold, higher and lower concentrations of some chemical etc. (Capra 1996, 170).

The question under debate is more about what mechanisms enable microscopic cellular organisms to behave as they do.

These and other inquiries into the status of an organism, such as those of Evelyn Fox Keller, who worked for many years at the interface of physics and biology, point to the necessity to identify those special properties or features that distinguish a living system from a collection of inanimate matter (Fox Keller 2002). Fritjof Capra proposes that we should consider "the concept of selforganisation" and look to "the new mathematics of complexity" for an understanding of "the patterns that constitute living forms", since the configuration of components and the structure of these components are the characteristics of any organism both living and non-living (Capra 1996, 153). According to Capra, the essential defining element of a living system is the presence of a constant state of flux between individual parts and the capacity for self-regeneration, or process. The criteria that define living systems are summarised in three conceptual dimensions, "pattern, structure, and process" (Capra 1996, 156). Maturana and Varela call this pattern of life 'autopoiesis' and they use the example of cell structure to investigate the complexities of "autopoietic networks" because it is the simplest living structure (Capra 1996, 158).

\section{Scientific Imaging}

In the light of these previous definitions, the cells that were removed from my body and successfully cultured in the laboratory during the machina carnis project are examples of self-regenerating living systems. In the laboratory I have observed that in order to survive as living organisms outside their natural environment, these cells require regular food and have to be kept at a constant temperature of $35^{\circ} \mathrm{C}$. They do not like jets of fluid squirted at them directly but they can tolerate fibulation up and down at the end of a pipette. When disturbed 
they shrink up and they grow best on a secure foundation within reach of their neighbours. What prompts these specific preferences? These queries lead one to enquire to what extent these cells can be described as sentient beings. In this context, it is helpful to bear in mind that "sentience is not a scientific word; it is born out of psychology" (Kisher, 2002, n.p.) and therefore more widely applicable due to its socio-cultural focus. Thus, when my scientific collaborator and I employed anthropomorphic terms to describe the microscopic world, this was a consequence of the situated knowledge, imagination and common experiential vocabulary at our disposal. It has also been noted that other scientists such as Crick and Watson used terms like 'beautiful' for instance and privileged the concept of aesthetic symmetry during their documented investigations into the structure of DNA and their model constructions of the double helix (RootBernstein 1996, 48). The adult stem cells used in the machina carnis experiments were extracted from my blood. However, once they were removed, cultured and changed into cardiac cells in the laboratory, their status became more complicated and categorising them proved challenging.

Likewise, assigning characteristics to the computer-generated organisms in the virtual world of mellifera has been thought-provoking and exacting. It is suggested that "virtual embodiment is predicated on a discontinuity, the gap between virtual and actual" (Boellstorf 2008, 138). Evidently, an expansion of our scientific and philosophical frameworks is required to incorporate both an understanding of the characteristics of living organisms and the impact of recent digital technologies on this understanding. I refer not only to the epistemological advances resulting from increasingly sophisticated contemporary digital scientific techniques, but also to the ontological ambiguities inherent in the medium of digital imaging itself. For example, as developments in scientific research make inroads into accepted orthodoxies relating to the nature of consciousness and identity, the notion of the self as an entity with free will becomes increasingly complex. This is apparent in the case of neurological scientist Benjamin Libet's experimental study, which challenged our understanding of free will. Libet found that "electrically observable cerebral process [...] preceded the appearance of the subject's awareness of the consciousness to act by at least $350 \mathrm{msec}$ " (Libet 2004, 24). In other words, our brains commence motor commands before we are consciously aware of our choices, indicating that action is intuitively initiated, contrary to previous orthodoxy. Embracing the implications of these increasingly nuanced notions of free will and human behaviour, artists are exploring and problematising the identifiable self and the related uncertainties and impermanence of the human form.

Clearly, the demonstrated intricacies of emerging contemporary technologies - both visual and procedural - and their impact on artistic and scientific processes are having a continuous effect on the work of both artists and scien- 
tists. During my art/science practice I have had the opportunity to associate with advances in digital imaging technologies. Initially, I used light microscopes but eventually, under expert guidance, I drove the JSM Scanning Electron Microscope. This machine produces images by detecting secondary electrons which are emitted from the surface of the coated sample due to excitation by the primary electron beam. At this level, the position of the observer involves extensive prosthetic dependency and arguably a leap of faith. It necessitates trusting in the veracity of the machine with all its potential epistemic and technological limitations. Reliance on machinic interpretations prompts speculation about the status of scientific imaging. In this context, the relationship between machine and observer are particularly problematic if, in the words of Hayles, "the observer [...] does not so much discern pre-existing systems as create them through the very act of observation" (Hayles 1999, 131).

Scanning, tunnelling microscopes are in fact referred to as 'endo technology' and the science of endophysics addresses such issues as observer-relativity, representation, and non-locality; exploring what a system looks like when the observer becomes part of the system. Consequently, according to Peter Weibel, endophysics "emphasises the extent to which supposed 'objective reality' is necessarily dependent on the observer - or in this case the perspective of the machine - giving scientists a "view from within"' (Weibel 1992, 342). Karen Barad draws lessons from quantum physics in writing that "phenomena are not the mere result of laboratory exercises engineered by human subjects, nor can the apparatuses [...] be understood as mere observational devices or laboratory instruments" (Barad 2008, 173). In her posthumanist and materialist view, Barad argues that matter is an agent, and hence alive with possibilities. She concludes that life "in all its specific material configurations" is "an entangled agential performance of the world" (Barad 2008, 174). Thus, matter, machines and humans similarly act upon the world.

In seeming to reveal the so called "many worlds in this world", referred to at the advent of microscopy by Renaissance poet and scientist Margaret Cavendish (Cavendish 1668, n.p.), light microscopy generated curiosity and wonder about previously invisible worlds. This excitement about unknown territories has fired the imagination and is redolent with parallels to the utopian notions initially attributed by some commentators to contemporary virtual realities. My associations with the advanced digital imaging technologies incorporated into scientific research and documentation, led to my interrogation of the epistemological status of scientific imaging, computer-mediated representations and the effects of digital simulations.

The primary concern during the machina carnis project was how an artist might imaginatively reinterpret and recontextualise scientific research data in ways that would retain its impact, whilst moving away from the documentary 
context. For me, thinking through the reinterpretation of scientific image data involves speculation about how I could creatively effect disruptions to the habitual proscription inherent in the perception of representations. I became aware that "digitality provides a set of lived circumstances in which our senses encroach upon us in a different way" (Munster 2001, n.p.). From an artistic perspective the scientific data resonated with photographic moments of perception, in that it moved the activity of viewing from a transparent relationship of meaning and expression to a level in which significance seems to be there without the presence of subjectivity. In this context, the time-lapse video-micrograph cellular image data incorporated into machina carnis exceeded normal boundaries, creating an encounter with the self and other intensely individual associations. Consequently, this interactive artwork was characterised by complex interrelations involving the 'real' and the 'virtual', with which the viewer or participant became engaged in a dialogue.

Points of confluence occur when each participant combines his or her knowledge that the cardiac cells - represented in the image data - were cultured from adult stem cells, similar to their own. This awareness evokes intangible emotional and interpretative personal responses for each installation participant. In the case of the mellifera terrain, participants are confronted with an entirely virtual environment which is also sometimes mediated through realtime interactivity. The project's intention is to create spaces for both on-line and real-time flexibility of interaction - fostering imaginative reflections on identity and selfhood.

\section{Conclusion}

In the course of this discussion of the various tools and theories that underpin my arts/research practice, I have explored aspects of convergence and divergence in visual culture and science. Both the machina carnis project and the mellifera initiative have probed the role of interactivity in new media art in crossing the consciousness divide through the interplay between the real-time installations, remote Internet access and virtual environments. Expanding upon the sites of exchange between digital technologies and the ambiguity of data flow and bodily presence has led to a deliberation on contemporary notions of virtual identities and mixed realities. In the case of the machina carnis project, the plight of the genetically engineered human has formed a focus of cultural critique through an examination of the relationship and implications of biomedical engineering on expressions and representations of corporeality.

Further dimensions of 'corporeality', 'identity' and the 'self' were also central to the mellifera initiative. The developing relational systems that evolved during 
these projects suggests that the term 'corporeality' encompasses more than just a biological definition per se; rather it appears to be embedded within the wider network of notions of living/non-living and constructs of humanness. Both projects have involved art/science collaborations and, through experimentation, have expanded upon potentially transgressive, innovative interdisciplinary methodologies. The projects that I outlined in this text, mediated scientific research data through artistic practice, and thus represent potential starting points for interrogations of the self and explorations into expressions of corporeality. These include developments - both virtual and biomedical - in the field of mixed realities at the art/science nexus, with a particular focus on the relationship between the imaginary in visual culture and the permeable boundaries existing between art and science during collaborative interdisciplinary projects.

\section{Bibliography}

Barad, K. 2008. Living in a Posthumanist Material World. Lessons from Schrödinger's Cat. In Bits of Life. Feminism at the Intersections of Media, Bioscience, and Technology, eds. A. Smelik and N. Lykke, 165-76. Seattle: Washington University Press.

Biggs, S. 1998. Question Our Question. In Shock of the View. http://www.artsconnected. org:8080/read?246,19. (accessed January 2, 2002).

Boellstorff, T. 2008. Coming of Age in Second Life. Princeton: Princeton University Press.

Braidotti, R. 2002. Metamorphoses. Towards a Materialist Theory of Becoming. Oxford: Polity Press.

Capra, F. 1996. The Web of Life. London: Harper Collins.

Cavendish, M., Duchess of Newcastle. 1668. Of Many Worlds in This World. In The Wadsworth Anthology of Poetry. J. Parini. 2006. Boston: Wadsworth Thomson.

Fox Keller, E. 2002. Marrying the Premodern to the Postmodern: Computers and Organisms After WW11. In Prefiguring Cyberculture: An Intellectual History, eds. D. Tofts, A. Johnson, and A. Cavallaro, 52 -65. Sydney: Power Publications.

Haraway, D. 1991. A Cyborg Manifesto: Science, Technology, and Socialist-Feminism in the Late Twentieth Century. In Simians, Cyborgs and Women: The Reinvention of Nature, 149-81. New York; Routledge.

Haraway, D. 1997. Modest_Witness@Second_Millennium.FemaleMan@_Meets_OncoMouse ${ }^{\mathrm{TM}}$. London \& NY: Routledge.

Hayles, N.K. 1999. How we Became Posthuman: Virtual Bodies in Cybernetics, Literature \& Informatics. Chicago \& London: University of Chicago Press.

Jay, M. 1993. Downcast Eyes: the Denigration of Vision in Twentieth Century French Thought. Berkley: University of California Press.

Kemp, M., and M. Wallace. 2000. Spectacular Bodies. London: Hayward Galleries Publishing.

Kidder, L., and M. Fine. 1987. Qualitative and Quantitative Methods: When Stories 
Converge. In Multiple Methods in Program Evaluation, eds. M. Mark, and R.L. Schotland. San Francisco: Jossey-Bass.

Kisher, W. 2002. Let's be Factual About the Human Embryo. www.all.org/abac/ab020128. htm (accessed March 6, 2004).

Lather, P. 1986. Research as Praxis. The Harvard Educational Review 56(3): 257-277. Latour, B. 1993. We Have Never Been Modern. London: Harvester Wheatsheaf.

Libet, B. 2004. Mind Time: the Temporal Factor in Consciousness. Cambridge, MA: Harvard University Press.

Lykke, N. and R. Braidotti, eds. 1996. Between Monsters, Goddesses and Cyborgs: Feminist Confrontations with Science, Medicine and Cyberspace. New Jersey: Zed Books.

Meyer, S. The Inner Limits: Tender Buttons. http://www.stanford.edu/dept/HPS/Wri tingScience/s_meyer.html. (accessed March 18, 2005).

Munster, A. 2001. Digitality: Approximate Aesthetics. www.ctheory.net/printer.as px?id=290. (accessed June 15, 2006).

Nurcombe, V. 2005. E-interview by Patricia Adams. In The Implications for Artistic Expressions and Representations of Corporeality of the Experimental Techniques of Biomedical Engineering, P. Adams, Appendix v. Doctor of Visual Arts Thesis, Griffith University.

Peach, R. 2008. The Second Life Funding Landscape, ed. K. Gallasch. Real Time 87. OctNov: 36. http://www.realtimearts.net/article/issue87/9181 (accessed January 2, 2009).

Phillips, D.C. 1988. On What Scientists Know and How They Know It. In Learning and Teaching: The Way of Knowing, ed. E. Eisner, 37-59. Chicago: National Society for the Study of Education.

Root-Bernstein, R. Spring 1996. Do We Have the Structure of DNA Right? Aesthetic Assumptions, Visual Conventions, and Unsolved Problems. Art Journal 55(1): 47 - 55.

Shotland, L. Fall 1987 New Directions for Program Evaluation. 35: 57 - 75. San Francisco: Jossey Bass.

Smelik, A. and N. Lykke, eds. 2008. Bits of Life. Feminism at the Intersections of Media, Bioscience, and Technology. Washington: Washington University Press.

Sofoulis, Z. 2003. Cyberquake: Harraway's Manifesto. In Prefiguring Cyberculture: An Intellectual History, eds. D. Tofts, A. Johnson, and A. Cavallaro, 84-103. Sydney: Power Publications.

Srinivasan, M. 2005. Research Group Leaders, Visual and Sensory Neuroscience. http:// www.qbi.uq.edu.au//index.html?page $=52793$

Stafford, B. 1993. Body Criticism: Imaging the Unseen in Enlightenment Art and Medicine. Cambridge, Mass.: MIT Press.

Uglow, J. 2002. The Lunar Men: The Friends Who Made the Future 1730-1810. London: Faber.

Weibel, P. 1992. Endo \& Nano - Over and Beyond the Limits of Reality. In Die Welt von Innen: Endo und Nano, eds. K. Gerbel and P. Weibel. Ars Electronica Austria: Conference Publication.

Wiener, N. 1948. Cybernetics, or Control and Communication in the Animal and the Machine. Paris: Hermann and Co., Cambridge: The Technology Press, and New York: John Wiley and Sons.

Wilson, S. 1991. Technological Research and Development as a Source of Ideas and Inspiration for Artists. Leonardo 24(4): $433-440$. 
Wilson, S. 1996. Art as Research. http://www.sfsu.edu/ swilson/papers/artist.researcher. html. 
Open-Access-Publikation im Sinne der CC-Lizenz BY-NC-ND 4.0 (C) 2010, V\&R unipress GmbH, Göttingen 


\section{Catherine Fargher and Terumi Narushima}

\section{Chapter 11: Knit Two Together: Art/ Science Collaborations in BioHome. The Chromosome Knitting Project}

\section{Introduction}

Welcome to BioHome ${ }^{\mathrm{TM}}$ ! In a few moments, ladies and gentleman, you and your families will be able to enter the model biotech home and see the range of rooms and products that are on display for you today. We have a fully appointed kitchen, nursery, lounge room and bedroom, even a miniature biotechnology display home. Today you will experience the latest in biotech science as it meets the everyday technologies of your home. Explore the products on offer and make up your own minds! Feel free to experience ChromoKnit ${ }^{\mathrm{TM}}$ technology. We think you'll agree that some of our products promise an amazing future for you and your children, but there are some traditional comforts as well. Take time to relax, interact and try things out. It's yours to explore. Please enter and enjoy BioHome ${ }^{\text {TM }}$.

With this opening sales pitch, delivered by performer Catherine Fargher, the audience is invited to enter the installation BioHome: The Chromosome Knitting Project. BioHome is a hybrid performance/installation incorporating live wet biology practices in a contemporary biotech display home. ${ }^{1}$

BioHome has been developed to exist in a range of contexts: scientific laboratories, conferences, galleries and museums, as well as theatrical and performance contexts. ${ }^{2}$ In the context of this project, 'wet biology' is the term used for working with live plant or animal material, and includes genetic modification of organisms as well as the creation of bioproducts such as DNA fibres and live

1 BioHome: The Chromosome Knitting Project was first presented at the University of Wollongong, Australia, in August 2006 and again at the exhibition Biotech and Art Revisited, curated by Melentie Pandilovski at the Experimental Art Foundation, Adelaide South Australia in April 2009.

2 Excerpts of the work have been performed at conferences such as the Australasian Computer Music Conference and ADSA (Australian Drama Studies Association) National Conferences and theatre festivals such as Playworks' Invisible Boxes. Film footage has been displayed at the SCINEMA program for Australian National Science Week. 


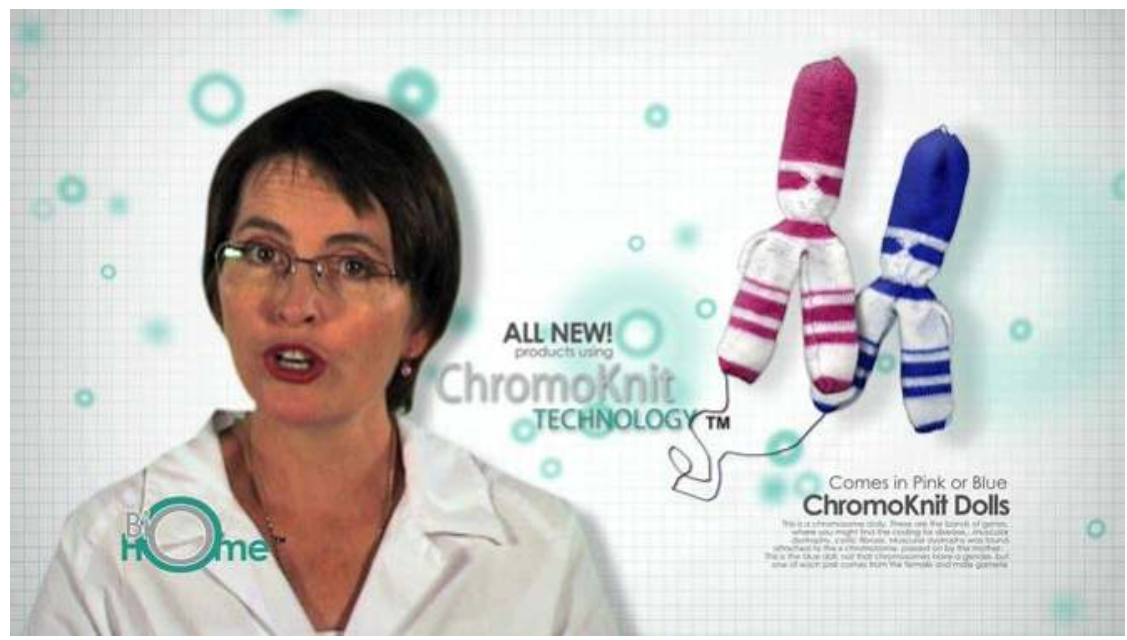

Figure 11.1: BioHome welcome screen video. Photo Gregory Clout, Robert Dinnerville, Jessica Ellis. Courtesy Catherine Fargher and Terumi Narushima.

cell cultures. The installation features video, interactive sound, live theatre and text to explore reproductive futures and biotechnologies.

In this essay we will present a case study of our project BioHome: The Chromosome Knitting Project. This study will reflect on a number of outcomes of the art/science collaborative process and how they relate to the scientific imaginary in visual culture, namely:

- The influence of the postnatural environment on contemporary performance and art forms;

- Art/science collaborations and the challenge to present rather than represent live science in art;

- The collaborative process and resultant hybrid forms: the hybridising of sound, wet biology, text and performance;

- Ways in which hybridity in the natural and technological realms inform current arts practices.

\section{Transformed Nature}

Before discussing in more detail the actual artwork BioHome, we want to briefly sketch the theoretical background that has informed our art practice. At present, nature is being manipulated and changed rapidly by biotech science. This transformation of nature as we experience it today seems dramatic, mainly because of the accelerated rate of scientific and technological developments as 
opposed to the slower pace of evolutionary change. The rapid incorporation of biotechnologies and life-science products and procedures is blurring the boundaries between nature and technology, as well as creating a sense of both excitement and fear in the media and society. Sociologist Sarah Franklin suggests that cloning, genetics and the changes that flow from them:

affect the human condition in its every aspect, the food we eat, to the ways we define health, to our national economies, to our understandings of the human, the future and ourselves [...] from our models of the world economy to what it is to be a parent, genetics is reshaping the basic concepts through which knowledge about ourselves and our world is produced. It is for the same reason that these engender conflicting feelings of excitement and anxiety (Franklin 2001, 2).

Exploring the original posthuman monster of Frankenstein, Catherine Waldby goes further: "The possible application of these techniques to human beings is a topic of constant journalistic speculation and bioethical condemnation, and has produced anxious legislation to try to control the distinction between human and non-human technogesis" (Waldby 2002, 179). The resulting social and legislative anxiety, often exploited through the media, forms one basis for BioHome. In light of increased biotechnological intervention this transformed social and natural environment could be dubbed 'postnatural' as an alternative to 'posthuman', a term developed by theorists such as Rosi Braidotti (2002; see also Braidotti's article in this volume). It is not just human bodies but all of nature which is being 'reworked,' to use Franklin's term:

We need a redefinition of nature as 'reworked', nature clearly can no longer be seen as independent from the human and therefore existing prior to culture. Thus, not only does the name no longer provide us with a system that describes a precultural, human free condition, it can be read only in terms of a cultural map of the human (Franklin, Stacey, and Lury 2000, 70).

This concept is reflected in Elizabeth Grosz's claim that transformation of nature is inherent to all biological phenomena. She postulates that constant growth and variation has the effect of hybridising not only natural objects but also cultural, political and sociological phenomena as well. She states: "Biology does not limit social, political and personal life; it not only makes them possible, it ensures that they endlessly transform themselves and thus stimulate biology into further selftransformation" (Grosz 2005, 1). Theoretical concepts of the postnatural and reworked nature suggest that technological and natural transformations can be explored through creative works. This is what we have tried to do in our hybrid performance/installation BioHome. 


\section{Hybrid Arts}

BioHome explores the postnatural environment in which we live and our responses to genetically engineered, modified and transformed natures. How do we react to accelerated change? How do we respond creatively to ethical considerations of genetic modification and cloning as well as depictions in popular science of these amazing scientific feats? What sort of myths and stories do we create for ourselves to deal with these issues? While examining these questions it became apparent that biological principles of change and transformation could equally apply as a metaphor for creative forms as they evolve and mutate under the impact of new technologies to form new hybrid art forms.

A hybrid can be "a thing composed of incongruous elements" or "produced by cross-breeding or cross-fertilisation" (Shorter Oxford Dictionary 1993, 1285). Hybrid arts involve cross-fertilisation of art forms through creative partnerships with industry, science and other knowledge bases, such as critical theory. Hybrid practice encourages collaboration between art forms and the presentation and documentation of results from these cross-fertilisations. BioHome is an example of such an interdisciplinary art form: its creator Catherine Fargher, whose background is mainly in writing and performance, collaborated with numerous experts from both science and the arts. Details of these collaborations will be discussed in the following sections. Most significant amongst these was her partnership with sound artist Terumi Narushima, who created an interactive soundscape for the BioHome installation as well as providing live music for the theatre performance which is presented within the installation space.

Science in Art: Presentation, not Representation

Hybrid artist Stephen Wilson suggests that artists must work differently from their usual process to participate in the world of scientific research. He states: "They must broaden their definitions of art materials and contexts. They must become curious about scientific and technological research and acquire the skills and knowledge that will allow them to significantly participate in these worlds" (Wilson 2002, 50). As artists, our understanding of biotech issues was facilitated by our participation in a workshop run by SymbioticA, the science and art collaborative research laboratory within the School of Anatomy and Human Biology at The University of Western Australia. ${ }^{3}$ Through hands-on activities we were introduced to DNA extraction, genetic engineering, and tissue

3 http://www.symbiotica.uwa.edu.au/ 
culturing techniques. Workshop conveners Oron Catts and Gary Cass encouraged us to explore the life sciences, to see the semi-living organisms we created as vulnerable, rather than monstrous. They suggested that artists who create works dealing with biotechnology need to engage with the real science that they are critiquing:

Artists must immerse themselves in the dialectics of new knowledge and technologies. They must adopt not just a representational approach but what we refer to as 'wet engagement'. Hence, artists researching and exploring the role of biotechnology in society can and should engage with the actual technologies and get their hands wet and dirty (Catts and Zurr 2005, 22).

This imperative suggested an important direction for the BioHome project: to present this science live, rather than merely represent it through a mediated form. Fargher was inspired to incorporate wet biology practice within the performance, to allow the audience to grapple with ethical questions from the variety of meanings created. Previously, these technologies had been used by visual and installation artists under the label of 'bioart', but they have been rarely presented in a performance context. Perhaps this is a new form of performance that could be labelled 'bioperformance'.

\section{Ethics of Engagement}

Engagement with biotech science on a practical, hands-on level in a working laboratory highlighted many ethical issues that needed to be negotiated, including use of animal products such as serum containing calf foetus for culturing cells. These ethical considerations came down to a case-by-case assessment of risks and responsibilities. As bioartist George Gessert asked:

Do artists cross the line when they breed plants and animals, or use the tools of biotechnology? Scientists regularly cross the line, so do farmers, military men, business people and doctors. Only artists and various religious people hesitate. To the extent that art favours awareness, the more artists that cross the line the better (Gessert 2003, 47).

Fargher described her own experience as follows:

During this workshop, I was at the 'coal face' of the science we are debating at a public level, and it was both exciting, an ethical mine field, and confronting at a deep level - the very reasons I had started to explore these issues in the first place. 
Most exciting was the discovery that I can in fact knit DNA in its dried form (Fargher 2005, 17).

Working within the domain of wet biology fuelled a creative fascination with the potentials of this domain of science, as well as the discovery that there are many spaces that can be inhabited, and processes that can inform creative working methods. Fargher's instinct for curiosity pushed her across the ethical line and continued to keep her there. Thus in the practice of the art/science nexus, the lines that artists may have refused to cross previously can be crossed more easily once the science and technology are encountered.

\section{Art/Science Collaborations}

Curator Melentie Pandilovski suggested in his introduction to the Biotech Culture Symposium 2004 that in order for artists today to develop relevant bioart projects they must provide a clear context; a compilation of data (bio, genetic, electronic or other); and an established relationship between the artists and biologists/geneticists. To this end, Fargher collaborated with scientists in a number of university laboratories during the development stage of the work. Collaborations with scientists have in fact raised many issues around methodologies, ethics and roles of artists working with scientists, which we will not discuss here for reasons of space (issues of cross-form collaboration are discussed in the work of Wilson (2005), Munster (2005) and others). Fargher initially consulted SymbioticA director Oron Catts and Associate Professor Mark Wilson at the School of Biological Sciences, University of Wollongong, on the use of live caterpillar pupae cells to depict reproducing life forms in the installation. She was instructed in methods of culturing live cells, including feeding, maintenance and disposal. Immersion in laboratories gave insight into how scientists work. For example, they often work in small collaborative teams, not unlike theatre and arts practitioners, and there is a sense of coming and going as scientists maintain their experiments and wait for results. Stories of waiting for cells to divide, and the pastimes that scientists need to find as they wait (playing solitaire on the computer, or having a drink at the pub) were incorporated into the BioHome script. Also, video footage from the labs was used in the installation.

Development of plant based biotechnology involved working with molecular biologist Dr Ren Zhang from the School of Biological Sciences, University of Wollongong, and $\mathrm{PhD}$ candidate Somanath Bhat. These biologists assisted in experiments to extract large quantities of DNA from a range of plant materials, including corn, potatoes and wheat germ, with an aim to dry, spin and physically 
'knit' that DNA. When these attempts failed to produce a knittable product, Fargher developed methods to knit live DNA using a commercial product, salmon testes DNA, from Sigma Aldrich Life Science Corporation, one of the sponsors of BioHome.

Sponsorship from international biotech companies has been a key source of in-kind support for the BioHome project. ${ }^{4}$ The performance has been made possible thanks to sponsorship for salmon testes DNA and sf9 (the caterpillar pupae) cell products, as well as laboratory equipment from biotech corporations Invitrogen, Sigma Aldrich South Pacific, and also Eppendorf South Pacific. While the project did not seek to critique directly any sponsoring corporations, the audience was allowed to draw their own ethical conclusions about these products from information presented in the performance. These products, including centrifuges and cell warmers from Eppendorf, were worth thousands of dollars on the commercial market. Of course, acquisition of biotech products from such corporations raises ethical concerns, as highlighted in the artworks of Sub Rosa, a feminist collective exposing the ethical concerns behind a large number of pharmaceutical companies utilising biotechnologies. ${ }^{5}$ While being aware of these concerns, specific checks were not made on the ethical status of these corporations in the BioHome project, as this was not the main focus of the performance. Anther ethical issue is the increased legislation and corporate control around the area of biotech property rights, because of the increasing privatisation in the area of biotech production. On the whole, independent artists are not able to acquire these products without collaboration with a university biology department, giving rise to legal and ethical issues. ${ }^{6}$

The BioHome project not only included collaborations with scientists, but also with artists. A promotional video, web site and branding logos for BioHome were developed in collaboration with Gregory Clout, Robert Dinnerville and Jessica Ellis, a team of new media and graphic design students from the Faculty

4 Interestingly Catherine Fargher used the sponsorship aspect of the work to sell and promote the project in certain science areas (Australian Broadcasting Commission / Department of Education Science Training, National Science Week funding), and also to the Australia Council for the Arts and the New South Wales Arts Ministry. The involvement of biotech companies actually worked as a means of promoting the work.

5 SubRosa is a cyberfeminist cell of cultural researchers committed to combining art, activism and politics to explore and critique the effects of biotechnologies on women's bodies, lives and work: http://www.cyberfeminism.net/.

6 FBI investigation of Steve Kurtz, Associate Professor in the Department of Art at the State University of New York's University at Buffalo, in 2004 is a case in point. Kurtz is a member of the internationally acclaimed Critical Art Ensemble whose artwork educates the public about the politics of biotechnology. Following the death of his wife, bio-terror investigations were commenced at Kurtz's home studio/laboratory and his collaborator, a university science academic, received a charge of 'wire fraud' in relation to acquisition of bio-products for Kurtz's artworks. 
of Creative Arts, University of Wollongong. Fargher also worked with dramaturg Nikki Heywood to explore the subjectivities of different 'personas" ${ }^{7}$ and the internal imagery of cellular space, DNA strands and molecular movement using 'Body Weather' techniques. ${ }^{8}$ She also worked with other theatre and video artists during the development of BioHome.

\section{BioHome Installation}

Let us now describe the BioHome artwork in more detail. Visitors are welcomed to the BioHome installation by a plasma screen video introduction at the entrance, as was mentioned in the introduction of this essay (see Fig. 11.1). When the audience enters the installation space they hear a recorded voice outlining laboratory safety instructions over ambient but unsettling music. This music creates a sense of an insulated environment, a world that might exist just beyond our current reality, in which home and laboratory intersect. Upon entering, the gallery audience members are encouraged to wear laboratory safety clothing. They see several domestic spaces: a kitchen tabletop, a bassinette, a chair with knitting, and a bed with a screen. It is only when they inspect more closely that this domesticity is disrupted by the intriguing and uncomfortable presence of biotech products, including live caterpillar cell cultures, salmon DNA fibres, pea seedling DNA and IVF hormone products.

The blurring of lines between laboratory and domestic procedures aims to heighten the awareness and discomfort that the audience may feel about incorporation of biotech products in our daily lives. Further documentation is provided on a computer where visitors can look at reference material on topics such as reproductive technologies and IVF treatment, 'do it yourself' DNA extraction, and cell culturing. They can listen to interviews with scientists working with new biotechnologies, as well as play with an interactive music interface. In this way, visitors are encouraged to investigate and interrogate these technologies and their impact on human, social and environmental futures and contemporary kinship systems.

BioHome has strong links to theatrical performance and modes of presentation, even though it was exhibited within a gallery context. After the initial audience participation, the audience can then view a more clearly defined theatrical performance, separating the performer from the audience through the

7 The postmodern strategy of depicting performance personas was used by a number of practitioners in the 1990s such as Deborah Levy, Coco Fusco and Guillermo Gómez-Peña.

8 'Body Weather' techniques are based on Japanese Butoh, and used by performer Tess de Quincey: www.bodyweather.net. 
use of a small stage, and presenting a work that is clearly scripted and lasts for approximately 30 minutes. This is all presented within the installation setting. The resulting aim is to create a range of meanings for the audience and encourage ethical questioning of the subject matter. The performance includes a number of personas all played by Fargher: a naïve and eccentric housewife who invites newcomers into the biotech display home, exploring objects and products with a domestic simplicity and innocence; a woman who undergoes IVF treatment; a scientist who calls for volunteers from the audience to participate in an experiment to extract DNA from snow pea seedlings, as well as demonstrating how to knit with a sticky white fibre extracted from salmon DNA (Fig. 11.2); and a storyteller who recounts a fable about 'The Woman Who Knitted Herself A Child'.

In this fable a woman dreams that the experiment she is working on may become a real child; that a spirit is waiting to be embodied. To do this, she begins to knit herself a doll. At the same time, in her practice as a scientist, she is making a transgenic creature, literally postnatural in its generation, by introducing cloned cells into an egg nucleus. In the words of the story:

The wool curled around the needle and my arm, it snaked through the air and twisted around my Petri dishes, scooping up the cells, forming shapes that I didn't recognise. Tiny blobs which resembled the buds of limbs. A long chain stitch like the glimmer of a spine. I cleared a corner of the bench and started to assemble six jars, one for the buds of tiny hands, one for the blinks of the eyes, one for the downy hair on my baby's head [...]

By virtue of the mutation and hybridity inherent in its subject matter, this fable evolved and grew into what eventually became the final hybrid art form of BioHome. With the fable as a starting point, knitting became a central metaphor in the performance, highlighting similarities between the use of patterns and stitches in knitting to the basic techniques of biotechnology or genetic engineering, i.e. working with DNA as the building blocks of life. It was also a metaphor for human reproduction. Alongside knitting DNA in performance (see Fig. 11.2), Fargher commissioned her colleague Pamela Drysdale to knit a series of ChromoKnit Dollies based on images of her son's chromosomes, taken after Fargher's amniocentesis test. These dollies were used as puppets in the performance. For example, the doll is used as a puppet to demonstrate IVF procedures and also packaged as part of the branding in BioHome.

With the metaphor of knitting, BioHome located itself in a resurgence of interest in knitting as a craft as well as an interdisciplinary tool in contemporary (cyber) theory. Theorists such as Sadie Plant (2003) and visual artists such as Cat 


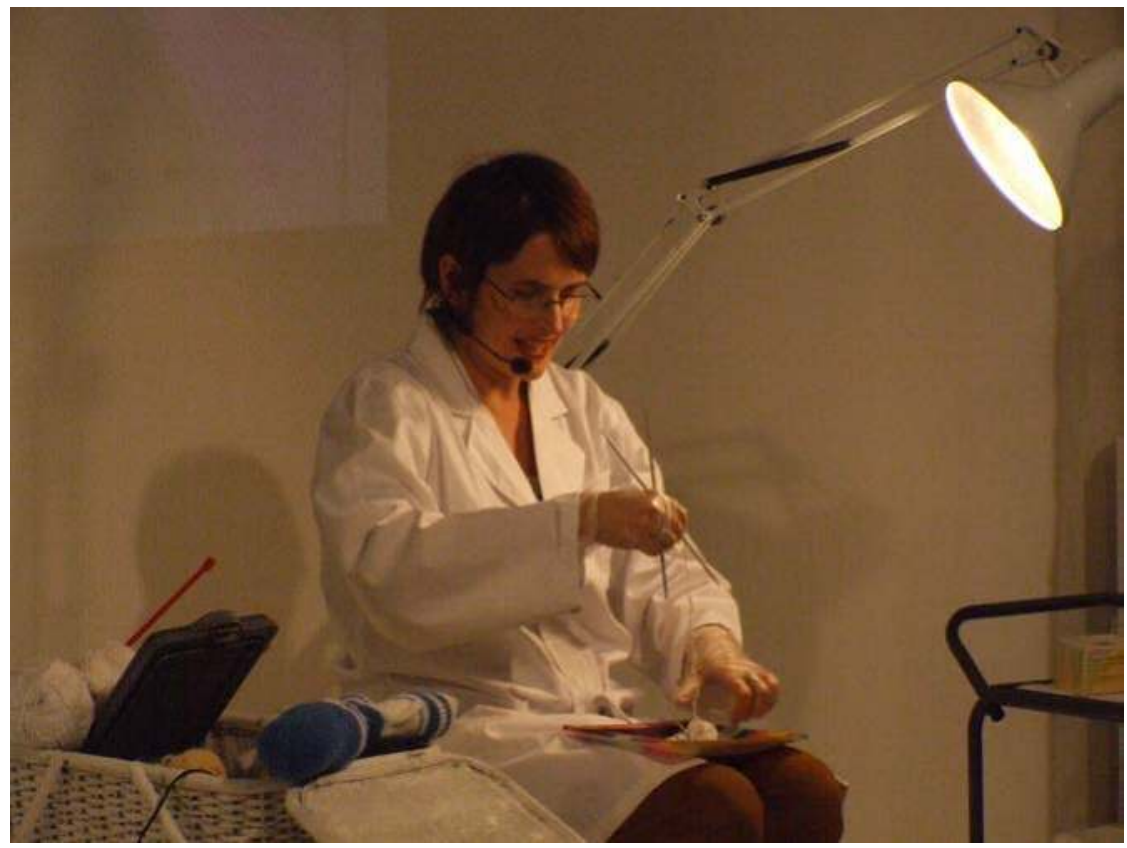

Figure 11.2: Knitting salmon DNA. Photo Russell Emerson. Courtesy Catherine Fargher and Terumi Narushima.

Mazza have used knitting both as metaphor and practical creative strategy. ${ }^{9}$ For instance, Mazza's Knitoscope Testimonies translates digital video of testimonies against sweatshop labour into a knitted animation. Other knitting and new media explorations include hybridising of biology and knitting, which was the subject of a journalistic article in the Australian knitting magazine Yarn that also featured BioHome; Fargher was approached to document the project along with other 'knitting biologists' ${ }^{10}$ The World Wide Web also features patterns for DNA helix jumpers and a blog for the knitting biologist who creates patterns from her experiments. The interest in knitting as an interdisciplinary tool, and cogent metaphor in areas of cyber arts, data retrieval and biological modelling, thus puts our performance in a broader context.

9 Turbulence Commission: "Knitoscope Testimonies" by Cat Mazza, who is "the founder of microRevolt which is responsible for a series of art projects that combine knitting, machines, and digital social networks to educate about the sweatshop crisis": http://turbulence.org/ works/microRevolt.

10 http://www.yarnmagazine.com.au/knitlit/kip_issue3.html 
Sound was important as an integral element of the installation and performance. The challenge in designing the sound for BioHome was to devise a way to relate DNA sequences with knitting through the medium of music. The sound requirements of the project were twofold: to provide an interactive interface for visitors to manipulate the soundscape of the installation; and to provide a live musical accompaniment to the theatre performance which is presented within the installation space. Much work has been done in sonification of DNA sequences by musicians collaborating with scientists (Dunn \& Clark 1999). In keeping with the domesticity of BioHome a homespun approach to DNA was taken for this project.

There is a technique used by molecular biologists to analyse strands of DNA called 'gel electrophoresis'. This process results in a visual representation in which fragments of DNA are separated into bands. To create a unique musical timbre for BioHome, these DNA band patterns were reinterpreted as overtones of an inharmonic sound spectrum and metallic, gong-like sound was synthesised using Pure Data (Pd) music software. This timbre was then used to play melodic sequences based on various knitting patterns.

A large number of standard pattern stitches used in knitting have names that refer to nature, such as 'moss', 'herringbone' and 'honeycomb' stitches. The idea was to represent these knitting patterns as patterns in sound. The most obvious approach was to assign random values to the different knitting stitches (e.g. 1 for knit, 2 for purl, etc.) to create simple melodic sequences. The limited number of stitch types, however, resulted in little variation in the patterns, so further modifications were made by changing rhythm and tempo, detuning pitches and applying various filters to alter the original gong-like sounds beyond recognition. The results were recorded as short audio samples which then became the musical source material for the installation as well as the live sound mix for the performance.

Through constant repetition, knitting can be a soothing, meditative activity which often becomes a background to some other action that requires more immediate attention in the foreground. As a parallel, the sound design for BioHome consists of continuously repeated sound patterns that form an audio backdrop for the installation. A patch created in Pd (Fig. 11.3) allows visitors to select a number of sound samples to be looped and played back at varying speeds. These sounds vary in length from half a second to nineteen seconds and include several samples of the gong-like timbre described earlier (labelled A-F in the Pd patch), as well as sounds recorded in a laboratory (autoclave, biohazard bag, centrifuge, etc.). The speed at which these looped sounds are played is determined by sequences of values derived from three knitting patterns (labelled 
'moss', 'herringbone' and 'honey'). Higher values increase the speed of playback, while lower values decrease the speed; negative values reverse the playback of sounds. It is also possible to control the sounds using the two vertical sliders labelled 'modify' and 'volume' in the Pd patch. Through persistent and hypnotic repetition of different audio samples, a pervasive, womb-like ambience is achieved.
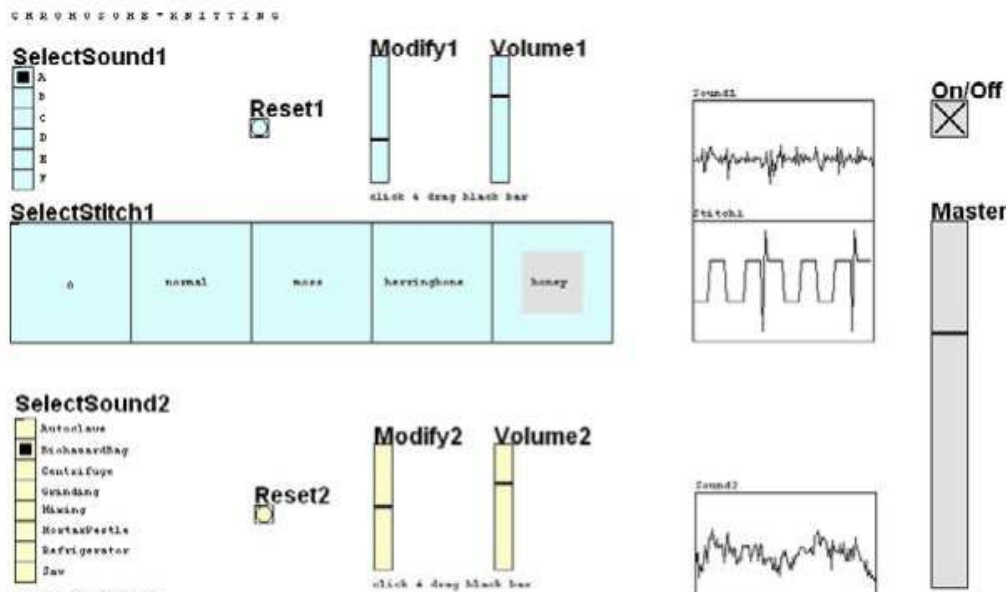

Selectstitch2
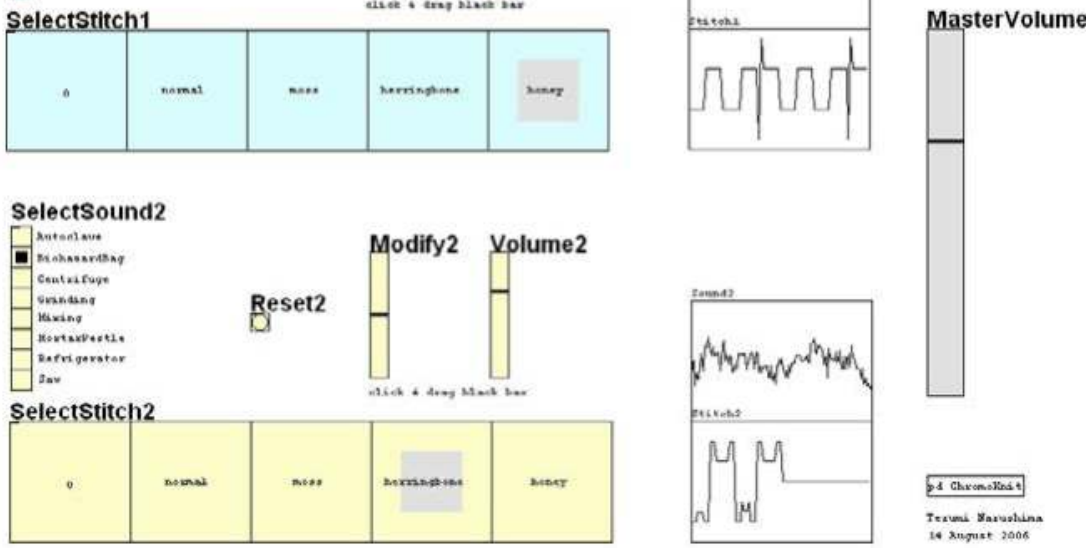

Figure 11.3: Pd patch for BioHome: The Chromosome Knitting Project installation. Courtesy Catherine Fargher and Terumi Narushima.

During the performance, a more elaborate Pd patch than the one shown in Fig. 11.3 is used to select and manipulate various sound loops live. The music is knitted together from multiple strands of sound to create varying textures. Although the music is computer-generated, the sounds have an organic quality that bubbles, splutters and burps. Sometimes it is tongue-in-cheek to complement the humour of the performer's narration; at other times it hints at a darker undertow of unspoken tensions and emotions that are hidden beneath the actor's mask as she switches between different scenes and personas. It is during these transitions that the music is used to innervate the drama and suggest the presence of an inner emotional life, as ambient sounds suddenly jolt into the foreground of the character's consciousness. In this way the soundscape of BioHome aims to create an aesthetic and emotional connection between the 
scientific source material used to build the music and the ethical implications of biotech issues explored in the project as a whole.

\section{Conclusion}

The need for dialogue between scientists and artists, and the differences in culture arising from each discipline, were noted in the landmark publication The Two Cultures: A Second Look (Snow 1964). Here C. P. Snow asserted that the languages and interests of the arts and science communities had created two separate cultures that did not communicate effectively. He also suggested that science equates a body of knowledge with a specific way of learning. Snow stated: "I believe the intellectual life of the whole of western society is increasingly being split into two polar groups, literary intellectuals at one pole, at the other scientists. Their attitudes are so different that [...] they cannot find much common ground" (Snow 1964, 3-4).

Perhaps there are signs that the cultural divisions between art and science are changing as artists seek to engage with current scientific practices that affect the technological and social environment. Art theorist Vibeke Sorenson describes artists as "people who find unusual relationships between events and images"; and "creative inter-disciplinarians" (in Wilson 2002, 35):

Artists are people who create something completely original and new, something beyond known boundaries of the information base. By using or inventing new tools, they show new [...] applications which synergise and synthesise fields. [...] Artists as well as scientists work with abstract symbolic representations for various realities and working tools (in Wilson 2002, 35).

In the case of BioHome, scientific concepts of evolution, mutation and hybridity influenced the form and content of the work. As a hybrid art form the BioHome project hopefully demonstrates Snow's argument that the "clashing point of [...] two disciplines [...] ought to produce creative chances" (Snow 1964, 16), as well as responding to Leonardo Da Vinci's assertion, "for the development of the complete mind: study the science of art and the art of science [...] realise that everything connects to everything else" (in Wallworth 2002, 16). Through an engagement with current scientific and technological concerns, both the BioHome collaborators and other bioartists are developing innovative modes of creative practice as they attempt to find new meanings in the postnatural environment. 


\section{Bibliography}

Braidotti, R. 2002. Metamorphoses. Towards a Materialist Theory of Becoming. Oxford: Polity Press.

Catts, O. and I. Zurr. 2005. Big Pigs, Small Wings: On Genohype and Artistic Autonomy. Culture Machine Journal, Biopolitics issue: n.p. www.culturemachine.net.

Critical Art Ensemble. 2004. The Molecular Invasion. Brooklyn N.Y.: Autonomedia.

Darwin, C. 1985 [1859] The Origin OfSpecies Or The Preservation OfFavoured Races In The Struggle For Life. London: Penguin Books.

Dunn, J. and M. A. Clark. 1999. 'Life Music': The Sonification of Proteins. Leonardo 32(1): $25-32$.

Fargher, C. 2005. Bio-Art: Adventures in ethics. Realtime 65(17). www.realtimearts.net. Franklin, S. 2001. Culturing biology: cell lines for the second millennium. Health 5(3): $335-54$.

Franklin, S., J. Stacey, and C. Lury. 2000. Global Nature, Global Culture. London: SAGE. Gessert, G. 2003. Notes on the art of plant breeding. In L'art Biotech, ed. J. Hauser. Exhibition catalogue.

Grosz, E. 2005. In the Nick of Time: Politics, Evolution and The Untimely. Sydney: Allen and Unwin.

Lister, M., J. Dovey, S. Giddings, I. Grant, and K. Kelly. 2003. New Media: A Critical Introduction. New York: Routledge.

Munster, A. 2005. Why is Bio-art not Bioterrorism? Some Notes in the Networks of Informatic Life. Culture Machine Journal 7, Biopolitics Issue: n.p. www.culture machine.net.

Plant, S. 2003. Mobile Knitting. In Information is Alive, ed. A. Mulder and J. Brouwer. Rotterdam: V2 publishing.

Propp, V. 1984. History and Theory of Folklore. Manchester: Manchester University Press. Shorter Oxford Dictionary, ed. Brown, L. 1993. Oxford: Oxford University Press.

Snow, C. P. 1964. The Two Cultures: And a Second Look. New York: Cambridge University Press.

Waldby, C. 2002. The instruments of life: Frankenstein and Cyberculture, eds. D. Tofts, A. Johnson, and A. Cavallaro. Prefiguring Cyberculture: an Intellectual History. Cambridge, MA: MIT Press.

Wallace, L. 1998. Embodying the Information Age. Sydney: Australia Council for the Arts. Wallworth, L. 2002. Paths to Convergence. Converge: Where Art and Science Meet- 2002 Biennial of Australian Art. Adelaide: Art Gallery of South Australia.

Wilson, S. 2002. Information Arts: Intersections of Art, Science and Technology. Cambridge MA and London: MIT Press. 


\section{On the Contributors}

Trish Adams is a Postdoctoral Research Fellow at the RMIT University, School of Arts, in Melbourne. She has explored the impact of experimental techniques in biomedical engineering on expressions of corporeality. She was among the first artists to personalise her engagement with the scientific data by taking the source material from her own body in the form of unscreened stem cells from her blood. Her research poses questions about what it means to be human in the twenty-first century, and the ways in which our understanding of ourselves may be changed by contemporary biotechnical developments. Adams has presented her work at conferences such as New Constellations: Art, Science \& Society, Sydney 2006; Perth Digital Art \& Culture Conference 2007; ISEA 2008; and Eye of the Storm at Tate Britain 2009.

Rosi Braidotti is a Distinguished Professor in the Humanities at Utrecht University (Netherlands), founding director of the Centre for Humanities, and Honorary Visiting Professor in the Law School at Birkbeck College, London University (England). She has published extensively in feminist philosophy, epistemology, poststructuralism and psychoanalysis. Her books include Patterns of Dissonance (Polity Press 1991); Nomadic Subjects: Embodiment and Sexual Difference in Contemporary Feminist Theory (Columbia University Press 1994); Metamorphoses: Towards a Materialist Theory of Becoming (Polity Press 2002); and Transpositions. On Nomadic Ethics (Polity Press 2006). Her latest book is La Philosophie: là où on ne l'attend pas (Larousse 2009). See: www.let.uu. $\mathrm{nl} / \sim$ Rosi.Braidotti/personal/ and www.hum.uu.nl/cfh.

Michel van Dartel is curator and project manager at V2_, Institute for the Unstable Media in Rotterdam (Netherlands). As a curator he coordinates the events series Test_Lab, a demonstration and discussion platform for artistic research and development. He organises various other national and international electronic art events, ranging from workshops to exhibitions. As project manager he mediates between artists and technicians in artistic productions. 
Prior to his current appointments, he worked as a cognitive scientist at Maastricht University, where he investigated knowledge representation in robot models. Van Dartel holds an MSc in Cognitive Psychology and a PhD in Artificial Intelligence.

Catherine Fargher is an Australian performer, writer and teacher working in radio, contemporary performance, new media/hybrid arts, puppetry, film and theatre. In 2002 she was funded by the Australia Council New Media Fund for the Motherload project, exploring genetic science and human reproductive futures. She has recently completed a Doctorate of Creative Arts at Wollongong University, developing performance texts from bio-ethical fables. Her bio-ethical fable Dr Egg and the Man with No Ear was adapted for new a media/puppetry production at the Sydney Opera House in July 2007 and toured to Chicago in 2008, with proposed tours of Canada, Cyprus and New York in 2010. She is currently working as a lecturer in screen and stage writing at Wollongong University and writing a graphic novel.

Aline Ferreira is an Associate Professor of English at the University of Aveiro (Portugal). Her main interests include the intersections between literature and science as well as literature and the visual arts, feminist utopias and women's studies. Her book I Am the Other: Literary Negotiations of Human Cloning was published by Greenwood Press in 2005. Recent publications comprise articles on feminist utopias, eugenics, biotechnological dystopias and the Luso-British artist Paula Rego. Recent examples include "The Sexual Politics of Ectogenesis in the Today and Tomorrow Series". Interdisciplinary Science Review (March 2009), and "Primate Tales: Interspecies Pregnancy and Chimerical Beings". Science Fiction Studies (July 2008).

Paolo Granata teaches at the Post-Graduate Specialisation School for Art and Historic Heritage at the University of Bologna (Italy). In 2003 he founded the MultiLab educational laboratories on Humanistic Computing for the University of Bologna. Since 2005 he has worked for the research programme on the Italian Videoart Yearbook L'annuario della videoarte italiana. His books include Arte in Rete (2001), the first rational guide on the art resources on the web published in Italy; and Arte, estetica e nuovi media (2009).

Edyta Magdalena Just holds degrees in Political Sciences (Master) and Gender Studies (PhD). She is an affiliated researcher with Gender Studies at the Department of Media and Culture Studies and the Graduate Gender Programme of the Faculty of Humanities of Utrecht University (Netherlands). Her professional profile can be described as cultural studies of science and technology, with a 
strong interest in the epistemological and ethical implications of technologies and visualization techniques. Furthermore, her field of expertise also includes Ethics and Political Sciences.

Matteo Merzagora is scientific director of the TRACES think-tank in Paris (France). He teaches at the Master in Science Communication, SISSA (Trieste, Italy), and lectures for the École Normale Supérieure de Paris, Université Paris Diderot. He works as a consultant for science museums, and as project manager and consultant for European science in society projects. Among his latest books are Science in radio broadcasting (Polimetrica 2005, with E. Tola and M. Mazzonetto), La scienza in mostra (Bruno Mondadori 2007, with P. Rodari), and Scienza da vedere (Sironi 2006), which reviews and discusses the representations of science and scientists in fiction film.

Terumi Narushima is an Australian composer who writes instrumental as well as electronic music. She completed her undergraduate degree at the University of Sydney and obtained a Master of Music (Composition) from Sydney Conservatorium in 2003. Her compositions have been performed in concerts broadcast on Australian radio and she has also worked as a sound designer/ composer for experimental short films which have been screened at festivals in Australia and overseas. She is currently doing a $\mathrm{PhD}$ in Music, and is a part time lecturer in composition, both at the University of Wollongong.

Katia Pizzi is senior lecturer in Italian Studies at the Institute of Germanic \& Romance Studies, School of Advanced Study, University of London (England). She is a graduate of the Universities of Bologna and Cambridge. She has published extensively on the history and culture of the northeastern borders of Italy, children's literature and illustration and modern Italian literary and visual culture, especially the Futurist avant-garde. Her published volumes include $A$ City in Search of an Author: The Literary Identity of Trieste (2001) and Trieste: italianità triestinità e male di frontiera (2007).

Anneke Smelik is professor of Visual Culture, holding the Katrien van Munster chair at the Radboud University of Nijmegen (Netherlands). She recently coedited Technologies of Memory in the Arts (Palgrave 2009); Bits of Life. Feminist Studies of Media, Biocultures, and Technoscience (University of Washington 2007), and Stof en As (Van Gennep 2006), a Dutch book on art and popular culture after September 11. Her research interests include digital art and culture, the performance of authenticity in fashion, and multimedia literacy. Since 2008 she is project leader of the research project "Dutch Fashion Identity in a Glo- 
balised World", funded by the Netherlands Organisation of Scientific Research. See www.annekesmelik.nl

Robert Zwijnenberg is professor of art history in relation to the development of science and technology at Leiden University (Netherlands). His books include The Writings and Drawings of Leonardo da Vinci. Order and Chaos in Early Modern Thought, 1999; the co-edited volume Compelling Visuality. Works of art in and out history, 2003; and the preface to Ingeborg Reichle's Art in the Age of Technoscience. Genetic Engineering, Robotics, and Artificial Life in Contemporary Art, 2009. Zwijnenberg is one of the founding directors of The Arts and Genomics Centre that has the objective of stimulating, initiating and supervising meetings, discussions, collaborations and exchanges between international artists, life science researchers, and professionals from business and government organizations (www.artsgenomics.org). 